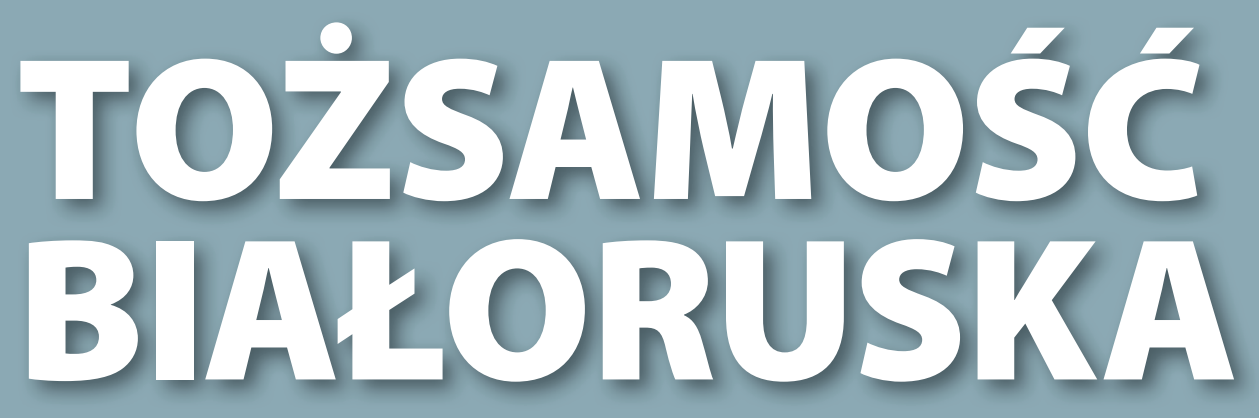

doświadczenia przeszłości

\title{
i wyzwania teraźniejszości
}

W 30. rocznicę uzyskania przez Białoruś niepodległości

Redakcja naukowa

Joanna Getka

Jerzy Grzybowski

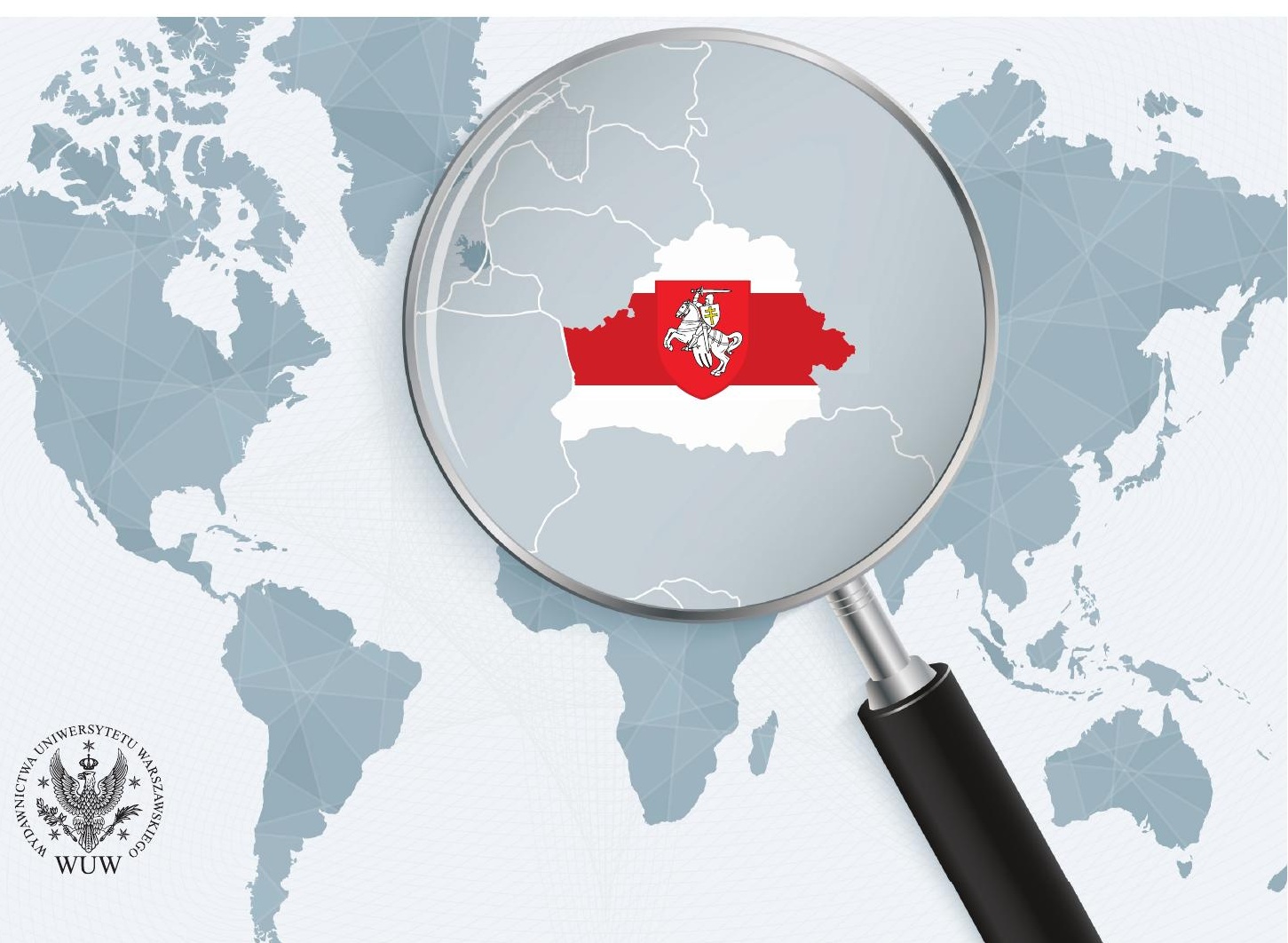




\section{TOŻSAMOŚĆ BIAtORUSKA}

doświadczenia przeszłości

i wyzwania teraźniejszości 
Seria monografii naukowych

INTERKULTUROWOŚĆ EUROPY ŚRODKOWO-WSCHODNIEJ

pod redakcją prof. Joanny Getki 


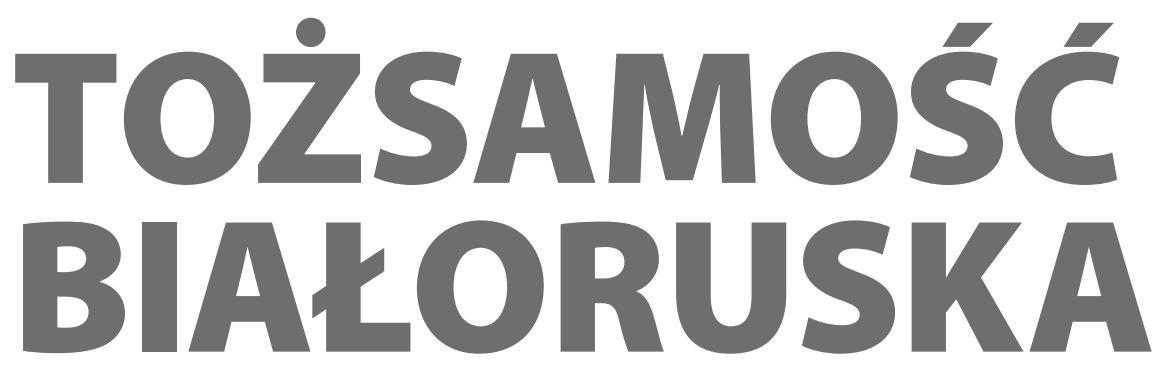

doświadczenia przeszłości

i wyzwania teraźniejszości

W 30. rocznicę uzyskania przez Białoruś niepodległości

Redakcja naukowa

Joanna Getka

Jerzy Grzybowski 
Recenzenci

Andrii Smyrnov

Viktor Moisiienko

Redaktor prowadzący

Jakub Ozimek

Redakcja tekstów polskich

Sebastian Samorek

Korekta tekstów polskich

Klaudia Tworek

Redakcja i korekta tekstów białoruskich

Witalis Łuba

Projekt okładki i stron tytułowych

Anna Gogolewska

Ilustracja na okładce

BOLDG/shutterstock

karnoff/shutterstock

Skład i łamanie

Dariusz Górski

Publikacja dofinansowana przez Uniwersytet Warszawski w ramach Programu Wsparcia Działalności Publikacyjnej Pracowników Uczelni

(c) Copyright by Wydawnictwa Uniwersytetu Warszawskiego, Warszawa 2021

Joanna Getka, Uniwersytet Warszawski, ORCID 0000-0001-5857-7257

Jerzy Grzybowski, Uniwersytet Warszawski, ORCID 0000-0002-7359-487X

ISBN 978-83-235-5290-1 (druk) ISBN 978-83-235-5298-7 (pdf online)

ISBN 978-83-235-5306-9 (e-pub) ISBN 978-83-235-5314-4 (mobi)

Wydawnictwa Uniwersytetu Warszawskiego

00-838 Warszawa, ul. Prosta 69

e-mail:wuw@uw.edu.pl

księgarnia internetowa: www.wuw.pl

Wydanie 1, Warszawa 2021

Druk i oprawa

POZKAL 


\section{Spis treści}

\section{PRZEDMOWY}

Івонка Сурвіла, Старшыня Рады Беларускай Народнай Рэспублікі .. . 9

Iwonka Surwiła, Przewodnicząca Rady Białoruskiej Republiki Ludowej . . . 11

Пётра Мурзёнак, Старшыня Беларускага інстытуту навукі і мастацтва ў Канадзе . . . . . . . . . . . . . . . . . . . . . . . . . . 13

Piotra Murzionak, Prezes Białoruskiego Instytutu Nauki i Sztuki w Kanadzie 15

Захар Шыбека, Прафесар Тэль-Авіўскага ўніверсітэта . . . . . . . . . . . . 17

Zachar Szybieka, Profesor Uniwersytetu w Tel-Awiwie . . . . . . . . . . . . 19

Wstęp . . . . . . . . . . . . . . . . . . . . . . . . . . . . . 21

\section{CZESŚ́ I \\ BIAŁORUSKIE ODRODZENIE NARODOWE: IDEE A RZECZYWISTOŚĆ}

Antoni Mironowicz, Wpływ wyznań religijnych na kształtowanie się białoruskiej świadomości narodowej w XIX wieku . . . . . . . . . . . . . . .

Вячаслаў Швед, Францішак Багушэвіч - igэолаг беларускай нацыянальнай іgэі? . . . . . . . . . . . . . . . . . . . . . . . . . . .

Віктар Корбут, Аgлюстраванне месца і ролі беларускай мовы ў сістэме аgукацыі як фактару фарміравання нацыянальнай igэнтычнасці у публіцыстыцы газеты "Nasza Niwa" ("Наша Нива”) у 19061907 zagax . . . . . . . . . . . . . . . . . . . . . . . . . . . .

Аляксандр Гужалоўскі, Фармаванне беларускага пантэона ў перыяg хрушчоўскай аgлігі 
Jerzy Grzybowski, Uwarunkowania społeczno-polityczne i kulturowe życia narodowego Białorusinów w Łatgalii podczas okupacji niemieckiej (1941-1944) . . . . . . . . . . . . . . . . . .

$$
\begin{gathered}
\text { CZEEŚĆ II } \\
\text { KULTUROWE WYZWANIA TOŻSAMOŚCI BIAŁORUSKIEJ }
\end{gathered}
$$

Наталля Гардзіенка, Дзейнасць Беларускага інстытуту навукі і мастацтва (Нью-Ёрк) па захаванні і пашырэнні беларускай нацыянальнай іяэнтычнасці . . . . . . . . . . . . . . . . . . .

Сяргей Шабельцаў, Беларуская культура як элемент беларускай igэнтыфікацыі імігрантаў у Аргенціне. . . . . . . . . . . . . . . . . . . . . 138

Radosław Kaleta, Język białoruski - stan obecny i perspektywy. . . . . . . 157 Joanna Getka, Мы выйшлі на вуліцу знянацку так... Muzyka jako narzędzie budowania białoruskiej tożsamości oporu . . . . . . . . . . . . . 178

Marianna Julia Koźmińska, Elementy białoruskiej kultury muzycznej jako źródło wiedzy historycznej. . . . . . . . . . . . . . . . . 202

Noty o autorach . . . . . . . . . . . . . . . . . . . . . . . . . . 218 
PRZED M OWY 


\section{Прадмова Івонкі Сурвілы, Старшыні Рады Беларускай Народнай Рэспублікі}

Толькі тая краіна мая,

Што жыць у душы не перастае,

Як свой, без віз адпаведных,

я ўваходжу ў яе.

яна бачыць мяне ў бядзе,

у адчаі, у галечы,

яна мяне спаць кладзе

І духмяным каменем

Мае акрывае плечы.

Марк Шагал

(пераклаg Рыгора Бараgуліна)

- На радзіме і дождж сушэйшы...

Васіль Быкаў

Кожны чалавек носіць у сэрцы скарб у форме пачуцця прыналежнасці да зямлі, якую яму перадалі продкі, нават калі не заўсёды адчувае, што гэта падмурак яго ідэнтычнасці. Гэты скарб яднае яго з іншымі людзьмі тае зямлі, разам яны ствараюць народ. Аднак беларуская ідэнтычнасць - на маю думку - крыху больш складаная. Яна нешта ў родзе дацкага легендарнага героя Холгер Данске, якога каменная постаць сядзіць у падвалах замка ў Хельсінгёр, ды ў выпадку бяды, устае са свайго трону ды ідзе бараніць свой народ.

2020 год даказаў, што народ наш таксама мае сваю нябачную зброю, наш глыбока засакрэчаны патрыятызм, які і з'яўляецца нашай сілай, нашым беларускім Холгер Данске. На працягу стагоддзяў ён праяўляўся, калі народ 
адчуваў пагрозу. Як інакш вытлумачыць наша дзесяцівяковае існаванне, часам у найгоршых умовах? Дзесяць стагоддзяў войнаў і высілкаў ворагаў, каб сцерці нас з паверхні зямлі, не перамаглі нас. Нават пад назовам тутэйшыя, мы ведалі хто мы ёсць.

Народ жыве, яшчэ ўсё жыве, як гэта яскрава даказаў у 2020 годзе. Як той Холгер, наша любоў да Бацькаўшчыны, наша пачуццё прыналежнасці да беларускае зямлі - якую я назвала б галоўнай рысай нашай ідэнтычнасці аказалася мацнейшай за страх і даказала свету, што мы народ годны і жыццяздольны, і што мы заслугоўваем на волю, якую тыран стараецца ад нас адабраць. 3 захапленнем свет глядзеў на нашу смеласць і адначасна лагоднасць, на гераізм пад ботам зверскага ўзурпатара.

Але гэты скарб, які мы перахоўваем стагоддзямі не зваліўся з неба. Ён быў нашай зброяй і нашай сілай, калі ў шасцідзясятыя гады дзевятнаццатага стагоддзя наш народ пайшоў за Кастусём Каліноўскім вызваляць наш край ад "маскалёў". Адчулі мы яго асабліва яскрава ў 1918 годзе, калі Рада Беларускай Народнай Рэспублікі абвясціла свету, што народ наш скінуў ярмо царызму, і зноў у 1920 годзе, калі Случчакі пайшлі "ўміраць, каб жыла Бацькаўшчына".

Паводле майго ўласнага доўгага дасведчання на чужыне, найлепш сведчыла да 2020 года пра беларускую ідэнтычнасць наша эміграцыя. Усім Вам вядомыя словы Адама Міцкевіча: “Літва, мая айчына, толькі той ведае колькі Цябе любіць, хто Цябе страціў”. Гэта перажываюць яшчэ ўсё шматлікія беларусы замежжа. На чужыне яны адчуваюць тугу па Бацькаўшчыне. Людзі, якія ў Беларусі не размаўлялі па-беларуску, раптоўна адкрываюць у сэрцы бязмежную любоў да свае мовы, да свае зямлі, становяцца беларускімі патрыётамі. Свет без Беларусі траціць для іх свой сэнс, часта ператвараецца ў пустыню. Пачуццё прыналежнасці да сваёй зямлі робіцца штораз мацнейшым, дае ім новыя сілы. Яны ўжо не патрабуюць дапасоўвацца да суседняй ментальнасці. Раптам ганарацца быць беларусамі і выступаюць пад бел-чырвона-белым сцягам у абарону свайго народа. Яны здаюць сабе справу, як іхняя любоў да Бацькаўшчыны дапамагае ім стацца паўнавартаснымі людзьмі. Іх жыццё напаўняецца багацтвам, пра якое яны дасюль і не марылі, стараючыся пад уплывам суседзяў дапасавацца да чужых каштоўнасцей. Не дарэмна акупанты робяць велізарныя высілкі, каб выкараніць у нас нашу ідэнтычнасць ды замяніць яе сваёю.

Дзякаваць Богу, беларуская ідэнтычнасць за глыбокая, каб хтось мог яе выкараніць. Яна заўсёды застанецца той унутранай сілай, якая нас будзе берагчы да канчатковай перамогі ў змаганні за свабоду і незалежнасць. 


\title{
Przedmowa Iwonki Surwity, Przewodniczącej Rady Białoruskiej Republiki Ludowej
}

\author{
Tylko ten kraj jest mój, \\ Który nie przestaje żyć w duszy, \\ Do którego bezwizowo \\ Ja wchodzę. \\ On widzi mnie w biedzie, \\ W rozpaczy, w ubóstwie, \\ On usypia mnie \\ I pachnącym kamieniem \\ Moje ramiona otula.
}

Marc Chagall

- W domu nawet deszcz jest bardziej suchy...

Wasil Bykau

Każdy nosi w sercu skarb w postaci poczucia przynależności do ziemi danej mu przez przodków, nawet jeśli nie zawsze czuje, że to jest jego tożsamość. Ten skarb łączy go z innymi mieszkańcami tej ziemi, z którymi tworzy naród. Jednak tożsamość białoruska jest - moim zdaniem - trochę bardziej złożona. To tak jak Ogier Duńczyk (legendarny bohater narodowy Danii, po duńsku Holger Danske) - siedzi w podziemiach zamku w Helsingorze, ale w razie kłopotów wstaje $z$ tronu i idzie bronić swego ludu.

Rok 2020 dowiódł, że nasz naród też ma swoją niewidzialną broń, nasz głęboko skryty patriotyzm, który jest naszą siłą, naszym białoruskim Ogierem Duńczykiem. Od wieków ta siła objawiała się wtedy, gdy ludzie czuli się zagrożeni. Jak inaczej wytłumaczyć naszą tysiącletnią egzystencję, czasami w najgorszych warunkach? Dziesięć wieków wojen i wysiłków wrogów, aby zmieść nas z powierzchni ziemi, nie pokonało nas. Nawet wtedy, gdy nazywano nas „tutejszymi”, wiedzieliśmy, kim jesteśmy. 
Naród wciąż żyje, co zostało wyraźnie udowodnione w 2020 roku. Tak jak we wspomnianej legendzie o Holgerze Danske - nasza miłość do Ojczyzny, nasze poczucie przynależności do ziemi białoruskiej, którą nazwałabym główną cechą naszej tożsamości, okazały się silniejsze od strachu i pokazały światu, że jesteśmy narodem godnym, który zasługuje na wolność, chociaż tyran próbuje ją nam odebrać. Świat z podziwem patrzył na naszą odwagę i zarazem dobroć, na bohaterstwo pod butem brutalnego uzurpatora.

Ten skarb, który ukrywaliśmy od wieków, nie spadł jednak z nieba. Był naszą bronią i naszą siłą w latach sześćdziesiątych XIX wieku, kiedy nasz naród poszedł za Konstantym Kalinowskim, aby wyzwolić nasz kraj od „Moskali”. Szczególnie dotkliwie odczuliśmy to w 1918 roku, kiedy Rada Białoruskiej Republiki Ludowej ogłosiła światu, że nasz naród zrzucił jarzmo caratu i ponownie w 1920 roku, kiedy powstańcy słuccy poszli „umrzeć, aby Ojczyzna mogła żyć”.

Z moich wieloletnich obserwacji wynika, że nasza diaspora była najlepszym dowodem trwałości tożsamości białoruskiej do 2020 roku. Wszyscy znają słowa Adama Mickiewicza: „Litwo, Ojczyzno moja! ty jesteś jak zdrowie; ile cię trzeba cenić, ten tylko się dowie, kto cię stracił”. Wciąż tego uczucia doświadcza wielu Białorusinów za granicą. Na obczyźnie tęsknią za domem. Ludzie, którzy nie mówili po białorusku na Białorusi, nagle zaczęli otwierać swoje serca na bezgraniczną miłość do swojego języka, do swojej ziemi, i zostali patriotami. Świat bez Białorusi stracił dla nich sens, często zamieniając się w pustkę. Poczucie przynależności do swojej ziemi staje się coraz silniejsze, daje im nową siłę. Nie potrzebują już dostosowania się do mentalności sąsiadów. Nagle stają się dumni z tego, że są Białorusinami i stają pod biało-czerwono-białą flagą w obronie swojego narodu. Oni zdają sobie sprawę z tego, jak miłość do Ojczyzny pomaga im stać się pełnoprawnymi ludźmi. Ich życie wypełnia się bogactwem, o którym jeszcze nie marzyli, próbując pod wpływem sąsiadów dostosować się do wartości innych ludzi. Nic dziwnego, że okupanci dokładali wszelkich starań, aby wykorzenić naszą tożsamość i zastąpić ją ich własną.

Dzięki Bogu tożsamość białoruska jest tak głęboka, że nikt nie może jej wykorzenić. Zawsze pozostanie wewnętrzną siłą, która będzie nas chronić, aż do ostatecznego zwycięstwa w walce o wolność i niepodległość. 


\section{Прадмова Пётры Мурзёнка, Старшыні Беларускага інстытуту навукі і мастацтва ў Канадзе}

Праблемы нацыянальнай ідэнтычнасці беларусаў былі і ёсць актуальнымі. Яны і будуць актуальнымі да той пары, пакуль можна будзе сказаць: так, беларуская нацыя уссталявалася, усталявалася ў вольнай дзяржаве, незалежнай ад еўразійскай цывілізацыі, пазбавіўшыся дыктатуры і знайшоўшы свой правільны шлях у сусвеце.

Пытанне нацыянальнай ідэнтыфікацыі - ключавое для рэалізацыі нацыянальнай ідэі, канчатковым прадуктам якой і ёсць нацыянальная дзяржава. Пасля некалькіх істотных параз, звязаных з будаўніцтвам нацыянальнай дзяржавы ў XX стагоддзі, беларускае грамадства ўсё яшчэ мае запыт на кансалідацыю, і, хачу падкрэсліць, не кароткачасовую, а доўгатэрміновую стратэгічную кансалідацыю розных яго слаёў, уключаючы навуковую супольнасць. Бо кансалідацыя палітычная ў стаўленні да будаўніцтва нацыі ў значнай ступені не была рэалізавана як мінулай, так і сучаснай нацыянальна-свядомай элітай і ў асноўным па прычыне палітычнай блізарукасці, адсутнасці як адзінства, так і выпрацаванай стратэгіi, а не толькі па прычыне рэпрэсіўнага ўплыву дыктатарскага рэжыму.

Калі праводзіць гістарычныя паралелі, то ў параўнанні з нашымі самымі блізкімі суседзямі, Беларусь адстае ў сваім нацыянальным развіцці. Гэта яскрава заўважна, калі зазірнуць на пачатак і на канец мінулага стагоддзя. Так, высілкі Іосіфа Пілсудскага, польскай эліты, а таксама Літоўскай Тарыбы скончыліся станаўленнем Польскай і Літоўскай дзяржаў; актыўнасць нацыянальных эліт вывела гэтыя краіны за межы ўплыву СССР-Расіі і далучыла іх у ЕС і НАТО. Ні таго, ні другога нацыянальна-свядомыя сілы у Беларусі не асягнулі - не маем асноўнага - па-сапраўднаму незалежнай нацыянальнай дзяржавы. Прычын таму шмат. Асабліва гэта заўважна сёння - падчас Рэвалюцыі надзеі, як я яе называю. Адной з такіх прычын 
з'яўляецца тое, што беларусам пастаянна не стае волі і кансалідуючага цэнтра, які б мог стратэгічна вызначыць шлях, па якім Беларусь магла б вызваліцца з-пад імперскіх аковаў суседа і з-пад савецкага мінулага, якім кіруецца дыктатар Лукашэнка.

Праграма канферэнцыі прадугледжвае разгляд пытанняў ідэнтыфікацыі беларусаў у тых ці іншых краінах як сёння, так і ў мінулым. Відавочна, што праблема самаідэнтыфікацыі беларускіх эмігрантаў, улічваючы асіміляцыю з насельніцтвам краіны пражывання і іх канчатковае рашэнне эміграваць па той ці іншай прычыне, значна больш складанае, чым тая ж праблема на радзіме. Было б таксама цікава параўнаць і ацаніць магчымы ўплыў дыяспары і саміх працэсаў ідэнтыфікацыі на сітуацыю ў Беларусі да Рэвалюцыі надзеі, і цяпер, калі яна распачалася і працягваецца.

Было б цудоўна, калі б у выніку кансалідаванай навуковай думкі на сённяшняй канферэнцыі можна было атрымаць такія рэцэпты, якія 6 дапамаглі беларусам, 84,9\% якіх вызначаюць сябе беларусамі на радзіме, прыйсці да разумення сапраўднай, глыбіннай, існай нацыянальнай ідэнтыфікацыі, вырвацца з імперыі зла і выплысці ў добрым нацыянальным здароўі на бераг дэмакратыі, жыцця і гуманізму. Амаль 70 гадоў таму Чэслаў Мілаш пісаў пра характар дзеяў нацыянальных сіл ва ўмовах дыктатуры. 3 таго часу ў яго краіне і у нашых суседзяў шмат чаго змянілася ў пазітыўным кірунку. На шляху да прагрэсу знаходзіцца Украіна, якую я кваліфікую як нашага суседа па заходнерутэнскай цывілізацыі. Веру, што надзея на свой шлях застаецца і для Беларусі.

Атава, 1 красавіка 2021 гоgа 


\section{Przedmowa Piotry Murzionaka, Prezesa Białoruskiego Instytutu Nauki i Sztuki w Kanadzie}

Problem tożsamości narodowej Białorusinów był i nadal jest aktualny. Nie straci on na aktualności, dopóki naród białoruski nie uwolni się od cywilizacji eurazjatyckiej, pozbywając się dyktatury i odnajdując właściwą drogę w świecie.

Kwestia identyfikacji narodowej jest kluczem do realizacji idei narodowej, której ostatecznym wynikiem jest państwo narodowe. Po kilku znaczących porażkach w budowaniu narodu w XX wieku społeczeństwo białoruskie wciąż potrzebuje konsolidacji. Chcę podkreślić, że nie chodzi tu o zjednoczenie krótkoterminowe, lecz o długofalową strategiczną konsolidację różnych warstw, w tym naukowców. Konsolidacja polityczna w odniesieniu do budowania narodu w dużej mierze nie została zrealizowana zarówno przez dawne, jak i obecne elity białoruskie - i to głównie z powodu politycznej krótkowzroczności, braku jedności i strategii, a nie tylko z powodu represji dyktatury.

Jeśli poszukamy analogii w historii, to zrozumiemy, że w porównaniu z najbliższymi sąsiadami Białoruś pozostaje w tyle rozwoju narodowego. Widać to wyraźnie na podstawie wydarzeń na początku i końcu ubiegłego wieku. Starania Józefa Piłsudskiego i elit polskich oraz litewskiej Taryby zakończyły się utworzeniem państw polskiego i litewskiego. Działalność elit narodowych wyprowadziła te państwa poza wpływy ZSRR i Rosji oraz włączyła je do UE i NATO. Tymczasem na Białorusi żadne uświadomione narodowo elity nie zdołały zbudować prawdziwie niezależnego państwa narodowego. Jest to szczególnie widoczne dzisiaj - w czasie Rewolucji Nadziei, jak ją nazywam. Powodów jest wiele - jednym z nich jest to, że Białorusinom ciągle brakuje woli i konsolidacyjnego centrum, aby strategicznie określić sposób, w jaki Białoruś mogłaby uwolnić się z imperialnych kajdan sąsiada i sowieckiej przeszłości promowanej przez dyktatora Łukaszenkę.

Jest oczywiste, że problem samoidentyfikacji białoruskich emigrantów, biorąc pod uwagę asymilację z ludnością ich kraju zamieszkania i powód ich 
ostatecznej decyzji o emigracji, jest znacznie bardziej skomplikowany niż ten sam problem w kraju. Dlatego interesujące byłoby porównanie i ocena możliwego wpływu diaspory i procesów identyfikacyjnych na sytuację na Białorusi zarówno przed Rewolucją Nadziei, jak i teraz, gdy ona trwa.

Byłoby wspaniale, gdyby w wyniku ugruntowanej myśli naukowej udało się znaleźć dla Białorusinów sposób, który umożliwiłby im zrozumienie, czym jest prawdziwa i głęboka tożsamość narodowa (84,9\% obywateli Białorusi deklaruje narodowość białoruską) i pomógł im wyrwać się z imperialnych szponów, aby popłynąć w dobrym zdrowiu narodowym do brzegów demokracji, życia i humanizmu. Niemal 70 lat temu Czesław Miłosz pisał o charakterze działań sił narodowych pod dyktaturą. Od tego czasu wiele zmieniło się na korzyść w jego kraju i u naszych sąsiadów. Na drodze do postępu znajduje się Ukraina, którą uważam za naszego sąsiada z kręgu cywilizacji zachodnioruskiej. Wierzę, że jest nadzieja, iż Białoruś także znajdzie własną drogę. 


\section{Прадмова Захара Шыбекі, Прафесара Тэль-Авіўскага ўніверсітэта}

Празмерна рад, што маю магчымасць вітаць вас з Ізраіля. Грамадзяне гэтай краіны, выхадцы з Беларусі, адзінадушна прынялі сцяг і герб БНР. Яны вельмі актыўна падтрымліваюць перамены на сваёй радзіме. У вывучэнні эвалюцыі самаідэнтыфікацыі беларусаў, безумоўна, павінна ўлічвацца яўрэйская прысутнасць. Супольнасць беларускіх яўрэяў у Ізраілі - гэта важны рэсурс для рамонту разбуранага беларускага дома. Вядома, што дзеячы БНР пастаянна імкнуліся ангажаваць яўрэяў у беларускія справы.

Пытанне нацыянальнай ідэнтычнасці беларусаў займае вельмі важкае месца ў даследаваннях над гісторыяй беларускага народа. Гісторыкі ў стане не толькі вывучаць эвалюцыю самаідэнтыфікацыі жыхароў Беларусі, але і практычна ўмацаваць іх знітаванне. Па-першае, гісторыкам пад сілу разбурыць беларускі сіндром непазбежнай залежнасці ад Расіi, каб зрабіць беларусаў вольнымі грамадзянамі. Гісторыя беларуска-расійскіх адносін сведчыць, што беларусы лёгка купляліся на салодкія абяцанкі Расіi, але потым наступала горкае расчараванне і падман. Па-другое, гісторыкі ўжо падрыхтаваны для стварэння праўдзівых калектыўных прац агульнанацыянальнага маштабу, прызначаных для ўсёй беларускай нацыі. I не толькі. Еўрапейская грамадскасць, заінтрыгаваная падзеямі ў сучаснай Беларусі, ужо падрыхтаваная да зацікаўленага азнаямлення з яе гісторыяй. Застаецца толькі перакласці нашу гісторыю на мовы еўрапейскіх народаў, каб яны больш глыбока і рэальна зразумелі заканамерную тэндэнцыю вяртання беларусаў у еўрапейскую супольнасць. Таму я вітаю ідэю выдання калектыўнай працы Беларуская igэнтычнасць: gосвеg мінулага і выклікі сучаснасці, якая з'яўляецца плёнам працы даследчыкаў: айчынных і замежных беларусістаў. 
Выданне гэтай калектыўнай манаграфіі з'яўляецца вельмі своечасовым, калі пытанне беларускай ідэнтычнасці ўваходзіць у наступную фазу свайго развіцця і набывае новае вымярэнне. На пераломе эпох у Беларусі жыць балюча, але цікава. Бясспрэчна, што нас, гісторыкаў, чакаюць вялікія справы. Вось я і хачу пажадаць нам усім поспехаў! 


\section{Przedmowa Zachara Szybieki, Profesora Uniwersytetu w Tel-Awiwie}

Bardzo się cieszę, że mam okazję powitać Państwa z Izraela. Obywatele tego kraju pochodzący z Białorusi jednogłośnie przyjęli flagę i godło Białoruskiej Republiki Ludowej (BRL). Ci ludzie bardzo aktywnie wspierają przemiany w swojej ojczyźnie. Badania ewolucji samoidentyfikacji Białorusinów muszą również uwzględniać rolę Żydów w dziejach Białorusi. Białoruska społeczność żydowska w Izraelu jest ważnym elementem mogącym wspierać naprawę zniszczonego domu białoruskiego. Jeszcze w czasach BRL społeczność żydowska czynnie uczestniczyła w życiu białoruskim.

Kwestia tożsamości narodowej Białorusinów zajmuje bardzo ważne miejsce w badaniach nad historią narodu białoruskiego. Historycy są w stanie nie tylko badać ewolucję samoidentyfikacji narodu białoruskiego, lecz także ją wzmacniać. Po pierwsze, historycy mogą pomóc społeczeństwu białoruskiemu uwolnić się od syndromu zależności od Rosji i tym samym uczynić Białorusinów wolnymi obywatelami. Historia stosunków białorusko-rosyjskich dowodzi, że Białorusini dawali się uwieść słodkim obietnicom Rosji, lecz potem następowało gorzkie rozczarowanie i zawód. Po drugie, historycy już są przygotowani do tworzenia publikacji, których odbiorcą jest naród białoruski i nie tylko. Współczesne wydarzenia na Białorusi wzbudziły zainteresowanie Europejczyków, którzy też już są gotowi zgłębiać wiedzę na temat historii Białorusi. Musimy tylko przetłumaczyć naszą historię na języki narodów europejskich, żeby one głębiej zrozumiały wszelkie zawiłości związane z powrotem Białorusinów do rodziny europejskiej. W związku z tym z satysfakcją przyjmuję pomysł wydania monografii zbiorowej Tożsamość białoruska: doświadczenia przeszłości i wyzwania teraźniejszości, która jest efektem pracy badaczy zarówno krajowych, jak i zagranicznych. 
Publikacja tej zbiorowej monografii następuje we właściwym momencie, gdy kwestia tożsamości białoruskiej wchodzi w kolejną fazę swojego rozwoju i nabiera nowego wymiaru. Życie na Białorusi na przełomie wieków jest bolesne, ale też interesujące. Nie ulega wątpliwości, że na nas, historyków, czekają wielkie wyzwania. Życzę zatem nam wszystkim sukcesów! 


\section{Wstęp}

W tym roku mija 30 lat od proklamowania niepodległości Białorusi. 25 sierpnia 1991 roku ogłoszono powstanie Republiki Białorusi. Pojawienie się na mapie politycznej świata niezależnego państwa białoruskiego stało się możliwe dzięki rozpadowi Związku Sowieckiego. Białorusinom udało się wybić na niepodległość w sposób bezkrwawy, ponieważ ówczesny system sowiecki był już całkowicie niezdolny do dalszego funkcjonowania. Ta okoliczność przyczyniła się do pojawienia się w latach dziewięćdziesiątych w kraju i za granicą opinii, że wolność Białorusinom niemalże „spadła prosto z nieba”. Pogląd ten jednakże nie znajduje potwierdzenia w faktach. Uważna analiza dramatycznej XX-wiecznej historii Białorusi dowodzi, że idea utworzenia niezależnego państwa narodziła się ponad siedemdziesiąt lat przed proklamowaniem Republiki Białorusi. 25 marca 1918 roku ogłoszono powołanie Białoruskiej Republiki Ludowej. Mimo że państwo to istniało krótko, to jednak odcisnęło trwały ślad na kartach historii Białorusi, torując drogę kolejnym inicjatywom zmierzającym do utworzenia niezależnego państwa białoruskiego. Białoruskie starania niepodległościowe zakończyły się sukcesem po niemal wieku, kiedy wraz z rozpadem ZSRS Białorusini uzyskali kolejną szansę uzyskania niezależnej państwowości. Zarówno proklamowanie BRL, jak i Republiki Białorusi były pokłosiem złożonego procesu kształtowania tożsamości białoruskiej.

W związku z tym warto przyjrzeć się bliżej zagadnieniom związanym z tworzeniem się tożsamości narodowej i kulturowej Białorusinów, a głównym celem niniejszej publikacji jest ukazanie wewnętrznych i zewnętrznych czynników wpływających na jej rozwój. W książce znalazły się zagadnienia związane z różnymi przejawami tego skomplikowanego i wielowymiarowego fenomenu oraz rolą czynników wpływających na kształtowanie takich cech narodowych Białorusinów, jak język, religia, zwyczaje czy pamięć historyczna. Jej autorzy 
omawiają również najważniejsze dylematy i wyzwania, które zaważyły na wyborze cywilizacyjnym narodu białoruskiego.

Autorzy publikowanych w niniejszym tomie artykułów wypełniają pewną lukę zarówno w badaniach nad Białorusią, jak i w świadomości społecznej. Pomimo bliskiego sąsiedztwa wiedza naszego społeczeństwa o Białorusinach i Białorusi nadal jest raczej znikoma, powierzchowna i fragmentaryczna. Zeszłoroczny demokratyczny zryw społeczeństwa, który przez wiele miesięcy przykuwał światową opinię publiczną (wraz z towarzyszącymi mu odniesieniami historycznymi i kulturowymi), spowodował, że zainteresowanie bogatą historią i kulturą naszego wschodniego sąsiada znacznie wzrosło. Nadal jednak niewiele wiemy o białoruskich tradycjach i aspiracjach niepodległościowych. Zbliżająca się 30. rocznica ogłoszenia przez Białoruś niepodległości jest zatem doskonałą okazją do podjęcia głębszej refleksji na temat meandrów trudnego procesu budowania białoruskiej wspólnoty narodowej od momentu narodzin suwerennego państwa u progu XX wieku do chwili obecnej.

Tom ma charakter interdyscyplinarny, a jego autorami są przedstawiciele różnych dyscyplin: historii, kulturoznawstwa, religioznawstwa i językoznawstwa. Tę różnorodność uważamy za jeden z głównych walorów tej publikacji. Naszym zdaniem za sprawą interdyscyplinarności jest możliwe najbardziej wnikliwe i dogłębne przyjrzenie się meandrom białoruskiej tożsamości narodowej, jej sukcesom i klęskom.

W pierwszej części publikacji znalazły się materiały o charakterze historycznym, dotyczące uwarunkowań politycznych i społeczno-kulturowych powstania i rozwoju białoruskiej idei narodowej. Otwiera je tekst Antoniego Mironowicza, który porusza bardzo interesujący, a zarazem szerzej nieznany problem wpływu poszczególnych wyznań religijnych na kształtowanie się białoruskiej tożsamości narodowej w XIX wieku. Autor poddał analizie wpływ prawosławia, protestantyzmu i katolicyzmu obydwu obrządków na kształtowanie odrębności narodowej Białorusinów. Następny tekst, przygotowany przez Viachaslaua Shveda, konkretyzuje zagadnienie białoruskiej idei narodowej i poświęcony jest roli w jej ustalaniu Franciszka Bohuszewicza, jednego z prekursorów białoruskiego odrodzenia narodowego na przełomie XIX i XX wieku. Z innej perspektywy kształtowanie się białoruskiej idei narodowej poruszył Viktar Korbut. Swoją analizę skierował on na rolę języka białoruskiego jako czynnika kształtowania idei białoruskiej na łamach pierwszych periodyków białoruskich „Nasza Dola” i „Nasza Niwa", ukazujących się na początku XX wieku. Aliaksandr Huzhalouski z kolei przedstawił mało znany epizod z dziejów Białorusi, którym jest kształtowanie panteonu białoruskich bohaterów narodowych w okresie odwilży Nikity Chruszczowa. Część pierwszą monografii zamyka tekst Jerzego Grzybowskiego, 
w którym autor przeanalizował uwarunkowania społeczno-polityczne i kulturowe działalności szkolnictwa białoruskiego w Łatgalii podczas okupacji niemieckiej (1941-1944). Badacz ukazał warunki, w których funkcjonowało to szkolnictwo oraz stosunek okupantów niemieckich do poczynań łotewskich Białorusinów.

W drugiej części publikacji autorzy podejmują problematykę tożsamości kulturowej Białorusinów w kraju i za granicą. Natallia Hardzijenka scharakteryzowała wpływ działalności Białoruskiego Instytutu Nauki i Sztuki w Nowym Jorku na zachowanie i ugruntowanie tożsamości narodowej emigrantów białoruskich w Stanach Zjednoczonych po zakończeniu II wojny światowej. Podobny temat omówił również Siarhei Shabeltsau, który przybliżył problem kultury białoruskiej jako czynnika zachowania tożsamości narodowej Białorusinów w Argentynie. Trzy kolejne teksty dotyczą współczesnej problematyki tożsamościowej. Tekst Radosława Kalety poświęcony został językowi białoruskiemu. Autor przedstawił stan obecny tego języka i wyzwania, które na niego czekają w dającej się przewidzieć przyszłości. Tekst Joanny Getki traktuje o muzyce jako narzędziu budowania białoruskiej tożsamości oporu, która się narodziła na fali walki społeczeństwa białoruskiego z autorytarnym reżimem. Tom kończy tekst Marianny Julii Koźmińskiej, która przeanalizowała elementy białoruskiej kultury muzycznej jako źródła wiedzy historycznej.

Wszystkie teksty ukazują różne aspekty białoruskiej tożsamości kulturowej. Część zamieszczonych tu analiz to początek badań naukowych nad problematyką tożsamości białoruskiej w różnych jej przejawach, inne rozważania naukowe stanowią podsumowanie wieloletnich badań. Autorzy szukali odpowiedzi na zasadnicze pytanie: czym jest tożsamość białoruska, w czym ona się przejawia i przed jakimi wyzwaniami stoi obecnie?

Czujemy się również zaszczyceni, że przedmowy do niniejszej publikacji przygotowali: pani przewodnicząca Rady Białoruskiej Republiki Ludowej Iwonka Surwiła, pan dyrektor Białoruskiego Instytutu Nauki i Sztuki w Kanadzie Piotra Murzionak i wybitny znawca historii Białorusi pan profesor Zachar Szybieka.

Redaktorzy 
CZĘŚĆ I

BIAŁORUSKIE ODRODZENIE NARODOWE:

IDEE A RZECZYWISTOŚĆ 


\section{Wpływ wyznań religijnych na kształtowanie się białoruskiej świadomości narodowej w XIX wieku*}

The influence of religious denominations on the formation of the Belarusian national consciousness in the 19th century

In the late 19th century national movements prevailed in the Russian Empire, and nationality and religion converged. In 1897 Russian territories were dominated by the Orthodox population (75\%), which inhabited mainly the European part of Russia and the Siberian regions colonized by the Russians. Orthodoxy was rather weak in the peripheral provinces of the Empire. The Congress Kingdom of Poland was dominated by Catholics, Finland, Estonia and Latvia featured mostly Protestants, while Muslims prevailed in Central Asia. In the 19th century no religion in Belarus was conducive to Belarusian national revival. It is a myth to point to the Uniate Church as a source of national revival. This rite, Latinized in the 18th century, became the object of rivalry between the two main Christian denominations: the Orthodox Church and the Roman Catholic Church. The Russian Orthodox Church, which has been a strong Russification factor on the territory of Belarus, did not foster Belarusian national revival. Even though most of the pioneers of the revival belonged to it, the Catholic Church also did nothing to support the Belarusianization of religious life. Catholicism remained a Polish religion reluctant to Belarusian national ideas. We also have no evidence of any role of Protestant or non-Christian denominations in shaping the Belarusian national movement. Ke y w ords: Orthodox Church, Catholic Church, Belarus, national consciousness

Wpływ wyznań religijnych na kształtowanie się białoruskiej świadomości narodowej w XIX wieku

Pod koniec XIX w. w Imperium Rosyjskim dominowały ruchy narodowe, zbiegały się narodowości i wyznania. W 1897 r. na ziemiach tych dominowała ludność prawosławna (75\%), która zamieszkiwała głównie europejską część Rosji i skolonizowane przez Rosjan rejony syberyjskie. Prawosławie było rzadko spotykane w peryferyjnych prowincjach Cesarstwa. W Królestwie Polskim dominowali

* Prezentowany tekst jest poprawioną wersją artykułu autora Wyznanie a świadomość narodowa Białorusinów, opublikowanego w „Białostockich Tekach Historycznych” 2011, nr 9, s. 81-98. 
katolicy, w Azji Środkowej muzułmanie, najwięcej protestantów było w Finlandii, Estonii i Łotwie. W XIX w. żadna religia na Białorusi nie sprzyjała białoruskiemu odrodzeniu narodowemu. Mitem jest, iż Kościół unicki był źródłem odrodzenia narodowego. Obrządek ten, zlatynizowany w XVIII w., stał się przedmiotem rywalizacji dwóch głównych wyznań chrześcijańskich: prawosławnego i rzymskokatolickiego. Rosyjska Cerkiew Prawosławna - silny czynnik rusyfikacji na terenie Białorusi - nie służyła białoruskiemu odrodzeniu narodowemu. Kościół katolicki nie zrobił nic w sprawie białorutenizacji życia religijnego. Mimo że do tego Kościoła należała większość pionierów białoruskiego odrodzenia narodowego, pozostał religią polską, niechętną białoruskim ideom narodowym. Nie mamy też dowodów na jakąkolwiek rolę wyznań protestanckich lub niechrześcijańskich w kształtowaniu białoruskiego ruchu narodowego.

Słowa kluczowe: Kościół prawosławny, Kościół katolicki, Białoruś, świadomość narodowa

Ukazanie wpływu poszczególnych wyznań na kształtowanie się świadomości narodowej mieszkańców Białorusi w XIX w. nie jest zadaniem łatwym. Zjawiska tego nie można rozpatrywać w oderwaniu od prezentacji ogólnej struktury narodowościowej mieszkańców Rosji. Zdobycze terytorialne Rosji w XVIII i XIX w. spowodowały, że w jej granicach znaleźli się mieszkańcy innych wyznań chrześcijańskich i niechrześcijańskich. W 1796 r. na ogólną liczbę 41,2 mln mieszkańców Imperium Rosjanie stanowili 48,9\%. Oprócz Rosjan w granicach państwa mieszkali Ukraińcy (19,8\%), Białorusini (8,3\%), Polacy $(6,2 \%)$, Tatarzy (2,2\%), Finowie (2,2\%), Litwini (2,0\%), Łotysze (1,7\%), Żydzi (1,4\%), Estończycy (1,2\%), Mordwini $(0,8 \%)$, Czuwasze $(0,8 \%)$, Niemcy $(0,6 \%)$, Baszkirzy $(0,5 \%)$ i inne narodowości (2,9\%). Podział narodowościowy przekładał się na podział wyznaniowy. Wyznawcami prawosławia byli w większości Rosjanie, Ormianie, Białorusini i Ukraińcy. Część Białorusinów i Ukraińców była grekokatolikami, a część Rosjan - staroobrzędowcami. Polacy, Litwini oraz częściowo Niemcy i Ormianie byli wyznania rzymskokatolickiego. Wyznania protestanckie dominowały wśród Łotyszów, części Niemców, Finów i Estończyków. Islam wyznawali Tatarzy i inne ludy w części azjatyckiej Rosji. Judaizm dominował wśród ludności żydowskiej. Pozostałe ludy wyznawały buddyzm, lamaizm i religie pogańskie'.

W 1897 r. na terytorium państwa carów dominowała ludność prawosławna (75\%), zamieszkała głównie w europejskiej części Rosji i na obszarach syberyjskich skolonizowanych przez Rosjan. W peryferyjnych prowincjach Imperium prawosławie było słabo rozpowszechnione. W Królestwie Polskim dominowali

1 В.М. Бабузан, Нароgы России в первой половине XIX в. Численность и этнический состав, Москва 1992, s. 125; P. Eberhardt, Geografia ludności Rosji, Warszawa 2002, s. 87-88. 
katolicy, w Finlandii, Estonii i Łotwie - protestanci, a w Azji Środkowej - muzułmanie. W sumie w Rosji w 1897 r. było 87,1 mln prawosławnych, 11,5 mln katolików, 2,2 mln staroobrzędowców, 1,2 mln wyznawców Cerkwi ormiańskiej, 3,8 mln protestantów, 13,9 mln wyznawców islamu, 5,2 mln wyznawców judaizmu, a 170 tys. buddyzmu i lamaizmu².

Rosyjska Cerkiew Prawosławna była w XIX w. największą wspólnotą wyznaniową na terenie Rosji, Białorusi i Ukrainy33. Za panowania Aleksandra I (18001824) Rosja prowadziła politykę tolerancyjną wobec innowierców. W czasach Mikołaja I Rosja zajęła Azerbejdżan (1828), Besarabię (1829) i znaczne obszary w środkowej Azji z zamieszkałą tam ludnością niechrześcijańską. Carat, w celu zapewnienia sobie poparcia ludności rosyjskiej, popierał ideologię państwa prawosławnego opartego na symbiozie „prawosławia, samowładztwa i narodowości”. W odróżnieniu od poprzednika car Mikołaj I wspierał tendencje integrystyczne w Cerkwi prawosławnej. W II połowie XIX stulecia zaczęły się kształtować ruchy narodowe na obszarze Cesarstwa Rosyjskiego i pojawiła się bliska korelacja między narodowością a religią.

W przypadku ziem białoruskich problem świadomości narodowej ich mieszkańców w XIX w. możemy analizować za pomocą wskaźników językowego i religijnego. Żaden z nich nie daje jednak pełnej podstawy do określenia dokładnej struktury narodowościowej ludności Białorusi. Przy uwzględnieniu niskiej świadomości narodowej ludności chłopskiej kryterium językowe zastosowano jako wyznacznik ich przynależności narodowej. W świetle spisu z 1897 r. w pięciu guberniach, w skład których wchodziły ziemie białoruskie, ludność białoruskojęzyczna liczyła 73,3\% (4,7 mln) ogólnej liczby mieszkańców. Z wyjątkiem guberni grodzieńskiej, gdzie według wyników spisu około 50\% ludności było białoruskojęzycznej, w pozostałych czterech guberniach zdecydowanie przeważała ludność, dla której język białoruski był językiem ojczystym. W spisie wykazano,

2 Ibidem, s. 117-119.

3 O roli Cerkwi prawosławnej w dziejach państwa rosyjskiego, por.: L. Bazylow, Historia Rosji, t. 2, Warszawa 1983; L. Kucharzewski, Od białego caratu do czerwonego, t. 2, Warszawa 1990; J. Ochmański, Dzieje Rosji do roku 1861, Warszawa 1986; R. Pipes, Rosja carów, Warszawa 1990; J.C. Roberti, N. Struve, D. Popielovski, Histoire de l'Église russe, Paris 1989; W.A. Serczyk, Poczet władców Rosji, Londyn 1992; Z. Wójcik, Dzieje Rosji 1533-1801, Warszawa 1981; A. Mironowicz, Cerkiew prawosławna w dawnej i we współczesnej Rosji, [w:] Bizancjum - Prawosławie - Romantyzm. Tradycja wschodnia w kulturze XIX wieku, red. K. Korotkich, J. Ławski, Białystok 2004; idem, Prawosławie i unia w dziejach narodu białoruskiego, „Przegląd Wschodni” 2012, t. 12, z. 2 (46), s. 275-309. 
że zaledwie 155 tys. mieszkańców było polskojęzycznych4. Kryterium językowe nie może być jedynym przy określeniu narodowości mieszkańców Białorusi.

O wiele bardziej klarowne przy ustaleniu składu narodowościowego mieszkańców Białorusi w końcu XIX w. było kryterium wyznaniowe. W świetle wyników spisu z 1897 r. prawosławie wyznawało 4,6 mln mieszkańców. Wyznanie to utożsamiano z Białorusinami i z napływową ludnością rosyjską. W spisie wykazano, że było 880 tys. wyznawców Kościoła rzymskokatolickiego, z czego 725 tys. osób używało na co dzień języka białoruskiego ${ }^{5}$. Mimo to na obszarze etnicznie białoruskim Kościół rzymskokatolicki był określany jako Kościół polski. Osoby wyznania rzymskokatolickiego, które posługiwały się językiem białoruskim, nie czuły się Białorusinami. Według ustaleń Włodzimierza Wakara jedynie 40,8 tys. katolików nie uważało się za Polaków6 ${ }^{6}$ Różnice w liczbie katolików narodowości białoruskiej powstały z faktu, że ludność wiejska tego wyznania automatycznie została zakwalifikowana do grupy białoruskojęzycznej. Przedstawiciele ziemiaństwa i inteligencji wyznania katolickiego posługiwali się językiem polskim. Polaryzacja narodowościowa powstała nie na podstawie zróżnicowania języka i kultury, a wyznania. Wyznawcy prawosławia stawali się Białorusinami, a wierni Kościoła rzymskokatolickiego Litwinami i Polakami. Ludność katolicka, która w spisie z 1897 r. została zakwalifikowana jako białoruskojęzyczna czy białoruskiego pochodzenia, w następnych latach stała się nośnikiem polskich idei narodowych. Dowodem na to było opowiedzenie się w latach 1918-1921 katolickiej ludności chłopskiej na terytorium zachodniej i środkowej Białorusi za państwowością polską7.

W historiografii białoruskiej powszechnie panuje pogląd o wielkim wpływie Cerkwi unickiej na rozwój świadomości narodowej jej wyznawców. Pogląd ten trudno zaakceptować, zważywszy na silną latynizację i polonizację tego obrządku na Białorusi po 1720 r., pomimo których w XIX w. obrządek unicki

${ }^{4}$ P. Eberhardt, Problematyka narodowościowa Białorusi w XX wieku, [w:] Białoruś, Czechosłowacja, Litwa, Polska, Ukraina. Mniejszości w świetle spisów statystycznych $X I X-X X$ w., „Materiały Instytutu Europy Środkowo-Wschodniej”, t. 8, red. J. Kłoczowski, Lublin 1996, s. 11.

5 Ibidem, s. 12.

${ }^{6}$ W. Wakar, Rozwój terytorialny narodowości polskiej. Statystyka narodowościowa kresów wschodnich, cz. 3, Kielce 1918, tabela 2.

7 P. Eberhardt, Problematyka narodowościowa Białorusi w XX wieku, s. 14. 
nie był traktowany równoprawnie z obrządkiem rzymskokatolickim przez przedstawicieli tego ostatniego. Nie można tego zjawiska wytłumaczyć tylko walką o rząd dusz między obydwoma odłamami Kościoła katolickiego. Konwersję unitów na obrządek łaciński (dobrowolną lub przymusową) komplikowały relacje, nie tylko kwestie wyznania. Różnice językowe, etniczne i kulturowe pozostawały nadal przeszkodą dla uznania równoprawności katolików obrządku wschodniego przez Kościół rzymskokatolicki. Obejmowało to sprawy prawne, uposażenia materialnego i życia codziennego. Zjawisko takie pojawiło się, kiedy wśród duchowieństwa unickiego ukształtowała się świadomość, że są częścią duchowieństwa katolickiego. Niestety, takiego rozumienia jedności stanu duchownego nie było wśród kleru łacińskiego. Reformy synodu zamojskiego z 1720 r. nie połączyły wschodniej i zachodniej tradycji chrześcijańskiej, a doprowadziły do marginalizacji wschodniej obrzędowości i kultury. Reformy te wprowadziły do życia liturgicznego unitów elementy obrzędowości łacińskiej: msze czytane, odmawianie różańca, modlitwę Anioł Pański, święta charakterystyczne dla wyznawców Kościoła rzymskokatolickiego (np. Niepokalanego Poczęcia NMP), łacińskie: ikonografię i wystrój wnętrza świątyni. Procesy te nie doprowadziły do traktowania unitów przez katolików obrządku zachodniego jako równych sobie, ani też nie wpłynęły na umocnienie się własnej tożsamości narodowej unitów na Białorusi.

Za panowania Pawła I i Aleksandra I unici znaleźli się w pełnej zależności od Kościoła łacińskiego. Problem ten zrozumiała hierarchia unicka, która odzyskawszy wpływ na politykę personalną i obsadę beneficjów, zaczęła na początku XIX w. wracać do wschodniej tradycji cerkiewnej. Arcybiskup Herakliusz Lisowski wyprosił u cara rozdział Kolegium Rzymskokatolickiego na dwa departamenty: rzymskokatolicki i unicki. Władyka Lisowski po otrzymaniu godności metropolity sam zaczął wyznaczać kandydatów na biskupów. Metropolita dążył do ograniczenia wpływów tych bazylianów, którzy opowiadali się za latynizacją liturgii unickiej. Politykę jego kontynuował metropolita Józef Bułhak, dążąc do zachowania odrębności obrządku unickiego. Zadanie to było szczególnie trudne, albowiem wykształceni w polskiej kulturze bazylianie opowiadali się za wejściem unitów do Kościoła łacińskiego i deklarowali swoją przynależność do narodowości polskiej. Unickie duchowieństwo świeckie, niechętne ekspansji rzymskokatolickiej i wsparte lokalnym patriotyzmem, coraz częściej wyrażało chęć połączenia się z prawosławiem. Samodzielności obrządku unickiego broniła jedynie część hierarchii i absolwenci seminarium w Połocku.

Powstaje pytanie o przyczyny takiego zwrotu w postawie elit społeczeństwa unickiego na Białorusi. W latach dwudziestych XIX w. pojawili się pierwsi propagatorzy białoruskiej idei narodowej. Wśród studentów pochodzenia 
białoruskiego w Wilnie i Petersburgu kształtowało się poczucie odmienności od Polaków i Rosjan. Opisywano odrębność języka, kultury i etnografii białoruskiej, wskazywano na Wielkie Księstwo Litewskie jako własną ojczyznę. W tej części Europy był to okres przejścia od narodów politycznych do kulturowych, gdzie religia miała odgrywać istotna rolę. Upadek Rzeczypospolitej spowodował, że zabrakło instytucji państwowych, które mogłyby integrować zróżnicowane wewnętrznie społeczeństwo. W państwie carów słabe ruchy narodowe nie mogły objąć wszystkich mieszkańców ziem białoruskich. Masy chłopskie własną tożsamość kulturową budowały na wspólnocie lokalnej. Ich ojczyzna była regionalna, a nie ideologiczna. Problem idei narodowej ograniczał się do elit społeczeństwa. Jej głosicielami byli początkowo przedstawiciele szlachty i ziemiaństwa. Dopiero w ciągu XIX w., wraz z rozwojem idei narodowych, ich nosicielem stała się inteligencja. Szlachta i ziemiaństwo w hasłach narodowych zaczęły upatrywać czynnika destabilizacji społecznej, powodującego groźbę utraty ich dominującej pozycji w społeczności lokalnej. Pojawienie się tendencji rusyfikacyjnych wymusiło zmianę postawy świadomych elit polskich na Białorusi oraz zaangażowanie się duchowieństwa łacińskiego i części unickiego w polski ruch narodowy. Działacze ci uważali, że tendencjom rusyfikacyjnym może przeciwstawić się jedynie nowoczesna idea narodowa. Kształtował się wówczas typ Polaka katolika, który był trudnym do zaakceptowania dla wszystkich unitów.

Rozdarcie wewnętrzne unitów było widoczne zwłaszcza za panowania Mikołaja I, kiedy Cerkiew unicka stała się terenem rywalizacji polskich i rosyjskich ruchów narodowych, Kościołów łacińskiego i prawosławnego. Podstawową masę wiernych obrządku unickiego stanowili chłopi narodowości białoruskiej. Dla tej grupy społeczeństwa, pozostającej we wspólnocie regionalnej, obca była nowoczesna idea narodowa. Problem haseł narodowych dotyczył wykształconych w polskich i rosyjskich placówkach oświatowych Białorusinów, głównie wyznania unickiego i rzymskokatolickiego.

W tej sytuacji w środowisku duchownych unickich zrodził się ruch, który opowiadał się za zjednoczeniem z Kościołem prawosławnym. Działacze ci byli przeciwni polskiej dominacji kulturowej i religijnej. W ich świadomości tworzyło się poczucie odrębności wobec polskich interesów narodowych i kościelnych, które coraz częściej były artykułowane wśród duchowieństwa łacińskiego i bazylianów. Za zbliżeniem z prawosławiem opowiadali się m.in. profesor Michał Bobrowski (duchowny unicki), Wasyl Łużyński, Jozafat Żarski, Antoni Zubko. Walka z wpływami polskimi i łacińskimi nieuchronnie prowadziła do zbliżenia z prawosławiem, a w konsekwencji do powrotu unitów do prawosławia. Jednym

8 Z. Szybieka, Historia Białorusi 1795-2000, Lublin 2002, s. 72. 
z działaczy tego ruchu był Józef Siemaszko, syn duchownego unickiego, absolwent Głównego Seminarium w Wilnie i przedstawiciel unickiego departamentu w Kolegium Rzymskokatolickim w Petersburgu9

Podjęcie działalności w kierunku zjednoczenia unitów z Cerkwią prawosławną napotkało szereg trudności. Przeciwne zjednoczeniu było duchowieństwo rzymskokatolickie i znaczna część unickiego. Niekonsekwentną politykę w stosunku do unitów prowadziła hierarchia Rosyjskiego Kościoła Prawosławnego i administracja carska. Jedynie dzięki zdolnościom organizacyjnym Józefa Siemaszki udało się zahamować latynizację obrządku unickiego i zainteresować planem zjednoczenia swych współwyznawców oraz wpływowe osoby w Moskwie i Petersburgu. Działalność tę Siemaszko mógł podjąć po objęciu w Konsystorzu wszystkich spraw związanych z funkcjonowaniem Kościoła greckokatolickiego w Rosji. W Petersburgu Siemaszko doprowadził w latach dwudziestych XIX w. do odejścia od obrządku łacińskiego 20 tys. unitów oraz do wydania w 1826 r. przez cara Mikołaja I edyktu zakazującego budowy kościołów łacińskich wśród ludności unickiej i w 1827 r. zakazu wstępowania nieunitów do klasztorów bazyliańskich ${ }^{10}$.

W 1828 r. nastąpiły pierwsze istotne posunięcia oddzielające unitów od katolików - powołanie Greckokatolickiego Kolegium Duchownego, niezależnego od Kolegium Rzymskokatolickiego, i reorganizacja struktur diecezjalnych. Mikołaj I w tym samym roku wydał ukaz poddający Greckounickie Kolegium Duchowne pod zwierzchnictwo biskupa wileńskiego Jozafata Bułhaka ${ }^{11}$. Z czterech diecezji unickich utworzono dwa biskupstwa: białoruskie z siedzibą w Połocku i litewskie z rezydencją w monasterze w Żyrowicach. W przeciwieństwie do hierarchii Rosyjskiej Cerkwi Prawosławnej Józef Siemaszko stopniowo wprowadzał zmiany w systemie zarządzania instytucjami cerkiewnymi, w obrzędach, tradycji i liturgii, np. poprzez zakaz wysyłania unitów do seminarium katolickiego w Wilnie, utworzenie seminarium unickiego w Żyrowicach, oparcie szkolnictwa

9 Dane o życiu Józefa Siemaszki zostały zaczerpnięte z opracowanych przez niego zapisów, por.: И. Семашко, Записки митрополита литовского, т. 1, Санкт-Петербург 1893; Г.М. Киприянович, Высокопреосвященный Иосиф Семашко, митрополит литовский и виленский, Вильно 1894; В. Петручук, Жыцьцё і gзейнасьць Язэпа Сямашкі мітрапаліта літоўскага і віленскага (1798-1868), Беласток 1988, s. 14-36. Biografia Józefa Siemaszki znajduje się w Podręcznej Encyklopedii Katolickiej, t. 35-36, Warszawa 1912.

10 В.Ф. Ботяновский, Иосиф Семашко и воссоеgинение униатов, „Исторический вестник" 1893, t. 14, s. 866.

${ }^{11}$ E. Likowski, Dzieje Kościoła Unickiego na Litwie i Rusi w XVIII i XIX stuleciu, cz. 2, Warszawa 1906, s. 59-60. 
unickiego na systemie szkolnictwa prawosławnego, zrównanie prawne unitów z prawosławnymi w szkołach. Wprowadzone w latach 1828-1829 zmiany doprowadziły do odseparowania się hierarchii unickiej od katolickiej, zorganizowania własnego szkolnictwa i wzmocnienia się nastrojów proprawosławnych wśród duchowieństwa i wiernych Cerkwi greckokatolickiej ${ }^{12}$. W ten sposób Mikołaj I wykorzystał dążenie unitów do samodzielności i odizolował ich od wpływów Kościoła rzymskokatolickiego.

Przeprowadzenie takich zmian wymagało przynajmniej neutralnej postawy biskupów unickich: wileńskiego Jozafata Bułhaka (1817-1839), połockiego Jakuba Martuszewicza (1823-1833), łuckiego Cyryla Sierocińskiego (1827-1833) oraz dwóch sufraganów: Adriana Hołowni, biskupa orszańskiego (1827-1831) i Leona Jaworowskiego, biskupa brzeskiego (1811-1833). Biskupi ci nie cieszyli się zaufaniem władz rosyjskich. Hołownia i Sierociński zmarli w 1831 r., a Jaworowski i Martuszewicz w 1833 r. Jozafat Bułhak, który po Martuszewiczu objął arcybiskupstwo połockie (1833-1838), pozostał wierny unii. Pomimo to arcybiskup połocki podpisał wszystkie rozporządzenia, które miały na celu likwidację obrządku greckokatolickiego. W 1829 r. Józef Siemaszko został sufraganem diecezji białoruskiej.

Józef Siemaszko, znając dzieje wprowadzenia unii, pragnął za wszelką cenę nie dopuścić do przemocy przy jej likwidacji. Zdawał sobie doskonale sprawę, że o postawie wiernych zadecydują ich duchowni. Biskup Siemaszko uważał, że prosty lud stanie się prawosławnym tak szybko, jak szybko jego duchowieństwo stanie się prawosławnym ${ }^{13}$. Ocena jego zyskała potwierdzenie w historii. Parafie unickie szybko stały się prawosławnymi, po tym gdy ich proboszczowie przeszli na „wiarę grecką". Tam, gdzie księża opierali się przyjęciu prawosławia, dochodziło do wystąpień i protestów. Ażeby proces likwidacji unii przybrał charakter łagodny, szczególną rolę w nim przypisano szkołom unickim, a zwłaszcza seminariom w Połocku i Żyrowicach. Wychowywano tam duchownych w duchu teologicznej i kulturowej jedności z Cerkwią prawosławną.

W 1833 r. dokonano wyboru Siemaszki na ordynariusza diecezji litewskiej. Objęcie jej przez Siemaszkę praktycznie oznaczało rozpoczęcie aktu zjednoczenia unitów z Cerkwią prawosławną. Istotną przeszkodę na tym polu stanowiła polityka ordynariusza nowo utworzonego biskupstwa prawosławnego w Połocku. Biskup Smaragd - narodowości rosyjskiej - nie znał specyfiki prawosławia na Białorusi, a tym bardziej unii. Jego administracyjne metody likwidacji unii wywołały liczne protesty ze strony miejscowej ludności. Wprowadzenie

12 H. Dylągowa, Dzieje unii brzeskiej, Warszawa 1996, s. 83-84.

13 и. Семашко, Записки митрополита литовского, т. 1, s. 30. 
wielkoruskiego prawosławia, niszczącego lokalną tradycję, nie zostało chętnie przyjęte w diecezji połockiej przez wiernych Kościoła prawosławnego i greckokatolickiego. Ponownie odradzały się prokatolickie sympatie wśród duchowieństwa unickiego. W tej sytuacji Siemaszko złożył wniosek o podporządkowanie Greckokatolickiego Kolegium Duchownego Świętemu Synodowi, a po jego odrzuceniu, 12 maja 1833 r. złożył prośbę o przyjęcie unitów do Cerkwi prawosławnej. Jednocześnie biskup litewski przeprowadził istotne reformy w Kościele greckokatolickim. Władyka litewski zlikwidował prawo patronatu i ktitorstwa oraz wprowadził do Kościoła unickiego prawosławne księgi liturgiczne. W cerkwiach przywrócono ikonostasy, prawosławne utensylia i szaty liturgiczne ${ }^{14}$.

W celu wprowadzenia wymienionych zmian w Kościele unickim Józef Siemaszko konsekrował w styczniu 1834 r. trzech biskupów pomocniczych: Wasylego Łużyńskiego, Jozafata Żarskiego i Antoniego Zubka. Sam biskup litewski przeprowadzał wizytacje cerkwi unickich, badając stosunek duchowieństwa i wiernych do jego reform. Podczas wizytacji zbierał również podpisy duchownych pod aktem deklaracji przyłączenia do Cerkwi prawosławnej. Przeciwników zjednoczenia spotykały represje ze strony biskupa Siemaszki - usunięcie z parafii 130 dziekanów niechętnych reformom władyki litewskiego i zamknięcie ich w klasztorach ${ }^{15}$. Reakcją na działalność Siemaszki były protesty wiernych części parafii unickich, zwłaszcza na Białostocczyźnie, np. w 1838 r. w Kleszczelach.

Lata 1835-1839 były, podobnie jak w Kościele prawosławnym, okresem dynamicznych zmian w Kościele unickim. Przebudowano strukturę organizacyjną, wprowadzono prawosławne księgi liturgiczne, upodobniono wystrój wewnętrzny cerkwi unickich do prawosławnych. Mimo antyunickiej działalności biskupa połockiego Smaragda i wzmożonej agitacji kleru katolickiego, następował wzrost świadomości podjęcia aktu zjednoczeniowego wśród duchowieństwa greckokatolickiego. Fakt ten pozwolił Józefowi Siemaszce na ponowne zwrócenie się do Świątobliwego Synodu Rosyjskiego Kościoła Prawosławnego

14 A. Mironowicz, Kościół prawosławny na ziemiach dawnej Rzeczypospolitej (15961918), [w:] Prawosławie. Światło wiary i zdrój doświadczenia, red. K. Leśniewski, J. Leśniewska, Lublin 1999, s. 540-541.

15 T. Śliwa, Kościół greckokatolicki na „ziemiach zabranych” (1815-1839) i Kościół greckokatolicki w Królestwie Polskim (1815-1875), [w:] Historia Kościoła w Polsce, t. 2, cz. 1, red. B. Kumor, Z. Obertyński, Poznań 1979, s. 499; A. Mironowicz, W związku z 150 rocznica synodu połockiego (1839-1989), [w:] Chrześcijaństwo w Zwiq̨zku Radzieckim w dobie pierestrojki i głasnosti, red. W. Grzeszczak, E. Śliwka, Pieniężno 1992, s. 142; B. Kumor, Historia Kościoła, t. 7, Lublin 2001, s. 114; M. Radwan, Carat wobec Kościoła greckokatolickiego w zaborze rosyjskim 1796-1839, Roma-Lublin 2001, s. 52-54. 
pismem z 24 września 1836 r. o pozwolenie na przejście na prawosławie. Władze carskie na prośbę biskupa litewskiego zareagowały szybko, tym bardziej że nowym oberprokuratorem Świątobliwego Synodu został zwolennik likwidacji unii na Białorusi metodami administracyjnymi Nikołaj Aleksandrowicz Protazow (1836-1855). Z jego inicjatywy w styczniu 1837 r. został wydany ukaz carski o przekazaniu wszystkich spraw Cerkwi greckokatolickiej oberprokuratorowi Synodu. W tym samym czasie biskup litewski Józef Siemaszko dokonał ponownej wizytacji parafii unickich diecezji litewskiej i białoruskiej, przygotowując duchowieństwo do przejścia na prawosławie. Odmiennie wyglądała sytuacja w diecezji białoruskiej, zarządzanej przez nieprzychylnie nastawionego do zjednoczenia metropolitę Jozafata Bułhaka. Dopiero jego śmierć w 1838 r. i zastąpienie go Wasylem Łużyńskim, zwolennikiem zjednoczenia, przygotowało władyctwo białoruskie do przyjęcia prawosławia ${ }^{16}$.

3 marca 1838 r. Józef Siemaszko został przewodniczącym Kolegium Greckokatolickiego. Istnieją szczegółowe dane z tego roku dotyczące stosunku duchowieństwa unickiego do idei zjednoczenia: W diecezji litewskiej z 1857 duchownych za zjednoczeniem opowiedziało się 760, a w białoruskiej z 680 podpisy złożyło jedynie $186^{17}$. Antyprawosławne nastawienie duchowieństwa w diecezji białoruskiej było wynikiem działalności biskupa Smaragda. Ażeby zmienić tę sytuację, Siemaszko na początku 1839 r. udał się z biskupem brzeskim Antonim Zubko do Połocka, gdzie przeprowadził szeroką agitację za zjednoczeniem. 12 lutego 1839 r. zebrał się sobór, w którym wzięli udział: biskup litewski - Józef Siemaszko, połocki - Bazyli Łużyński i brzeski - Antoni Zubko, 24 wyższych duchownych oraz przedstawiciele społeczności świeckiej. Na soborze proklamowany został akt zjednoczenia, który został podpisany przez jego uczestników. Jednocześnie skierowano pismo do Synodu i cara Mikołaja I z prośbą o przyjęcie unitów do Cerkwi prawosławnej. Do pisma dołączono wykaz 1305 osób duchownych, opowiadających się za tą ideą. Zjednoczenia z prawosławiem nie poparło 593 duchownych unickich ${ }^{18}$.

25 marca 1839 r. Synod Rosyjskiego Kościoła Prawosławnego wydał oświadczenie o następującej treści: biskupów, duchowieństwo i wiernych do dziś greckounickiej Cerkwi zgodnie z prawami i przykładami ojców Cerkwi przyjmujemy do naszej wspólnoty prawosławno-katolickiej, wschodniej, wszechrosyjskiej

16 Ibidem, s. 58.

17 T. Śliwa, Kościół greckokatolicki, s. 502; A. Mironowicz, W związku z 150 rocznica synodu połockiego (1839-1989), s. 143; B. Kumor, Historia Kościoła, t. 7, s. 114.

${ }^{18}$ E. Likowski, Dzieje Kościoła unickiego na Litwie i Rusi w XVIII i XIX wieku, t. 2, Warszawa 1906, s. 107-108; H. Dylągowa, Dzieje unii brzeskiej, s. 89-90. 
Cerkwi. Greckokatolickie Kolegium Duchowne nazwano litewsko-białoruskim i podporządkowano Synodowi. Jego zwierzchnikiem został, podniesiony do godności arcybiskupa, Józef Siemaszko ${ }^{19}$. W ten sposób oficjalnie nastąpiło zjednoczenie Kościoła greckokatolickiego z Cerkwią prawosławną na Białorusi i Litwie.

Przy analizie ostatniego okresu dziejów unii na Białorusi nasuwa się pytanie, dlaczego wyznanie greckokatolickie nie wpłynęło na rozwój świadomości narodowej Białorusinów. Unia mogła funkcjonować jedynie w Rzeczypospolitej, gdzie zachowywała swoją wyraźną odrębność kulturowo-obrzędową. W absolutystycznym państwie carów zachowanie niezależności nie było możliwe. Osłabienie pozycji Kościoła katolickiego i unickiego po jego zaangażowaniu się w polskie sprawy narodowe przyspieszyło opowiedzenie się części unitów za jednością z Rosyjską Cerkwią Prawosławną. Unia został zlikwidowana na Białorusi, zanim białoruscy unici uwolnili się spod kurateli Kościoła rzymskokatolickiego i powołane zostały pełne niezależne struktury organizacyjne.

Mieszkańcy Białorusi, którzy nigdy nie uważali się za Polaków lub Rosjan, znaleźli się w nowej rzeczywistości religijnej. Zamiast polonizacji i latynizacji ich życia religijnego, nastąpił okres jego stopniowego rusyfikowania. W konsekwencji o wyborze wyznania decydował ich stan świadomości religijnej i dystansu do kultury łacińskiej. Część unitów zasiliła Kościół rzymskokatolicki i w następnych pokoleniach poddana była oddziaływaniu polskiego ruchu narodowego. Uniccy Białorusini, którzy powrócili do prawosławia, jedynie w nieznacznym stopniu opowiedzieli się za rosyjską ideą narodową. Dystans językowy i kulturowy, pomimo jedności wyznania okazał się zbyt duży, aby nastąpiła natychmiastowa likwidacja odrębności narodowej.

Rosyjska Cerkiew Prawosławna również nie stała się źródłem odrodzenia narodowego Białorusinów. Początkowo miejscowa Cerkiew prawosławna zachowywała dawne tradycje i obrzędowość. Prawosławie na Białorusi było spadkobiercą dawnej tradycji chrześcijańskiej z silnymi wpływami kultury bizantyjskiej. Chrześcijaństwo wschodnie było stałym elementem życia religijnego w ponadtysiącletniej historii ziem białoruskich. Wschodnia tradycja chrześcijańska w społeczeństwie białoruskim zakorzeniła się we wszystkich formach życia ludności. Szczególne oddziaływanie było widoczne w religijności miejscowej

19 A. Mironowicz, Kościół prawosławny na ziemiach dawnej Rzeczypospolitej (15961918), s. 542. 
ludności i kulturze materialnej. Wśród Białorusinów była przyjmowana w starobiałoruskiej i cerkiewnosłowiańskiej wersji językowej rozległa sfera bizantyjskiej kultury umysłowej. Władze carskie do czasu powstania listopadowego nie wykorzystywały Cerkwi do polityki państwowej, a wpływy Rosyjskiej Cerkwi Prawosławnej nie były na Białorusi tak silne. Prawosławie stało się wyznaniem panującym na Białorusi dopiero po likwidacji unii - wówczas jego rola w społeczeństwa znacznie wzrosła.

Władze rosyjskie narzuciły ośrodkom prawosławnym na Białorusi ustrój synodalno-konsystorski, likwidując ich odrębność prawną i organizacyjną. Od współzarządzania Cerkwią został odsunięty element świecki, w tym bractwa cerkiewne. Kościół prawosławny na ziemiach białoruskich zatracił swoją kulturową specyfikę i organizacyjną niezależność, stając się częścią Rosyjskiej Cerkwi Prawosławnej. Od godności cerkiewnych odsunięto miejscowych duchownych, a na ich miejsce sprowadzono duchowieństwo rosyjskie, które ujednolicało życie parafialne i klasztorne według praw kanonicznych i zwyczajów obowiązujących w Cerkwi rosyjskiej. Polityka unifikacyjna doprowadziła do zlikwidowania miejscowej tradycji, lokalnej kultury cerkiewnej i charakterystycznej dla ziem białoruskich obrzędowości20.

Po likwidacji unii nie zmieniła się sytuacja materialna Cerkwi prawosławnej. Władze narzuciły ziemiaństwu obowiązek budowania świątyń, utrzymania duchownych i szkół cerkiewnych. Ziemiaństwo wyznania katolickiego nie było zainteresowane rozwojem prawosławia. W tej sytuacji w 1842 r. rząd carski odebrał majątki duchowieństwu i przejął obowiązek utrzymania kleru Kościoła prawosławnego i rzymskokatolickiego. Decyzja ta nie zrównała duchownych prawosławnych z katolickimi. Wśród wyznawców prawosławia większość stanowiła ludność wiejska, a wśród wyznawców katolicyzmu przeważali przedstawiciele ziemiaństwa i szlachty. Ci ostatni szczodrze wspierali materialnie i politycznie duchowieństwo łacińskie. W świadomości społecznej prawosławie pozostało wyznaniem ludu, a katolicyzm wyznaniem szlachty.

Rząd carski, wbrew panującej w polskiej historiografii opinii, nie troszczył się o status materialny Cerkwi prawosławnej. W polityce władz carskich ważniejsze

20 O dziejach Kościoła prawosławnego do 1918 r. por.: L. Bieńkowski, Organizacja Kościoła wschodniego w Polsce, [w:] Kościół w Polsce. Studia nad historia Kościoła katolickiego w Polsce, red. J. Kłoczowski, t. 2, cz. 2, Kraków 1969, s. 781-1049; A. Mironowicz,Kościół prawosławny na ziemiach dawnej Rzeczypospolitej (1596-1918), s. 473-548; idem, Kościół prawosławny w dawnej Rzeczypospolitej, Białystok 2001; idem, Kościół prawosławny w państwie Piastów i Jagiellonów, Białystok 2003; idem, Bractwa cerkiewne w Rzeczypospolitej, Białystok 2003. 
było oczyszczenie białoruskiego prawosławia z miejscowych tradycji i narzucenie mu wielkoruskiej tradycji religijnej. Politykę tę realizowano poprzez zrusyfikowane duchowieństwo i nakazy administracyjne. Odrodzenie białoruskiej prawosławnej tradycji religijnej sprzed 1795 r. nie było możliwe. W 1840 r. duchowni prawosławni stracili prawo wygłaszania kazań po białorusku. Duchowni pochodzący z rodzin unickich zostali zastąpieni na Białorusi klerem o mentalności wielkoruskiej. Kler rosyjski i zrusyfikowane duchowieństwo miejscowego pochodzenia nie reprezentowali białoruskich interesów narodowych. Lud białoruski wyznania prawosławnego był traktowany przez duchowieństwo i administrację carską za społeczność rosyjską ${ }^{21}$. Cerkiew prawosławna na Białorusi stała się realizatorem polityki imperialnej państwa. Elementami rusyfikującymi były: wprowadzenie wielkoruskiej obrzędowości, negacja lokalnych tradycji religijnych, charakter szkolnictwa cerkiewnego czy współorganizowanie z instytucjami państwowymi obchodów rocznic związanych z historią Rosji, np.: 300-lecia panowania dynastii Romanowych w 1913 r., 100-lecia urodzin Aleksandra Puszkina, 50-lecia zwolnienia chłopów z pańszczyzny, 10-lecia powołania eparchii grodzieńskiej.

Pomimo tych negatywnych dla białoruskiego odrodzenia narodowego zjawisk w Cerkwi prawosławnej nie można zgodzić się z tezą Ryszarda Radzika, że unia i katolicyzm dawały Białorusinom więcej szans na zbudowanie narodowej tożsamości, aniżeli zależne od państwa prawosławie ${ }^{22}$. Teza ta nie znajduje potwierdzenia w rozwoju białoruskiego ruchu narodowego. Elity katolickie czuły się przedstawicielami narodu polskiego lub litewskiego. Roli Cerkwi unickiej na Białorusi nie można porównywać z wkładem duchownych unickich w rozwój ukraińskiej świadomości narodowej w Galicji. W okresie, kiedy kształtowały się nowożytne ruchy narodowe w tej części Europy, unitów na terytorium ziem białoruskich już nie było. Większość Białorusinów w XIX w. znajdowała się w strukturach Cerkwi prawosławnej. Procesy rusyfikacyjne, wpierane przez państwo, nie zniszczyły świadomości narodowej wiernych. Fakt ten znajduje potwierdzenie w aktywnym udziale Białorusinów wyznania prawosławnego w ruchu narodowym w czasie I wojny światowej i w okresie międzywojennym. Trzeba pamiętać, że świadomość narodowa prawosławnych Białorusinów kształtowała się w trudniejszych warunkach, albowiem ich wyznanie było utożsamiane z panującą religią zaborcy

${ }^{21}$ R. Radzik, Rozwój narodowy społeczności polskiej i białoruskiej w okresie zaborów, [w:] Historycy wobec problemów tożsamości narodowej i europejskiej - między nacjonalizmem a uniwersalizmem, XVIII-XX wiek, „Materiały Instytutu Europy Środkowo-Wschodniej”, t. 1, red. J. Kłoczowski, Lublin 1992, s. 42-43.

22 Ibidem, s. 40. 
Na ziemiach białoruskich, w społeczeństwie przedindustrialnym, trudno było rozwijać jakiekolwiek idee narodowe, a białoruską w szczególności. Osoby, które wyszły z tego środowiska, znalazły się w sferze oddziaływania polskich i rosyjskich haseł narodowych. Tylko nieliczni z wychodźców stali się nośnikami białoruskiego ruchu narodowego. Prawosławni Białorusini z rezerwą odnosili się do wielkoruskiego imperializmu. Ludność wiejska wyznania prawosławnego, pozbawiona swych elit, nie była przygotowana do przyjęcia haseł narodowych, zwłaszcza, że pierwsi twórcy dziewiętnastowiecznej literatury białoruskiej byli wyznania katolickiego. Ich twórczość nie przeciwstawiała się kulturze polskiej, była z nią nierozerwalnie związana. Z tego powodu białoruskojęzyczna literatura, przepełniona polskością, nie była zrozumiała dla mas białoruskich, pozbawionych własnej inteligencji i silnego mieszczaństwa.

Większość Białorusinów, zawieszonych między polskością a rosyjskością, nie była zainteresowana jakimikolwiek ideami narodowymi. Lokalna społeczność prawosławna broniła swego etnicznego pochodzenia, trwając w poczuciu obcości wobec Polaków i Rosjan. Cerkiew prawosławna, choć miała w drugiej połowie XIX w. narodowy rosyjski charakter, nie zmieniła mentalności Białorusinów. Ich siłą okazała się odporność etnicznego, chłopskiego społeczeństwa na nowożytne hasła narodowe. Polonizowały lub rusyfikowały się jedynie osoby, które opuściły swoje etniczne terytoria. Nieliczni przedstawiciele inteligencji i szlachty z ukształtowaną białoruską świadomością narodową nie mogli zmienić tej sytuacji. Zmieniła się ona dopiero, kiedy po upadku Imperium Rosyjskiego pojawiły się próby budowy własnej białoruskiej państwowości. Wstrząs wywołany I wojną światową w istotny sposób wpłynął na świadomość mas białoruskich. Białorusini wyznania prawosławnego znaleźli się wówczas wśród budowniczych swej państwowości i coraz częściej opowiadali się za nadaniem życiu religijnemu charakteru narodowego. W społeczności białoruskiej kształtowało się pojęcie jedności Białorusina i prawosławnego. Wraz z upadkiem państwa rosyjskiego czynnik wyznaniowy stał się elementem odróżniającym Białorusinów od ludności polskiej.

\section{Bibliografia}

Babuzan V.M., Narody Rossii w pervoj polovine XIX v. Čisliennost' i ètničeskij sostav, Moskva 1992 [Бабузан В.M., Нароgы России в первой половине XIX в. Численность и этнический состав, Москва 1992].

Botânovskij V.F., Iosif Semaško i vossoedinenie uniatov, „Istoričeskij Vestnik” [Ботяновский

В.Ф., Иоси Ф Семашко и воссоеgинение униатов, „Исторический вестник”] 1893, t. 14, s. 857-875.

Bazylow L., Historia Rosji, t. 2, Warszawa 1983. 
Wpływ wyznań religijnych na kształtowanie się białoruskiej świadomości...

Bieńkowski L., Organizacja Kościoła wschodniego w Polsce, [w:] Kościół w Polsce. Studia nad historiq Kościoła katolickiego w Polsce, red. J. Kłoczowski, t. 2, cz. 2, Kraków 1969, s. 781-1049.

Dylągowa H., Dzieje unii brzeskiej, Warszawa 1996.

Eberhardt P., Geografia ludności Rosji, Warszawa 2002.

Eberhardt P., Problematyka narodowościowa Białorusi w XX wieku, [w:] Białoruś, Czechosłowacja, Litwa, Polska, Ukraina. Mniejszości w świetle spisów statystycznych XIX$X X$ w., „Materiały Instytutu Europy Środkowo-Wschodniej”, t. 8, red. J. Kłoczowski, Lublin 1996, s. 9-35.

Kipriânovič G.M., Vysokopreosvâŝennyj Iosif Semaško, mitropolit litovskij i vilenskij, Vil'na 1894 [Киприянович Г.М., Высокопреосвященный Иосиф Семашко, митрополит литовский и виленский, Вильна 1894].

Kucharzewski L., Od białego caratu do czerwonego, t. 2, Warszawa 1990.

Kumor B., Historia Kościoła, t. 7, Lublin 2001.

Likowski E., Dzieje Kościoła Unickiego na Litwie i Rusi w XVIII i XIX stuleciu, cz. 2, Warszawa 1906.

Mironowicz A., Bractwa cerkiewne w Rzeczypospolitej, Białystok 2003.

Mironowicz A., Cerkiew prawosławna w dawnej i we współczesnej Rosji, [w:] Bizancjum Prawosławie - Romantyzm. Tradycja wschodnia w kulturze XIX wieku, red. K. Korotkich, J. Ławski, Białystok 2004, s. 55-74.

Mironowicz A., Kościół prawosławny na ziemiach dawnej Rzeczypospolitej (1596-1918), [w:] Prawosławie. Światło wiary i zdrój doświadczenia, red. K. Leśniewski, J. Leśniewska, Lublin 1999, s. 473-548.

Mironowicz A., Kościół prawosławny w dawnej Rzeczypospolitej, Białystok 2001.

Mironowicz A., Kościół prawosławny w państwie Piastów i Jagiellonów, Białystok 2003.

Mironowicz A., Prawosławie i unia w dziejach narodu białoruskiego, „Przegląd Wschodni” 2012, t. 12, z. 2 (46), s. 275-309.

Mironowicz A., W związku z 150 rocznica synodu połockiego (1839-1989), [w:] Chrześcijaństwo w Zwiq̨zku Radzieckim w dobie pierestrojki i głasnosti, red. W. Grzeszczak, E. Śliwka, Pieniężno 1992, s. 137-146.

Ochmański J., Dzieje Rosji do roku 1861, Warszawa 1986.

Petručuk V., Žyc'cë ì dzejnas 'c' Âzèpa Sâmaškì - mitrapalita litoǔskaga ì vilenskaga (17981868), Belastok 1988, s. 14-36 [Петручук В., Жыцьцё i gзейнасьць Язэпа Сямашкі мітрапаліта літоўскага і віленскага (1798-1868), Беласток 1988, с. 14-36].

Pipes R., Rosja carów, Warszawa 1990.

Podręczna Encyklopedia Katolicka, t. 35-36, Warszawa 1912.

Radwan M., Carat wobec Kościoła greckokatolickiego w zaborze rosyjskim 1796-1839, Roma-Lublin 2001.

Radzik R., Rozwój narodowy społeczności polskiej i białoruskiej w okresie zaborów, [w:] Historycy wobec problemów tożsamości narodowej i europejskiej - między nacjonalizmem a uniwersalizmem XVIII-XX wiek, „Materiały Instytutu Europy Środkowo-Wschodniej”, t. 1, red. J. Kłoczowski, Lublin 1992, s. 37-44. 
Roberti J.C., Popielovski D., Struve N., Historie de l'Église russe, Paris 1989.

Serczyk W.A., Poczet władców Rosji, Londyn 1992.

Semaško I., Zapiski mitropolita litovskogo, t. 1, Sankt-Peterburg 1893 [Семашко И., Записки митрополита литовского, т. 1, Санкт-Петербург 1893].

Szybieka Z., Historia Białorusi 1795-2000, Lublin 2002.

Śliwa T., Kościół greckokatolicki na „ziemiach zabranych” (1815-1839) i Kościół greckokatolicki w Królestwie Polskim (1815-1875), [w:] Historia Kościoła w Polsce, t. 2, cz. 1, red. B. Kumor, Z. Obertyński, Poznań 1979, s. 497-511.

Wakar W., Rozwój terytorialny narodowości polskiej. Statystyka narodowościowa kresów wschodnich, Cz. 3, Kielce 1918.

Wójcik Z., Dzieje Rosji 1533-1801, Warszawa 1981. 


\section{Францішак Багушэвіч - ідэолаг беларускай нацыянальнай ідэі?}

\section{Franciszek Bohuszewicz - an ideologist of the Belarusian national idea?}

The article is a polemic with Oleg Łatyszonek, a Belarusian historian from Białystok, over whether Franciszek Bohuszewicz can be considered an ideologist and a creator of the Belarusian national idea. Based on Bohuszewicz's poems (published under pen name Maciej Buraczok), statements of the poet's relatives and friends, obituaries, and material of 20th-century researchers, the author claims that, regardless of the persecution by the authorities and the censorship of his works, Bohuszewicz accomplished his mission: he showed the hard life of Belarusians in the times after the enfranchisement of peasants, he named those who were to blame for their situation and outlined ways to overcome it (through legal action, education and even death for freedom, like the Kościuszko Uprising fighters). Bohuszewicz was therefore an ideologist and a creator of the Belarusian national idea in the second half of the 19th century.

Ke y w ord s: Belarusian national idea, Franciszek Bohuszewicz's work, Belarusian language, "sad pipe", censorship

\section{Franciszek Bohuszewicz - ideolog białoruskiej idei narodowej?}

W artykule autor polemizuje z białoruskim historykiem z Białegostoku Olegiem Łatyszonkiem na temat tego, czy Franciszka Bohuszewicza można uznać za ideologa i współtwórcę białoruskiej idei narodowej. Opierając się na analizie wierszy Bohuszewicza (wydawanych pod pseudonimem Maciej Buraczok), wypowiedziach bliskich i znajomych poety, nekrologach oraz materiałach badaczy z XX w., autor stwierdza, że nie bacząc na prześladowania ze strony władzy i na cenzurę jego utworów, Bohuszewicz wypełnił swoją misję: pokazał ciężkie życie Białorusinów w czasach po reformie uwłaszczającej chłopów, wskazał winowajców tej sytuacji i nakreślił drogę wyjścia (poprzez działania prawne, edukację, a nawet śmierć za wolność - tak jak kościuszkowcy). Był więc ideologiem i współtwórcą białoruskiej idei narodowej drugiej połowy XIX w., z którego utworów podejścia do sprawy białoruskiej uczyli się jego młodsi koledzy.

Słowa kluczowe: białoruska idea narodowa, twórczość Franciszka Bohuszewicza, język białoruski, „smutna dudka”, cenzura 
У канцы 2019 года лабараторыя "Новак" правяла сярод насельніцтва сацыялагічнае апытанне пра герояў беларускай гісторыі. Прапаноўваліся 22 асобы, сярод якіх быў і Францішак Багушэвіч. Ён заняў у рэйтынгу пятае месца з вынікам 67,1\%². У 2010 годзе грамадска-культурная кампанія “Будзьма беларусамі!" правяла галасаванне за гістарычных асоб усіх часоў, якія ствараюць пазітыўны вобраз Беларусі ў свеце. Багушэвіч набраў 52 галасы з 609 рэспандэнтаў і апынуўся на 11 месцы ў топ-12². На наш погляд, Багушэвіч заслугоўвае большай увагі і толькі няведанне грамадскасцю яго сапраўднай ролі і месца ў гісторыі Беларусі прывяло да такога выніку ў апытаннях грамадства.

Звернемся да поглядаў даследчыкаў жыцця і творчасці Багушэвіча і высветлім яго сапраўднае значэнне. Аказалася, што па-рознаму глядзяць на яго даследчыкі Беларусі і беларускія вучоныя па-за яе межамі.

Паводле прац прафесара, доктара гістарычных навук Універсітэта ў Беластоку Алега Латышонка, раней надрукаваных у розных публікацыях, а намі ўзятых з яго кнігі Нацыянальнасць - Беларус, складваецца наступны вобраз Багушэвіча.

У 2003 годзе ў артыкуле Нацыянальнасць Мацея Бурачка Латышонак сцвярджаў:

Няма сумневу, што сам Францішак Багушэвіч лічыў сябе палякам і ніколі не акрэсліваў сябе як беларуса. Мацей Бурачок таксама прызнаў сябе палякам, а не беларусам. Застаецца задаць рытарычнае пытанне: Як можна лічыць Багушэвіча беларускім нацыянальным паэтам, калі ён сам, і герой ягоных твораў былі палякамі? ${ }^{3}$.

У 2010 годзе ў інтэрв’ю Віктару Корбуту з Беларускай службы Польскага радыё (Варшава) Латышонак адказвае:

Як Багушэвіч, так і Вінцэнт Дунін-Марцінкевіч былі беларускімі літаратарамі, бо пісалі па-беларуску, але яны не дэкларавалі сябе нідзе і ніколі беларусамі, таму не маглі быць аўтарамі беларускай нацыянальнай ідэі. Наогул, беларуская нацыянальная ідэя развівалася арганічна на працягу некалькіх стагоддзяў і як такая не мае свайго аўтара... Багушэвічаў унёсак важкі ў тым сэнсе, што паэт

1 “Наша Ніва", 15.05.2010.

2 Vide: 3. Шыбека, Героі беларускай гісторыі ў памяці беларусаў. Да праблемы фарміравання грамаgзянскай нацыі, [у:] Новае слова у гісторыя і культуралогіi, рэд. А.А. Суша, Мінск 2012, с. 123.

3 А. Латышонак, Нацыянальнасць - Беларус, Вільня 2012, с. 507. 
вельмі эмацыйна выступіў у абарону беларускай мовы і ўзвышана загаварыў пра Беларусь. Але ў той час ідэя існавання Беларусі ды беларускай нацыі ўжо гучала 4 .

“Адзіным тэкстам Багушэвіча, - піша Латышонак, - у якім ім былі ўжытыя словы «Беларусь», «беларускі», з'яўляецца Праgмова ga «Дуgкі беларускай»". Аб этнічнай самасвядомасці беларусаў (пра тутэйшасць) у разуменні Багушэвіча Латышонак піша ў артыкуле Міт “тутэйшых”:

У той час [тады, калі М. Багдановіч, да тутэйшых адносіў сялян - В. Ш.] - паэт Францішак Багушэвіч да "тутэйшых" залічваў не толькі селяніна (верш Хрэсьбіны Мацюка), але і пана (верш Немец). Што цікава ў ягонай творчасці “тутэйшымі" могуць быць элементы краявіду, як ні дзіўна - нават такія не пастаянныя, як хмаркі. Варта прытым адзначыць, што “тутэйшыя” Багушэвіча - каталікі. Багушэвічава мадэль "тутэйшасці" ўпісваецца ў ідэалогію "краёвасці".

Латышонак прызнае:

Вельмі рана на зусім іншы ўзровень падняў “тутэйшасць” Францішак Багушэвіч, залічваючы да "тутэйшых" усё карэннае насельніцтва зямель былога Вялікага Княства Літоўскага, нягледзячы на яго сацыяльны статус. Такім чынам Багушэвіч з'яўляецца стваральнікам станоўчага міта "тутэйшых", і ў гэтым сэнсе пачынальнікам як дамадэрнавай ідэі “краёвасці", так і мадэрнай беларускай нацыянальнай ідэі ды пастмадэрнай ідэі “тутэйшасці" Цэнтра этнакасмалогіi "Крыўя”.

У іншым артыкуле Нацыянальнасць Мацея Бурачка (2003 год) Латышонак дадае:

I для Бурачка, і для Багушэвіча як “мужык”, так і “пан” - гэта "тутэйшыя", а знікненне "тутэйшага" пана абярнецца толькі ліхам [аўтар прыводзіць урывак з верша Немец - В. Ш.]. Па сутнасці Багушэвіч ідэалагічна няшмат чым адрозніваецца ад Дуніна-Марцінкевіча, якога сам крытыкуе ў Праgмове ga "Смыка беларускага".

Латышонак сцвярджае, што толькі ў ёй “Багушэвіч прапагандуе постлітоўскую беларускую культуру. [...] У сваёй беларускай паэзіі ён прадстаўляе толькі навакольную рэчаіснасць: працэс набыцця польскай нацыянальнай

\footnotetext{
${ }^{4}$ Ibidem, c. 551.

5 Ibidem, c. 504, 494.

6 Ibidem, c. 501.
} 
свядомасці тутэйшымі ў ваколіцах Вільні, у Кіянах і Рыконях"7, 8 . У працы Напачатку было слова (відаць, больш позняга перыяду, 2012 год?), Латышонак зноў сцвярджае пра Багушэвіча:

Паэт гэты не напісаў ніводнага мастацкага твора, у якім выявілася 6 ягонае нацыянальнае пачуццё [...]. У сваёй прадмове да Дуgкі беларускай Багушэвіч праявіў беларускі патрыятызм. Усё ж такі, як і яго папярэднікі, не бачыць ён гістарычнай самабытнасці Беларусі. Гістарычнай памяццю Багушэвіч перавысіў Марцінкевіча толькі на некалькі пакаленняў літоўскіх князёў і ўспомніў Вітэнэса?.

\section{Блізкія людзі, знаёмыя, народ і даследчыкі пачатку XX стагоддзя пра Багушэвіча}

Калі Багушэвіча хавалі вясной 1900 года, дык трэба было даставіць цела нябожчыка з Кушлян у Жупраны і мужыкі неслі яго на сваіх плячах, нягледзячы на страшнае разводдзе - не хацелі везці свайго паэта коньмі ${ }^{10}$. Са слоў прыяцеля Багушэвіча Зыгмунта Нагродскага, пляменніца літаратара Юлія Радзевіч успамінала, што на яго магілу віленская дэлегацыя “з сферы працоўнае” паклалі вялікі вянок з яліны, які замест стужкі быў перавязаны тонкім белым сялянскім ручніком з беларускім надпісам "Змоўклі песні тыя, што іграў на дудцы" (з верша Вецер gзьме і вые) ${ }^{11}$.

Пасля смерці Багушэвіча ў 1900 годзе ў друку з'явіліся некролагі ці артыкулы і ва ўсіх іх гаварылася пра яго як прыхільніка беларускасці. Польскамоўны часопіс "Край”, які выдаваўся ў Пецярбургу і з якім Багушэвіч супрацоўнічаў у 1885-1891 гадах, назваў яго "народным беларускім пісьменнікам". У варшаўскім штотыднёвіку "Biesiada Literacka” Люцыян Узембла напісаў: "Багушэвіч у нашай старонцы славіўся як знаўца і самы палымяны аматар беларушчыны”. У артыкулах Напалеона Роубы 1900-1928

7 Пададзены пералік месцаў, звязаных з жыццём і дзейнасцю Багушэвіча. Кіены або Кены знаходіліся недалёка каля багушэвічаўскіх Свіран (цяпер в. Жамыслаў Гродзенскай вобласці).

8 А. Латышонак, Нацыянальнасць - Беларус, с. 507.

9 Ibidem, c. 456.

10 А.А. Лойка, Гісторыя беларускай літаратуры. Дакастрычніцкі перыяg. У 2 ч., ч. 1: Паgручнік gля філалагічнага факультэта, Мінск 1989.

11 Пачынальнікі. 3 гісторыка-літаратурных матэрыялаў ХІХ ст., уклад. Г.В. Кісялёў, Мінск 2003, с. 440; Ф. Багушэвіч, Творы, Мінск 1967, с. 115. 
гадоў Багушэвіч называецца "паэтам Белай Русі", “беларускім песняром і паэтам"12.

У 1921 годзе першы гісторык беларускай літаратуры Максім Гарэцкі напісаў пра Багушэвіча: "Ён - першы ўсенародны беларускі правадыр і першы беларускі пясняр-рэвалюцыянер. Ён першы нацыянальны беларускі паэт, дагэтуль адзін з самых вялікіх у гэтым значэнні [...]"13.

Ксёндз Адам Станкевіч піша, што ў 1930 годзе беларусы-католікі з ваколіц Кушлян і Жупран яшчэ памяталі Багушэвіча і гаварылі, што "надта ён мужыкоў любіў, з імі ахвотна прабываў, гаварыў і насіў сярмягу"14.

Казімір Сваяк у артыкуле Fr. Bahušewič - piasniar biełaruski напісаў:

Так вось з твораў сваіх Багушэвіч паказваецца нам, як чысты беларус і гэтага нам досыць, каб паставіць яго між сваімі пісьменнікамі, хоць радня яго мо і не прызнаецца да Беларусі [...]. Не дзіва, што народ уважаў яго "за свайго" і смерць яго вызвала шчыры жаль, што адбіўся шырокім спачуццём па цэлай Беларусі, бо з ім сышоў са свету першы пісьменнік-дэмакрат, які меў адвагу заступіцца за беднату і паказаць свету нашу крыўду. Ён пачынае рад пісьменнікаў, што будуць бараніць таксама паднявольнага, мо нават гарачэй, але вось у чым не зраўняюцца з Багушэвічам: не абоймуць цэласці беларускай душы, а ён патрапіў гэта зрабіць $[\ldots]^{15}$.

У 1930 годзе А. Станкевіч, якога цяперашнія гісторыкі Андрэй Вашкевіч і Аляксандр Пашкевіч назвалі Званаром Незалежнасці16, выдаў у Вільні кніжачку па-беларуску лацінкай Franciš Bahušewič. Jaho żyćcio i tworčaść. U tryccatyja uhodki śmierci (1900-1930). На яе старонках ён называе Багушэвіча "Бацькай беларускага сучаснага адраджэння", "Вялікім Беларусам", "Вялікім Адраджэнцам", "Бацькам духовым", "Патрыярхам адраджэння беларускага народу”"17. Каб чытач добра зразумеў Багушэвіча, А. Станкевіч звяртае ўвагу на час, у якім ён жыў - час узмоцненай і уссебаковай русіфікацыі: забароны ўніяцтва і прымусовага пераводу ў праваслауе, спыненне дзейнасці Статута ВКЛ, забароны беларускай мовы і закрыцця Віленскага ўніверсітэта,

12 Пачынальнікі, с. 414, 417, 422, 423, 428.

13 М. Гарэцкі, Гісторыя беларускае літаратуры, Вільня 1921, с. 117.

14 А. Станкевіч, 3 Богам gа Беларусі. Збор твораў, уклад., рэд., каментары А. Пашкевіч, А. Вашкевіч, Вільня 2008, с. 241.

15 K. Swajak, Fr. Bahušewič - piaśniar biełaruski, "Krynica” 1920, № 2, 3, 4, 5; А. Станкевіч, 3 Богам gа Беларусі, с. 241-242.

16 А. Станкевіч, 3 Богам gа Беларусі, с. 17.

17 Ibidem, c. 239, 241, 251, 257, 263. 
перайменавання краіны уу Паўночна-Заходні край. "[...] няма хлеба, няма асветы, няма волі", - як вобразна напісаў К. Сваяк, а адначасова "[...] на Беларусі падрыхтоўвалася і нараджалася ўзвышаная ідэя прыгнечанае мужыцкае беларускае нацыі і адбывалася ўсведамленне самастойнасці беларускай нацыянальнай культуры", - сцвярджаў Аляксандр Цвікевіч18.

\section{Сучасныя даследчыкі пра Францішка Багушэвіча}

У маніфестацыйны перыяд перад Студзеньскім паўстаннем Багушэвіч належаў да нелегальнага таварыства "Пянтковічы", якое існавала на Ашмяншчыне у 1861-1862 гадах. Падчас паўстання 1863 года Багушэвіч быў у партызанскім аддзеле Людвіка Нарбута. У Жупранах хадзілі легенды, што адыходзячы ў паўстанне паэт выступіў перад местачкоўцамі з каменя, які стаяў на рыначнай плошчы ${ }^{19}$. Пасля паражэння паўстання Багушэвіч вымушаны быў пакінуць Бацькаўшчыну, куды змог вярнуцца толькі праз дваццаць гадоў. Генадзь Кісялёў не мае сумнення, што пішучы верш Ахвяра паэт успамінаў сваіх баявых сяброўㄹ․ Працытуем з яго ўрывак:

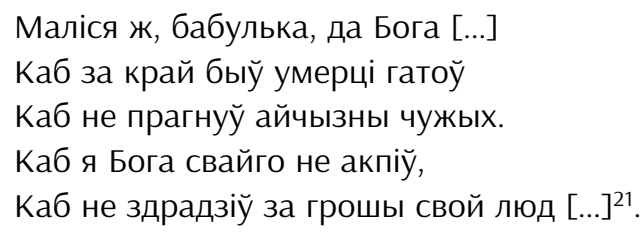

Даследчык Г. Кісялёў знайшоў у блізкім акружэнні Багушэвіча Габрыеля (Гаўрылу) Радзевіча, роднага пляменніка яго жонкі Габрыелі Міхайлаўны Шклёнік. Шукаючы пра яго матэрыялы, Кісялёў даведаўся, што Радзевіч разам з жонкай Юліяй былі ў “Народнай волі", а потым чальцамі адной з першых марксісцкіх арганізацый у Расіі - групы Міхаіла Бруснева (інакш "Рабочы саюз”), якая дзейнічала ў Пецярбургу ў 1889-1892 гадах. 37 лютага 1892 года Радзевіч шэсць месяцаў сядзеў у віленскай турме, а жонка - пад паліцэйскім наглядам. Затым яны жылі ў Вільні, дзе і Багушэвіч. Даследчык адзначае:

18 А. Цьвікевіч, Запаgно-русізм. Нарысы з гісторыі і грамаgскай мысьлі на Беларусі у ХIX і пачатку XX в., Менск 1929, с. 186.

19 А.А. Лойка, Гісторыя беларускай літаратуры, с. 248.

20 Г. Кісялёў, Смак беларушчыны, Мінск 2013, с. 62.

21 Ф. Багушэвіч, Творы, с. 82. 
3 Радзевічамі ў жыццё беларускага пісьменніка ўвайшло нешта вельмі і вельмі важнае, істотнае, хоць, па ўсім, марксісцкіх поглядаў ён не падзяляў, а ў пісьме 1893 года выказаў нават непрыхільнасць да экспрапрыяцый, звязаных, на яго думку, з "камунізмам" і “сацыялізмам". Але за народ, мы ведаем, стаяў гарою і паноў не мілаваў²2.

Юлія Радзевіч-Вайчынская ўспамінаецца ва ўспамінах Нагродскага побач з Цёткай, Зоськай Верас і Уладзіславай Станкевіч сярод працаўнікоў беларускай асветы пачатку XX стагоддзя.

Багушэвіч быў беларускім народнікам 1870-х гадоў, якія ад папярэднікаў сваіх, народнікаў 1860-х гадоў, ведалі, што народ не гатовы да рэвалюцыі і яго трэба рыхтаваць да яе. Яны абуджалі ў народзе яго сацыяльную і нацыянальную свядомасць. Багушэвіч заявіў аб самабытнасці беларускага народу, які мае сваю тэрыторыю (Беларусь і Літва цягнуліся ад Балтыйскага мора да Чорнага), гісторыю (ад панавання літоўскага князя Вітэнэса), мову, культуру. Звернемся да Праgмовы ga “Дуgкі беларускай”: “Можа хто спытае: гдзе ж цяпер Беларусь? Там, братцы, яна, гдзе наша мова жывець: яна ад Вільні да Мазыра, ад Вітэбска за малым не да чарнігава, гдзе Гродна, Мінск, магілёў, Вільня і шмат мястэчак і вёсак [...]”.

А пра мову Багушэвіч / Мацей Бурачок тлумачыў:

Я сам калісць думаў, што мова наша - "мужыцкая" мова і толькі таго! Але, паздароў Божа добрых людцоў, як навучылі мяне чытаць-пісаць, з той пары я шмат гдзе быў, шмат чаго відзеў і чытаў: і пераканаўся, што мова нашая ёсць такая ж людская і панская, як і французская, альбо нямецкая, альбо і іншая якая. Чытаў я ці мала старых папераў, па дзвесце, па трыста гадоў таму пісаных у нашай зямлі і пісаных вялікімі панамі а нашай мовай чысцюсенькай, як бы вось цяпер пісалася. [...] Наша мова для нас святая, бо яна нам ад Бога даная, як і другім добрым людцам, і гаворым жа мы ёю шмат і добрага, але так мы ўжо самі пусцілі яе на здзек, не раўнуючы, як і паны вялікія ахотней гавораць па-французску як па-свойму. Нас жа не жменька, а з шэсць мільёнаў. [...] Шмат было такіх народаў, што страцілі найперш мову сваю, так як той чалавек прад скананнем, катораму мову займе, а потым і зусім замёрлі. Не пакідайце ж мовы нашай беларускай, каб не ўмёрлі! Пазнаюць людзей ці па гаворцы, ці па адзежы, хто якую носе; ото ж гаворка, язык і ёсць адзежа душы"23.

22 Г. Кісялёў, Смак беларушчыны, с. 74, 77, 79, 83.

23 Ф. Багушэвіч, Творы, уклад., прадм. Я. Янушкевіч; камент. У Содаль, Я. Янушкевіч, 2-е выд., Мінск 2001, с. 21-22. 
Багушевічава Дуgка беларуская не была "дудкай весялушкай”, яна стала “жалейкай смутнай”:

Ну, дык грай жа, грай жа

Усё спамінай жа...

Штодзень і штоночы

Плач, як мае вочы,

Над народу доляй,

I плач штораз болей.

Галасі, як матка,

Хаваючы дзеці,

Дзень, другі і трэці

Іграй слёзным тонам

Над народу сконам! [...] ${ }^{24}$

Па сваёй працы адваката Багушэвіч паездзіў па вёсках, дзе жылі сяляне, якіх ён бараніў на судах і добра пабачыў, у якім становішчы знаходзіліся яны ў паслярэформенны час. У вершах, змешчаных у першым зборніку, шмат гаворыцца пра гаротны стан селяніна. Вось словы з верша Дурны мужык як варона:

Ці ж не дурань мужык гэта:

Гарэ, сее усё лета,

А як прыйдуцца дажынкі,

Няма збожжа ні асьмінкі,

А даждаўшы на Каляды,

Мужыкі мякінцы рады...

Глядзі, касцёл аж да неба,

Воласць бляхамі пакрыта!

Срэбрам скрые, калі трэба,

Бо за гэта яго біта,

А сам жывець у мокрай яме,

Дзверы заткнуў анучамі!

Дык крычыце ж, біце ў звона:

Дурны мужык, як варона!..25

У вершы Мая хата здаецца, што Багушэвіч піша не толькі пра жыллё селяніна, а і пра родную хату - Беларусь:

\footnotetext{
24 Ibidem, c. 24-25.

25 Ibidem, c. 25-26.
} 
Кепска ж мая хатка, падваліна згніла, І дымна, і зімна, а мне яна міла;

Не буду мяняцца хоць бы і на замкі, Калок свой мілейшы, як чужыя клямкі. На страсе мох вырас, на маху бярозка. Мільшая мне хатка, як чужая вёска... Я не кіну хаты, хоць вы мяне рэжце, Не пайду да вас я, хіба ў арэшце.

А хоць сілай навет адарвалі 6 з дому, Калісьці вярнуўся б, як мядзведзь да лому.

Заваліцца й хата, зарастуць пакосы, Усё б я вярнуўся, хоць гол да босы! Насёк бы бярвенняў, нацягаў бы моху, Зноў бы склеціў хату як-кольвек патроху $[. . .]^{26}$

У вершы Свая зямля гучыць матыў роднай зямлі, на якой нарадзіўся і якая выратуе цябе, дзе б не быў. Навабранец у войска за тое, што не адмовіўся ад сваёй веры каталіцкай і не перайшоў у праваслаўе, быў сасланы “за тысячу міль! Вун аж куды!":

Умёр бы то, мусіць, я тут

Каб не жменька той роднай зямлі.

як пачне разбіраць і мяне, Дык шчыпту яе ў вадзе Глытнеш, дык пот аж ліне І хваробу рукой развядзе!

А другім, што даваў, дык і не! Не памог і не шкодзіў нікому, Бо зямля не па ix, а па мне.

Значы, трэба зямлі мець аж з дому [...] $]^{27}$

Выказваючы народу яго цяжкае сацыяльнае становішча, Багушэвіч паказвае, хто вінаваты ў гэтым: паны, адсутнасць асветы, несправядлівы суд. Пецярбургскі камітэт па справе друку, пазнаёміўшыся з дасланым з Часовага камітэта па справах друку ў г. Вільня, зборнікам Смык беларускі (выдадзеным у Пецярбургу ў 1907-1908 гадах) зразумеў ягоную ідэйную накіраванасць і 28 кастрычніка 1908 года данёс (пад подпісам чальца

\footnotetext{
26 Ibidem, c. 33.

27 Ibidem, c. 97.
} 
камітэта графа Галавіна) пракурору Санкт-Пецярбургскай судзебнай палаты пра небяспечнасць твораў Багушэвіча, дзе

[...] апяваюцца радасці і нягоды жыцця беларускага селяніна, а таксама апісваецца становішча паноў як класа кіруючага, багатага, які дармаеднічае і прыгнечвае земляроба-селяніна [...] супрацьставяцца адзін другому два класы, з аднаго боку - сялянская маса, паказаная паднявольнай і прыгнечанай, з другога ж паны, паказаныя жорсткімі, маральна нізкімі і грубымі людзьмі, якія выступаюць у ролі пануючага класа для эксплуатацыі безабароннага народа і для дасягнення ўласнага дабрабыту.

Камітэт па справах друку ўбачыў у вершах склад злачынства, праследуемага па пункце 6 артыкул 129 Крымінальнага ўлажэння выдання 1903 года і прасіў пракурора ўзбудзіць судовы пераслед аўтара Сямёна Рэўку (Франца Багушэвіча). У падобных словах і з такой жа высновай пісаў 24 кастрычніка 1908 года той жа Галавін пра Дуgку беларускую28.

Раней па падобных прычынах не дайшоў да друку трэці зборнік Багушэвіча - Беларускія расказы Бурачка. Віленскі асобны цэнзар 16 сакавіка 1899 года напісаў у Галоўнае ўпраўленне па справах друку:

Па сутнасці пытання ці не крыецца ў такога роду сачыненнях тэндэнцыя, акрамя "маларускай", стварыць яшчэ "беларускую" літаратуру і такім чынам разбіць і знясіліць літаратурнае і нацыянальнае адзінства, а ў выніку гэтага і палітычную магутнасць рускага народа $[. . .]^{29}$.

Багушэвіч, добра знаёмы са становішчам парэформенных вёскі і горада, не мог клікаць яго жыхароў на рэвалюцыйнае вызваленне з няволі. Ягонай задачай было іншае - паказаць народу сацыяльную і непарыўную з ёй нацыянальную несправядлівасці і навучыць народ болей не цярпець іх. Хаця ёсць у Багушэвіча і разуменне таго, што здабыць вольнасць можна шляхам барацьбы, цаною свайго жыцця. Герой верша Кепска буgзе, Аліндарка, апынуўшыся на прыродзе падчас пераходу з аднаго астрога ў другі, гаворыць:

Аж заплакаў я, здрадзеўшы!

От, здаецца б, і не еўшы

28 Цыт. па: ibidem, c. 206-207; Беларускія пісьменнікі gругой паловы XIX стагоggзя. зборнік тэкстаў, Мінск 1956, с. 318-323.

29 Беларускія пісьменнікі, с. 317-318. 
Быў бы сыты на свабодзе,

Як той кролік у гародзе.

Тут здаецца, і сканаў бы,

За свабоду жыццё б даў бы! ${ }^{130}$

А вось, што піша Багушэвіч, успамінаючы паўстанне 1794 года, у вершы Да 100-гоggзя (яго няма ў названых зборніках):

Ты прымі ад нас пашану,

О, Тадэвушавы ценю,

Абудзі ў сэрцах раны,

Павяртай іх з амярцвення.

Хай з былога ўстануць воі,

Хай на бой натхняць нашчадкаў;

Праз любоў да вольнай волі

Мы палюбім нашу Матку!

Хай цяпер, перад нягодай,

Кроў з-пад Кракава абудзіць

Сілу нацыі й народа $[. . .]^{31}$.

Багушэвіч сем гадоў супрацоўнічаў з польскамоўным часопісам "Край”, які выходзіў у Пецярбургу. Даследчык Алег Лойка піша, што "гэта быў перыяд падспуднага і канчатковага фарміравання яго як беларускага пісьменніка"32. Ягоныя допісы, змешчаныя ў раздзелах Лісты з правінцыі і Суgовыя навіны, раскрывалі гаротны стан, сацыяльную няроўнасць сялян і гарадскіх нізоў і паказвалі прычыны народнай беднасці і роспачы (антынародны характар царскай расійскай палітыкі ва ўсіх сферах жыцця, адсутнасць асветы і адукацыі народных мас, занядбанне яго мовы і культуры) ${ }^{33}$.

Паводле Нагродскага Багушэвіч па даручэнні філолага Яна Карловіча складаў беларускі слоўнік. Ён меў картачкі, на якія выпісваў пачутыя пад час размовы словы і затым складаў іх у спецыяльныя скрыначкі. Пра "Беларускі слоўнік" пісаў у артыкуле і Н. Роўба. А даследчык літаратуры А. Лойка ўказаў, што Багушэвіч займаўся ім больш за 30 гадоўз3.

30 Ф. Багушэвіч, Творы, с. 61.

31 Ibidem, c. 106.

32 А.А. Лойка, Гісторыя беларускай літаратуры, с. 252.

33 Ф. Багушэвіч, Творы, с. 133-185.

34 Пачынальнікі, с. 440, 422; А.А. Лойка, Гісторыя беларускай літаратуры, с. 248. 


\section{Заключэнне}

Думаю, што Багушэвіча смела можна прызнаць ідэолагам ці творцам беларускай нацыянальнай ідэі першай трэці XIX стагоддзя. I вельмі добрым сімвалічным фактам прызнання, што Багушэвіч быў за беларусаў, з'яўляецца адмова яго сына перадаць ім архіў бацькі ${ }^{35}$.

У выдадзенай у 1930 годзе кніжачцы Франціш Багушэвіч... А. Станкевіч пicay̆:

Добра мусіць разумее народ думкі свайго народнага Бацькі, калі, пераважна ў Заходняй Беларусі, шырокія беларускія сялянскія масы творы яго ўмеюць на памяць, якія пераходзяць з вуснаў у вусны, і калі бадай усе сучасныя беларускія старэйшыя працаўнікі на роднай ніве ўзяліся за плуг дзякуючы Dudcy і Smyku Багушэвіча, якія першыя адкрылі ім вочы на тое, што рабіць яны маюць як сыны паднявольнай Беларусі ${ }^{36}$.

Пляменніца Багушэвіча ведала ад Нагродскага, што Дуgкі беларускай было выдадзена першым тыражом тры тысячы асобнікаў і яна хутка разышлася, а другім тыражом не менш 200 (іх даставілі з Кракава ў Беларусь, а астатнія пазней, не вядома колькі), якія таксама расходзіліся хутка ${ }^{37}$. Так што жадаючыя маглі знайсці кнігі.

\section{Бібліяграфія}

Багушэвіч Ф., Творы, Мінск 1967 [Bagušèvič F., Tvory, Mìnsk 1967].

Багушэвіч Ф., Творы, уклад. і прадм. Я. Янушкевіч; камент. У. Содаль, Я. Янушкевіч, Мінск 2001 [Bagušèvič F., Tvory, uklad, pradm. Â. Ânuškevič; kament. U. Sodal', Â. Ânuškevič, Mìnsk 2001].

Беларускія пісьменнікі gругой паловы XIX стагоggзя. Зборнік тэкстаў, Мінск 1956 [Belaruskiâ pis'mennikì drugoj palovy XIX stagoddzâ. Zbornik tèkstaŭ, Mìnsk 1956]. Гарэцкі М., Гісторыя беларускае літаратуры, Вільня 1921 [Garèckì M., Gistoryâ belaruskae litaratury, Vilnâ 1921].

Кісялёў Г., Смак Беларушчыны, Мінск 2013 [Kìsâlëŭ H., Smak Belaruščyny, Mìnsk 2013]. Латышонак А., Нацыянальнасць - Беларус, Вільня 2012 [Latyšonak A., Nacyânalnasc' Belarus, Vilnâ 2012].

\footnotetext{
35 А. Станкевіч, 3 Богам ga Беларусі, с. 239.

36 Ibidem, c. 257.

37 Пачынальнікі, с. 440.
} 
Лойка А.А., Гісторыя беларускай літаратуры. Дакастрычніцкі перыяg. Паgручнік gля філалагічнага факультэта, ч. 1, Мінск 1989 [Lojka A.A., Gistoryâ belaruskaj litaratury. Dakastryčnicki peryâd. Padručnik dla filalagičnaga fakultèta, č. 1, Mìnsk 1989].

"Наша Ніва" [“Naša Niva”] 15.05.2010.

Пачынальнікі. 3 гісторыка-літаратурных матэрыялаў XIX ст., уклад. Г.В. Кісялёў, Мінск 2003 [Pačynal'nikì. Z gìstoryka-litaraturnyh matèryâlaŭ XIX st., uklad. G.V. Kìsâlëŭ, Mìnsk 2003].

Станкевіч А., 3 Богам gа Беларусі. Збор твораў, уклад., рэд., камент. А. Пашкевіч, А. Вашкевіч, Вільня 2008 [Stankevič A., Z Bogam da Belarusì. Zbor tvoraŭ, uklad., rèd., kament. A. Paškevì̌, A. Vaškevič, vìlnâ 2008].

Цьвікевіч А., Запаgно-русізм. Нарысы з гісторыі і грамаgскай мысьлі на Беларусі ў ХІХ і пачатку XX в., Менск 1929 [C'vikevič A., Zapadno-rusizm. Narysy z gìstoryi ì gramadskaj mys'li na Belarusi ŭ XIX ì pačatku XX v., Mensk 1929].

шыбека 3., Героі беларускай гісторыі ў памяці беларусаў. Да праблемы фарміравання грамаgзянскай нацыі, [у:] Новае слова у гісторыі і культуралогіi, рэд. А.А. Суша, Мінск 2012, с. 119-129 [Šybeka Z., Geroi belaruskaj gistoryì ŭ pamâci belarusaŭ. Da prablemy farmìravannâ hramadzânskaj nacyì, [u:] Novae slova ŭ gistoryi ì kul'turalogì, rèd. A.A. Suša, Mìnsk 2012, s. 119-129].

Swajak K., Fr. Bahušewič - piaśniar biełaruski, "Krynica” 1920, №2, 3, 4, 5. 


\section{Адлюстраванне месца і ролі беларускай мовы ў сістэме адукацыі як фактару фарміравання нацыянальнай ідэнтычнасці ў публіцыстыцы газеты "Nasza Niwa" ("Наша Нива") у 1906-1907 гадах}

The place and role of the Belarusian language in the education system as a factor in the formation of national identity as reflected in the 1906-1907 journalism of the newspaper "Nasza Niwa" ("Наша Нива")

The article considers the attempts to create a system of primary and higher education in the Belarusian language in 1906-1907, as reflected in the journalism of the newspaper "Nasza Niwa" ("Haшa Нива"), published in the Belarusian language in Vilnius. The newspaper voiced the concerns of the Belarusian national movement about the opening of Belarusian-language schools and universities, which was complicated by the dominance of the Russian language in the education system as well as the low level of literacy of the population of Belarus. At the same time, the journalism of "Nasza Niwa" cited the examples of Poles, Lithuanians and Ukrainians as those who solved these problems more successfully and should become role models for Belarusians.

Ke y w ord s: Vilnius, Russia, Belarusians, Belarusian language, "Nasza Niwa"

Miejsce i rola języka białoruskiego w systemie oświaty jako czynnika kształtowania tożsamości narodowej na łamach gazety „Nasza Niwa” („Наша Нива”) w latach 1906-1907

Artykuł stanowi próbę odtworzenia poglądów na system szkolnictwa podstawowego i wyższego autorów oraz wydawców ukazującej się w Wilnie w latach 1906-1907 pierwszej gazety białoruskiej „Nasza Niwa”. Na łamach periodyku relacjonowano przejawy białoruskiego ruchu narodowego oraz snuto plany otwierania szkół i uczelni z białoruskim językiem wykładowym, realizację których jednak utrudniały: dominacja języka rosyjskiego w systemie edukacji, a także niski poziom alfabetyzacji ludności Białorusi. Jednocześnie dziennikarze „Naszej Niwy” przytaczali bardziej udane przykłady 
działań Polaków, Litwinów i Ukraińców w zakresie organizacji szkolnictwa w języku ojczystym i nawoływali Białorusinów, żeby szli w ślady swoich sąsiadów.

Słowa kluczowe: Wilno, Rosja, Białorusini, język białoruski, „Nasza Niwa”

Свая нацыянальная мова для дзеячаў беларускага нацыянальнага руху', як і для прадстаўнікоў нацыянальных рухаў іншых народаў з канца XVIII стагоддзя з'яўлялася адным з найважнейшых фактараў ідэнтычнасці². у беларускім выпадку найбольш ярка сфармуляваў значэнне мовы ў лёсе народа ў 1891 годзе беларуска-польскі пісьменнік Францішак Багушэвіч: "Не пакідайце ж мовы нашай беларускай, каб не ўмёрлі!"3 Яго творчасць аказвала значны ўплыў ${ }^{4}$ на выдауццоу другой у гісторыі газеты на беларускай мове - "Нашай Нивы” (“Naszaj Niwy”), якая пачала выходзіць 10/23 лістапада 1906 года ў Вільні двума алфавітамі - рускім і польскім, прыстасаванымі да патрэб беларускай мовы. Выхад газеты ў свет супаў з перыядам Першай рускай рэвалюцыі 1905-1907 гадоў, калі народы Расійскай імперыі атрымалі магчымасць як сацыяльнага, так і нацыянальнага вызвалення5.

Праблему статусу беларускай мовы ўпершыню падняла на старонках першага нумара газеты Алаіза Пашкевіч - пад псеўданімам Мацей Крапіўка - у артыкуле Jak nam uсzусса. У гэтым тэксце аўтар, пераконваючы чытача ў тым, што беларуская мова не “chamska, brydka”, упершыню ў беларускім перыядычным друку спасылаўся на меркаванне Францішка Багушэвіча:

Szmat było takich narodoů - kaže pieśniar biełaruski Maciej Buraczok, - szto stracili napiersz mowu swaju, tak jak toj czeławiek pred skananiem, katoramu mowu zajmie, a potym i zausim zamiorli. Nie pakidajciež mowy naszej biełaruskoj, kab nie umiorli!

1 R. Radzik, Białorusini między Wschodem a Zachodem, Lublin 2012, с. 87 і наст.

2 M. Hroch, Małe narody Europy. Perspektywa historyczna, Wrocław-WarszawaKraków 2003; R. Szul, Język. Naród. Państwo. Język jako zjawisko polityczne, Warszawa 2009.

3 В. Булгакаў, Гісторыя беларускага нацыяналізму, Vilnius 2006, с. 214 і наст.

4 R. Radzik, Między zbiorowością etniczną a wspólnotą narodową. Białorusini na tle przemian narodowych w Europie Środkowo-Wschodniej XIX stulecia, Lublin 2000, c. 236 і наст.

5 А. У. Унучак, “Наша ніва" і беларускі нацыянальны рух (1906-1915 г2.), Мінск 2008; В. Корбут, Беларускае пытанне на старонках першых беларускіх газет "Наша Доля" ("Nasza Dola”) і "Наша Нива" (“Nasza Niwa”) (1906 г.), "Acta Polono-Ruthenica" 2020, t. 25, z. 3, c. 177-189. 
Paznajućj [sic!] ludziej ci pa haworcy ci, pa adziožy, chto jakuju nosić - otož haworka, jazyk i jość adzioža duszy ${ }^{6}$.

На значэнне гэтага тэксту М. Крапіўкі ўжо звярталася ўвага ў літаратуры ${ }^{7}$ У артыкуле канстатавалася тагачаснае становішча беларускага насельніцтва ў галіне асветы: "Ciomny nasz narod totejszy [sic!], ciomny mużyk - biełarus". Аўтар паставіў некалькі праблем і прапанаваў іх вырашэнне. Па-першае, гэта сацыяльная праблема: "zrazumieło i prawicielstwo, zrazumieů i narod, szto, kab palepszyć ciażkoje życcio ůsich pracujuczych, treba piersz napiersz dać im nawuku, [...] kab pasla kożny moh dobra czytać i karystać z taho, da czaho dadumalisia i szto napisali uczonyje ludzi".

Па-другое, гэта нацыянальная праблема, звязаная з дыскрымінацыяй беларускай мовы ў Расійскай імперыі: "Ūsim dobra wiedamo, szto ůžo mnoho let jak prawicielstwo prykazało, kab u narodnych szkołkach inaczej nie uczyli, jak [...] pa rasiejsku". Мацей Крапіўка піша, што гэта было зроблена з мэтай "abrusić usie narodnosci".

Па-трэцяе, адзначаў М. Крапіўка, нацыянальная праблема была пераплецена з педагагічнай і псіхалагічнай:

Tož naszy dzietki - biełarusy majuć u szkołach adrazu dwie raboty: adna rabota - heta paznać znaki-litery, nauczycca składać z ich słowy, a druhaja rabota - adnaczasnie nauczycca razumieć i hawaryć pa rasiejsku, bo u szkoli uczyciel usio tłumaczyć tolki pa rasiejsku, a hetaj mowy dzieci nie znajuć, nikoli ů chaci ad baćkoů nia czuli - jana dla ich czužaja. Woś i wychodzić, szto pakul dzicio nie paznaje rasiejskoj mowy, to u szkoli niczoho nie razumieje, szto kažeć uczyciel, i siadzić, jak baran.

3 гэтай сітуацыі прапаноўваўся наступны выхад:

Tak woś, kali pacznuć u nas ůwadzić nowyje naczalnyje narodnyje szkoły, treba kaniesznie, kab dzieciej ů ich nauczali pa biełarusku, kab tłumaczyli im usio pa tutejszamu, pa swojemu, jak dzieci haworać u chaci z baćkami i jak im najlahczej razumieć. Tady dzieci i czytać skarej nauczacca, i paznajuć lahczej inszyje mowy, rasiejsku dy polsku.

У публіцыстычным артыкуле М. Крапіўкі гучаў заклік да чытачоў “Naszaj Niwy": "Dziela taho ůsie biełarusy i ůsie, chto chocze dać narodu praudziwuju nawuku pawinny damahacca dla biełarusoů biełaruskoj naczalnoj szkoły”. Гэткім

\footnotetext{
6 Maciej Krapiůka, Jak nam uczycca, "Nasza Niwa”, 10/23.11.1906, № 1, c. 5.

7 R. Radzik, Białorusini między Wschodem, c. 87.
} 
чынам, ставілася чарговая праблема і адначасова задача - актывізацыя беларускага насельніцтва ў барацьбе за адукацыю на роднай мове.

у газеце адзначалася, што беларусы і іншыя народы ў той перыяд знаходзіліся на розных этапах вырашэння праблемы стварэння сістэмы асветы на роднай мове: "Litoůcy, palaki, žydy, ukraincy - usie zbirajucca z siłami i zawodziać swaje szkoły ů rodnoj mowi [...]. Adny my, biełarusy, niejak kiepska starajemsia ab swaich szkołach”. М. Крапіуука ўдакладняў асаблівасць беларускай сітуацыі: "[...] kataliki ciapier achwotniej pasyłajuć dziaciej da polskoj szkoły, a prawosłaůnyje - pa staramu - da rasiejskoj”.

\section{Гістарычныя прычыны непісьменнасці беларусаў}

"Nasza Niwa” адстойвала погляд, згодна з якім сістэма асветы для беларускамоўнага насельніцтва павінна была стварацца на яго роднай мове. Так, аўтар пад псеўданімам Войцех пісаў, што раней "навука не магла трапиць да народу, бо давали яе уу чужой, мало панятнай мови”. Далей Войцех сцісла апісаў становішча з асветай і літаратурай на беларускай мове ў папярэдні перыяд - у XIX стагоддзі:

Дзевятнацаты век и расейскае панаванне не прынесли ничога добраго беларусам: тоеж гнибенне и паневерка роднае мовы, такимиж замками зачынены ад свету вочы цёмнаго народу. Дарма старалися лепшые людзи таго часу - Чэчот, ДунинМарцинкевич: заместа награды цярпели яны здзек и смех люцки. - И ноч, цёмная ноч панавала ў Беларуси.

Трэбаж, найлепей зразумеў патрэбу беларускай мовы, каб трапиць да народу, Муравьёў - той самы, што ў 63 гаду кроўю залиў наш край. Ен [sic!] забараниў ўсим друкаваць па нашаму, за тоеж сам друкаваў па беларуску чорнасоценные, як их цяпер называюць, книжки. Гэтак, думаў Муравьёў, найлягчэй задурыць голаву цёмным мужыком.

Пачынаючы ад Муравьёва, пасля паўстання 1863 году, абрусицельная палитыка затрымала ўсякае развицце Беларуси. у Беларуси не было свабоды писаць и друкаваць па своему, не можна было ужываць роднай мовы уу школи, хаця бы стольки, скольки было дазволена иншым народам - прымерам палякам у Польшчы; а зноў не было ў Беларуси такога гнезда свабоднае навуки и свету, якие мели Литва (Пруская часць яе, што пад немцам), ци Украйна (Галичына у Аўстрыи $)^{8}$.

8 Войцех, Зямельная справа у Беларуси (Праgаўжэнне), "Наша Нива", 22.12.1906, № 7 , с. 2. 
Як складвалася сітуацыя ў пачатку XX стагоддзя, апісаў у серыі артыкулаў Беларуская нароgная школа Дзядзька Карусь (Канстанцін Міцкевіч). Аўтар адзначаў: "цяпер, як беларусам дали право гаварыць и писаць на сваей мови и як паявилося першае беларускае писанае слово, багата знайшлося прациўникоў беларускай мовы", "рэжэ яна вушы навэт таму ж самому беларусу, каторы выйшоў с простаго народу, интэлигенту". Публіцыст звязваў такое становішча з «характэром унутрэной расейскай казённай палитыки». У чым яна заключалася, аўтар апісваў гэтак:

Маленьки хлочык - беларус вучыцца ў школи. [...] чы чуе жэ ён свае роднае слова? Не. Ен чуе адну тольки насмешку, над сваею моваю; [...] вучыцель, а за им и ўсе вучни падымаюць яго на сьмех. [...] Таким спосабам засеваецца ненависць у душу будучаго интэлигента - беларуса к роднай мови, звычаю, парадкам. [...] И пасля сэминарскай адукации беларус часам скажэ неўмысля гдзе небудзь у кумпании беларускае слова - яму ужо брыдка.

Дзядзька Карусь звяртаўся да тых, хто высмейваў беларускую мову: "Не стае ешчэ тольки таго, каб паехали вы у Вильню и стали там на калени прэд адным памятником"9. Маецца на ўвазе помнік Міхаілу Мураўёву, віленскаму генерал-губернатару, які задушыў паўстанне 1863-1864 гадоў і пачаў новы этап русіфікацыйнай палітыкі ў Беларусі і Літве ${ }^{10}$.

Адной з прычын нізкага ўзроўню асветы насельніцтва Беларусі газета "Наша Нива" лічыла між іншым адсутнасць мясцовых вышэйшых навучальных устаноў. Гэта праблема была па сутнасці ўсерасійская, пра што сведчыла заметка з Мінска, апублікаваная уу канцы 1906 года. У ёй адзначалася, што "Минск хочэ залажыць унивэрсытэт, Вильня сабе хочэ, смаленск сабе, Саратоў сабе. [...] Мы стаим за тое, каб устроиць у нас Унивэрсытэт у Вильни, галаўным горадзе усяго нашаго краю [...]". Але ўлады не ішлі насустрач гэтым патрэбам. Газета напамінала: "У Вильне Унивэрсытэт даўней быў, але цар Микалай Першы закрыў яго у 1832 гаду”. Будучы ўніверсітэт у Вільні "Нашай Ниве" бачыўся гэткім: "Нехай у гэтым унивэрсытэце будуць учыць на усих мовах, якие у нашым краю ёсць: па расейску и па польску, па беларуску, па литоўску и жыдоўску, як хто захочэ"11.

9 Дзядзька Карусь, Беларуская нароgная школа. 2. Беларуская мова у казенной школи, "Наша Нива", 22.12.1906, № 7, с. 4.

10 D. Staliūnas, Rusinimas. Lietuva ir Baltarusija po 1863 metų, Vilnius 2009; М. Долбилов, Русский край, чужая вера. Этноконфессиональная политика империи в Литве и Белоруссии при Алексанgре II, Москва 2010.

11 “Наша Нива", 22.12.1906, № 7, с. 7. 
Зноў пра Віленскі ўніверсітэт "Nasza Niwa” ўспомніла ў лістападзе 1907 года ў сувязі з развагамі пра тое, што непісьменнасць беларусаў - гэта не імі створаная праблема:

Ale nie my samy winawaty ū hetym: byū daūniej i ū Wilni uniwersytet, kudy ūsia Litwa i Biełaja Ruś pasyłali synoū swaich na nawuku, atkul wychodziła nie mała wuczonych i słaūnych ludziej. I hety uniwersytet zakryli...

S taho czasu ūsie naszy tutejszyje ludzi, žednyje [sic!] nawuki, musiać jechać ū Rasieju, a tam paznawać rodnuju staronku, ūsie patreby i sprawy jaje - wielmi trudna ${ }^{12}$.

Такім чынам, менавіта дзейнасць расійскага ўрада ў нядаўнім мінулым і ў сучаснасці разглядалася як першапрычына як нізкага стану асветы ў Беларусі, так і адсутнасці беларускамоўнай сістэмы адукацыі.

Ва ўмовах Першай рускай рэвалюцыі актывізаваліся контррэвалюцыйныя рускія нацыяналістычныя элементы, якія паўсталі на абарону дарэвалюцыйных парадкаў, фактычна - ранейшай расійскай нацыянальнай палітыкі, накіраванай на дыскрымінацыю нярускіх народаў Расійскай імперыі, г.зв. “инородцев". Сярод такіх арганізацый, якія дзейнічалі ў Беларусі, быў Саюз рускага народа. У красавіку 1907 года, пішучы пра праблему рускага нацыяналістычнага руху ў Беларусі (“jość ŭ Rasiei žmienia ludziej, katoryje nazywajuć siabie «istinno-ruskimi», a narod ich klicze "czornaja sotnia»"13), "Nasza Niwa" адзначала, што "hetyje «ludzi» ckujuć adzin narod na adzin, ruskich na žydoŭ dy palakoŭ”. Разам з тым у артыкуле канстатавалася аналагічная тэндэнцыя і з боку тых, каго газета называла "istinno-polskije ludzi”. Гэта праблема асвятлялася ў тым ліку ў сувязі з пытаннем аб тым, на якой мове павінны размаўляць і атрымліваць адукацыю беларусы. "Nasza Niwa" рэзюмавала:

Wiedama, treba i warta kožnamu wuczycca i pa-polsku, i pa-rusku, i jeszcze pa jakomu, a tak sama czytać i polskije, i inszyje knižki, dy brać z ich toje, szto jość dobraje i karystnaje. Alež niechaj palak astajecca palakom, ruski - ruskim, biełarus - biełarusom, dy ŭsie niechaj žywuć u zhodzi i spakoju, bož ǔsie ludzi - braty.

Гэты тэзіс з таго часу стаў пастаяннай формулай у ідэалогіі беларускага нацыянальнага руху па пытанні беларуска-руска-польскага суіснавання на землях Беларусі. Але рэчаіснасць была іншая, неспрыяльная для ажыццяўлення такіх дэмакратычных па сутнасці ідэй. Так, у жніўні 1907 года

12 Ukrainskaja mowa u uniwersytetach, "Nasza Niwa", 10/23.11.1907, № 33, c. 3-4.

13 Wilnia 13(26) apryla, "Nasza Niwa", 1907, № 15, c. 1. 
"Nasza Niwa” з трывогай паведамляла пра з'езд Саюза рускага народа, які адбыўся ў Маскве: "Abjawiŭ źjezd i toje, jakoha «dabra» choczuć czornasociency dla naroda. Szkoły, pa ichniamu, pawinny być nacjonalnyje rasiejskije, dy pad dahladom duchowienstwa i czynoŭnikoŭ kazionnych, kab i duchu swabodnaho ŭ ich nie było"14.

Інакш кажучы, беларускія нацыянальныя дзеячы не маглі разлічваць на дапамогу з боку ўлад Расійскай імперыі ў пытанні стварэння сістэмы беларускамоўнай адукацыі. I сапраўды, першыя школы з выкладаннем на беларускай мове з'явіліся ў Вільні толькі падчас нямецкай акупацыі, у Першую сусветную вайну: 27 кастрычніка 1915 года была ўведзена забарона ва усеёй зоне акупацыі на выкладанне ў школах па-руску. 13 лістапада 1915 года першая беларуская школа была адкрыта ў Вільні пры актыўным удзеле А. Пашкевіч, што, мабыць, невыпадкова, улічваючы яе заклапочанасць гэтым пытаннем з 1906 года' ${ }^{15}$.

\section{Сацыяльныя прычыны непісьменнасці беларусаў}

У рэдакцыі газеты “Nasza Niwa” ўсведамлялі, што праблема асветы ў Беларусі шчыльна звязана з яе даступнасцю беларускамоўнаму насельніцтву, што можна было забяспечыць толькі на яго роднай мове. Рэдакцыя лічыла, што народ "skarej nas zrazumieje, kali my budziem pisać u naszaj rodnaj biełaruskaj, jak szmat chto kaže - «mužyckaj» mowi”'16. Далей адзначалася, што для дасягнення гэтай мэты існуе сур'ёзная перашкода: "Z pamiež usich Eưropejskich hasudarstw Rasieja najmieńsz maje nawuki, najbolsz ciomnaja, a da najciemniejszych czaściej jaje naležyć i Biełaja Ruś".

Аналізуючы даныя Першага ўсеагульнага перапісу насельніцтва Расійскай імперыі 1897 года з дзвюх губерняу - усходняй Магілёўскай і заходняй Гродзенскай ${ }^{17}$, складваецца карціна, якая дэманструе не толькі нізкі ўзровень пісьменнасці ў Беларусі, але і нераўнамернасць размеркавання пісьменных і непісьменных людзей у розных яе частках.

${ }^{14}$ Zjezd tak-zwanaho "Sojuza Russkaho Naroda", "Nasza Niwa", 3/16.08.1907, № 26, C. 2 .

15 У. Ляхоўскі, Школьная аgукацыя ў Беларусі паgчас нямецкай акупацыі (19151918 ге.), Vilnius-Białystok 2010, c. 77, 119.

16 "Nasza Niwa", 17/30.11.1906, № 2, с. 2.

17 Документы и материалы по истории Белоруссии (1900-1917 г2.), т. 3, ред. В.Н. Перцев, И.С. Кравченко, Е.П. Лукьянов, А.И. Воронова, Минск 1953, с. 260-261. 
Т а б л і ца 1. Узровень пісьменнасці жыхароў Гродзенскай і Магілёўскіх губерняў Расійскай імперыі (1897 г.)

\begin{tabular}{|c|c|c|c|c|}
\hline \multirow{3}{*}{ Саслоўі } & \multicolumn{4}{|c|}{$\begin{array}{c}\text { Працэнт пісьменных у адносінах да агульнай колькасці } \\
\text { насельніцтва }\end{array}$} \\
\hline & \multicolumn{2}{|c|}{ Мужчыны } & \multicolumn{2}{|c|}{ Жанчыны } \\
\hline & $\begin{array}{l}\text { Гродзенская } \\
\text { губерня }\end{array}$ & $\begin{array}{l}\text { Магілёўская } \\
\text { губерня }\end{array}$ & $\begin{array}{l}\text { Гродзенская } \\
\text { губерня }\end{array}$ & $\begin{array}{l}\text { Магілёўская } \\
\text { губерня }\end{array}$ \\
\hline Дваране & 76,53 & 62,99 & 73,91 & 53,50 \\
\hline Духавенства & 82,04 & 80,15 & 76,08 & 71,78 \\
\hline $\begin{array}{l}\text { Ганаровыя } \\
\text { грамадзяне }\end{array}$ & 51,90 & 48,52 & 34,79 & 29,04 \\
\hline Сельскія саслоўі & 33,01 & 19,89 & 12,26 & 2,44 \\
\hline $\begin{array}{l}\text { Тыя, хто не } \\
\text { належыць да } \\
\text { вышэйпералічаных } \\
\text { саслоўяў }\end{array}$ & 50,87 & 39,89 & 40,39 & 23,21 \\
\hline $\begin{array}{l}\text { Замежныя } \\
\text { падданыя }\end{array}$ & 54,67 & 62,79 & 55,68 & 62,50 \\
\hline Усе саслоўі & 38,36 & 25,80 & 19,61 & 8,42 \\
\hline
\end{tabular}

Сярод усіх саслоўяў, не лічачы замежных падданых, у Гродзенскай губерні працэнт пісьменных быў вышэйшы, чым у Магілёўскай. А калі ўлічыць, што асновай беларускамоўнага насельніцтва, а значыць, і асноўнай мэтавай аўдыторыяй беларускамоўнай газеты "Наша Нива" з'яўляліся сельскія саслоўі, г.зн. людзі, якія маглі зразумець яе змест, то з даных статыстыкі вынікае, што ў Гродзенскай губерні такіх патэнцыяльных чытачоў было 33,01\% насельніцтва сярод мужчын і 12,26\% сярод жанчын, а ў Магілёўскай адпаведна $19,89 \%$ і 2,44\%.

Паводле даных за 1897 год колькасць пісьменных складала: ад 11,9\% (Сенненскі пав.) да 51,8\% (г. Орша) - у Магілёўскай губерні, ад 12,1\% (Мазырскі пав.) да 49,1\% (г. Мінск) - у Мінскай, ад 11,2\% (Гарадоцкі пав.) да 39,7\% (г. Лепель) - у Віцебскай, ад 17,8\% (Кобрынскі пав.) да 57,6\% (г. Ваўкавыск) - у Гродзенскай, ад 19\% (Вілейскі пав.) да 52,8\% (г. Ліда) у Віленскай ${ }^{18}$.

18 Ibidem, c. 23-25. Даныя статыстыкі ўлічваюць тэрыторыю ў граніцах БССР 1953 г., якія адпавядаюць сучасным граніцам Рэспублікі Беларусь. 
У 1905 годзе колькасць пісьменных, не лічачы дзяцей да дзевяцігадовага ўзросту, складала: 22\% - у Магілёўскай губерні, 24\% - у Мінскай, 33\% у Віцебскай, па 38\% - у Гродзенскай і Віленскай ${ }^{19}$.

Інакш кажучы, трохі больш за трэць насельніцтва на захадзе Беларусі, і менш за чвэрць - каля трэці насельніцтва ў цэнтры і на ўсходзе Беларусі магла разглядацца як патэнцыяльная аўдыторыя любой літаратуры, у тым ліку прэсы. Аднак даныя па сельскай мясцовасці, пераважна беларускамоўнай, паказваюць, што там колькасць пісьменных вар'іравалася ад 11-12\% на ўсходзе (Сенненскі, Мазырскі, Гарадоцкі пав.) да 17-19\% на захадзе (Кобрынскі, Вілейскі пав.). Такім чынам, сярод сельскага насельніцтва колькасць патэнцыяльных чытачоў першых беларускамоўных газет у першыя гады іх выхаду не перавышала 11-19\%.

Па сутнасці, стаяла пытанне не толькі пра стварэнне сістэмы беларускамоўнай адукацыі, але ўвогуле пра ліквідацыю непісьменнасці сярод насельніцтва Беларусі. Гэта праблема знайшла адлюстраванне і ў творчасці тады пачынаючых, а ў будучыні вядомых беларускіх паэтаў - Якуба Коласа і Янука (Янкі) Купалы.

У вершы Pieśnia kale kałyski, апублікаваным у красавіку 1907 года, якуб Колас (Канстанцін Міцкевіч), апісваючы долю немаўляці, быццам бы падказваў яму:

Szto ciabie czekaje, syn?

Szto twaja za dola? [...]

A mo pojdziesz ŭ szkołu ty,

Budziesz czaławiekam.

Biez wuczennia kiepska žyć

Hetym trudnym wiekam ${ }^{20}$.

У вершы Wuczysia!.., апублікаваным у жніўні 1907 года, Янук Купала (Ян Луцэвіч) заклікаў беларусаў да навукі:

Wuczysia, niabože, wuczeńnie pamože

Zmahacca z niadolej, z niawolej...

Szto muczyć siahońnia, szto dumki trywože,

- Zbiažyć i nia prydzie nikoli! [...]

19 Ibidem, c. 269.

20 Jakub Kołas, Pieśnia kale kałyski, "Nasza Niwa”, 20.04.1907, № 16, c. 1. 
Ǔsie ludzi znaczeńnie paznali wuczeńnia,

Adzin tolki ty ani dbajesz!

Ciamniej, biełarusie, ty noczki asienniaj

I szczaście-ž takoje ty majesz... ${ }^{21}$

Газета "Наша Нива" не раз выказвала спадзяванне на перамены у грамадска-палітычным жыцці Расійскай імперыі, якія прывядуць і да рэформ у сістэме адукацыі:

Ciapier možna mieć nadzieju, szto z nowymi paradkami pojdzie skroś i pa naszym kraju świet nawuki, szto i nasz ciomny biełarus praczniecca ad ciažkaho snu i paznaje ū sabie czaławieka [kypciy̆ "Naszaj Niwy" - B. K.]. Može tady i my paczujem "wialikaje słowa nawuki ū rodnaj mowie", i taja nawuka pamože pazbycca kryūd i ucisku $[\ldots . .]^{22}$.

У жніўні 1907 года карэспандэнт Adzinoki (К. Міцкевіч) паведамляў з Бяларуч Мінскага павета пра недахоп кадраў для пашырэння асветы:

Inteligencii - ludziej wuczonych u naszej staranie mała, a jakaja jość, dyk i taja nia chocze ni k czamu ruki prykładać, kab choć trochi praświatlić dolu pracowitoj biednaty. Za toje-ž ŭ narodzi ciemnota wialikaja. Knižki dobraj ci hazety ni u kaho i nie ubaczysz. Zamiest sabracca da jakoha razumniejszaho i bywalszaho czaławieka dy pahutaryć ab swajej doli-niadoli, ab ciapierasznim žycciu, ciahajucca ludzi pa sudoch, dyj ab dachodzie manapolki nie zabywajucca²3.

Карэспандэнт Bierebiendzia са Слонімскага павета адзначаў яшчэ адну крыніцу невуцтва - п'янства: "A jeszcze bieda: szkoł u nas na Biełarusi mała, szmat tolki manapolek; dzieci rastuć u ciemnoci"24. Пра тое ж сведчыла і карэспандэнцыя M. Szpektara з мястэчка Дунілавіч Вілейскага павета, які пісаў у ліпені 1907 года:

U nas i wakruh miasteczka nadta ciomny narod. [...] Hetuju zimu za toje było harełki szmat i kazionnaj, i samatužnaj, tak szto pili mužyki, pili baby, pili dzieǔki. Kažuć staryje sumiennyje ludzi, szto daŭniej ŭ wioskach Kalitach, Jabłoncach, Załoŭkach, Darewie, Łatygoli hetaho nie rabili, a ciapier dyk nia daj Boh szto robicca. [...] Biełarusy - narod

21 Januk Kupała, Wuczysia!.., "Nasza Niwa”, 17/30.08.1907, № 27, c. 1.

22 Ukrainskaja mowa u uniwersytetach, "Nasza Niwa", 10/23.11.1907, № 33, c. 4.

23 Adzinoki, Z m. Biełaruczy Minskoj h. i u., "Nasza Niwa", 17/30.08.1907, № 27, c. 7.

24 Bierebiendzia, Słonimski pawiet, "Nasza Niwa", 20.07.1907, № 25, c. 7. 
pakinieny, swaich synoŭ wuczonych mała maje. U niekatorych tolki wioskach jość adzin-dwa hramatnych; jany ŭ niadzielu sabiarucca czasam paczytać hazetu, knižku, ale hetakich wiosak jaszcze mała ${ }^{25}$.

У карэспандэнцыі з вёскі Мікалаеўшчыны Adzinoki ў верасні 1907 года, пішучы пра мясцовую старую школу, параўноўваў яе стан з суседняй новай "манаполькай":

Usiaki raz, jak zirknu ja na hetu szkołu, to ŭspomniu biełaruskuju pocztowuju atkrytku "Parobkowa dworowaja chata", i wierszy M. Buraczka:

"A kiń wokam na chatu maju:

I ciacze i hnije i krywaja.

U siaredzinie hnoj i staić na hnaju.

I dziŭlusia ja sam jak trywaje"26.

Апісваючы выгляд школы, Adzinoki такім чынам характарызаваў матэрыяльную частку тагачаснай сістэмы адукацыі:

Bolsz za 40 hod žywie ŭ nas szkoła. Wywieska na jej ablezła, bukwy ścierlisia na paławinu, razmylisia daždžom, a zamiež arła czarnieje adna plama jak zharanaja hreckaja aładka. Szyby u woknach wybity, pakołany. Barwiennia [sic!] pahnili [sic!] praz ścieny možna kułak usunuć. Ganak zhniŭ, dwa słupy struchleli. Dach wahnuŭsia, abros siwym mochom. [...] Ů padłodze nima ni wodnaj ciełaj [sic!] doski. Ǔsia jana na jamach i dzirkach, jak hreblia [sic!]. Piecz pakałołasia, razjechałasia jak rezginy.

Магчыма, што непасрэдным водгукам на гэту публікацыю стаў верш Янука Купалы Na szto? у наступным нумары "Naszaj Niwy" - за 28 верасня 1907 года з прысвячэннем: "Paświaszczaju Jakubu Kołasu"27. Верш прысвечаны непатрабавальнасці беларусаў да саміх сябе:

Na szto chleb, na szto bahacie,

Kali nam miakiny chwacie?

Na szto boty czarawiki,

Kali jość łaza i łyki? [...]

25 M. Szpektar, M. Duniłowiczy. Wilejskaho pawietu Wil. hub., "Nasza Niwa", 20.07.1907, № 25, c. 6-7.

26 Adzinoki, s. Mikałaeūszczyna Minskaj hub., "Nasza Niwa", 14/2.09.1907, № 29, c. 6.

27 Januk Kupała, Na szto? (Paświaszczaju Jakubu Kołasu), "Nasza Niwa”, 28.09.1907, № 30 , c. 2. 
Na szto lek na hore, bolki,

Kali majem manapolki?

Na szto znaci ŭsiaho mnoha?

I tak trapim da astroha!..

У кастрычніку 1907 года, пішучы пра працоўную эміграцыю "z naszaj Biełarusi i Litwy", газета "Nasza Niwa” адзначала ўзаемасувязь праблем адукацыі і занятасці:

U nas že szkoł usielakich saūsim mała - świetu nawuki nie prybywaje, ziamli - tak sama. Pajszoŭ by nasz biełarus kudy-niebudź na zarabotki - dyk žež nima hdzie. Fabryk u nas mała, swaich bahaczoŭ, kab adkrywali ich, ŭ Rasiei tak sama nia szmat. A zahranicznyje bahaczy-kapitalisty - naprykład amerykanskije - pry ciapierasznich paradkach ŭ Rasiei jechać z hraszyma dy zawadzić swaje fabryki i zawody - bajacca. [...]

Woś jakije pryczyny taho, szto i nasz biełarus nia može pa ludzku nastroić žyćcio swaje. Nia dziwa, szto uciekaje jon z rodnaho kraju²8.

У гэтай публікацыі адзначаецца яшчэ адна важная праблема - эміграцыя беларусаў, выкліканая рознымі прычынамі, але ў тым ліку немагчымасцю рэалізаваць свае здольнасці на бацькаўшчыне. У гэтым кантэксце важна адзначыць немагчымасць беларускамоўнаму чалавеку атрымаць адукацыю і павысіць свой статус у тагачасным расійскім грамадстве без авалодання рускай мовай, пра што ў цытаваных вышэй тэкстах пісала "Nasza Niwa".

\section{Прыклад суседніх народаў для вырашэння праблемы непісьменнасці беларусаў}

У кастрычніку 1907 года карэспандэнт з Саколкі Гродзенскай губерні, параўноўваўваючы ўзровень грамадзянскай свядомасці і асветы мясцовых праваслаўных і католікаў, з аднаго боку, і яўрэяў, з другога, прызнаваў: "Mała nawuki u nas, mała uczyliszcz, nima bibliotek, nie czytajuć hazet. Žydy tyje bolej abrazowany i razumiejuć palityku"29.

чытачы "Naszaj Niwy" дзяліліся рознымі ідэямі, як вырашыць праблему непісьменнасці беларусаў. Чытач Янка Белы ў канцы 1906 года пісаў пра

28 Ab pierasielenniu, "Nasza Niwa", 12/25.10.1907, № 31, c. 2.

${ }^{29}$ Baūtruk, h. Sokołka Hrodziensk. hub., "Nasza Niwa", 12/25.10.1907, № 31, c. 6. 
тое, што "na hranicy Polszczy i Litwy", дзе ён жыў, "pryhladaůsia, jak palaki atkrywajuć swaje szkoły": "U Warszawie jany ustroili kołka pad nazwanniem: «Macierz Polska»"30. Аўтар прыводзіў польскі прыклад і прапаноўваў пераймаць яго беларусам: "załažyć szkoły na rodnym swaim jazyku, jak dla małych, tak i dla wialikich", "załažyć swaju: «Matku Biełaje Rusi»" - "i tahdy my zawiadziem swaje szkoły z naszym rodnym biełaruskim jazykom".

У пасляслоўі да гэтай публікацыі рэдакцыя "Naszaj Niwy” прапаноўвала чытачам на пастаяннай аснове выказвацца ў газеце па праблемах стварэння беларускай нацыянальнай школы.

У сакавіку 1907 года ў артыкуле Ab nacjonalizacji szkoły. (Hołas wuczyciela-biełarusa), падпісаным псеўданімам Narodny Wuczyciel ${ }^{31}$, аўтар, спасылаючыся на падзеі Першай рускай рэвалюцыі, адзначаў: "Tolki blisnuli «dni swabody», jak ǔsie narody ŭ Rasiei na pierszaje miesco pamiež mnohich swaich damahannioŭ pastawili trebowannie nacjonalizacii szkoły”. Публіцыст тлумачыў: "А samym pierszym i kaniecznie patrebnym warunkam dla narodnaho praświetlennia jość nacjonalnaja szkoła, heta znaczyć, szto ŭ szkoli pawinny wuczycca rodnaje mowy i ŭsie nawuki pawinny tłumaczycca paniatnaju hutarkaju [...]". Аўтар артыкула ўдакладняў, што "tolki tahdy skonczyŭszyje szkołu dzieci nia buduć zabywać hramaty i samaja hramata budzieć szczyraju pamocznicaju ǔ žyćciu, - jak szkoła u nas budzieć nacjonalnaja”. Публіцыст з надзеяй пісаў: "U aposzni hod ruskaje prawicielstwa jak-by adkazałosia ad abrusieńnia szkoły". Аднак Narodny Wuczyciel разумеў, што навучання ў школах на нацыянальных мовах удаецца дабіцца толькі там, "hdzie narod sam nia spaŭ, a, družna ŭzniaŭszysia, adwajewaŭ sabie nacjonalnuju szkołu":

Chto bolaj damahaŭsia, toj bolaj i pałuczyŭ. Ŭ Polszczy i ŭ Litwie dzieci wuczacca u swaich mowach, a heta zatym, szto tamaka ǔwieś narod, damahajuczysia mnoha czaho druhoha, ŭsio taki zawichnuŭsia na-sam-pierad zabrać ŭ swaje ruki szkołu. Szyrokaja rabota za nacjonalizaciju szkoły idzieć ciapier na Ukrainie, abo ŭ Małorosii.

Публіцыст выказваў спадзяванне, "szto nieŭzabawie buduć ukraincy trymać swaju szkołu ŭ swaich rukach", "szto rabota ukraincoŭ nie astaniecca niezauwaženaju i u nas, ŭ Biełarusi. Para i nam skazać swaje słowa, patrebawać biełaruskaj szkoły".

30 Janka Biełyj, Biełaruskaja Narodnaja szkoła. Pisulka da Redakcji, "Nasza Niwa", 2/15.12.1906, № 4, c. 5-6.

31 Narodny Wuczyciel, Ab nacjonalizacji szkoły. (Hołas wuczyciela-biełarusa), "Nasza Niwa", 16/29.03.1907, № 11, c. 3-5. 
Такім чынам, узорам для вырашэння праблемы выкарыстання беларускай мовы ў сістэме адукацыі з'яўляліся для рэдакцыі "Naszaj Niwy" палякі, літоўцы і ўкраінцы.

Неўзабаве "Nasza Niwa" апублікавала ліст чытача пад псеўданімам Filimon M. з водгукам на артыкул Narodnaha Wuczyciela. Filimon M. пагаджаўся з папярэднім публіцыстам: "Tak, nam treba damahacca biełaruskaj szkoły, kab dzietki naszy mahli wuczycca na naszaj rodnaj mowi, kab jany wiedali, szto jany biełarusy"32. Filimon М. прапаноўваў (фактычна на польскі ўзор) "arhanizawać supołku - «Matku Biełaruskuju». [...] A tady - zahlanieć sonce ŭ kožnaje wakonce!" Filimon M. заклікаў: "Nadta było by dobra, kab Redakcija «N. N.» bolej zaniałasia hetaj światoj sprawaj i kliknuła na ŭsie czatyry storany świeta".

У гэтым кантэксце відавочна, што малады беларускі нацыянальны рух у 1907 годзе ўсё яшчэ адставаў у галіне распаўсюджвання асветы на роднай мове ад аналагічных рухаў суседніх нярускіх нацыянальнасцей.

Надзею на стварэнне сістэмы вышэйшай адукацыі на беларускай мове даваў беларусам украінскі прыклад. У лістападзе 1907 года “Nasza Niwa” пісалаз3:

Na Ukrainie (abo, jak kažuć, ū Małorosii) jość dwa uniwersytety. Wuczacca ū ich najbolsz ludzi tamtejszyje - ukraincy, ale wuczać ich ūsiaho ū rasiejskaj mowie, jak ū inszych miescoch. Ciapier ukraincy dabilisia taho, szto ū hetych dwuch uniwersytetach zawiali nowyje nawuki, kab studenty paznawali i swoj rodnyj kraj - Ukrajnu, jaho historyju, literaturu (znaczyć, twory narodnych pieśniaroū i ukrainskich pisacieloū). I ab Ukrainie wuczać pa ukrainsku - ū rodnaj mowie mužykoū tamtejszych, katoryje da aposznich czasoū, jak i naszy biełarusy, uwažali swaju mowu za brydkuju, "chamskuju", niepryhodnuju da nawuki. 28 sienciabra (wiereśnia) ū Charkowie ū Uniwersytecie studenty pierszy raz słuchali lekciju, pa-ukrainsku. Prafesor Snmcoū [sic!] dawodziū sabraūszymsia na lekciju, szto kab uparadkawać žyccio ukrainskaho naroda i ūsie sprawy jaho, treba stac na mocny hrunt, a hety hrunt - narodnaja mowa i nawuka ū rodnaj mowi.

Беларускае выданне прапаноўвала разгледзець сітуацыю з вышэйшай адукацыяй у Беларусі праз прызму ўкраінскага прыкладу:

Hledziaczy na toje, da czaho dajszli naszy braty - ukraincy, czaławiek paczynaje wieryć, szto i naszy biełarusy, nasza rodnaja mowa nia zhinuć darma. Praūdy [sic!], szto u nas szkoł swaich nima - tolki ciapier atkrywajuć ich pamaleńku, dyj u naszym

\footnotetext{
32 M. Filimon, List da redakcii, "Nasza Niwa", 30.03/12.04.1907, № 13, c. 8.

33 Ukrainskaja mowa u uniwersytetach, "Nasza Niwa", 10/23.11.1907, № 33, c. 3-4.
} 
nieszczasnym kraju nia tolki biełaruskich, a ūsielakich szkoł saūsim mała; narod ciomny, jak taja tabaka ū tabakiercy ${ }^{34}$.

Такім чынам, "Наша Нива" лічыла актуальнай задачай развіццё ў Беларусі сістэмы адукацыі не толькі на беларускай, але і на іншых мовах мясцовых нацыянальнасцей, заклікала чытачоў не цурацца іншых моў - польскай і рускай, у прыватнасці, з мэтай павышэння ўзроўню асветы насельніцтва. У ліпені 1907 года "Nasza Niwa” звярнулася да чытачоў з заклікам "adkrywać biblioteki u miasteczkach i wioskach", што разглядаліся як адны з цэнтраў распаўсюджвання асветы. Газета апублікавала адпаведную інструкцыю. Выданне адзначала: "Dla adkryćcia biezpłatnaj narodnaj biblioteki-czytalni treba dastać razreszennie hubernatora. [...] Ŭ «Naszaj Niwie» my jeszcze napiszem, [...] jakije knižki treba mieć ŭ bibliotecy ŭ ruskaj, polskaj i biełaruskaj mowach, hdzie i jak možna ich dastać"35.

\section{Стварэнне Беларускага вучыцельскага саюза і ідэя адкрыцця беларускамоўных школ}

17 мая 1907 года Дзяржаўная Дума Расійскай імперыі "skasawała try [...] zakony", сярод ix - "zakon, szto praz doŭhije hody nie dawaŭ ŭ naszym kraju swabodna szyryć nawuku i świet miež narodam. Napisany jon byŭ ǔžo daŭno dla 9 hubernij Biełarusi, Litwy i Polszczy i karaŭ za tajnaje nawuczannie dziaciej"36. Гэта магло стаць стымулам для настаўнікаў у Беларусі арганізавацца. "Nasza Niwa" паведамляла: "25 maja ŭ horadzie Wilni byŭ Zjezd narodnych biełaruskich wuczycieloū. Zjezd ufundawaŭ «Biełaruski wuczycielski sajuz»". Адной $з$ мэт саюз паставіў: "Ǔwadzić ŭ szkołu abuczennie na rodnaj biełaruskaj mowie"37.

У наступны раз пра Беларускі вучыцельскі саюз газета паведамляла ў жніўні 1907 года:

U Wilejskim pawieci u proszłym tydniu byŭ zjezd gruppy narodnych wuczycieloŭ z hetaho pawietu. Najbolsz hawaryli ab nawuczanniu biełaruskich dziaciej u narodnych szko-

34 Ibidem, c. 4.

35 Jak adkrywać biblioteki u miasteczkach i wioskach, "Nasza Niwa", 20.07.1907, № 25, c. 5 .

36 Wilnia 25 maja, "Nasza Niwa", 25.05.1907, № 20, c. 1.

37 Z Biełarusi i Litwy. (Ad naszych korespondentoŭ), "Nasza Niwa", 8/21.06.1907, № 22, c. 6 . 
łach. Ǔsie pryznali, szto szkoły pryniasuć dzieciam kudy bolsz karyści, kali wuczyć ich buduć paczynać pa-biełarusku, jak jany prywykli hawaryć z baćkami u chaci; ciapier dzieciam wielmi ciažka paznawać u szkoli adrazu i nieznajomyje nawuki, i niepaniatnuju mowu. Kazali, szto biełaruski mužyk liczyć rodnuju mowu swaju za "chamskuju", drennuju, brydkuju; dyj praz heta u siabie [sic!] nie baczyć czaławieka, a tolki "chama". Dyk treba pakazać naszamu mužyku, szto jaho mowa - tak sama ludzkaja i dobraja, jak ŭsie inszyje; szto i sam jon nie "cham", a czaławiek. A jeszcze hawaryli, szto jak naszy biełarusy dzielacca na katalikoŭ i prawasłaŭnych, to z hetaho karystajuć czornasociency i ŭsie worahi świetu i swabody naroda i siejuć nienawiść i swarku miež prawasłaŭnymi i katalikami biełarusami, ckujuć adnych na adnych. Woś i treba pakazać naszym "tutejszym", szto jany ŭsie biełarusy, syny adnoj maci-ziamli Biełaruskaj. Kab szyryć hetakije dumki, kab dabiwacca nawuczannia dziaciej u paczatkowych szkołach pa-biełarusku, kab dabicca pierastrojki usiaho narodnaho abuczennia na karyść narodu i kab palepszyć žyccio wuczycieloŭ, - usie sabraŭszyjesia na zjezd pastanawili pryłuczycca da Biełaruskaho Uczycielskaho Sajuza ${ }^{38}$.

Стварэнню Беларускага вучыцельскага саюза папярэднічала спроба Канстанціна Міцкевіча і іншых настаўнікаў пачатковых школ, якія сабраліся на бацькаўшчыне Міцкевіча, у вёсцы Мікалаеўшчыне пад стоўбцамі, арганізавацца і далучыцца да Усерасійскага саюза настаўнікаў і дзеячаў народнай адукацыі (Всероссийский союз учителей и деятелей по народному образованию). Затым група настаўнікаў правяла вышэйзгаданы з'езд у Вільні. Аднак шырокай дзейнасці Беларускі вучыцельскі саюз так і не разгарнуў у сувязі з наступствамі задушэння заваёў Першай рускай рэвалюцыі падчас г.зв. сталыпінскай рэакцыі, якая звязваецца з роспускам 3 чэрвеня 1907 года II Дзяржаўнай Думы Расійскай імперыіз3.

У жніўні 1907 года ў рубрыцы Pacztowaja skrynka газета інфармавала чытача Ар. з Івянца, як і ўсіх сваіх падпісчыкаў:

Ǔ Wilenskim Wuczebnym Okruhu možna adkrywać szkoły i katalikom, ale tolki biełaruskaho "proischoždienija". Hetaje biełaruskaje "proischoždienije" treba dawiaści, i dla hetaho dosi budzie, kali, naprykład, dwa jakije wiadomyje prawicielstwu czaławieki padćwierdziać, szto ty biełarus. U praszeńniu adrazu nie piszycie, szto buduć wuczyć ŭ szkoli i pa-polsku; jak adkryjecca szkoła, tady niachaj baćki wucznioŭ padaduć ab hetym praszeńnie ad siabie, i im lahczej dazwolać ${ }^{40}$.

38 H., [U Wilejskim pawieci...], "Nasza Niwa”, 17/30.08.1907, № 27, с. 6.

39 У. Ляхоўскі, Ag гоманаўцаў ga гайсакоў. чыннасць беларускіх малаgзёвых арганізацый у 2-й палове XIX - 1-й палове XX ст. (ga 1939 г.), Vilnius-Białystok 2012, c. 40.

40 Pacztowaja skrynka, "Nasza Niwa", 17/30.08.1907, № 27, с. 8. 
Аднак, як вядома, практычных вынікаў гэтыя парады не мелі.

Сярод практычных парад па стварэнні сістэмы беларускамоўнай адукацыі на старонках "Naszaj Niwy" гучалі і эмацыянальныя заклікі. У маі 1907 года ў публіцыстычным артыкуле Васіля Васілька Piawun-hawarun ${ }^{41}$ аўтар, выступаючы ад імя пеўніка, звяртаўся да беларуса:

"Kukareku", "Biełarusie! Pieśniaj ciabie swajej haniu... Bo prajšoŭ čas... ab prymusie nie čuwać, dzie ni zirnu... [...]

Kukareku!.. rodnu mowu wy lubiciemie [sic!] da wieku.

Biełaruś naša narodam tahdy stanie ǔsia ličycca, i nad škołak dobrym płodam budzie kožny z was dziwicca.

Ach, žadaju twajmu kraju woli, lepšaje aświety. Biełarusie, adazwisia! [sic!] dzie padzieǔsia, bratka, dzie ty?!"

Усе спробы па стварэнні беларускамоўнай сістэмы адукацыі ў той час былі падпольныя. Лічыцца, што першая беларуская школа была створана К. Міцкевічам яшчэ зімой 1906 года ў леснічоўцы Смалярня Ігуменскага павета. У 1908 годзе памешчык Канстанцін Гардзялкоўскі запрасіў К. Міцкевіча выкладаць у беларускамоўнай школе, адкрытай ім у вёсцы Сані Сенненскага павета. У тым жа годзе расійскія уулады закрылі шэсць таемных беларускіх школ на Лідчыне. Такі ж лёс напаткаў падпольныя школы на Лідчыне і ў Новай Вілейцы ў 1911 годзе, да адкрыцця якіх мелі адносіны Алаіза Пашкевіч і Уладзіслава Станкевіч. Як адзначае Уладзімір Ляхоўскі, “пачынанні малалікай беларускай нацыянальнай эліты ў арганізацыі нацыянальнага школьніцтва тады не знайшлі масавай падтрымкі уу жыхарства"42. Аднак варта ўдакладніць, што і рэсурсаў для развіцця сістэмы школьнай адукацыі на беларускай мове ў "беларускай нацыянальнай эліты" проста не было, а расійская дзяржава адносілася да гэтага адмоўна. Таму праблема, якую ўздымала "Наша Нива" і ў наступныя гады, не страчвала актуальнасці, але не магла быць вырашана ні знізу з-за адсутнасці магчымасцей, ні зверху - з-за адсутнасці жадання і нават супрацьдзеяння.

41 Wasil Wasilok, Piawun-hawarun, "Nasza Niwa", 25.05.1907, № 20, с. 1.

42 У. Ляхоўскі, Школьная аgукацыя ў Беларусі паgчас нямецкай акупацыі, с. 31. 


\section{Бібліяграфія}

Булгакаў В., Гісторыя беларускага нацыяналізму, Vilnius 2006 [Bulgakaǔ V., Gìstoryâ belaruskaga nacyânalizmu, Vilnius 2006].

Войцех, Зямельная справа у Беларуси (Праgаужэнне), “Наша Нива”, 22.12.1906, № 7, с. 2 [Vojceh, Zâmel'naâ sprava u Belarusi (Pradaŭžènne), "Naša Niva”, 22.12.1906, № 7, s. 2]. Дзядзька Карусь, Беларуская нароgная школа. 2. Беларуская мова у казенной школи, “Наша Нива”, 22.12.1906, № 7, с. 4 [Dzâdz'ka Karus', Belaruskaâ narodnaâ škola. 2. Belaruskaâ mova u kazennoj školi, "Naša Niva”, 22.12.1906, № 7, s. 4].

Документы и материалы по истории Белоруссии (1900-1917 г2.), т. 3, ред. В.Н. Перцев, И.С. Кравченко, Е.П. Лукьянов, А.И. Воронова, Минск 1953 [Dokumenty i materialy po istorii Belorussii (1900-1917 gg.), t. 3, red. V.N. Percev, I.S. Kravčenko, E.P. Luk'ânov, A.I. Voronova, Minsk 1953].

Долбилов М., Русский край, чужая вера. Этноконфессиональная политика империи в Литве и Белоруссии при Алексанgре II, Москва 2010 [Dolbilov M., Russkij kraj, Čužaâ vera. Ėtnokonfessional'naâ politika imperii v Litve i Belorussii pri Aleksandre II, Moskva 2010].

Корбут В., Беларускае пытанне на старонках першых беларускіх газет "Наша Доля" ("Nasza Dola”) i "Наша Нива" ("Nasza Niwa”) (1906 г.) [Korbut V., Belaruskae pytanne na staronkah peršyh belaruskih gazet "Naša Dolâ" ("Nasza Dola”) i "Naša Niva" ("Nasza Niwa") (1906 g.)], "Acta Polono-Ruthenica" 2020, t. 25, z. 3, s. 177-189.

Ляхоўскі У., Ag гоманаўцаў gа гайсакоў. чыннасць беларускіх малаgзёвых арганізацый у 2-й палове XIX - 1-й палове XX ст. (ga 1939 г.) [Lâhoǔskì U., Ad gomanaǔcaǔ da gajsakoǔ. Čynnasc' belaruskih maladzëvyh arganizacyj u 2-j palove XIX - 1-j palove XX st. (da 1939 g.)], Vilnius-Białystok 2012.

Ляхоўскі У., Школьная аgукацыя ў Беларусі паgчас нямецкай акупацыі (1915-1918 г2.) [Lâhoǔskì U., Škol'naâ adukacyâ ǔ Belarusi padčas nâmeckaj akupacyì (1915-1918 gg.)], Vilnius-Białystok 2010.

"Наша Нива", 22.12.1906, № 7, с. 7 [“Naša Niva”, 22.12.1906, № 7, s. 7].

Унучак А. У., «Наша ніва» і беларускі нацыянальны рух (1906-1915 ге.), Мінск 2008 [Unučak A. U., "Naša nìva" ì belaruskì nacyânal'ny ruh (1906-1915 gg.), Minsk 2008].

Ab pierasielenniu, "Nasza Niwa", 12/25.10.1907, № 31, s. 2.

Adzinoki, s. Mikałaeūszczyna Minskaj hub., "Nasza Niwa”, 14 (2).09.1907, № 29, s. 6.

Adzinoki, Z m. Biełaruczy Minskoj h. i u., "Nasza Niwa", 17/30.08.1907, № 27, s. 7.

Baūtruk, h. Sokołka Hrodziensk. hub., "Nasza Niwa”, 12/25.10.1907, № 31, s. 6.

Biełyj Janka, Biełaruskaja Narodnaja szkoła. Pisulka da Redakcji, "Nasza Niwa”, 2/15.12.1906,

№ 4, s. 5-6.

Bierebiendzia, Słonimski pawiet, "Nasza Niwa", 20.07.1907, № 25, s. 7.

Filimon M., List da redakcii, "Nasza Niwa”, 30.03/12.04.1907, № 13, s. 8.

H., [U Wilejskim pawieci...], "Nasza Niwa”, 17/30.08.1907, № 27, s. 6.

Hroch M., Małe narody Europy. Perspektywa historyczna, Wrocław-Warszawa-Kraków 2003. 
Jak adkrywać biblioteki u miasteczkach i wioskach, "Nasza Niwa”, 20.07.1907, № 25, s. 5. Kołas Jakub, Pieśnia kale kałyski, "Nasza Niwa”, 20.04.1907, № 16, s. 1.

Krapiůka Maciej, Jak nam uczycca, "Nasza Niwa”, 10/23.11.1906, № 1, s. 4-5.

Kupała Januk, Na szto? (Paświaszczaju Jakubu Kołasu), "Nasza Niwa”, 28.09.1907, № 30, s. 2. Kupała Januk, Wuczysia!.., "Nasza Niwa”, 17/30.08.1907, № 27, s. 1.

Narodny Wuczyciel, Ab nacjonalizacji szkoły. (Hołas wuczyciela-biełarusa), "Nasza Niwa", 16/29.03.1907, № 11, s. 3-5.

"Nasza Niwa", 17/30.11.1906, № 2, s. 2.

Pacztowaja skrynka, "Nasza Niwa", 17/30.08.1907, № 27, s. 8.

Radzik R., Białorusini między Wschodem a Zachodem, Lublin 2012.

Radzik R., Między zbiorowościq etniczną a wspólnotą narodową. Białorusini na tle przemian narodowych w Europie Środkowo-Wschodniej XIX stulecia, Lublin 2000.

Staliūnas D., Rusinimas. Lietuva ir Baltarusija po 1863 metų, Vilnius 2009.

Szpektar M., M. Duniłowiczy. Wilejskaho pawietu Wil. hub., "Nasza Niwa", 20.07.1907, № 25, s. 6-7.

Szul R., Język. Naród. Państwo. Język jako zjawisko polityczne, Warszawa 2009.

Ukrainskaja mowa u uniwersytetach, "Nasza Niwa", 10/23.11.1907, № 33, s. 3-4.

Wasilok Wasil, Piawun-hawarun, "Nasza Niwa”, 25.05.1907, № 20, s. 1.

Wilnia 13(26) apryla, "Nasza Niwa", 13/26.04.1907, № 15, s. 1.

Wilnia 25 maja, "Nasza Niwa", 25.05.1907, № 20, s. 1.

Z Biełarusi i Litwy. (Ad naszych korespondentoŭ), "Nasza Niwa”, 8/21.06.1907, № 22, s. 6. Zjezd tak-zwanaho "Sojuza Russkaho Naroda", "Nasza Niwa”, 3/16.08.1907, № 26, s. 2. 


\section{Фармаванне беларускага пантэона ў перыяд хрушчоўскай адлігі}

Formation of the Belarusian pantheon in the period of Khrushchev's "Thaw"

The article considers the specifics and mechanism of constructing the Belarusian national pantheon, which, to a large extent, formed the collective identity during Khrushchev's "Thaw". The socio-political context in the Soviet Union that caused the appearance of a pantheon of national heroes is analyzed, and options for their commemoration and presentation are revealed. The construction of the Belarusian pantheon at the time in question was the result of initiatives of the national intelligentsia, undertaken mostly on the eve of various anniversaries. Not all such initiatives met with the support of the Party leadership of the Republic, who used the lion's share of their forces and funds on the memorialization of the events of World War II. The national pantheon formed in Soviet Belarus during Khrushchev's "Thaw" was a bizarre hybrid of national cultural figures and war heroes who embodied Soviet internationalism.

Ke y w o rd s: pantheon, Thaw, national heroes, identity, commemoration, intellectuals, Communist Party and state officials

Kształtowanie panteonu bohaterów białoruskich w okresie odwilży chruszczowowskiej

W artykule omówiono specyfikę i mechanizm budowy białoruskiego panteonu narodowego, który w dużej mierze kształtował tożsamość zbiorową podczas odwilży chruszczowowskiej. Zanalizowany został kontekst społeczno-polityczny, który doprowadził do pojawienia się panteonu bohaterów narodowych w Związku Radzieckim, przedstawiono także pojawiające się wówczas możliwości upamiętniania i prezentowania tych postaci. Budowa białoruskiego panteonu w omawianym okresie była wynikiem inicjatyw inteligencji narodowej, podejmowanych najczęściej w przededniu różnych rocznic. Nie wszystkie tego typu próby spotykały się z poparciem kierownictwa partyjnego republiki, które Iwią część sił i środków przeznaczało na upamiętnianie wydarzeń II wojny światowej. Narodowy panteon utworzony na sowieckiej Białorusi podczas odwilży chruszczowowskiej był dziwaczną hybrydą narodowych postaci kultury i bohaterów wojennych, którzy ucieleśniali sowiecki internacjonalizm.

Słowa kluczowe: panteon, odwilż, bohaterowie narodowi, tożsamość, upamiętnienie, intelektualiści, partia komunistyczna i urzędnicy państwowi 
Кожная нацыянальная культура мае ўласны набор герояў, якія складаюць славу айчыны. Іх вобразы ўвасоблены ў літаратуры і мастацтве, іх біяграфіі вывучаюць у школах і ўніверсітэтах, у выніку чаго фармуецца калектыўная культурная памяць нацыі. На працэс стварэння кожнага нацыянальнага пантэона, у тым ліку беларускага, наклалі адбітак шматлікія ваеннапалітычныя і сацыякультурныя чыннікі, што надавала яму складаны, а часам, парадаксальны характар'. Незавершанасць фармавання беларускага нацыянальнага пантэона (i, адпаведна, недафармаванасць культурнагістарычнай памяці беларускага народа) актуалізуе задачу вывучэння розных этапаў гэтага працэсу, кожны з якіх мае свае асаблівасці. Адным з важных, але маладаследаваных этапаў стварэння беларускага нацыянальнага пантэона з'яўляюцца гады, якія ўвайшлі ў гісторыю пад назвай хрушчоўская адліга.

Звычайна, штуршком для ўшанавання, мемарыялізацыі таго ці іншага героя беларускай гісторыі уу разглядаемы час з’яўлялася юбілейная дата. Галоўная постаць беларускага пантэона - Францішак Скарына не з'явіўся выключэннем з гэтага правіла. Пра постаць Ф. Скарыны, выкрэсленую з публічнага дыскурсу падчас "культурнай рэвалюцыі" 1930-х гадоў, партыйныя ідэолагі ўзгадалі як пра "першага рускага першадрукара" ў часы змагання з “бязроднымі касмапалітымі” і “нізкапаклонствам перад Захадам”. Падобным чынам нацыянальная прыналежнасць "першага ў Расіі доктара медыцыны” разумелася полацкімі гарадскімі ууладамі, якія ініцыявалі яго камемарацыю напярэдадні 440-годдзя выхаду Псалтыра. У прыватнасці, у лістападзе 1956 года выканаўчы камітэт Полакага гарадскога савета

1 Белорусский пантеон. Июнь-2012, “Новости НИСЭпИ” 2012, № 2 (64), с. 26-27; Г. Коршунов, Проблема исторической памяти на цифровом изломе эпох, [у:] Историческая память о Беларуси как фактор консолияации общества. Мат-лы межg. науч.-практ. конф., г. Минск, 26-27 сент. 2019 г., ред. кол.: Г. Коршунов (гл. ред.) и др., Минск 2019, с. 5-7; К. Лашкевіч, Захар Шыбека: Беларусы спраўgзіліся як нацыя, бо ў нас з'явіліся нацыянальныя героі, “TUT.BY", 21.07.2011, https://news. tut.by/society/242619.html [дата звароту: 11.01.2021]; Национальный пантеон Беларуси. Онлайн-конференция, "Naviny.by", 24.02.2012, https://naviny.media/rubrics/ society/2012/02/24/ic_articles_116_176955 [дата звароту: 11.01.2021]; Пантэон герояў. Чаму сяроg беларускіх герояу так мала жанчын?, "Народная воля" 2013, № 18, с. 6; В. Ракіцкі, Беларускі пантэон, "Радыё Свабода", 1.11.2001, https://www.svaboda. org/a/24866544.html [дата звароту: 11.01.2021]; Н. Стужынская, У грамаgства ёсць попыт на герояў, "Народная воля" 2012, № 115-116, с. 3; eadem, Нацыянальныя сімвалы патрабуюць бляску, "Народная воля" 2012, № 131-132, с. 3.

2 М. Садкович, Георгий Скорина. Исторический роман, Минск 1951. 
перайменаваў Пралетарскую вуліцу ў вуліцу Георгія Скарыны, хадайнічаў аб наданні яго імя Полацкаму педагагічнаму інстытуту, а таксама аб стварэнні помніка на радзіме першадрукара³.

Паступова, дзякуючы намаганням беларускай творчай і навуковай інтэлігенцыі постаць Скарыны набывала беларускія рысы. Да часу прыняцця пастановы Полацкага гарсавета, скульптар Аляксей Глебаў выканаў драўляны паўнароставы скульптурны партрэт Ф. Скарыны (1955), гісторык Валянціна Чапко - абараніла прысвечаную яму дысертацыю 4 і выдала адпаведны нарыс 5 . У 1957 годзе Пётр Сергіевіч стварыў знакамітую працу Скарына ў gрукарні, у наступным годзе свае бачанне першадрукара прапанаваў мастак Лазар Ран, з друку выйшла прысвечанае яму даследаванне Мікалая Алексютовіча ${ }^{6}$, а таксама драматычная паэма Міхася Клімковіча7.

Працэсы вяртання Беларусі яе нацыянальнага героя, замацавання яго (а разам з ім - усіх беларусаў) у еуррапейскай культурнай прасторы значна паскорыла святкаванне 450-годдзя беларускага кнігадрукавання. Напачатку юбілейнага года Беларускае тэлеграфнае агенцтва ў кароткім паведамленні падкрэсліла нацыянальную прыналежнасць першадрукара тройчы: "450 гадоў таму вядомы беларускі асветнік, доктар Георгій (Францішак) Скарына заснаваў у Празе беларускую друкарню і выпусціў у ёй першую беларускую

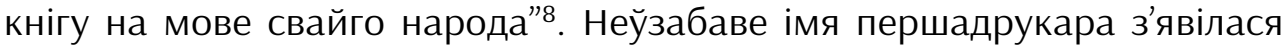
ў назвах полацкай друкарні і вуліцы ў гарадскім пасёлку шаркаўшчына9

15 жніўня 1967 года ў Мінску адбыліся знакавыя імпрэзы: навуковая сесія ў Акадэміі навук БССР10, урачыстае пасяджэнне ў Белдзяржфілармоніі, навуковая канферэнцыя ў Бду1․ На Беларускім радыё у той дзень прайшоў Дзень кнігі, на Цэнтральнай плошчы сталіцы - кніжны кірмаш ${ }^{12} .17$ жніўня

3 Увекавечанне памяці Г. Скарыны, “Літаратура і мастацтва" 1956, № 45, с. 4.

4 В. Чепко, Общественная и культурная деятельность Георгия Скорины. Автореф. gисс. на соиск. уч. степ. канд. истор. наук, Минск 1953.

5 В. Чапко, Беларускі першаgрукар Георгій Скарына, Мінск 1956.

6 М. Алексютовіч, Скарына, яго gзейнасць і светапогляg, Мінск 1958.

7 М. Климкович, Георгий Скорина. Драматическая поэма, Ленинград 1958.

8 "Знамя юности" 1967, № 3, с. 3.

9 Імем беларускага першаgрукара, “Літаратура і мастацтва” 1967, № 45, с. 3.

10450 гоg беларускага кнігаgрукавання. 1517-1967. Зборнік артыкулаў, Мінск 1968.

11 Тэзісы gаклаgаў навуковай канферэнцыі, прысвечанай 450-гоgзю беларускага кнігаярукавання (25 лістапаgа 1967 г.), рэд. М. Ларчанка, Мінск 1967.

12 Узрасло буйным коласам зерне скарынава, “Літаратура і мастацтва" 1967, № 65, C. 1 . 
свята перамясцілася ў Полацк ${ }^{13}$. Неўзабаве быў заснаваны дыплом імя Ф. Скарыны, які штогадова ўручаўся пераможцам Рэспубліканскага конкурсу мастацтва кнігі. Працягнулася камемарацыя Ф. Скарыны мастацкімі сродкамі: выйшлі юбілейны медаль і паштоўка. З’яўленню помніка ў Полацку перашкодзіла заўчасная смерць А. Глебава - бронзавую скульптуру, выкананую вучнямі майстра паводле яго мадэлі, усталявалі толькі уу 1974 годзе. Замацаванню вобраза нацыянальнага героя ў масавай свядомасці насельніцтва БССР паспрыяла кіно. У 1969 годзе ў дадатак да дакументальнага фільма, прысвечанага першадрукару, з'явілася адна з лепшых стужак кінастудыі "Беларусьфільм" - Я, Франциск Скорина..., якая стала крыху запозненым завяршэннем юбілею.

Вывучэнне і рэінтэрпрэтацыя постаці Ф. Скарыны справакавала спробы карэкціроўкі афіцыйнага гістарычнага наратыву, прынамсі эпохі Рэнесансу. Гэтаму паспрыяла таксама выданне у 1960 годзе Інстытутам філасофіі і права АН БССР першага статута Вялікага Княства Літоўскага ${ }^{14}$. Падчас падрыхтоўкі выдання статута, якая распачалася у 1957 годзе, Язэп Юхо выступіў у друку з артыкулам, дзе падводзіў чытачоў да думкі аб яго беларускім паходжанні. Акрамя таго вучоны згадваў канцлера вялікага літоўскага Льва Сапегу, які падчас падрыхтоўкі трэцяга статута карыстаўся выданнямі Ф. Скарыны ${ }^{15}$. 3 артыкула публіцыста А. Дземчанкі можна было даведацца, што змешчаная на тытульным аркушы статута ВКЛ выява "Пагоні" маецца таксама на гістарычных гербах Слуцка, Лепеля, Магілёва, Полацка і Рэчыцы ${ }^{16}$. Нарэшце, у дыскусіі па кнізе Аляксандра Коршунава Апанас Філіповіч: Жыццё і творчасць М. Алексютовіч выказаў думку пра патрэбу пераасэнсавання беларускай старажытнай дзяржаўнасці17.

9 студзеня 1956 года намеснік старшыні Гродзенскага абласнога аддзялення Саюза пісьменнікаў БССР Аляксей Карпюк звярнуўся да сакратара ЦК КПБ па ідэалогіi Цімафея Гарбунова з прапановай “[...] ушанаваць памяць выдатных дзеячаў беларускай культуры Кастуся Каліноусскага, Валерыя Урублеўскага, Алаізы Пашкевіч Цёткі, Багдановіча, Карскага і іншых". Пісьменнік падрабязна выклаў уласнае бачанне таго,

13 На раgзіме першаgрукара, “Літаратура і мастацтва" 1967, № 66, с. 1.

14 Статут Великого княжества Литовского 1529 гоgа, ред. К. Яблонскис, Минск 1960.

15 І. Юхо, Хто склаgаў літоўскі статут?, "Беларусь" 1958, № 3, с. 31.

16 А. Демченко, Старые гербы гороgов Белоруссии, "Знамя юности" 1957, № 229, C. 4 .

17 М. Алексютовіч, А gзе ж ісціна аб’ектыўная?, “Полымя" 1966, № 5, с. 179-185. 
каму трэба ўсталяваць помнікі і мемарыяльныя шыльды, а каго ўшанаваць наданнем іх імёнаў вуліцам, навучальным і культурным установам. Часткова падтрыманая вышэйшым партыйным кіраўніцтвам рэспублікі, 31 студзеня 1957 года гэтая прапанова, у рэдукаваным выглядзе, увасобілася ў пастанове Гродзенскага аблвыканкама “Аб ушанаванні памяці выдатных дзеячаў беларускай культуры акадэміка Карскага Я. Ф. і беларускай паэткі Пашкевіч (Цёткі) А. С."18.

Адпаведна ёй, імя яўхіма Карскага было нададзена Гродзенскай абласной бібліятэцы ${ }^{19}$ і Лашанскай сярэдняй школе з усталяваннем там мемарыяльнай дошкі20. Імя Алаізы Пашкевіч (Цёткі) атрымалі Гродзенскае культасветвучылішча і сярэдняя школа у г. п. Астрына Васілішкаўскага раёна. Там жа, на радзіме паэткі быў усталяваны паўнароставы бронзавы помнік працы Андрэя Заспіцкага 21. Напрыканцы 1958 года з'явіўся бюст Цёткі ля ўвахода ў Шастакоўскую васьмігодку22.

Камемарацыю Максіма Багдановіча падштурхнула 40-годдзе з дня яго смерці, якое адзначалася паводле ініцыятывы Саюза пісьменнікаў БСср у 1957 годзе. Гродзенскія гарадскія ўлады надалі імя паэта Агароднай вуліцы. у бібліятэках Мінска і іншых гарадоў прайшлі выставы і вечарыны, прысвечаная яго памяці. 3 Яраслаўля ў беларускую сталіцу перадалі бібліятэку і архіў сям'і Багдановічаў. У Місхоры, на тэрыторыі санаторыя "Беларусь" быў усталяваны пагрудны скульптурны партрэт М. Багдановіча працы Заіра Азгура 23 . у 1958 годзе на Мінскай студыі тэлебачання паставілі тэлеспектакль Ля сіняй бухты паводле аднайменнай аповесці Барыса Бур'яна²4. у 1959 годзе, неўзабаве пасля з'яўлення біяграфічнага даследавання Сцяпана Майхровіча ${ }^{25}$, першае, звязанае з нараджэннем паэта "месца памяці" уу выглядзе мемарыяльнай шыльды з'явілася ў Мінску²6,

18 Спаgчына акаgэміка Яўхіма Карскага. Да 150-гоggзя з дня нараgжэння, склад. В. Скалабан, К. Суша, Мінск 2010 [электронны рэсурс].

19 Библиотека имени акаgемика Е. Карского, "Советская Белоруссия" 1957, № 96, C. 4 .

20 Памяти выgающихся люgей, “Советская Белоруссия” 1957, № 49, с. 4.

21 Помнік Цётцы, “Літаратура і мастацтва” 1957, № 73, с. 2.

22 “Літаратура і мастацтва" 1958, № 58, с. 4.

23 Я. Камароўскі, Помнік М. А. Багgановічу, “Літаратура і мастацтва” 1957, № 37, C. 3.

24 Ул. Бойка, “Ля сіняй бухты", “Літаратура і мастацтва" 1958, № 91, с. 4.

25 С. Майхровіч, Максім Багgановіч. Жыццё і творчасць, Мінск 1958.

26 3gесь рояился поэт Максим Богgанович, “Советская Белоруссия” 1959, № 75, с. 4. 
у 1962 годзе другое "месца памяці", звязанае з апошнімі днямі яго жыцця, вызначыла мемарыяльная шыльда на доме па вуліцы Камунараў у Ялце27. Падчас святкавання 70-годдзя з дня нараджэння М. Багдановіча яго імя было нададзена Смалявіцкай раённай бібліятэцы ${ }^{28}$. А у 1966 годзе вобраз паэта ўвасобіў у сваёй дыпломнай працы Сяргей Вакар - аўтар будучага помніка на плошчы Парыжскай камуны ў Мінску ${ }^{29}$.

Найбольшыя складанасці ў ідэалагічнага кіраўніцтва КПБ выклікала прапанова Аляксея Карпюка ўключыць у мемарыяльны ландшафт Беларусі герояў паўстання 1863-1864 гадоў, у прыватнасці Кастуся Каліноўскага. Гэта тлумачылася цяжкасцямі, з якімі ўваходзіла яго постаць у афіцыйны савецкі ідэалагічны дыскурс у 1920-1940-я гады. У лістападзе 1958 года на радзіме яму быў усталяваны пагрудны бюст працы 3. Азгура. Тады ж экспазіцыю Дзяржаўнага мастацкага музея БССР узбагаціла карціна Адольфа Гугеля і Раісы Кудрэвіч Кастусь Каліноўскі. У наступным годзе вобраз правадыра паўстання разам з яго паплечнікам В. Урублеўскім стварыў П. Сергіевічзо. Замацаванню вобраза беларускага рэвалюцыянера-дэмакрата спрыялі распрацоўкі вучоных-гуманітарыяўำ.

У той жа час у Мінску не знайшла падтрымкі ідэя А. Карпюка аб наданні імя Каліноўскага Гродзенскаму педінстытуту, а таксама прынятае ў студзені 1958 года рашэнне гродзенскіх абкама партыі і аблвыканкама аб адкрыцці ў Свіслачы дзяржаўнага музея, прысвечанага правадыру паўстанняз2 (з дапамогай віленскіх і варшаўскіх музеяў быў створаны грамадскі музей у Свіслацкай школе-інтэрнаце) ${ }^{33}$. Цімафей Гарбуноў таксама не падтрымаў праект пастановы Гродзенскага абкама КПБ ад 17 красавіка 1957 года “Аб узвядзенні помніка Валерыю Урублеўскаму ў г. п. Жалудок Гродзенскай вобласці". Нягледзячы на заслугі паплечніка К. Каліноўскага, які таксама

27 Памяці Максіма Багgановіча, “Літаратура і мастацтва” 1962, № 87, с. 1.

28 у бібліятэцы імя Паэта, “Літаратура і мастацтва” 1961, № 97, с. 3.

29 “Літаратура і мастацтва" 1966, № 58, с. 1.

30 Г. Кісялёў, Любімая тэма мастака (з юбілейнай выстаўкі П. Сергіевіча), “Літаратура і мастацтва” 1961, № 38, с. 4.

31 І. Лушчыцкі, Нарысы па гісторыі грамаgска-палітычнай і філасофскай gумкі ў Беларусі ў gругой палавіне ХІХ веку, Мінск 1958, с. 171-255.

32 музей К. Каліноўскага, “Літаратура і мастацтва" 1958, № 7, с. 2.

33 А. Унучак, Ушанаванне памяці Кастуся Каліноусккага на Свіслаччыне (1958-1989 ге.), [у:] Гісторыка-культурная спаgчына Свіслацкага краю (ga 760-гоggзя гораgа Свіслач). 6-я Тышкевіцкія чытанні, Свіслач, 2 верасня 2016 г. Зборнік артыкулаў, рэдкал. А. Смолік (адк. рэд.) і інш., Мінск 2018, с. 58. 
з'яўляўся генералам парыжскай камуны і дзеячам I Інтэрнацыянала, сакратар ЦК па ідэалогіі наклаў рэзалюцыю: “Варта яшчэ раз да гэтага вярнуцца”. У выніку імя В. Урублеўскага было ўшанавана на радзіме толькі памятным знакам-каменем, а таксама назвай вуліцы і школы ${ }^{34}$.

Насцярожанасць у стаўленні беларускіх ідэолагаў да постаці К. Каліноўскага саслабела пасля таго, як у жніўні 1962 года выйшла пастанова ЦК КПСС “Аб мерапрыемствах, звязаных са 100-годдзем польскага паўстання 1863 года"35. У Беларусі, акрамя санкцыянаванага Масквой з мэтай “умацавання братэрскіх адносін з сацыялістычнай Польшчай” юбілею паўстання, святкавалася 125-годдзе з дня нараджэння К. Каліноўскага, якое таксама прыпадала на 1963 год. Атмасферу абодвух святкаванняу стварала набраўшая моц лібералізацыя грамадска-палітычнага жыцця і паслабленне ідэалагічнай цэнзуры.

Напярэдадні правядзення юбілейных мерапрыемстваў выйшлі з друку працы беларускіх гісторыкаў, у якіх К. Каліноўскі быў ахарактарызаваны як выдатны прадстаўнік грамадскай думкі XIX стагоддзя, першы беларускі рэвалюцыянер і кіраўнік сялянскага паўстання ${ }^{36}$. У юбілейным годзе з'явілася кніга Генадзя Кісялёва, у якой была нададзена вялікая ўвага нацыянальнаму пытанню ў паўстанні і поглядам К. Каліноўскага. Фактычна аўтар сцвярджаў, што Каліноўскі аддаў жыццё за вольную Беларусь, якая ў яго час разумелася ў выглядзе Вялікага Княства Літоўскагаз7.

24 студзеня 1963 года адбыўся ўрачысты сход, арганізаваны сумесна Аддзяленнем гуманітарных навук АН БССР, Таварыствам культурных сувязей з замежжам і БДУ. 29-30 чэрвеня таго ж года навуковая сесія, арганізаваная Інстытутам гісторыі АН БССР і Гродзенскім педінстытутам прайшла ў Свіслачы. Вуліцы імя К. Каліноўскага з'явіліся ў Мінску і Свіслачы. Адбыўся шэраг выстаў у музеях і бібліятэках рэспублікі. Беларускі кінарэжысёр Пётр Шамшур стварыў дакументальную стужку, прысвечаную юбіляру. Уладзімір Караткевіч напісаў раман Каласы паg сярпом тваім і п'есу

34 Нацыянальны архіў Рэспублікі Беларусь [далей: НАРБ], ф. 4П: Центральный комитет Коммунистической партии Белоруссии, воп. 62, спр. 486: Постановление Гродненского обкома КПБ от 17 апреля 1957 г. "О возведении памятника Валерию Врублевскому в г. п. Желудок Гродненской области”, арк. 300-301.

35 НАРБ, ф. 4П, воп. 62, спр. 602: Письмо ЦК КПБ “О мероприятиях, связанных со 100-летием польского восстания 1863 года”, арк. 140.

36 А. Смірноў, Кастусь Каліноўскі ў паўстанні 1863 гоgа, Мінск 1959.

37 Г. Кісялёў, Сейбіты вечнага. Артыкулы пра беларускіх пісьменнікаў і gзеячаў рэвалюцыйнага руху 1863 гоgа, Мінск 1963, с. 5-121. 
Кастусь Каліноўскі: смерць і няўміручасць (абодва творы былі спынены цэнзурай). Такім чынам, з пэўнымі агаворкамі, на дзяржаўным узроўні было прызнана, што паўстанне 1863-1864 гадоў мела пазітыўнае значэнне для беларускай гісторыі, а асоба Кастуся Каліноўскага "займае высокае месца сярод славутых беларусаў усіх часоў’38.

Змягчэнне ідэалагічнага дыктату пасля смерці Сталіна дазволіла прадстаўнікам беларускай інтэлігенцыі ўзняць пытанне аб камемарацыі Францішка Багушэвіча, які да таго часу ўжо набыў статус класіка беларускай літаратуры. У 1953 годзе імя Ф. Багушэвіча было нададзена Ашмянскаму краязнаўчаму музею, у 1957 годзе - бібліятэцы ў Кушлянах і калгасу у Жупранах, у 1962 г. - Жупранскай сярэдняй школе ${ }^{39}$. У 1958 годзе вобраз Мацея Бурачка уу бронзавым бюсце, усталяваным у Жупранах, увасобіў 3 . Азгур ${ }^{40}$. Мемарыяльная дошка і куток у музеі былі прысвечаны заснавальніку новай беларускай літаратуры ў Нежынскім педінстытуце ${ }^{41}$. Тым не менш, прадстаўнікі беларускай інтэлігенцыі настойвалі на неабходнасці мемарыялізацыі Ф. Багушэвіча ў тапанімічнай прасторы беларускай сталіцы ${ }^{42}$.

150-годдзе другога класіка беларускай новай літаратуры Вінцэнта ДунінаМарцінкевіча ў 1957 годзе грамадскасць адзначыла толькі сходамі, лекцыямі, радыёперадачамі, вучэбна-педагагічнае выдавецтва выдала яго партрэт ${ }^{43}$.

У гады хрушчоўскай адлігі працягнулася камемарацыя Янкі Купалы і Якуба Коласа, якія да таго часу зрабіліся сімваламі "мудрай сталінскай нацыянальнай палітыкі", доказам "росквіту савецкіх нацый”. У другой палове 1950-х - першай палове 1960-х гадоў, дзякуючы шматлікім літаратуразнаўчым працам, а таксама экспазіцыям, створаным у мемарыяльных музеях, асобы і творчасць абодвух класікаў набылі новае, антрапалагічнае вымярэнне. Пачаўся асцярожны пошук адказаў на нязручныя пытанні, накшталт дарэвалюцыйнай грамадскай дзейнасці Купалы і Коласа.

38 А. Унучак, 1963 гоg: як у БССР аgзначалася 100-гоggзе паўстання 1863-1864 г2. і 125-гоggзе з gня нараgжэння Кастуся Каліноўскага, "Беларускі гістарычны часопіс" 2013, № 5, с. 14.

39 А. Лойка, Жыццё, вартае паэм, “Літаратура і мастацтва” 1965, № 24, с. 3.

40 Помнік Францішку Багушэвічу, “Літаратура і мастацтва” 1958, № 96, с. 1.

41 М. Кушнірэнка, Памяці Ф. Багушэвіча, “Літаратура і мастацтва" 1965, № 34, с. 3.

42 А. Іванчанка, І. Сарока, Школа ў якой працаваў Ф. Багушэвіч, “Літаратура і мастацтва" 1960, № 42, с. 3.

43 Да 150-гоggзя з gня нараgжэння В. Дуніна-Марцінкевіча, "Літаратура і мастацтва" 1957, № 93, с. 1. 
У 1957 годзе, калі адзначалася 75-годдзе я. Купалы, з'явіўся яго бюст у Радашковічах - горадзе, дзе хрысцілі будучага паэта. На адкрыцці помніка, акрамя ўдавы і сястры песняра, прысутнічаў міністр культуры БССР Рыгор Кісялёў ${ }^{44}$. У тым жа 1957 годзе была заснавана літаратурная прэмія імя Я. Купалы ${ }^{45}$. Ва уурачыстых абставінах праз два гады была адчынена мемарыяльная шыльда на бровары ў яхімаўшчыне, дзе уу 1906-1907 гг. працаваў я. Купала46. 17 мая 1960 года сакратар ЦК КПБ Пётр Машэраў адкрыў новы будынак Дзяржаўнага літаратурнага музея Янкі Купалы ў Мінску47. У тым жа годзе прагучала грамадская ініцыятыва па адкрыцці філіяла музея ў Ляўках ${ }^{48}$. Шэраг важных захадаў па мемарыялізацыі песняра былі здзейснены ў год святкавання яго 80-годдзя: быў закладзены камень на месцы будучага помніка ў Мінску, перавезены з Масквы і пахаваны на Вайсковых могілках парэшткі, адкрыты турыстычны маршрут на радзіму ў Вязынку, зняты дакументальны фільм і напісана кантата, выдадзена паштовая марка, а таксама выраблена разнастайная сувенірная прадукцыя з выявамі юбіляра 49 .

На юбілейнай марцы 1962 года Купала быў паказаны разам з Я. Коласам, юбілей якога ў тым жа годзе быў адзначаны больш сціпла - ён атрымаў толькі школьны музей у вёсцы Пінкавічы Пінскага раёна, дзе уу 19041906 настаўнічаў пясняр ${ }^{50}$. Да таго часу, акрамя Камароўскай плошчы і Паліграфічнага камбіната ў Мінску, перайменаваных у гонар я. Коласа адразу пасля смерці, у 1957 годзе памяць аб ім ушанавалі стварэннем літаратурнай прэміі, адкрыццём мемарыяльнага музея ў яго мінскай сядзібе, а таксама закладкай каменя на месцы будучага помніка51.

Камемарацыя іншых стваральнікаў беларускай літаратуры XX стагоддзя, якая ад пачатку зрабілася не толькі эстэтычнай, але таксама сацыяльнай з'явай, рухавіком фармавання беларускай нацыі мела сціплы характар. У 1956 годзе ў сувязі з 70-годдзем Змітрака Бядулі, выканкам Мінскага гарадаскога савета надаў яго імя вуліцы Галантарэйнай⒉ У 1960 годзе

44 Открытие памятника Янке Купале, “Советская Белоруссия" 1957, № 159, с. 4.

45 Прэміі імя Я. Купалы і Я. Коласа, “Літаратура і мастацтва” 1957, №28, с. 4.

46 Открытие мемориальной доски, “Советская Белоруссия" 1959, № 167, с. 3.

47 Открытие музея Янки Купалы, “Знамя юности” 1960, № 99, с. 4.

48 І. Маісееў, Памятныя мясціны трэба берагчы, "Літаратура і мастацтва" 1960, № 95. c. 3.

49 Да юбілею Янкі Купалы, “Літаратура і мастацтва” 1962, № 39, с. 2.

50 А. Слесарэнка, Трэці раз у Пінкавічах, “Літаратура і мастацтва” 1963, № 88, с. 2.

51 Заклаgка помніка Я. Коласу, “Літаратура і мастацтва" 1957, № 92, с. 1.

52 Увековечение памяти Змитрока Бяgули, “Советская Белоруссия" 1956, № 282, с. 3. 
Уздзенскай раённай бібліятэцы надалі імя Паўлюка Труса ${ }^{53}$. у шэрагу выпадкаў працэс увядзення новых персанажаў у нацыянальны пантэон спыніусся на этапе стварэння навуковых і публіцыстычных твораў, якія не сталі рэсурсам для камемаратыўных практык ${ }^{54}$.

У гады хрушчоўскай адлігі пачалося ўшанаванне дзеячаў, якія належылі да дзвюх - польскай і беларускай культурных традыцый. Гэта рабілася у кантэксце хрушчоўскіх саступак Польшчы, яго імкнення зрабіць так, каб палякі як найхутчэй забылі пра 1939 год. Ні месца нараджэння, ні змест творчасці гэтых асоб ніяк не маглі паўплываць на афіцыйнае вызначэнне іх этнічнасці як выключна польскай. Да 100-годдзя з дня смерці «вялікага польскага паэта» ў лістападзе 1955 года былі адноўлены Дом-музей Адама Міцкевіча ў Наваградку і помнік-абеліск на яго радзіме у Завоссі55. Праз тры гады на доме Элізы Ажэшкі ў Гродне з'явілася шыльда, якая ўшаноўвала "выдатную польскую дэмакратычную пісьменніцу"56. у 1966 годзе на месцы фальварка Убель, дзе нарадзіўся "вялікі польскі кампазітар" Станіслаў Манюшка з'явілася мемарыяльная стэла ${ }^{57}$. Падобным чынам мемарыялізваны у адмысловым музеі у Івянцы (1957), а таксама ў помніках у Івянцы (1953), Мінску (1954) і на шашы Брэст-Масква (1966) “знакаміты савецкі рэвалюцыянер польскага паходжання" Фелікс Дзяржынскі у афіцыйным дыскурсе быў цалкам пазбаўлены беларускай этнічнасці58.

Такім чынам, у гады хрушчоўскай адлігі, нягледзячы на абвешчаны кіраўніком краіны курс на "збліжэнне савецкіх нацыянальнасцей", ва ўмовах грамадска-палітычнай лібералізацыі пачаўся працэс рэгенерацыі нацыянальнай культуры. Калі не ў грамадстве ў цэлым, дык у інтэлігенцкіх колах паўстаў нацыянальны дыскурс, які ў тым ці іншым выглядзе прарываўся ў публічную прастору. Працэс мемарыялізацыі выдатных беларускіх дзеячаў у 1953-1968 гадах меў асцярожны, выбарачны, пераважна

53 Имени Павлюка Труса, “Советская Белоруссия" 1960, № 35, с. 3.

54 С. Майхровіч, Сымон Буgны, “Полымя" 1967, № 2, с. 225-241; М. Прашковіч, Слова пра Афанасія Філіповіча, “Полымя" 1965, № 12, с. 174-177; Е. Прокошина, Мелетий Смотрицкий, Минск 1966.

55 Памятник Agaмy Мицкевичу, “Сталинская молодежь” 1955, № 217, с. 3.

56 Мемориальная gоска в честь Элизы Ожешко, “Советская Белоруссия" 1958, № 162 , С. 2.

57 НАРБ, Ф. 4П, воп. 116, спр. 1: Письмо Министра культуры БССР М.А. Минковича в ЦК КПБ от 13 ноября 1965 г., арк. 91.

58 Музей Ф.Э. Дзержинского: (Очерк-путевоgитель), Минск 1977; Помнік Ф.Э. Дзержынскаму, “Літаратура і мастацтва" 1954, № 5, с. 2. 
літаратурацэнтрычны характар. З’яўленню той, ці іншай гістарычнай постаці ў публічнай прасторы звычайна папярэднічала стварэнне наратыву, з якога ідэолагамі прыбіраліся ўсе непажаданыя факты. Значная частка падзей беларускай гісторыі і нацыянальных дзеячаў зусім знікла альбо дэвальвавалася срозь прызму класавага супрацьстаяння.

Стварэнне ў разглядаемы час нацыянальнага пантэона адбывалася на фоне інтэнсіўнай мемарыялізацыі на тэрыторыі Беларусі падзей Другой сусветнай вайны. Так, у 1954 годзе ў беларускай сталіцы з'явілася новая гарадская дамінанта - помнік-абеліск воінам Савецкай Арміі і партызанам, якія заінулі ў баях за Радзіму на Круглай плошчы. Меншыя па памерах помнікі ахвярам і героям вайны ў сярэдзіне 1950-х гадоў паўсталі ва ўсіх абласных і большасці раённых цэнтраў рэспублікі. Падобны прыярытэтны накірунак камемарацыйнай палітыкі засведчыла прынятая 30 снежня 1958 года пастанова ЦК КПБ “Аб захаванні памятных месц баёў Савецкай Арміі з нямецка-фашысцкімі захопнікамі"59. У рэчышчы яе рэалізацыі да ўжо трывала замацаванага ў грамадскай свядомасці Канстанціна Заслонава дадаўся новы герой беларускага пантэона - піянер Марат Казей, помнік якому з'явіўся ў Мінску ў 1959 годзе ${ }^{60}$.

У тым жа годзе працэс мемарыялізацыі герояў і ахвяр Другой сусветнай вайны набыў цэнтралізаваны, цалкам кантраляваны ідэалагічным кіраўніцтвам харктар. 26 жніўня 1959 года пастановай “Аб навядзенні парадку ў справе ўзвядзення помнікаў” ЦК КПБ манапалізаваў права на рашэнне аб мемарыялізацыя асоб і падзей вайны. Той жа пастановай былі вызначаны 160 месцаў, дзе трэба было стварыць 14 помнікаў, 15 абеліскаў, 8 бюстаў і іншае 61 . Яны адлюстроўвалі склаўшыся да таго часу афіцыйны савецкі наратыў аб Вялікай Айчыннай вайне.

Новы штуршок працэсу канструявання савецкай калектыўнай памяці аб вайне мемарыяльнымі сродкамі далі святкаванне 20-годдзя Перамогі, а таксама пастанова ЦК КПБ “Аб далейшай рабоце па ўшанаванні гераічных подзвігаў савецкіх людзей у перыяд Вялікай Айчыннай вайны”, якая выйшла ў студзені 1966 года. У перыяд з 1965 па 1967 год уключна ў БССР было ўзноўлена 67 партызанскіх зямлянак, узведзены 31 курган

59 НАРБ, ф. 4п, воп. 62, спр. 540: Постановление ЦК КПБ от 30 декабря 1958 г. "О сохранении памятных мест боев Советской Армии с немецко-фашистскими захватчиками”, арк. 124.

60 А. Краснапёрка, Помнік юнаму змагару, “Піянер Беларусі" 1959, № 46, с. 1.

61 НАРБ, ф. 4П, воп. 62, спр. 504: Постановление бюро ЦК КПБ от 26 августа 1959 г. "О наведении порядка в деле возведения памятников", арк. 189. 
неўміручасці, закладзена 635 мемарыяльных паркаў, алей і сквераў, узведзена 3500 помнікаў, абеліскаў і мемарыяльных дошак, створана 503 грамадскіх музея, абсталявана 7040 куткоў і пакояў баявой славы, а таксама 1370 ваенных кабінетаў ${ }^{62}$

Адным з найважнейшых ідэалагічных складнікаў савецкага наратыву аб Вялікай Айчыннай вайне быў “савецкі інтэрнацыяналізм", які супрацьстаяў нацыяналізмам у рэспубліках, у тым ліку беларускаму. У дадатак да помніка Максіму Горкаму ў Мінску, паўнароставы помнік Багдану Хмяльніцкаму з'явіўся ў Гомелі (1958), а Аляксандру Сувораву - у Кобрыне (1964). У 1953 годзе аддзел камунальнай гаспадаркі Віцебскага гарсавета ў новым гарадскім скверы ўсталяваў бюст М. Горкага. Акрамя скульптурнай выявы заснавальніка сацрэалізму, розныя часткі Віцебска, у адпаведнасці з планамі гарсавета, павінны былі ўпрыгожыць бюсты Мікалая Гогаля, Уладзіміра Маякоўскага, Льва Талстога і Тараса Шаўчэнкі ${ }^{63}$. Не ўсім гэтым і падобным планам было наканавана здзейсніцца. Адпаведна прынятай 28 верасня 1961 года пастанове ЦК КПСС і Савета Міністраў СССР “Аб ліквідацыі празмернасцей у выдаткаванні дзяржаўных і грамадскіх сродкаў на ўзвядзенне помнікаў”, у БССР было спынена альбо часова прыпынена ўзвядзенне 39 помнікаў. Беларускую сталіцу пазбавілі прымеркаваных да ўзвядзення скульптурных выяў Міхаіла Фрунзэ, Аляксандра Мяснікова і Міхаіла Калініна, Полацк - Уладзіміра Леніна і Францішка Скарыны, Гродна - Валянціна Таўлая, вёску Студзёнку Барысаўскага раёна - помніка на месцы пераправы Напалеона праз Бярэзінуб

Створаны ва ўмовах хрушчоўскай лібералізацыі беларускі савецкі пантэон уяўляу сімбіёз нацыянальнага і імперскага наратываў. Ствараемая прапагандай савецкая ідэнтычнасць у ім накладалася на этнічную прыналежнасць і нават, валодаючы некаторымі этнахарактарыстыкамі, замяняла яе. Кансенсусны характар створанага ў часы хрушчоўскай адлігі беларускага пантэона, які фармаваў гібрыдную масавую свядомасць, мірна праіснаваў да мяжы 1980-1990-х гадоў. Усплёск грамадскай актыўнасці, рост нацыянальнай свядомасці ў беларускім грамадстве, а галоўнае, спробы

62 НАРБ, ф. 4п, воп. 65, спр. 163: Отчет Республиканской комиссии по увековечиванию героических подвигов советских людей в период Великой Отечественной войны, арк. 55.

63 Н. Макаеў, Скульптуры пісьменнікаў, “Літаратура і мастацтва" 1953, № 43. с. 4.

64 НАРБ, ф. 4П, воп. 62. спр. 562: Постановление ЦК КПСС и Совета Министров СССР от 28 сентября 1961 г. "О ликвидации излишеств в расходовании государственных и общественных средств на возведение памятников”, арк. 243-248. 
выкарыстаць мінулае для новага дзяржаўнага будаўніцтва непазбежна парушылі гэты кансенсус. Паўстала супрацьстаянне паміж савецкай імперскай і беларускай нацыянальнай памяцямі.

\section{Бібліяграфія}

450 гоg беларускага кнігаgрукавання. 1517-1967. Зборнік артыкулаў, Мінск 1968 [450 god belaruskaga knígadrukavannâ. 1517-1967. Zbornik artykulaŭ, Mìnsk 1968].

Алексютовіч М., А gзе ж ісціна аб’ектыўная?, “Полымя" 1966, № 5, c. 179-185 [Aleksûtovič M., A dze ž iscina ab’ektyŭnâ̂?, "Polymâ" 1966, № 5, s. 179-185].

Алексютовіч М., Скарына, яго gзейнасць і светапогляg, Мінск 1958 [Aleksûtovič M., Skaryna, âgo dzejnasc' ì svetapoglâd, Mìnsk 1958].

Библиотека имени акаgемика Е. Карского, “Советская Белоруссия” 1957, № 96, с. 4 [Biblioteka imeni akademika E. Karskogo, "Sovetskaâ Belorussiâ" 1957, № 96, s. 4].

Белорусский пантеон. Июнь-2012, “Новости НИСЭПИ” 2012, № 2 (64), с. 26-27 [Belorusskij panteon. lûn'-2012, "Novosti NISÈPI" 2012, № 2 (64), s. 26-27].

Бойка Ул., “Ля сіняй бухты”, “Літаратура і мастацтва” 1958, № 91, с. 4 [Bojka Ul., "Lâ sinâj buhty", "Litaratura ì mastactva” 1958, № 91, s. 4].

Да 150-гoggзя з gня нараgжэння В. Дуніна-Марцінкевіча, "Літаратура і мастацтва" 1957, № 93, c. 1 [Da 150-hoddzâ z dnâ naradžènnâ V. Dunìna-Marcinkeviča, "Lìtaratura ì mastactva" 1957, № 93, s. 1].

Да юбілею Янкі Купалы, “Літаратура і мастацтва" 1962, № 39, с. 2 [Da ûbileû Ănkì Kupaly, "Litaratura ì mastactva" 1962, № 39, s. 2].

Демченко А., Старые гербы гороgов Белоруссии, “Знамя юности” 1957, № 229, с. 4 [Demčenko A., Starye gerby gorodov Belorussii, "Znamâ ûnosti" 1957, № 229, s. 4].

Заклаgка помніка Я. Коласу, "Літаратура і мастацтва” 1957, № 92, с. 1 [Zakladka pomnika Â. Kolasu, "Litaratura ì mastactva" 1957, № 92. s. 1].

3geсь роgился поэт Максим Богgанович, “Советская Белоруссия” 1959, №75, с. 4 [Zdes' rodilsâ poèt Maksim Bogdanovič, "Sovetskaâ Belorussiâ" 1959, № 75, s. 4].

"Знамя юности" 1967, № 3, с. 3 ["Znamâ ûnosti” 1967, № 3, s. 3].

Іванчанка А., Сарока І., Школа ў якой працаваў Ф. Багушэвіч, “Літаратура і мастацтва" 1960, № 42, c. 3 [Ìvančanka A., Saroka Ì., Škola u âkoj pracavaǔ F. Bagušèvič, "Litaratura ì mastactva" 1960, № 42, s. 3].

Імем беларускага першаgрукара, “Літаратура і мастацтва" 1967, № 45, c. 3 [Imem belaruskaga peršadrukara, "Litaratura ì mastactva" 1967, № 45, s. 3].

Имени Павлюка Труса, “Советская Белоруссия" 1960, № 35, с. 3 [Imeni Pavlûka Trusa, "Sovetskaâ Belorussiâ" 1960, № 35, s. 3].

Камароўскі Я., Помнік М. А. Багgановічу, “Літаратура і мастацтва" 1957, №37, с. 3 [Kamaroŭski Â., Pomnik M. A. Bagdanoviču, "Litaratura ì mastactva" 1957, № 37, s. 3]. 
Кісялёў Г., Любімая тэма мастака (з юбілейнай выстаўкі П. Сергіевіча), "Літаратура і мастацтва" 1961, № 38, с. 4 [Kìsâlëŭ G., Lûbìmaâ tèma mastaka (z ûbilejnaj vystaŭkì P. Sergieviča), "Litaratura ì mastactva” 1961, № 38, s. 4].

КісялёўГ., Сейбіты вечнага. Артыкулы пра беларускіх пісьменнікаў і gзеячаў рэвалюцыйнага руху 1863 гоgа, Мінск 1963, с. 5-121 [Kìsâlëŭ G., Sejbity večnaga. Artykuly pra belaruskih pis'mennikaŭ ì dzeâčaŭ rèvalûcyjnaga ruhu 1863 goda, Mìnsk 1963, s. 5-121].

Климкович М., Георгий Скорина. Драматическая поэма, Ленинград 1958 [Klimkovič M., Georgij Skorina. Dramatičeskaâ poèma, Leningrad 1958].

Коршунов Г., Проблема исторической памяти на цифровом изломе эпох, [у:] Историческая память о Беларуси как фактор консолияации общества. Мат-лы межg. науч.-практ. конф., г. Минск, 26-27 сент. 2019 г., ред. кол.: Г. Коршунов (гл. ред.) и др., Минск 2019, с. 5-7 [Koršunov G., Problema istoričeskoj pamâti na cifrovom izlome èpoh, [u:] Istoričeskaâ pamât' o Belarusi kak faktor konsolidacii obŝestva: Mat-ly mežd. nauč.prakt. konf., g. Minsk, 26-27 sent. 2019 g., red. kol.: G. Koršunov (gl. red.) i dr., Minsk 2019, s. 5-7].

Краснапёрка А., Помнік юнаму змагару, “Піянер Беларусі" 1959, № 46, с. 1 [Krasnapërka A., Pomnik ûnamu zmaharu, "Piâner Belarusi”" 1959, № 46, s. 1].

Кушнірэнка М., Памяці Ф. Багушэвіча, “Літаратура і мастацтва” 1965, № 34, с. 3 [Kušnìrenka M., Pamâcì F. Bagušèviča, "Litaratura ì mastactva” 1965, № 34, s. 3].

Лашкевіч К., Захар Шыбека: Беларусы спраўgзіліся як нацыя, бо ў нас з'явіліся нацыянальныя героі, “TUT.BY", 21.07.2011, https://news.tut.by/society/242619.html [дата звароту: 11.01.2021]; [Laškevič K., Zahar Šybeka: Belarusy spraǔdzilisia âk nacyja, bo ŭ nas z'âvilisâ nacyânalnyâ geroì, "TUT.BY", 21.07.2011, https://news.tut.by/society/242619. html [data zvarotu: 11.01.2021].

“Літаратура і мастацтва" 1958, № 58, с. 4 [“Litaratura ì mastactva” 1958, № 58, s. 4 ]. “Літаратура і мастацтва" 1966, № 58, с. 1 ["Litaratura ì mastactva” 1966, № 58, s. 1]. Лойка А., Жыццё, вартае паэм, “Літаратура і мастацтва” 1965, № 24, c. 3 [Lojka A., Žyccë, vartae paèm, "Litaratura ì mastactva" 1965, № 24, s. 3].

Лушчыцкі І., Нарысы па гісторыі грамаgска-палітычнай і філасофскай gумкі ў Беларусі ў gругой палавіне XIX веку, Мінск 1958 [Luščyckì Ì., Narysy pa gistoryì gramadskapalityčnaj ì filasofskaj dumkì ŭ Belarusì ŭ drugoj palavine 19 veku, Mìnsk 1958].

Maiceеў І., Памятныя мясціны трэба берагчы, “Літаратура і мастацтва” 1960, № 95, с. 3 [Maìseeŭ ì., Pamâtnyâ mâsciny treba beragčy, "Litaratura ì mastactva" 1960, № 95, s. 3]. Майхровіч С., Максім Багgановіч. Жыццё і творчасць, Мінск 1958 [Majhrovič S., Maksim Bagdanovič. Žyccë ì tvorčasc', Mìnsk 1958].

Майхровіч С., Сымон Буgны, “Полымя" 1967, № 2, с. 225-241 [Majhrovì̌ S., Symon Budny, "Polymâ" 1967, № 2, s. 225-241].

Макаеў Н., Скульптуры пісьменнікаў, “Літаратура і мастацтва” 1953, № 43, с. 4 [Makaeŭ N., Skul'ptury pis'mennikaŭ, "Litaratura ì mastactva” 1953, № 43, s. 4].

Мемориальная gоска в честь Элизы Ожешко, “Советская Белоруссия” 1958, № 162, с. 2 [Memorial'naâ doska v čest' Ėlizy Ožeško, "Sovetskaâ Belorussiâ" 1958, № 162, s. 2]. 
Музей К. Каліноўскага, “Літаратура і мастацтва” 1958, №7, с. 2 [Muzej K. Kalinoŭskaga, "Litaratura ì mastactva" 1958, № 7, s. 2].

Музей Ф.Э. Дзержинского: (Очерк-путевоgитель), Минск 1977 [Muzej F.È. Dzeržinskogo: (Očerk-putevoditel'), Minsk 1977].

На раgзіме першаgрукара, "Літаратура і мастацтва" 1967, № 66, с. 1 [Na radzìme peršadrukara, "Litaratura ì mastactva" 1967, № 66, s. 1].

Нацыянальны архіў Рэспублікі Беларусь [далее: НАРБ], ф. 4п: Центральный комитет Коммунистической партии Белоруссии, воп. 62, спр. 486: Постановление Гродненского обкома КПБ от 17 апреля 1957 г. "О возведении памятника Валерию Врублевскому в г. п. Желудок Гродненской области”, арк. 300-301 [Nacyânalny arhiŭ Rèspublikì Belarus' [dalee: NARB], f. 4P: Central'nyj komitet Kommunističeskoj partii Belorussii, vop. 62, spr. 486: Postanovlenie grodnenskogo obkoma KPB ot 17 aprelâ 1957 g. "O vozvedenii pamâtnika Valeriû Vrublevskomu w g. p. Želudok Grodnenskoj oblasti", ark. 300-301].

НАРБ, ф. 4П, воп. 62, спр. 504: Постановление бюро ЦК КПБ от 26 августа 1959 г. "О наведении порядка в деле возведения памятников", арк. 189 [NARB, f. 4p, vop. 62, spr. 504: Postanovlenie bûro CK KPB ot 26 avgusta 1959 g. "O navedenii porâdka v dele vozvedeniâ pamâtnikov", ark. 189].

НАРБ, ф. 4П, воп. 62, спр. 540: Постановление ЦК КПБ от 30 декабря 1958 г. "О сохранении памятных мест боев Советской Армии с немецко-фашистскими захватчиками”, арк. 124 [NARB, f. 4p, vop. 62. spr. 540: Postanovlenie CK KPB ot 30 dekabrâ 1958 g. "O sohranenii pamâtnyh mest boev Sovetskoj Armii s nemecko-fašystskimi zahvatčikami”, ark. 124].

НАРБ, ф. 4П, воп. 62. спр. 562: Постановление ЦК КПСС и Совета Министров СССР от 28 сентября 1961 г. "О ликвидации излишеств в расходовании государственных и общественных средств на возведение памятников", арк. 243-248 [NARB, f. 4p, vop. 62. spr. 562: Postanovlenie CK KPSS i Soveta Ministrov SSSR ot 28 sentâbrâ 1961 g. "O likvidacii izlišestv w rashodovanii gosudarstvennyh i obŝestvennyh sredstv na vozvedenie pamâtnikov", ark. 243-248].

НАРБ, ф. 4П, воп. 62, спр. 602: Письмо ЦК КПБ "О мероприятиях, связанных со 100-летием польского восстания 1863 года”, арк. 140 [NARB, f. 4p, vop. 62. spr. 602: Pis'mo CK КРB "O meropriâtiâh, svâzannyh so 100-letiem pol'skogo vosstaniâ 1863 goda", ark. 140].

НАРБ, ф. 4п, воп. 65, спр. 163: Отчет Республиканской комиссии по увековечиванию героических подвигов советских людей в период Великой Отечественной войны, арк. 55 [NARB, f. 4p, vop. 65, spr. 163: Otčet Respublikanskoj komissii po uvekovečivaniû geroičeskih podvigov sovetskih lûdej w period Velikoj Otečestvennoj vojny, ark. 55].

НАРБ, ф. 4П, воп. 116, спр. 1: Письмо Министра культуры БССР М.А. Минковича в ЦК КПБ от 13 ноября 1965 г., арк. 91 [NARB, f. 4p, vop. 116, spr. 1: Pis'mo Ministra kul'tury BSSR M.A. Minkoviča w CK KPB ot 13 noâbrâ 1965 g., ark. 91].

Национальный пантеон Беларуси. Онлайн-конференция [Nacional'nyj panteon Belarusi. Onlajn-konferenciâ], "Naviny.by", 24.02.2012, https://naviny.media/rubrics/ society/2012/02/24/ic_articles_116_176955 [gата звароту [data zvarotu]: 11.01.2021]. 
Открытие мемориальной gоски, “Советская Белоруссия" 1959, № 167, с. 3 [Otkrytie memorial'noj doski, «Sovetskaâ Belorussiâ» 1959, № 167, s. 3].

Открытие музея Янки Купалы, “Знамя юности" 1960, № 99, с. 4 [Otkrytie muzeâ Ânki Kupaly, "Znamâ ûnosti” 1960, № 99, s. 4].

Открытие памятника Янке Купале, “Советская Белоруссия" 1957, № 159, с. 4 [Otkrytie pamâtnika Ânke Kupale, «Sovetskaâ Belorussiâ» 1957, № 159, s. 4].

Памяти выgающихся люgей, “Советская Белоруссия” 1957, № 49, с. 4 [Pamâti vydaûŝihsâ lûdej, "Sovetskaâ Belorussiâ" 1957, № 49, s. 4].

Памятник Agaмy Мицкевичу, “Сталинская молодежь” 1955, № 217, с. 3 [Pamâtnik Adamu Mickeviču, "Stalinskaâ molodež" 1955, № 217, s. 3].

Памяці Максіма Багgановіча, “Літаратура і мастацтва” 1962, № 87, с. 1 [Pamâcì Maksima Bagdanoviča, "Litaratura ì mastactva" 1962, № 87, s. 1].

Пантэон герояў. Чаму сяроg беларускіх герояў так мала жанчын?, "Народная воля" 2013, № 18, с. 6 [Pantèon geroâŭ. Čamu sârod belaruskih geroâŭ tak mala žančyn?, "Narodnaâ volâ" 2013, № 18, s. 6].

Помнік Ф.Э. Дзержынскаму, “Літаратура і мастацтва" 1954, № 5, с. 2 [Pomnik F.Ė. Dzeržynskamu, "Litaratura ì mastactva” 1954, № 5, s. 2].

Помнік Францішку Багушэвічу, “Літаратура і мастацтва” 1958, № 96, с. 1 [Pomnik Francišku Bagušèviču, "Litaratura ì mastactva" 1958, № 96, s. 1].

Помнік Цётцы, “Літаратура і мастацтва" 1957, № 73, с. 2 [Pomník Cëtcy, "Litaratura ì mastactva" 1957, № 73, s. 2].

Прашковіч М., Слова пра Афанасія Філіповіча, “Полымя" 1965, № 12, с. 174-177 [Praškovič M., Slova pra Afanasiâ Filipoviča, "Polymâ" 1965, № 12, s. 174-177].

Прокошина Е., Мелетий Смотрицкий, Минск 1966 [Prokošina E., Meletij Smotrickij, Minsk 1966].

Прэміі імя Я. Купалы і Я. Коласа, “Літаратура і мастацтва" 1957, № 28, с. 4 [Prèmì ìmâ Â. Kupaly i Â. Kolasa, "Litaratura ì mastactva" 1957, № 28, s. 4].

Ракіцкі В., Беларускі пантэон, "Радыё Свабода", [Rakìckì V., Belaruskì pantèon, "Radyë Svaboda"], 1.11.2001, https://www.svaboda.org/a/24866544.html [data zvarotu: 11.01.2021].

Садкович М., Георгий Скорина. Исторический роман, Минск 1951 [Sadkovič M., Georgij Skorina. Istoričeskij roman, Minsk 1951].

Слесарэнка А., Трэці раз у Пінкавічах, “Літаратура і мастацтва” 1963, № 88, с. 2 [Slesarènka A., Trècì raz u Pìnkavičah, "Lìtaratura ì mastactva" 1963, № 88, s. 2].

Смірноў А., Кастусь Каліноўскі ў паўстанні 1863 гоgа, Мінск 1959 [Smìrnoŭ A., Kastus' Kalìnoŭskì ŭ paŭstannì 1863 goda, Mìnsk 1959].

Спаgчына акаgэміка Яўхіма Карскага. Да 150-гоggзя з дня нараgжэння, склад. В. Скалабан, К. Суша, Мінск 2010 [электронны рэсурс] [Spadс̌yna akadèmika Âŭhìma Karskaga. Da 150-goddzâ z dnâ naradžènnâ, sklad. V. Skalaban, K. Suša, Mìnsk 2010 [èlektronny rèsurs]].

Статут Великого княжества Литовского 1529 гоga, ред. К. Яблонскис, Минск 1960 [Statut Velikogo knâžestva Litovskogo 1529 goda, red. K. Âblonskis, Minsk 1960]. 
Стужынская Н., Нацыянальныя сімвалы патрабуюць бляску, "Народная воля" 2012, № 131-132, c. 3 [Stužynskaâ N., Nacyânal'nyâ simvaly patrabuûc' blâsku, «Narodnaâ volâ" 2012, № 131-132, s. 3].

Стужынская Н., У грамаgства ёсць попыт на герояў, "Народная воля" 2012, № 115116, c. 3 [Stužynskaâ N., U gramadstva ësc' popyt na geroâŭ, "Narodnaâ volâ" 2012, № 115-116, s. 3].

Тэзісы gаклаgаў навуковай канферэнцыі, прысвечанай 450-гоggзю беларускага кнігаgрукавання (25 лістапаgа 1967 г.), рэд. М. Ларчанка, Мінск 1967 [Tèzіsy dakladaŭ navukovaj kanferèncyì, prysvečanaj 450-goddzû belaruskaga knigadrukavannâ (25 listapada 1967 g.), rèd. M. Larčanka, Mìnsk 1967].

у бібліятэцы імя Паэта, “Літаратура і мастацтва" 1961, № 97, с. 3 [U bibliâtècy ìmâ Paèta, "Litaratura ì mastactva" 1961, № 97, s. 3].

Увекавечанне памяці Г. Скарыны, “Літаратура і мастацтва" 1956, №45, с. 4 [Uvekavečanne pamâcì G. Skaryny, "Lìtaratura ì mastactva” 1956, № 45, s. 4].

Увековечение памяти Змитрока Бяgули, “Советская Белоруссия" 1956, № 282, с. 3 [Uvekovečenie pamâti Zmitroka Bâduli, "Sovetskaâ Belorussiâ" 1956, № 282, s. 3].

Узрасло буйным коласам зерне скарынава, “Літаратура і мастацтва" 1967, № 65, с. 1 [Uzraslo bujnym kolasam zerne skarynava, "Litaratura ì mastactva" 1967, № 65, s. 1].

Унучак А., Ушанаванне памяці Кастуся Каліноўскага на Свіслаччыне (1958-1989 г2.), [у:] Гісторыка-культурная спаgчына Свіслацкага краю (ga 760-гоggзя гораga Свіслач). 6-я Тышкевіцкія чытанні, Свіслач, 2 верасня 2016 г. Зборнік артыкулаў, рэдкал. А. Смолік (адк. рэд.) і інш., Мінск 2018 [Unučak A., Ušanavanne pamâci Kastusâ Kalinoŭskaga na Svislaččyne (1958-1989 gg.), [u:] Gistoryka-kul'turnaâ spadčyna Svislackaga kraû (da 760-goddzâ gorada Svislač). 6-â Tyškevickiâ čytanni, Svìslač, 2 verasnâ 2016 g. Zbornik artykulaŭ, rèdkal. A. Smolìk (adk. red.) ì ìnš., Mìnsk 2018].

Унучак А., 1963 гоg. Як у БССР аgзначалася 100-гоggзе паўстання 1863-1864 г2. і 125-гоggзе з gня нараgжэння Кастуся Каліноўскага, "Беларускі гістарычны часопіс" 2013, № 5, c. 14 [Unučak A., 1963 god. Âk u BSSR adznačalasâ 100-goddze paŭstannâ 1863-1864 gg. ì 125-goddze z dnâ naradžènnâ Kastusâ Kalinoŭskaga, "Belaruskì gìstaryčny časopis" 2013, № 5, s. 14].

Чапко В., Беларускі першаgрукар Георгій Скарына, Мінск 1956 [Čapko V., Belaruski peršadrukar Georgij Skaryna, Mìnsk 1956].

Чепко В., Общественная и культурная gеятельность Георгия Скорины. Автореф. gисс. на соиск. уч. степ. канg. истор. наук, Минск 1953 [Čepko V., Obŝestvennaâ i kulturnaâ deâtelnost' Georgiâ Skoriny. Avtoref. diss. na soisk. uč. step. kand. istor. nauk, Minsk 1953].

Юхо І., Хто склаgаў літоўскі статут?, “Беларусь” 1958, № 3, с. 31 [Ûho ì., Hto skladaŭ litoŭski statut?, "Belarus"” 1958, № 3, s. 31]. 


\section{Uwarunkowania społeczno-polityczne i kulturowe życia narodowego Białorusinów w Łatgalii podczas okupacji niemieckiej (1941-1944)}

Socio-political and cultural conditions of the national life of Belarusians in Latgale during the German occupation (1941-1944)

Belarusians were one of the largest ethnic groups in Latvia in the interwar period. The main clusters of the Belarusian population were located in the south-eastern part of the country - in Latgale (former Polish Livonia). In the summer of 1941, Latvia was seized by the Wehrmacht and the occupation regime was established. The German occupying authorities, using the principle of "divide et impera", were willing to give the Belarusians a certain degree of cultural and educational autonomy. In 1941 the Belarusian National Committee (since the spring of 1942: the Belarusian Association) was established in Riga and Dyneburg. The organization of Belarusian education under the German occupation was its priority. In the school years 1941/42 and 1942/43 thirty-five primary schools, two high schools and one agricultural secondary school were opened. Moreover, attempts were made to stimulate artistic and publishing activities. The activities of Belarusians aroused antipathy among local Latvians, who were afraid of an increase in the Belarusian national consciousness in Latgale.

Ke y w o rds: World War II, German occupation, Latvia, Latgale, Belarusians

Uwarunkowania społeczno-polityczne i kulturowe życia narodowego Białorusinów w Łatgalii podczas okupacji niemieckiej (1941-1944)

Białorusini stanowili jedną z najliczniejszych grup narodowościowych na Łotwie w okresie międzywojennym. Główne skupiska ludności białoruskiej znajdowały się w południowo-wschodniej części kraju - w Łatgalii (to dawne Inflanty Polskie). Latem 1941 r. Łatgalia została zajęta przez Wehrmacht, w konsekwencji czego ustanowiono reżim okupacyjny. Niemieckie władze okupacyjne, stosując zasadę „dziel i rządź”, były skłonne przyznać Białorusinom pewną autonomię kulturalno-oświatową. W 1941 r. w Dyneburgu zawiązał się Białoruski Komitet Narodowy (od wiosny 1942 r. - Zrzeszenie Białoruskie). Za priorytet w działalności tej organizacji uznano reaktywację szkolnictwa białoruskiego pod okupacją niemiecką. W latach szkolnych 1941/42 i 1942/43 w Łatgalii udało się utworzyć 35 szkół podstawowych, dwa gimnazja i jedną średnią szkołę rolniczą. Ponadto podejmowano próby 
aktywizacji działalności artystycznej i wydawniczej. Aktywność Białorusinów wzbudziła niechęć miejscowych Łotyszy, którzy obawiali się wzrostu białoruskiej świadomości narodowej w Łatgalii. Słowa kluczowe: Il wojna światowa, okupacja niemiecka, Łotwa, Łatgalia, Białorusini

Złożone dzieje Łatgalii (czyli dawnych Inflant Polskich) sprawiły, że region ten z pewnością można uznać za jeden z najbardziej zróżnicowanych narodowościowo, kulturowo i religijnie obszarów w Europie Środkowo-Wschodniej. Po przyłączeniu regionu do Rzeczypospolitej w XVI w. miejscowa szlachta i ziemiaństwo stopniowo uległy polonizacji. Przedstawiciele tych grup wielokrotnie dawali wyraz swemu przywiązaniu do tradycji Rzeczypospolitej, m.in. biorąc udział w powstaniach narodowych. Inaczej sytuacja kształtowała się na wsi łatgalskiej, gdzie trwał proces asymilacji (rutenizacji) miejscowych Bałtów, którzy stopniowo przejmowali język i kulturę Słowian. W rezultacie pod koniec XIX w. na południu Łatgalii niemała część ludności wiejskiej na co dzień posługiwała się „mową prostą”, czyli różnymi gwarami białoruskimi z domieszką polskiego, łotewskiego i rosyjskiego. Zastanawiając się nad przyczynami tej asymila cji, warto pamięć o sięgających średniowiecza ścisłych związkach tych ziem z Księstwem Połockim. Językowej (biało)rutenizacji miejscowej ludności sprzyjał również fakt, iż w XIX w. Łatgalia znalazła się w składzie guberni witebskiej. W drugiej połowie XIX w., po zniesieniu pańszczyzny oraz zbudowaniu kolei Witebsk - Dyneburg, do Łatgalii napłynęło wielu mieszkańców Witebszczyzny i Połocczyzny. Potwierdzenie obecności białoruskojęzycznych obszarów językowych w tej części Łotwy znajdujemy w badaniach zarówno białoruskich, jak i polskich. Języka używanego nie można jednak utożsamiać z narodowością. Bardzo ważnym czynnikiem kształtującym poczucie przynależności do tej czy innej grupy narodowościowej była religia. Większość (2/3) białoruskojęzycznych chłopów łatgalskich stanowili wyznawcy katolicyzmu, co sprawiło, że na przełomie XIX i XX w. świadomość narodowa wielu z nich ewaluowała w stronę polskości. Gustaw Manteuffel w następujący sposób charakteryzował tę ludność:

Rusini znajdują się tylko na pograniczu siebieskiego i dryzieńskiego powiatu, a mianowicie w dobrach Landskrona, Posiń i okolicach. Po większej części są rzymskokatolickiego wyznania; ci tylko, którzy poprzednio byli greko-unitami, w czwartym dziesiątku bieżącego stulecia na prawosławie nawróceni zostali. Rusini katolicy zawdzięczaja swe oświecenie i żarliwość w wierze zakonowi oo. dominikanów?.

\footnotetext{
${ }^{1}$ G. Manteuffel, Inflanty Polskie oraz Listy znad Bałtyku, Kraków 2009, s. 56.
} 
Właśnie pod wpływem duchowieństwa katolickiego i miejscowej szlachty powstały na północnym brzegu Dźwiny obszary zamieszkane przez polską ludność wiejską. Tymczasem prawosławni znajdowali się w kręgu oddziaływania kultury rosyjskiej, choć mieli silne poczucie odrębności od Rosjan. Nie zmienia to faktu, że znaczny odsetek miejscowych chłopów należących do obu wspomnianych wyznań religijnych nie posiadał wykrystalizowanego poczucia świadomości narodowej i miał poważny problem z identyfikacją narodową. Ludność ta nie utożsamiała się trwale z żadną opcją narodowościową. Nie wykazywała większego zainteresowania kwestią swej tożsamości, często podając różną narodowość w zależności od bieżącej sytuacji politycznej. Unikano definiowania swego pochodzenia i podkreślano związek z regionem zamieszkania (często określano się mianem „tutejsi” lub „miejscowi”).

Na początku XX w. ci ludzie stali się obiektem agitacji ze strony ruchów narodowych: łotewskiego, polskiego i białoruskiego. Ponadto istniał ruch promujący łatgalskość jako odrębną narodowość. Nas interesuje jednak wpływ białoruskich haseł narodowych na miejscową ludność. Za pierwszą próbę „ekspansji” ruchu białoruskiego w Łatgalii należy uznać wydarzenia z lat 1905-1907, kiedy w Dyneburgu i innych miejscowościach Łatgalii pojawiły się pierwsze grupki działaczy białoruskich. Nie pozostawiły one jednak trwałego śladu, gdyż szybko zostały zlikwidowane przez carat. Do kolejnych prób „zakorzenienia” białoruskich haseł narodowych doszło w 1917 r. We wrześniu tego roku ludność gminy pustynskiej (w powiecie dyneburskim) podjęła decyzję o organizacji w roku szkolnym 1917/18 szkolnictwa białoruskiego. Natomiast w grudniu 1917 r. w Dryssie powołano Komitet Białoruski (przewodniczącym był Jazep Suszynski), który rozciągał swoją działalność na powiaty dyneburski i lucyński. Komitet ten wydał rezolucję, w której nawoływano rodaków do organizowania się w celu walki o odrodzenie narodu białoruskiego i jego kultury². Historia przyjęła jednak inny obrót, niż zakładali miejscowi działacze białoruscy. Po rozwiązaniu przez bolszewików samorządów kwestia otwarcia szkół białoruskich w Łatgalii zeszła na dalszy plan.

W 1920 r. Łatgalia znalazła się w granicach Republiki Łotewskiej, która uzyskała niepodległość w 1918 r. Znaczny odsetek obywateli młodego państwa łotewskiego stanowili przedstawiciele narodowości innych niż łotewska. Do najliczniejszych mniejszości narodowych zaliczyć należy m.in. Białorusinów. W okresie międzywojennym liczba Białorusinów na Łotwie wahała się w granicach od 75630 (4,74\%) w 1920 r. do 26867 (1,38\%) w 1935 r. W poniższej tabeli zostały ujęte dane statystyczne dotyczące ludności białoruskiej w Republice Łotewskiej podczas kolejnych spisów ludności.

2 Нацыянальны архіў Рэспрублікі Беларусь (НАРБ), ф. 622, воп. 3, спр. 91, л. 14 зв. 
Liczebność Białorusinów w Republice Łotewskiej na podstawie danych z kolejnych spisów ludności ${ }^{3}$

\begin{tabular}{|l|c|c|c|c|}
\hline \multicolumn{1}{|c|}{ Rok spisu } & 1920 & 1925 & 1930 & 1935 \\
\hline $\begin{array}{l}\text { Liczba } \\
\text { Białorusinów }\end{array}$ & $75630(4,74 \%)$ & $38010(2,06 \%)$ & $36029(1,90 \%)$ & $26867(1,38 \%)$ \\
\hline
\end{tabular}

Największe skupiska ludności białoruskiej na Łotwie znajdowały się w południowo-wschodniej części kraju - w Łatgalii (w historycznych Inflantach Polskich). W tym regionie Białorusini stanowili 4,1\% ogółu mieszkańców. W 1930 r. w poszczególnych powiatach liczebność Białorusinów była następująca: dyneburski 13,5 tys. $(6,7 \%)$, lucyński 4,8 tys. (5,3\%), rzeżycki 2,7 tys. (1,8\%), putyłowski 1,3 tys. $(1,2 \%)^{4}$. Większość łotewskich Białorusinów stanowili bezrolni i małorolni chłopi, którzy odznaczali się bardzo wysokim odsetkiem analfabetyzmu. Nieliczna inteligencja białoruska stanowiła element napływowy i rekrutowała się spośród nauczycieli - absolwentów pedagogicznych seminariów rosyjskich oraz grupy polityków Białoruskiej Republiki Ludowej (BRL), którzy osiedlili się na Łotwie. Mimo to za sprawą nielicznej, lecz bardzo aktywnej grupy inteligencji rozwinęło się życie organizacyjne i kulturalno-oświatowe. Za pierwszą i najbardziej liczącą się organizację białoruską na Łotwie należy uznać stowarzyszenie społeczno-kulturalne Baćkaŭszczyna (Ojczyzna) działające w latach 1921-1925. W stosunkowo krótkim czasie powstał szereg stowarzyszeń białoruskich o charakterze społeczno-kulturalnym, oświatowym, sportowym i politycznym. Zaczęto również wydawać własną prasę, działało szkolnictwo. W szczytowym okresie rozwoju białoruskiej akcji szkolnej na Łotwie istniało blisko 50 białoruskich szkół podstawowych i 3 gimnazja ${ }^{5}$.

Tutejszy ruch białoruski rozwijał się w opozycji do mieszkających tu Polaków i Rosjan. Pomiędzy tymi trzema grupami narodowościowymi zachodził konflikt

3 Źródło: J. Albin, Polski ruch narodowy na Łotwie w latach 1919-1940, Wrocław 1994, s. 12.

4 P. Eberhardt, Problematyka narodowościowa Łotwy, „Zeszyty IGiPZ” 1998, nr 54, Warszawa, s. 25.

5 Problem mniejszości białoruskiej na Łotwie był przedmiotem badan historyków łotewskich. Należy tu wymienić pracę K. Jezawitaua, Беларусы ў Латвіi (Rīga 1927) i I. Apine, Baltkrievi Latvijā (Rīga 1995). Na szczególną uwagę zasługuje publikacja Ėriksa Jēkabsonsa, który jako pierwszy podjął się naukowego ujęcia problemu mniejszości białoruskiej na Łotwie w latach międzywojennych. Zob.: Э. Екабсонс, Белорусы в Латвии в 1918-1940 гоgax, [w:] Беларуская gыяспара як пасярэgніца ў gыялогу цывілізацый. Матэрыялы III Міжнароgнага кангрэса беларусістаў, Мінск 2001, s. 76-93. 
interesów. Działacze narodowi musieli rywalizować o „dusze i serca” miejscowych chłopów. Każda ze stron uważała ludność „tutejszą” za swoją, która w wyniku zawiłości historycznych „odłączyła się” od narodu. W tej rywalizacji młodemu ruchowi białoruskiemu sprzyjał fakt, że w pierwszych latach niepodległości Łotwy miejscowy żywioł polski został poważnie osłabiony, ponieważ na skutek reformy rolnej ziemiaństwo polskie utraciło swoją pozycję gospodarczą, a wielu jego przedstawicieli wyjechało do Polski. Szło to w parze z przychylną Białorusinom, zwłaszcza na płaszczyźnie kulturalnej i oświatowej, polityką państwa łotewskiego. U podstaw tej polityki leżała zasada, zgodnie z którą należało osłabiać miejscowy ruch polski, skłonny do separatyzmów. Z punktu widzenia państwa łotewskiego lepiej było popierać mniej zorganizowanych oraz słabych ekonomicznie i politycznie Białorusinów niż aktywnych i w pełni świadomych swych celów i roszczeń Polaków. W związku z tym w interesie władz łotewskich było uznanie miejscowych katolików „mówiących po białorusku, lecz modlących się po polsku" za Białorusinów, a nie Polaków. Polityka popierania Białorusinów dała się zauważyć podczas spisu ludności w 1920 r., kiedy urzędnicy łotewscy byli skłonni zapisywać narodowość białoruską wielu łatgalskim chłopom, którzy w rzeczywistości nie mieli wykrystalizowanego poczucia świadomości narodowej. Tłumaczy to wysoki odsetek ludności białoruskiej w świetle danych ze spisu w 1920 r. ${ }^{6}$ Zamach stanu na Łotwie w 1934 r. miał decydujący wpływ na sytuację łotewskich Białorusinów. Autorytarny reżim Karlisa Ulmanisa wprowadził politykę unifikacji państwa na różnych płaszczyznach. Wówczas przyjęto zasadę wypierania wpływów kulturalnych i politycznych mniejszości narodowych. Zmiana ustawy o szkolnictwie położyła kres autonomii szkolnej mniejszości narodowych, w tym także białoruskiej? . Po inkorporacji w 1940 r. Łotwy do ZSRS obywatele łotewscy narodowości białoruskiej podzielili los swojego państwa. Społeczność białoruską nie ominęły represje sowieckie, aczkolwiek w znacznie mniejszym stopniu niż Łotyszów lub Polaków8.

6 J. Gierowska-Kałłaur, Stosunek państwa łotewskiego do miejscowych Polaków i Białorusinów w początkach niepodległości łotewskiej, „Studia z Dziejów Rosji i Europy Środkowo-Wschodniej" 2011, t. 46, s. 181-216; J. Grzybowski, Stosunki polsko-białoruskie na Łotwie w latach 1920-1940, [w:] Dialog kultur czy zarzewie konfliktów? Problematyka mniejszości narodowych i etnicznych w Europie, red. T. Gajownik, P. Pietnoczek, K. Sidorkiewicz, Olsztyn 2017, s. 33-48.

7 P. Łossowski, Kraje bałtyckie na drodze od demokracji parlamentarnej do dyktatury 19181934, Wrocław 1972, s. 253-254, 261-263.

8 Ė. Jēkabsons, Padomju represijas pret Latvijas poliem, lietuviešiem, un baltkrieviem 1940. 1941. gadā, [w:] Totalitārie režìmi in to represijas Latvijā 1940. - 1956. gada, Rīga 2007, s. 51-70. 
Po wybuchu wojny pomiędzy III Rzeszą a Związkiem Sowieckim latem $1941 \mathrm{r}$. wojska niemieckie zajęły Łotwę ${ }^{9}$. Wkrótce po zajęciu kraju przez Wehrmacht utworzono Okręg Generalny Łotwa (Generalbezirk Lettland), który administracyjnie wchodził w skład Komisariatu Rzeszy Wschód (Reichskommissariat Ostland), z siedzibą władz w Rydze. Komisarzem generalnym Łotwy Hitler mianował Otto-Heinricha Drechslera. Część działaczy łotewskich żywiła nadzieję, że Niemcy przywrócą ich krajowi niepodległość utraconą w 1940 r., czego konsekwencją było podjęcie przez znaczną część społeczeństwa łotewskiego współpracy z okupantem, m.in. w administracji średniego i niższego szczebla. Jednak przywódcy III Rzeszy nie zamierzali tworzyć na Łotwie nawet marionetkowego rządu lub protektoratu (jak w Czechach). Niemieckie władze okupacyjne musiały liczyć się z różnorodnością narodowościową społeczeństwa na podbitych terenach. Stosunek Niemców do poszczególnych grup narodowościowych na terenie Łatgalii był uwarunkowany zarówno względami ideologicznymi i rasowymi, jak również sytuacją militarną i ekonomiczną III Rzeszy. Przywódcy narodowosocjalistycznych Niemiec postrzegali kraje bałtyckie jako obszar, który po wojnie miał zostać przekształcony w „przestrzeń życiową” (Lebensraum) dla narodu germańskiego. Po wygraniu wojny przywódcy III Rzeszy planowali stworzyć na tym obszarze „bastion niemieckości” poprzez niemieckie osadnictwo i marginalizację miejscowej ludności. W myśl tej koncepcji ludność słowiańską (m.in. Polaków, Ukraińców, Białorusinów) czekały wynarodowienie lub wysiedlenie. W praktyce jednak stosunek okupantów do poszczególnych grup narodowościowych był zróżnicowany, co wynikało z bieżących potrzeb ekonomicznych i wojskowo-politycznych III Rzeszy. W celu ułatwienia sobie zarządzania ludnością okupowanych terenów stosowano zasadę „dziel i rządź”. Starano się rozbudzać lokalne separatyzmy, przeciwstawiać i skłócać poszczególne grupy narodowościowe etniczne, wykorzystując lokalne antagonizmy narodowościowe do pacyfikacji miejscowego społeczeństwa. Taka polityka wyraźnie dała się zauważyć na terenie okupowanej Łotwy, która pod względem narodowościowym stanowiła swoistą mozaikę. Poszczególne grupy stały się przedmiotem manipulacji okupantów. Berlińscy planiści uważali, że należy zapobiec „mieszaniu się krwi” pomiędzy rasowo bardziej i mniej wartościowymi elementami. W dekrecie komisarza Rzeszy Wschód z 27 lipca 1942 r. w sprawie polityki narodowościowej w Estonii, na Łotwie i Litwie czytamy m.in.:

9 Э. Екабсонс, Беларусы ў Латвіі ў часы савецкай і нямецка-фашысцкай акупацыі (1940-1945), „Беларускі Гістарычны Агляд” 2006, т. 13, сш. 26, s. 199-233; Ё. Jēkabsons, Białorusini na Łotwie w okresie okupacji hitlerowskiej (1941-1945), „Studia Interkulturowe Europy Środkowo-Wschodniej" 2014, t. 7, s. 13-26. 
nie wolno asymilować Rosjan i Białorusinów, bo: 1) zepsuje się krew narodów, które będą włączone do Rzeszy; 2) trzeba liczyć się z tym, że Białorusini z Nadbałtyki zostanq przesiedleni do Białorusi właściwej [...]. Istnieje niebezpieczeństwo, że poprzez asymilację Rosjan i Białorusinów mało wartościowe elementy rasowe przenikną potem do narodu niemieckiego [...]. Dlatego polityki narodowościowej nie należy przekazywać zarządom krajowym Litwy, Łotwy i Estonii, ale mocno trzymać ją w rękach niemieckich ${ }^{10}$.

Zgodnie z dyrektywą Ministerstwa Rzeszy do spraw Okupowanych Terytoriów Wschodnich należało chronić miejscowych Białorusinów i Rosjan przed asymilacyjnymi działaniami ze strony Łotyszy, które mogły być realizowane za pośrednictwem szkoły, kościoła i urzędów państwowych. W związku z tym przewidziano wprowadzenie autonomii kulturalno-oświatowej dla Białorusinów i Rosjan. Nie oznaczało to jednak żadnych przywilejów politycznych dla tych narodowości. Autonomię kulturalno-oświatową traktowano wyłącznie jako sposób na rozpoznanie i izolowanie rasowo niepożądanych elementów ${ }^{11}$.

W celu realizacji wspomnianych wyżej założeń postanowiono utworzyć organa mające reprezentować interesy ludności białoruskiej i rosyjskiej. Komisarz Rzeszy Wschód Hinrich Lohse uważał, że Białorusini na Łotwie powinni być traktowani w taki sam sposób, jak ich rodacy w Okręgu Generalnym Białoruś. Twierdził też, że należy ich pozyskać do współpracy z Niemcami ${ }^{12}$.

Tymczasem wybuch wojny niemiecko-sowieckiej wzmógł aktywność białoruskich działaczy narodowych na Łotwie. 10 sierpnia 1941 r. w Rydze odbyło się zebranie grupy przedstawicieli inteligencji białoruskiej, podczas którego powołano grupę inicjatywną utworzenia Białoruskiego Komitetu Narodowego na Łotwie $^{13}$. 26 września 1941 r. grupa działaczy białoruskich wystosowała memoriał do komisarza generalnego Łotwy. Dokument ten zawierał krótki zarys sytuacji mniejszości białoruskiej na Łotwie w okresie międzywojennym. Podkreślano represyjny charakter władz państwa łotewskiego wobec Białorusinów (czego przejawami były proces sądowy nad przywódcami ruchu białoruskiego w 1925 r., zamykanie szkół i delegalizacja organizacji kulturalno-oświatowych po 1934 r.). Następnie autorzy zaznaczali, że:

dziś ludność białoruska byłego wolnego państwa łotewskiego wierzy, że dzieci białoruskie pod pieczą niezwyciężonego niemieckiego Wehrmachtu i jego przywódców ponownie

\footnotetext{
10 Archiwum Akt Nowych (AAN), sygn. T-454, 88/001057-58.

${ }^{11}$ Bundesarchiv, Berlin-Lichterfelde Ost (BA), R 6/173, s. 14, 19-20.

12 Э. Екабсонс, Беларусы ў Латвіi, s. 206-207.

13 Беларусы ў Латвіi, „Раніца”, 20.11.1940, s. 3.
} 
będa miały możliwość uczyć się we własnych szkołach białoruskich, nauczyciele białoruscy nie będa prześladowani za działalność narodowa, a chłopi białoruscy będą mogli w nowych warunkach kontynuować swoją działalność rolniczą dla ogólnej korzyści $1^{14}$.

Na końcu zwracano się do komisarza generalnego z następującymi żądaniami: 1) zezwolić na utworzenie „Białoruskiego Komitetu Narodowego Samopomocy”, który reprezentowałby mniejszość białoruską i dbałby o potrzeby kulturalne i materialne Białorusinów; 2) otworzyć białoruską szkołę średnią w Indrze; 3) powołać stanowisko inspektora szkół białoruskich; 4) zezwolić na otwarcie białoruskich kursów nauczycielskich w Rydze lub Dyneburgu; 5) w Łatgalii, w gminach z przewagą ludności białoruskiej, obsadzić Białorusinami stanowiska pisarzy gminnych i dowódców samoobrony ${ }^{15}$. W październiku 1941 r. memoriał o identycznej treści wystosowała do miejscowego gebietskomisarza grupa działaczy białoruskich w Dyneburgu ${ }^{16}$.

Władze okupacyjne wyszły naprzeciwko oczekiwaniom miejscowych działaczy białoruskich. Białoruski Komitet Narodowy (BKN) został zarejestrowany jako oficjalna reprezentacja Białorusinów na Łotwie. Siedziba organizacji mieściła się w Rydze. Wkrótce powstały filie tej organizacji w Łatgalii. W latach 1941-1942 utworzono filie w Dyneburgu, Krasławiu (Kraslava), Posinie (Posiene), Indrze i Zilupe. W marcu 1942 r. zmieniono nazwę organizacji na Zrzeszenie Białoruskie w Okręgu Generalnym Łotwa. Trzon organizacji tworzyli nauczyciele $^{17}$. Do Zrzeszenia Białoruskiego należeli przede wszystkim osoby biorące udział w życiu narodowym w okresie międzywojennym. Nie brakowało również tych, którzy zapisali się do organizacji z pobudek koniunkturalnych, a w rzeczywistości nigdy nie utożsamiali się z białoruskością ${ }^{18}$. Wśród przywódców i najbardziej aktywnych działaczy organizacji należy wymienić Kanstancina (Kastusia) Jezawitaua (prezesa), Andreja Jakubieckiego, Siarhieja Sacharaua, Aliaksandra Machnouskiego, Piotra Miranowicza. Zgodnie ze statutem Zrzeszenie Białoruskie miało za zadanie zrzeszenie Białorusinów mieszkających na terytorium byłego państwa łotewskiego w celu prowadzenia wspólnej pracy na rzecz

14 ВА. R 92/101. Арк. 59-63; Нацыянальны архіў Рэспублікі Беларусь (НАРБ), ф. 458, воп. 1, спр. 59, л. 1-5.

15 BA, R 92/101, S. 59-63.

16 Беларускае жыцьцё ў Лацьвіі, „Раніца”, 5.02.1942, s. 4.

17 Э. Екабсонс, Беларусы ў Латвіi, s. 207.

18 Latvijas Nacionālā arhīva Latvijas Valsts vēstures arhīvs (LVVA), P-712 f., 1 apr., 5 lieta, 9 Ip. 
kulturalnego i materialnego rozwoju ${ }^{19}$. Źródłem finansowania organizacji były składki członkowskie, datki ofiarodawców i dochody pochodzące ze sprzedaży książek. Najwyższym organem organizacji miał być zjazd ogólny członków, zwoływany raz do roku. Na zjeździe wybierano zarząd główny składający się z pięciu osób, z prezesem na czele. Zarząd główny sprawował władzę w okresie pomiędzy zjazdami. W rzeczywistości działalność Zrzeszenia Białoruskiego podlegała ścisłemu nadzorowi władz niemieckich ${ }^{20}$.

Czołowi działacze białoruscy na Łotwie wiązali z Niemcami duże nadzieje na osiągnięcie korzyści politycznych. Nastroje proniemieckie były powszechne w obozie białoruskim w przededniu i na pierwszym etapie II wojny światowej. W liście K. Jezawitaua do kolegi czytamy m.in.:

W pełni rozumiem, dlaczego rosyjscy carowie i bolszewicy próbowali zniszczyć Białorusinów. Rozumiem również przyczyny polskiej, łotewskiej i litewskiej agresji. Ale jestem pewien, że interesy polityczne państwa niemieckiego nie pokrywają się z rosyjskimi, polskimi, łotewskimi i litewskimi, a miejscowe władze niemieckie, o ile to oczywiście możliwe w tym momencie, będa wspierać Białorusinów w interesach politycznych obydwu tych narodów (niemieckiego i białoruskiego) ${ }^{21}$.

Jednocześnie lider łotewskich Białorusinów uważał, że wsparcia niemieckiego nie wystarczy, aby Białorusini „podnieśli się z kolan”. Działacz białoruski był przekonany, że ruch białoruski będzie się rozwijał pod okupacją niemiecką jedynie pod warunkiem, że sami Białorusini wykażą hart ducha i wolę walki².

Jedną z płaszczyzn aktywności Zrzeszenia Białoruskiego w Okręgu Generalnym Łotwa było życie kulturalne na terenie Łatgalii. Kierownictwo organizacji podjęło zakrojoną na szeroką skalę działalność mającą na celu utworzenie przy filiach amatorskich zespołów muzycznych i teatralnych ${ }^{23}$. Już wiosną $1942 \mathrm{r}$. powstał w Dyneburgu pierwszy białoruski amatorski zespół teatralny pod kierownictwem Jazepa Kamarżynskiego. Wkrótce założono również grupy teatralne w Indrze i Krasławiu. Zespołom brakowało jednak doświadczenia, w związku z czym z Witebska przybył Alaksandr Nowikow, reżyser Teatru Białoruskiego, dzięki któremu jesienią 1942 r. otworzono sezon teatralny w Dyneburgu, Indrze

19 Статут Беларускага аб’еgнаньня (у ген. кам. Латвіi), „Раніца”, 14.06.1942, s. 2-3.

20 J. Grzybowski, Zrzeszenie Białoruskie w Okręgu Generalnym Łotwa (1941-1945), „Przegląd Historyczny” 2018, t. 109, z. 1, s. 95-117.

21 Cyt. za: Э. Екабсонс, Беларусы ў Латвіi, s. 207.

22 НАРБ, ф. 458, воп. 1, спр. 22, л. 1.

23 НАРБ, ф. 458, воп. 1, спр. 40, л. 9. 
i Krasławie. Występy zespołów teatralnych i muzycznych cieszyły się dużą popularnością. Sukcesy zachęcały działaczy białoruskich do prac nad utworzeniem opery białoruskiej w Dyneburgu. Ta inicjatywa się jednak nie powiodła z powodu braku wystarczającej liczby zawodowych aktorów ${ }^{24}$.

Kierownictwo Zrzeszenia Białoruskiego podejmowało również próby wydania własnego periodyku25. W 1942 r. dyneburska filia Zrzeszenia Białoruskiego wyszła z inicjatywą wydawania gazety dla łotewskich Białorusinów, ukazującej się trzy razy w miesiącu ${ }^{26}$. Ani tych planów, ani podejmowanych później w 1943 r., nie udało się jednak zrealizować, przede wszystkim z powodu kłopotów finansowych ${ }^{27}$. Brak własnej prasy działacze białoruscy w Łatgalii starali się zrekompensować kolportażem wydawnictw białoruskich ukazujących się poza granicami Łotwy - w Berlinie, Mińsku, Białymstoku i Wilnie. Kładziono nacisk na kolportaż berlińskiego tygodnika „Ranica” („Poranek”), z którym ściśle współpracował prezes Zrzeszenia Białoruskiego. W periodyku tym istniał dział Życie białoruskie na Łotwie, w którym na bieżąco informowano o poczynaniach Zrzeszenia Białoruskiego ${ }^{28}$.

Na uwagę zasługuje również działalność wydawnicza Białorusinów na Łotwie. Z inicjatywą wydania literatury w języku białoruskim wyszedł K. Jezawitau²9. W połowie 1942 r. wśród nauczycieli szkół białoruskich rozpoczęła się zbiórka pieniędzy na wydanie literatury pięknej i podręczników szkolnych. Zdarzało się, że pedagodzy przekazywali znaczne kwoty. Latem 1943 r. w powiecie dyneburskim udało się zebrać 1500 marek $^{30}$. Pierwszą jaskółką było wydanie w 1943 r. w Rydze podręcznika Biełaruskaja Szkoła (Szkoła Białoruska) autorstwa K. Jezawitaua. Kierując się jednak względami komercyjnymi, za priorytet uznano wydanie literatury muzycznej. W rezultacie w 1943 r. w Rydze wydano 12 zeszytów białoruskich pieśni ludowych i romansów. Nakład każdego wydania wynosił kilka tysięcy egzemplarzy. Podejmowano także próby działalności naukowej. W marcu 1942 r. przy zarządzie głównym Zrzeszenia Białoruskiego w Rydze utworzono sekcję naukową (kierownikiem został K. Jezawitau). Podobna inicjatywa w Dyneburgu się jednak nie powiodła. W myśl zamiarów kierownictwa Zrzeszenia Białoruskiego praca sekcji naukowej miała służyć zachowaniu

\footnotetext{
24 J. Grzybowski, Zrzeszenie Białoruskie.

25 НАРБ, ф. 458, воп. 1, спр. 16, л. 17.

26 LVVA, P-712 f., 1 apr., 3 lieta, 3 Ip.

27 LVVA, P-712 f., 1 apr., 4 lieta, 31 lp.

28 LVVA, P-712 f., 1 apr., 6 lieta, 20 lp.

29 НАРБ, ф. 458, воп. 1, спр. 21, л. 20.

30 НАРБ, ф. 458, воп. 1, спр. 22, л. 29.
} 
i pielęgnowaniu kultury białoruskiej w Łatgalii. W związku z tym działalność naukowa organizacji polegała głównie na zbieraniu i opracowywaniu białoruskiej twórczości ludowej ${ }^{31}$.

Działacze Zrzeszenia Białoruskiego nie tracili z pola widzenia także kwestii religijnej w Łatgalii. Dążono do wprowadzenia języka białoruskiego do świątyń katolickich i prawosławnych w parafiach z przewagą ludności białoruskiej. Sprawa ta nie była jednak prosta, w liturgii Kościoła katolickiego na tych ziemiach dominował bowiem język polski. Z punktu widzenia działaczy białoruskich taki stan rzeczy był nie do przyjęcia. Jesienią 1941 r. zarząd główny BKN zwrócił się do biskupa Bolesława Słoskansa z memoriałem, w którym postulowano mianowanie w parafiach księży, którzy mogliby wygłaszać kazania i prowadzić katechizację w języku białoruskim. Memoriał spotkał się z aprobatą hierarchy, który obiecał wyjść naprzeciw oczekiwaniom działaczy białoruskich. Za słowami nie poszły jednak czyny. Białorusini nie przestawali ubiegać się o wprowadzenie języka białoruskiego do życia kościelnego łatgalskich katolików. Problem ten stał się przedmiotem obrad zarządu głównego Zrzeszenia Białoruskiego, które odbyło się 20 września 1942 r. Wówczas postanowiono ponownie wystosować apel do wyższej hierarchii kościelnej o skierowanie duchownych-Białorusinów do parafii z przewagą ludności białoruskiej. Próby białorutenizacji życia kościelnego w Łatgalii nie były niczym nowym, ponieważ już w okresie międzywojennym działacze białoruscy czynili zabiegi o wprowadzenie języka białoruskiego do świątyń katolickich. Z braku stosownych źródeł trudno jednoznacznie stwierdzić, jaki stosunek do wprowadzenia języka białoruskiego mieli wierni. Historia dostarcza przykłady ich zarówno pozytywnego, jak i negatywnego nastawienia do poczynań działaczy białoruskich. Co do księży, to tylko nieliczni zgłosili akces do ruchu białoruskiego, podczas gdy większość duchownych katolickich pozostawała głucha na hasła białoruskie ${ }^{32}$. W związku z tym próby wprowadzenia języka białoruskiego do świątyń katolickich i życia sakralnego wiernych nie odniosły większego skutku - przykładowo w większości szkół białoruskich zajęcia z katechezy katolickiej odbywały się po polsku33.

Część ludności białoruskiej na Łotwie należała do wyznania prawosławnego. Nie powinno więc dziwić, że działacze ze Zrzeszenia Białoruskiego usiłowali oddziaływać także na hierarchię prawosławną w kierunku białorutenizacji życia cerkiewnego, obawiając się wpływów zrusyfikowanego duchowieństwa prawosławnego na wiernych-Białorusinów. We wrześniu 1941 r. delegacja BKN

\footnotetext{
31 J. Grzybowski, Zrzeszenie Białoruskie.

32 НАРБ, ф. 458, воп. 1, спр. 16, л. 5.

33 BA, R 92/102, S. 78.
} 
spotkała się ze zwierzchnikiem Cerkwi prawosławnej w państwach bałtyckich, metropolitą Sergiuszem (Woskresienskim). Białorusini prosili hierarchę o obsadzenie parafii w miejscowościach z przewagą ludności białoruskiej księżmi narodowości białoruskiej ${ }^{34}$. Efektem tych zabiegów było mianowanie Białorusina ks. Michała Krawczenko proboszczem katedry pw. Zaśnięcia NMP w Dyneburgu. Duchowny ten był członkiem organizacji białoruskiej i wcześniej był katechetą w szkole białoruskiej w Rydze. Mimo to osiągnięcia działaczy białoruskich w kwestii wprowadzenia języka białoruskiego do cerkwi prawosławnych w Łatgalii były znikome. Wprawdzie część duchownych zgłosiła akces do Zrzeszenia Białoruskiego, trudno jednak jednoznacznie stwierdzić, jakie były tego rzeczywiste motywy. Można zaryzykować stwierdzenie, iż jednym z powodów były względy koniunkturalne i pragmatyczne. Przemawia za tym fakt, iż większość tych duchownych nie przejawiało większej aktywności, a ich udział w działalności organizacji sprowadzał się do biernego członkostwa.

Wydarzeniem, do którego działacze białoruscy przywiązywali dużą wagę, był spis ludności w Okręgu Generalnym Łotwa, przeprowadzony w lutym 1943 r. Z oczywistych względów zależało im na tym, żeby jak największa liczba mieszkańców okupowanej Łotwy podała narodowość białoruską. W prasie białoruskiej ukazującej się w Berlinie i Wilnie zaczęły się ukazywać artykuły, autorzy których zachęcali ludność do deklarowania się jako Białorusini. Prezes filii w Zilupe S. Sacharau zaproponował wydanie specjalnej ulotki dla chłopów, nawołującej ich do podania narodowości białoruskiej. W ramach agitacji wzmożono we wsiach działalność kulturalno-oświatową. W styczniu i lutym 1943 r. w powiatach dyneburskim i lucyńskim odbył się szereg koncertów i spektakli35. Kierownictwo Zrzeszenia Białoruskiego rozważało również możliwość zaproszenia do Łotwy znanego śpiewaka operowego Michała Zabejdy-Sumiskiego, który mieszkał w Pradze i był dobrze znany publiczności europejskiej. Zdaniem K. Jezawitau występy wybitnego tenora mogłyby się przyczynić do wzbudzenia u miejscowych chłopów dumy z bycia Białorusinem ${ }^{36}$.

Podczas spisu ludności uwidoczniły się rozbieżności pomiędzy działaczami białoruskimi i łotewskimi. Na łamach prasy białoruskiej pojawiła się informacja o tym, że łotewscy urzędnicy i policjanci wywierają naciski na chłopów białoruskich, żeby określali się jako Łotysze. Działacze białoruscy zarzucali administracji łotewskiej dążenie do asymilacji ludności białoruskiej. 30 stycznia 1943 r. Aliaksandr Machnouski w liście do K. Jezawitaua wyraził przekonanie,

\footnotetext{
34 НАРБ, ф. 458, воп. 1, спр. 20, л. 20 зв.

35 НАРБ, ф. 458, воп. 1, спр. 35, л. 27.

36 НАРБ, ф. 458, воп. 1, спр. 12, л. 3.
} 
że wyniki spisu ludności nie będą odzwierciedlać stanu realnego, ponieważ żaden Białorusin nie był członkiem komisji spisowej37. Kierownik filii Zrzeszenia Białoruskiego w Krasławiu narzekał w lutym 1943 r. na postawę władz gminnych, które odmówiły włączenia do komisji reprezentanta ludności białoruskiej. Podobnie sytuacja wyglądała w pozostałych miejscowościach i gminach Łatgalii, w których mieszkali Białorusini. W marcu 1943 r. nauczyciel białoruski Ignacy Błażewicz w nastepujący sposób charakteryzował przebieg spisu:

Spis powszechny przebiegł u nas bardzo cicho, bez udziału inteligencji białoruskiej. Narodowość białoruska podało wielu ludzi, lecz nie jestem pewien, co z tym zrobiq komisje, w składzie których w ogóle nie było Białorusinów38.

Strona białoruska obawiała się, że działania administracji łotewskiej spowodują zmniejszenie liczby deklaracji narodowości białoruskiej. Na początku 1943 r. K. Jezawitau i A. Machnouski wystosowali dwa memoriały: do władz Okręgu Generalnego Łotwa i komisarza okręgowego w Dyneburgu, prosząc o nietraktowanie poważnie wyników spisu dotyczących liczebności Białorusinów, gdyż rzeczywista ich liczba na Łotwie musi być większa39

Obawy działaczy białoruskich okazały się jednak niezasadne, wyniki spisu były bowiem na ogół satysfakcjonujące dla Białorusinów. Narodowość białoruską podało 48601 osób (2,76\% ogółu mieszkańców), z czego 6669 w Rydze, reszta w Łatgalii. Wśród deklarujących się jako Białorusini znajdowali się zarówno przedstawiciele ludności autochtonicznej, jak i przybysze z innych krajów. Wśród tych ostatnich byli polscy robotnicy sezonowi oraz uchodźcy wojenni ze wschodniej Białorusi. Znamienne jest to, że przeszło 21 tys. podało narodowość białoruską i jednocześnie język rosyjski jako używany na co dzień. Na podstawie wyników analizy tego spisu można stwierdzić, że liczba mieszkańców Łotwy deklarujących narodowość białoruską nie uległa większym zmianom i była porównywalna do tej w okresie międzywojennym, pomiędzy latami 1925 a 1930. Trudno jednoznacznie określić, w jakim stopniu wpływ na wyniki spisu wywarła wspomniana wcześniej aktywność działaczy Zrzeszenia Białoruskiego. Czy deklarowanie narodowości białoruskiej wynikało z ukształtowanego poczucia przynależności do narodu białoruskiego? Biorąc pod uwagę przedwojenną obecność w tym kraju białoruskich organizacji kulturalno-oświatowych i politycznych, nie ulega wątpliwości, że w odniesieniu do części włościaństwa łatgalskiego był to główny

37 НАРБ, ф. 458, воп. 1, спр. 33, л. 19.

38 НАРБ, ф. 458, воп. 1, спр. 29, л. 30.

39 НАРБ, ф. 458, воп. 1, спр. 16, л. 5. 
powód podawania narodowości białoruskiej. Pewne jest również i to, że część mogła podawać się za Białorusinów, kierując się względami koniunkturalnymi. Władze niemieckie nie czyniły przeszkód Białorusinom, więc manifestowanie białoruskości wśród mieszkańców Łatgalii nie było niemile widziane.

Obok inicjatyw stricte kulturalno-oświatowych podejmowano także próby organizacji białoruskich oddziałów zbrojnych w służbie niemieckiej, przeznaczonych do walki z partyzantką sowiecką. Okupanci wykorzystywali ludność miejscową do swoich celów obronnych. Tworzono policję pomocniczą (Schutzmannschaft) i inne oddziały zbrojne złożone z ludności miejscowej. Wcielano do nich zarówno Łotyszy, jak i przedstawicieli innych narodowości. Ogólne dowództwo sprawowali Niemcy, lecz oficerowie i podoficerowie rekrutowali się spośród kadry przedwojennej armii łotewskiej i policji. Żołnierze tych formacji nosili niemieckie mundury, lecz posiadali łotewskie oznaki narodowe. Działacze Zrzeszenia Białoruskiego uważali, że łotewscy Białorusini nie powinni być wcielani do tych oddziałów. Postulowano potrzebę formowania na Łotwie oddziałów wojskowo-policyjnych złożonych wyłącznie z Białorusinów, którymi dowodziliby oficerowie tejże narodowości. W latach 1942-1944 kierownictwo organizacji niejednokrotnie zwracało się do władz niemieckich o zgodę na formowanie oddziałów białoruskich na Łotwie. 27 maja 1943 r. K. Jezawitau zaproponował kierownikom poszczególnych filii Zrzeszenia Białoruskiego, aby przystąpić do omówienia możliwości tworzenia $w$ Łatgalii białoruskich wartownicznych kompanii i batalionów. Działacz twierdził, że brak formacji białoruskich sprawia, że miejscowa ludność białoruska jest bezbronna i dlatego łatwo pada ofiarą ataków partyzantów sowieckich. Mimo starań działaczy białoruskich władze okupacyjne nie wyraziły zgody na formowanie na Łotwie oddziałów białoruskich, a młodzież białoruska była wcielana do oddziałów łotewskich pod dowództwem niemieckim. Z upływem czasu zjawisko to przybrało na sile. Zwłaszcza od połowy 1943 r., kiedy przystąpiono do formowania Łotewskiego Legionu SS, w szeregach którego znalazło się wielu łatgalskich Białorusinów ${ }^{40}$.

Nie ulega wątpliwości, że priorytetem miejscowych działaczy białoruskich była organizacja szkolnictwa w Łatgaliii ${ }^{41}$ Już 20 października 1941 r. kierownictwo BKN przedstawiło generalnemu komisarzowi projekt otwarcia pierwszych dziewięciu szkół białoruskich ${ }^{42}$. Władze okupacyjne przychylnie ustosunkowały się do poczynań Białorusinów. Zakładano, że dzieci Białorusinów nie powinny uczęszczać do szkół łotewskich i na odwrót. 22 października 1941 r. komisarz

\footnotetext{
40 J. Grzybowski, Zrzeszenie Białoruskie.

41 BA, R 92/101, S. 59-63.

42 BA, R 92/102, S. 57-58.
} 
generalny Łotwy wydał rozporządzenie nakazujące organizację szkół białoruskich. W liście departamentu oświaty i kultury Ministerstwa do spraw Okupowanych Terenów Wschodnich z 26 listopada 1941 r. czytamy m.in.:

po ponownym otwarciu łotewskich szkół istnieje potrzeba otworzyć również szkoły ludowe dla rosyjskiej i białoruskiej grup narodowych na Łotwie. Na podstawie przedłożonych sprawozdań zarząd szkolnictwa łotewskiego prowadzi w Komisariacie Rzeszy Wschód niekorzystną politykę łotyszyzacji wobec rosyjskich i białoruskich grup narodowych. W przypadku ponownego otwarcia szkół białoruskich i rosyjskich należy zwrócić uwagę na to, że do tej pory w licznych miejscowościach z przewaga ludności rosyjskiej i białoruskiej powstawały tylko szkoły łotewskie. Na ich miejscu teraz będq otwarte rosyjskie i ewentualnie białoruskie szkoły. W przypadku szkół rosyjskich nauczanie będzie trwało 3 lata (8-11 rok życia), białoruskich - 4 lata (8-12). W przypadkach istnienia szkół łotewskich dla dzieci rosyjskich i białoruskich, maja one zostać przekształcone $w$ rosyjskie i białoruskie. W środowiskach mieszanych językowo decyzja będzie podejmowana na korzyść szkół białoruskich ${ }^{43}$.

Sprawy związane z organizacją szkolnictwa znajdowały się w gestii referenta oświaty i kultury Okręgu Generalnego Łotwa Franza Adolphiego. We współpracy z kierownictwem BKN urzędnik ten wyznaczył emisariuszy, którzy mieli przystąpić do rejestracji uczniów. Działacze BKN dążyli do otwarcia szkół białoruskich przede wszystkim w miejscowościach, gdzie istniało szkolnictwo białoruskie w okresie międzywojennym. W celu rejestracji uczniów do powiatu dyneburskiego udali się Mikałaj Dziamidau i Jazep Kamarżynski ${ }^{44}$, do powiatu lucyńskiego - Siarhiej Sacharau i Symon Maciejeuski ${ }^{45} .24$ października 1941 r. M. Dziamidau został oficjalnie mianowany pełnomocnikiem do spraw organizacji szkolnictwa białoruskiego w okręgu dyneburskim ${ }^{46}$. Działalność M. Dziamidaua można uznać za ze wszech miar owocną. W gminie Indra udało mu się zarejestrować blisko 1 tys. uczniów. W Dyneburgu rejestrację prowadził A. Machnouski, który zebrał 540 podań od rodziców chcących posłać swoje dzieci do szkół białoruskich. Rejestracja uczniów dobiegła końca w połowie listopada 1941 r., po czym kierownictwo BKN przekazało F. Adolphiemu informację na temat możliwości utworzenia szkół białoruskich w powiatach dyneburskim, lucyńskim i iłuksztańskim ${ }^{47}$.
43 BA, R 92/102, S. 7.
44 BA, R 92/101, S. 70.
45 BA, R 92/102, S. 70.
46 BA, R 92/101, S. 156.
47 BA, R 92/102, S. 83-85. 
Szkolnictwo białoruskie na Łotwie mogło istnieć na zasadach obowiązujących na obszarze okupowanych państw bałtyckich. Na tym terenie przewidziano otwarcie trzech typów szkół. Najbardziej rozpowszechnione były podstawowe szkoły ludowe (Volksschulen), które dzieliły się na 5- i 7-klasowe. Absolwenci tych szkół mogli kontynuować naukę w 4-klasowych szkołach średnich (Mittelschulen). Oprócz tego istniały także 2- i 3-klasowe szkoły zawodowe (Berufsschulen, Fachschulen), które były: rzemieślnicze, handlowe, rolnicze i administracyjne ${ }^{48}$.

Z myślą o ułatwieniu zarządzania szkołami powołano stanowisko inspektora szkół białoruskich w Łatgalii i Zemgalii49. 1 grudnia $1941 \mathrm{r}$. stanowisko to objął M. Dziamidau. Po jego wyjaździe z Dyneburga w lutym 1942 r. inspektorem został A. Machnouski, który piastował tę funkcję aż do końca okupacji niemieckiej. Inspektor szkół białoruskich podlegał referentowi oświaty i kultury w zarządzie komisarza okręgowego w Dyneburgu Rolfowi Winbergowi. 1 stycznia 1942 r. przy generalnej dyrekcji oświaty i kultury Łotwy utworzono stanowisko referenta szkolnictwa białoruskiego, które powierzono P. Miranowiczowi ${ }^{50}$. Główny ciężar organizacji szkół białoruskich na Łotwie spoczął na inspektorze i referencie oraz kierownictwie BKN (później Zrzeszenia Białoruskiego) ${ }^{51}$.

Zezwolenie na otwarcie szkół wydawał generalny dyrektor oświaty i kultury na wniosek referenta szkolnictwa białoruskiego. Zgodnie z rozporządzeniem referenta oświaty w Dyneburgu szkoły białoruskie mogły być otwarte w miejscowościach, w których było co najmniej 45 uczniów. W przypadku mniejszej liczby chętnych można było utworzyć grupy białoruskie w szkołach łotewskich lub rosyjskich ${ }^{52}$. W pierwszym roku niemieckiej okupacji Łotwy otwarto 32 białoruskie szkoły podstawowe, do których uczęszczało około 3 tys. uczniów. W kolejnym roku liczba tych szkół wyniosła już 35. W roku szkolnym 1942/43 do białoruskich szkół ludowych w Łatgalii i Zemgalii uczęszczało 3432 uczniów 1802 chłopców i 1630 dziewczynek ${ }^{53}$. Wiekszość szkół znajdowała się w powiatach dyneburskim i lucyńskim. W tym regionie odnotowano największy odsetek ludności białoruskiej. Akcja szkolna odniosła najlepszy wynik w powiecie dyneburskim, gdzie już w grudniu 1941 r. prace nad organizacją szkół były na

48 BA, R 6/402, S. 13-16.

49 LVVA, P-712 f., 1 apr., 6 lieta, 5 Ip.

50 Беларускае жыцьцё ў Латвіі, „Раніца”, 22.02.1942, s. 3-4; Э. Екабсонс, Беларусы у Латвіi, s. 210-211.

51 НАРБ, ф. 458, воп. 1, спр. 21, л. 1.

52 BA, R 92/102, S. 101.

53 BA, R 92/102, S. 231-232. 
zaawansowanym etapie. W roku szkolnym 1942/43 w tym powiecie działało 19 białoruskich szkół ludowych, z czego najwięcej było w gminach Indra i Pustyne ${ }^{54}$. Łącznie w powiecie dyneburskim do białoruskich szkół podstawowych chodziło 2178 uczniów ${ }^{55}$. Nieco później niż w powiecie dyneburskim przystąpiono do organizacji szkolnictwa białoruskiego na terenie powiatu lucyńskiego. W marcu 1942 r. do Lucyny został oddelegowany M. Dziamidau ${ }^{56}$, któremu do września tegoż roku udało się otworzyć 6 szkół ludowych ${ }^{57}$. Działacze białoruscy podejmowali próby rozciągnięcia akcji szkolnej na powiat rzeżycki Łatgalii. W tym celu wiosną 1942 r. kierownictwo BKN wyszło z inicjatywą otwarcia pierwszych szkół $w$ tym powiecie. Wyznaczono nawet pełnomocnika do spraw organizacji szkolnictwa białoruskiego, którym został P. Jurkiewicz. Nie otrzymano jednak zgody Niemców na otwarcie szkół białoruskich w tym powiecie ${ }^{58}$.

Za sukces miejscowych działaczy białoruskich należy uznać utworzenie dwóch szkół średnich (gimnazjów). Pierwsze gimnazjum białoruskie (dyrektorem został S. Sacharau, potem Aliaksandr Rodźka) utworzono w Indrze w grudniu 1941 r. W roku szkolnym 1941/42 otwarto dwie młodsze klasy (dla 74 osób) ${ }^{59}$. Przy szkole powstał internat (30 miejsc) dla uczniów pochodzących z odległych wsi. Drugie gimnazjum białoruskie (tu dyrektorem został także S. Sacharau) utworzono w Zilupe w roku szkolnym 1942/4360. Kierownictwo Zrzeszenia Białoruskiego uznało, że do gimnazjów będą mogły uczęszczać nie tylko dzieci łotewskich Białorusinów, lecz także ich pobratymców z Siebieża $(\text { Rosji })^{61}$. Z powodu krótkiego okresu istnienia gimnazja nie doczekały się egzaminów maturalnych. W Indrze klasa maturalna rozpoczęła pracę dopiero w roku szkolnym 1943/44, który okazał się ostatnim rokiem istnienia szkoły. Tymczasem w Zulupe w roku szkolnym 1944/45 miała zostać otwarta klasa maturalna, co nigdy nie nastąpiło ${ }^{62}$. Próbowano również otworzyć gimnazja białoruskie w Dyneburgu i Pasiene. Próby te nie przyniosły jednak oczekiwanych rezultatów. Niemniej jednak w 1942 r. w Pasiene rozpoczęła pracę średnia szkoła

\footnotetext{
54 Э. Екабсонс, Беларусы ў Латвіі, s. 226-232.

55 BA, R 92/102, S. 231.

56 Беларускае жыцьцё ў Лацьвіі, „Раніца”, 29.03-5.04.1943, s. 5.

57 BA, R 92/102, S. 156.

58 LVVA, P-712 f., 1 apr., 6 lieta, 3 Ip.

59 НАРБ, ф. 458, воп. 1, спр. 35, л. 40.

60 НАРБ, ф. 458, воп. 1, спр. 17, л. 23.

61 НАРБ, ф. 458, воп. 1, спр. 23, л. 21.

62 Беларускае жыцьцё ў Лацьвіi, „Раніца”, 21.02.1943, s. 3
} 
rolnicza, do której przyjęto 102 uczniów ${ }^{63}$. Pierwsi maturzyści otrzymali dyplomy 6 kwietnia 1944 r. ${ }^{64}$.

Pomimo sprzyjającej Białorusinom koniunktury politycznej praca szkolnictwa białoruskiego napotykała pewne przeszkody. Aktywność białoruska wywołała niezadowolenie wielu Łotyszy. Stosunek administracji łotewskiej do białoruskiej akcji szkolnej był nacechowany nieufnością, a nawet wrogością. Zdarzało się, że łotewski inspektorat szkolny odmawiał rejestracji niektórych szkół białoruskich. 8 października 1941 r. delegacja białoruska w składzie P. Miranowicza i Jakuba Kastyluka złożyła do F. Adolphiego skargę na łotewskiego inspektora szkolnego, oskarżając go o stronniczość i kwestionowanie zasadności otwarcia szkół białoruskich w gminach dyneburskiej, piedrujskiej i pustynskiej. Działacze białoruscy twierdzili, że Łotysze, zasłaniając się rzekomym brakiem wytycznych od Niemców, celowo zwlekali z otwarciem szkół białoruskich. W związku z tym strona białoruska prosiła o wydanie rozporządzenia, które zmusiłoby inspektora-Łotysza do otwarcia szkół białoruskich w miejsce dawnych rosyjskojęzycznych szkół sowieckich. Ponadto delegacja białoruska zabiegała o to, żeby Niemcy powstrzymali zwolnienia nauczycieli-Białorusinów ${ }^{65}$. Pomiędzy działaczami białoruskimi i łotewskimi zarysowywały się różnice na tle stosunku do sytuacji narodowościowej Łatgalii. Z białoruskiego punktu widzenia szereg gmin w powiecie dyneburskim i lucyńskim było częścią białoruskiego obszaru etnograficznego. Źródła białoruskie mówiły o tym, że Białorusini mieli tam stanowić nawet 90\% ogółu mieszkańców. Otwarcie na tym terenie szkół białoruskich traktowano jako akt sprawiedliwości wobec Białorusinów i rodzaj zadośćuczynienia za likwidację szkolnictwa białoruskiego po 1934 r. Tymczasem działacze łotewscy nie podzielali tego poglądu. Dla części łotewskich elit intelektualnych Białorusini byli „zesłowianizowanymi Łotyszami”, których należało odzyskać dla narodu łotewskiego. Łotewski inspektorat szkolny obarczał działaczy białoruskich winą za wywołanie zamieszania i niepokojów w mieszanych narodowościowo rejonach Łatgalii. Zarzucano im nadużycia i niechlujność podczas organizowania szkolnictwa. W szczególności stronie łotewskiej naraził się M. Dziamidau. Głośnym echem odbił się incydent, do którego doszło w Indrze w listopadzie 1941 r. W tej miejscowości istniała szkoła łotewska, lecz wkrótce otwarto też szkołę białoruską, której dyrektorem został właśnie M. Dziamidau. Łotewski inspektorat szkolny złożył do F. Adolphiego skargę na Dziamidaua. Łotysze uważali, że ten działacz białoruski uciekał się do zastraszania

\footnotetext{
63 BA, R 92/102, S. 175.

64 Беларускае жыцьцё ў Лацьвіі, "Раніца" 21.05.1944, s. 3.

65 BA, R 92/102, S. 69.
} 
i gróźb, aby zmusić rodziców do wysyłania swoich dzieci do szkoły białoruskiej. Strona łotewska twierdziła, że 3 listopada 1941 r. M. Dziamidau zjawił się w szkole łotewskiej i oznajmił, że odtąd zamiast szkoły łotewskiej będzie białoruska. Przy czym miał zagrozić rodzicom, że w przypadku odmowy wysyłania dzieci do szkoły białoruskiej, spotka ich kara. Podczas spotkania z rodzicami działacz białoruski miał powiedzieć, że Łotysze wkrótce zostaną przesiedleni do Kurlandii i Liflandii, bo aż po Dyneburg będzie Białoruś. Dlatego wszystkie miejscowe dzieci muszą chodzić do szkoły białoruskiej, bo tylko wtedy unikną wysiedlenia ${ }^{66}$.

Dyrektor generalnej dyrekcji stanął na stanowisku, że samowola M. Dziamidaua jest niedopuszczalna i podważa autorytet oraz zaufanie ludzi do Niemców. W związku z powyższym uważał, że należy podjąć następujące kroki w celu przywołania do porządku Białorusinów i zapobieżenia podobnym incydentom w przyszłości:

1) W gminach, w których Białorusini chcą otworzyć swoje szkoły, należy powołać mieszane komisje składające się z przedstawicieli Łotyszy, Białorusinów i Niemców. Celem tych komisji będzie zbadanie sytuacji narodowościowej. Rodzice powinni złożyć pisemne deklaracje określające narodowość swoich dzieci. Na podstawie tych deklaracji komisja zdecyduje, do jakiej szkoły wysłać uczniów.

2) Rodziców powinno się zapoznać z rozporządzeniem referenta szkolnictwa Okręgu Generalnego Łotwy w sprawie organizacji szkolnictwa dla poszczególnych narodowości. Komisje powinny czuwać, żeby rodzice nie mylili narodowości z wyznaniem religijnym.

3) W szkołach białoruskich powinno się zatrudniać wyłącznie nauczycieli narodowości białoruskiej, zaś w łotewskich - tylko łotewskiej ${ }^{67}$.

Łotewska administracja szkolna niejednokrotnie podejmowała próby zamknięcia szkół białoruskich ${ }^{68}$. W październiku 1942 r. zarząd gminy skajckiej domagał się od inspektoratu szkolnego w Dyneburgu zamknięcia szkoły we wsi Kalniesi. Strona łotewska twierdziła, że szkoła nie powinna działać, ponieważ Białorusini wprowadzili wszystkich w błąd, dostarczając fałszywą listę uczniów, których jeszcze nie było, a dopiero potem zaczęli agitację wśród chłopów, namawiając ich, żeby wysyłali swoje dzieci do szkoły białoruskiej. Podobne sytuacje miały miejsce w wielu miejscowościach, w których obok szkoły łotewskiej istniała białoruska. Atmosferę niezdrowej rywalizacji pokazuje

\footnotetext{
66 BA, R 92/102, S. 77.

67 BA, R 92/102, S. 79.

68 НАРБ, ф. 458, воп. 1, спр. 31, л. 3-4 зв.
} 
korespondencja pomiędzy poszczególnymi działaczami białoruskimi. W czerwcu 1942 г. dyrektor szkoły białoruskiej w powiecie lucyńskim pisał do kierownika Zrzeszenia Białoruskiego:

Toczyłem walkę z Łotyszami, którzy dokładali wszelkich starań, by zamknąć nasza szkołę, lecz nic z tego nie wyszło. Wyszedłem z tej walki obronna ręką. Teraz czekam, aż szkołę łotewską szlag trafíi.

Powyższe nieporozumienia były odzwierciedleniem szerszych problemów, które już wcześniej występowały w Łatgalii.

Aktywność białoruska ożywiła obawy Łotyszów o integralność terytorialną ich kraju. Zaniepokojenie strony łotewskiej nie było pozbawione racjonalnych podstaw, ponieważ czołowi działacze białoruscy na Łotwie liczyli na to, że po wojnie Niemcy zdecydują się na włączenie „białoruskich” gmin Łatgalii do Białorusi. Uważali, że bieżąca sytuacja polityczna stwarza przed nimi szansę na umocnienie swojej pozycji kosztem Łotyszów. Zarówno działacze białoruscy, jak i łotewscy zdawali sobie sprawę, że od sytuacji narodowościowej w Łatgalii może zależeć przynależność państwowa tego regionu. W związku z tym obie strony aktywnie prowadziły akcję zbierania wśród rodziców podpisów, żeby zapisywali swoje dzieci do szkół narodowych. W zasadzie organizacja szkolnictwa białoruskiego odbywała się za cenę częściowej likwidacji szkół łotewskich. Działacze białoruscy nie wahali się przejmować te placówki, które potem były przekształcane w szkoły białoruskie. Szkoły traktowano nie tylko jako placówki edukacyjne, lecz także jako przyczółki w walce o to, do kogo w przyszłości będzie należeć mieszany narodowościowo region. Kierownik BKN K. Jezawitau nie wątpił w to, że miejscowości, w których będą szkoły białoruskie, w nieodległej przyszłości znajdą się w granicach Białorusi ${ }^{70}$. W liście do inspektora szkół białoruskich K. Jezawitau pisał m.in.:

Granic obecnie nie ma i nikt nie wie gdzie one będq przebiegać. A będq one tam, gdzie będziemy stanowić większość! Może się wydarzyć, że to ci krzykacze [Łotysze - J.G.] będa musieli wyjechać, a nie my!1

Nastroje panujące wśród działaczy białoruskich oddają również inne słowa K. Jezawitaua, który w październiku 1941 r. pisał do kierowników BKN w Dyneburgu:

\footnotetext{
69 НАРБ, ф. 458, воп. 1, спр. 33, л. 28.

70 НАРБ, ф. 458, воп. 1, спр. 16, л. 2.

71 LVVA. P-712 f., 1 apr., 6 lieta, 4 lp.
} 
Cofać się nie warto, nie wolno, a nawet małodusznie. Może dojść do sytuacji, kiedy w niektórych gminach będziemy musieli przejąć wszystkie szkoły. Co wtedy, też będziemy się bawić w dyplomację? W imię obrony interesów własnego narodu nie możemy okazywać chwiejności. Uczmy się od Łotyszy i Niemców. Wszyscy nas ciemiężyli, bo byliśmy za dużo dyplomatyczni².

Napięcie rosło i obie strony nie powstrzymywały się przed stosowaniem wszystkich dostępnych środków. I Łotysze, i Białorusini realizowali własne interesy, stosując politykę faktów dokonanych. Jednym z narzędzi rywalizacji była denuncjacja u Niemców. Każda ze stron usiłowała przedstawić adwersarzy w jak najgorszym świetle. W maju 1942 r. K. Jezawitau wystosował memoriał do F. Adolphiego, wyliczając krzywdy wyrządzone Białorusinom przez administrację i policję łotewską. Na łamach prasy białoruskiej ukazującej się w Berlinie i Mińsku kierownik Zrzeszenia Białoruskiego rzucał gromy pod adresem Łotyszów, oskarżając ich o dążenie do asymilacji ludności białoruskiej w Łatgalii. Pisał o mrzonkach o mocarstwowość z czasów masona Ulmanisa, na które, jego zdaniem, cierpi część społeczeństwa łotewskiego. Niewątpliwie takie sformułowania były krzywdzące dla strony łotewskiej. Tymczasem z analizy donosów łotewskich wynika, że ich autorzy przedstawiali Białorusinów jako zagorzałych i konsekwentnych zwolenników komunizmu ${ }^{73}$. Niekiedy autorzy tych artykułów posuwali się jeszcze dalej, próbując dowieść nieistnienia Białorusinów na Łotwie i negując ich prawo do posiadania własnych szkół. Starosta gminny w powiecie dyneburskim Andris Luta podawał, że pod koniec XIX w. większość mieszkańców stanowili Łotysze, którzy częściowo zapomnieli swój język ojczysty i rozmawiają w różnych dialektach języka rosyjskiego i pod wpływem pewnej agitacji podaja się za Białorusinów ${ }^{74}$.

W aktach Oddziału Kultury i Oświaty Okręgu Generalnego Łotwa znajduje się notatka zatytułowana Czy sq̨ Białorusini na Łotwie, w której czytamy m.in.:

Wcześniej z Białorusinami w ogóle nie liczono się zarówno za czasów rosyjskich, jak i łotewskich, i nikt nie wiedział, że na Łotwie taki naród istnieje. Również obecni „Białorusini” nic o tym nie wiedzieli i uważali się za Rosjan, Łotyszów albo Polaków. „Białorusini” zostali tutaj odkryci dopiero w 1925 r. a mianowicie przez socjaldemokratyczna i komunistyczna partię łotewskiego sejmu. Wtedy w Rosji Sowieckiej została utworzona autonomia białoruska i komuniści z Mińska zwrócili się do ryskich marksistów z prośbq̨ o zarejestrowanie Białorusinów również na Łotwie. Białorusinami

72 НАРБ, ф. 458, воп. 1, спр. 16, л. 2.

73 BA, R 92/102, S. 77-79.

74 Cyt. za: Э. Екабсонс, Беларусы ў Латвіi, s. 219-220. 
opiekował się najbardziej marksistowski poeta Rainis [sic! - J.G.], który jako minister oświaty dopuścił do otwarcia pierwszych szkół białoruskich (z rosyjskim jako językiem nauczania). Również Rosjanie powitali „ruch białoruski”, ponieważ ten ruch był faktycznie rosyjski. Katoliccy Białorusini uczęszczali do szkół łotewskich i nie chcieli do rosyjskich, ponieważ tam były dzieci prawosławne i staroobrzędowcy w przeciwieństwie do szkół łotewskich w Łatgalii, gdzie dzieci uważane były za katolików. Nowo utworzone „białoruskie” szkoły były zatem rosyjsko-katolickie, mogły przyciagać katolickie dzieci i je rusyfikować. Kiedy w 1940 r. do władzy doszli komuniści, otworzyli oni wiele nowych białoruskich szkół. Faktycznie ruch białoruski na Łotwie jest rosyjsko-imperialny, z silnym zabarwieniem komunistycznym. Był od zawsze wspierany z Moskwy, prawie wszyscy białoruscy działacze na Łotwie byli komunistami, również nauczyciele. „Białoruska mniejszośc” na Łotwie uchodziła za zupełnie „czerwona”, podobnie jak żydowska. Również teraz należy tutejszych świadomych „Białorusinów” uznać za przyczółek Moskwy i komunizmu. Ponieważ komuniści nie moga tutaj często pojawiać się, zatem chca oni ukryć się pod narodowym płaszczykiem. Polityczna niepewność wzrosła u nas, zwłaszcza w pogranicznej Łatgalii. Kulturalnie oznaczałoby to rusyfikację i zbliżenie się do Rosji, co przecież nie odpowiadałoby idei wielkich Niemiec. Ponowne pojawienie się „kwestii białoruskiej” wywołało wśród narodu łotewskiego bolesne wrażenie. Przecież prowadzimy wspólną historyczna bitwę przeciwko barbarzyńskiemu wrogowi. Rosjanie zamordowali 30000 Łotyszy i wywieźli, w Rosji wymordowano setki tysięcy Niemców, a w tym samym czasie powstaje bastion Moskwy i Słowiańszczyzny na Łotwie. Cała Białoruś była kiedyś zamieszkała przez bałtycko-germańskie ludy, które na przestrzeni tysięcy lat zostali zrusyfikowani. I teraz na czystych łotewskich ziemiach coraz bardziej na zachód tworzy się nowy przyczótek rusyfikacji 75 .

Za słowami szły także czyny. Historia dostarcza nam wielu przykładów, kiedy nauczyciele białoruscy byli prześladowani przez administrację cywilną i policję pomocniczą. Część pedagogów objęto akcją wywozu na prace przymusowe. Co najmniej kilkunastu nauczycieli padło ofiarą tych działań. Zdarzało się, że niektórzy nauczyciele byli zatrzymywani kilkakrotnie. Dochodziło do aktów szantażu i zastraszania, aby zmusić pedagogów do rezygnacji z dalszej pracy w szkołach białoruskich. Często Białorusinów poddawano represjom pod zarzutem sympatyzowania z władzą sowiecką. Zarzucano im współpracę z komunistami po inkorporacji Łotwy do ZSRS. Generalna dyrekcja oświaty wskazywała na obecność w szkołach białoruskich nauczycieli, którzy w przeszłości skompromitowali się współpraca z władzą sowiecką. W związku z tym domagano się relegowania ze szkół osób o wątpliwej przeszłości. Kilkakrotnie

${ }^{75}$ BA, R 92/102, S. 93-96. 
działacze BKN zabiegali u władz niemieckich o uwolnienie zatrzymanych nauczycieli i przywrócenie ich do pracy w szkolnictwie ${ }^{76}$.

Do białoruskiej akcji szkolnej wrogo byli również nastawieni miejscowi działacze rosyjscy. Należy zaznaczyć, że stosunki białorusko-rosyjskie w tym regionie nigdy nie układały się pomyślnie. Rosjanie stanowili najliczniejszą grupę mniejszościową w Łatgalii. Inteligencja rosyjska przejawiała nastroje antykomunistyczne, w związku z czym władze III Rzeszy zgodziły się na utworzenie autonomii szkolnej dla mniejszości rosyjskiej ${ }^{77}$. Obiektem agitacji narodowej działaczy rosyjskich i białoruskich była wieś łatgalska mówiąca różnymi dialektami języków słowiańskich. W związku z tym, że ludność ta nie miała wykrystalizowanego poczucia świadomość narodowej, była podatna na agitację zarówno białoruską, jak i rosyjską. Oba obozy narodowe usiłowały objąć swoją akcją szkolną jak największą liczbę osób niezależnie od ich narodowości i religii. Pomiędzy działaczami białoruskimi i rosyjskimi występowały różnice w postrzeganiu sytuacji narodowościowej Łatgalii. Działacze białoruscy traktowali jako Białorusinów wszystkich, którzy w domu mówili gwarą białoruską. Tymczasem działacze rosyjscy tradycyjnie uważali ludność białoruską za odłam narodu rosyjskiego. Kamieniem niezgody stali się także staroobrzędowcy, którzy tworzyli stosunkowo liczną grupę w Łatgalii. Przywódcy ruchu białoruskiego próbowali nawiązać kontakt z przywódcami starowierców, żeby nakłonić ich do zaangażowania się w białoruską akcję szkolną ${ }^{78}$. Działacze białoruscy uważali, że większość łatgalskich staroobrzędowców to „zrusyfikowani Białorusini”79. Apele przywódców białoruskich nie spotkały się z odzewem społeczności staroobrzędowskiej, chociaż znane są pojedyncze przypadki, kiedy starowiercy zgłaszali akces do Białorusinów ${ }^{80}$.

W Łatgalii trwała ostra rywalizacja pomiędzy działaczami białoruskimi a rosyjskimi o „serca i dusze” miejscowej młodzieży szkolnej. Szkoły rosyjskie powstawały w tym samym czasie i na tym samym terenie, co i białoruskie. Z korespondencji działaczy białoruskich z niemieckimi władzami okupacyjnymi wynika, że strona białoruska kwestionowała zasadność otwierania szkół rosyjskich w miejscowościach z przewagą ludności białoruskiej. W jednym z listów do F. Adolphiego z 20 listopada 1941 r. prezes BKN pisał m.in.:

\footnotetext{
76 BA, R 92/102, S. 102.

77 BA, R 92/103, S. 70-71, 178-179.

78 LVVA, P-712 f., 1 apr., 6 lieta, 1-2 Ip.

79 LVVA, P-712 f., 1 apr., 6 lieta, 4 lp.

80 LVVA, P-712 f., 1 apr., 6 lieta, 4 lp.
} 
Uważam za swój obowiązek zwrócić uwagę Pana na to, że w Rydze i Dyneburgu wielu dyrektorów szkół rosyjskich przyjmuje do swoich szkół uczniów, których rodzice sq Białorusinami, co potwierdzają dokumenty mówiq̨ce o tym, że oni pochodza z guberni białoruskich. Dzieci i ich rodzice bezsprzecznie sq Białorusinami i dlatego nie powinny być przyjmowane do szkół rosyjskich. W celu pominięcia narodowości i wprowadzenia zamętu, Wielkorusi określaja swoje szkoły mianem „ruskie”, do których moga być przyjmowani i Wielkorusi, i Białorusini, i Ukraińcy. W ślady Wielkorusów idą łotewskie zarządy szkolne, które określaja szkoły wielkoruskie mianem szkół ruskich, co wprowadza niejasność. W związku z tym proszę o to, by szkoły wielkoruskie nie nazywano szkołami ruskimi, a wielkoruskimi i żeby do tych szkół nie byli przyjmowani Białorusini. Należy również zwrócić uwagę na to, że w powiatach iłuksztańskim, dyneburskim i lucyńskim ludności wielkoruskiej w zasadzie nie ma, zaś rdzenni mieszkańcy to sa Łatgalczycy i Białorusini, podczas gdy Wielkorusi i Polacy stanowia nieliczny element, którego pojawienie się tu jest zwiq̨zane z panowaniem rosyjskim i obecnościa ziemiaństwa polskiego oraz działalnością prawosławnego duchowieństwa wielkoruskiego i części duchowieństwa katolickiego pochodzącego z Polski¹.

Łatgalia była regionem, który posiadał także zwarte skupiska ludności polskiej. Niemniej jednak, Polacy znajdowali się w gorszej sytuacji w porównaniu z ludnością białoruską i rosyjską. W przeciwieństwie do Białorusinów i Rosjan, Polacy byli pozbawieni jakiejkolwiek autonomii szkolnej. W związku z tym część mieszkańców Łatgalii i powiatu iłuksztańskiego, którzy przed wojną podawali narodowość polską, podczas okupacji niemieckiej figurowała jako Białorusini. Komendant posterunku policji w Iłukszcie Peteris Pupolis podawał, że w niektórych miejscowościach przed wojną Polacy stanowili dominującą grupę, podczas gdy po przyjściu Niemców niemalże wszyscy zapisali się jako Białorusini ${ }^{82}$. Należy zaznaczyć, że działacze młodego ruchu białoruskiego negowali istnienie chłopów-Polaków na Łotwie. Przyjmowano założenie, że są to „spolonizowani Białorusini”, którym należy przywrócić prawdziwy charakter narodowy. Zgodnie z tą koncepcją polskość na tych terenach była reprezentowana wyłącznie przez ziemiaństwo i części duchowieństwa katolickiego. W związku z tym działacze białoruscy nie kryli satysfakcji z faktu, że niektórzy Polacy zasilali szeregi szkolnictwa białoruskiego, traktując to jako „powrót” spolonizowanych Białorusinów na łono własnej kultury ${ }^{83}$.

81 BA, R 92/102, S. 85.

82 Э. Екабсонс, Беларусы ў Латвіi, s. 204-205.

83 Oto, w jaki sposób sprawę widział wspomniany wcześniej J. Kraśniewicz: Część Białorusinów, która dotąd uważała się za Polaków, nareszcie uzmysłowiła sobie, że jest Białorusinami i że wcześniej pod różnym wpływem tkwiła w niewiedzy co do swojej prawdziwej narodowości, НАРБ, ф. 458, воп. 1, спр. 32, л. 13 зв.-14. 
Tymczasem problem ten był o wiele bardziej złożony, niż wydawało się to działaczom białoruskim. Faktem jest, że niektórzy rodzice-Polacy zdecydowali się wysłać swoje dzieci do szkół białoruskich. Wszakże nie czynili tego, kierując się pobudkami narodowymi, lecz koniunkturalnymi. Z braku własnych szkół część Polaków była zmuszona posyłać swoje dzieci do szkół obcych. W tym przypadku chodziło o chęć zapewnienia swoim dziecom oświaty. Oprócz tego, jak już wspomniano, wielu łatgalskich katolików miało problem z identyfikacją narodową i podawała różną narodowość w zależności od bieżącej sytuacji politycznej, która w czasie okupacji sprzyjała Białorusinom. Zatem do szkół białoruskich obok świadomych Polaków zgłaszali akces także chłopi, którzy nie byli pewni swojej narodowości. Wiadomo, iż w szkolnictwie białoruskim zatrudniano nauczycieli, którzy w okresie międzywojennym dali się poznać jako Polacy. Działacze białoruscy darzyli ich jednak ograniczonym zaufaniem. Kierownictwo Zrzeszenia Białoruskiego odnosiło się do tej grupy ludzi z podejrzliwością i nieufnością, traktując ich jako zakamuflowaną „agenturę polską”. Dowodem tego może być przykład prof. Bolesława Breżgo, który jako bardzo dobrze wykwalifikowany pedagog był brany pod uwagę przy obsadzeniu stanowiska dyrektora gimnazjum białoruskiego w Indrze. Wkrótce jednak jego kandydatura została odrzucona, ponieważ widziano w nim „agenturę polską"84.

Polityka kadrowa w szkolnictwie białoruskim znajdowała się w rękach okupantów. W szkolnictwie zatrudniano osoby, które ukończyły 2-letnie kursy pedagogiczne ${ }^{85}$. Jak już wspomniano, dyrektorów szkół mianował dyrektor generalny oświaty i kultury na wniosek referenta szkolnictwa białoruskiego. Kandydat musiał się wykazać nieposzlakowaną opinią. W tym celu inspekcja szkolna konsultowała sprawy zatrudnieniowe z komisarzem okręgu, na terenie którego mieszkał kandydat ${ }^{86}$. Starano się przestrzegać zasady niezatrudniania w szkolnictwie osób o wątpliwej reputacji. W szczególności interesowano się działalnością kandydata podczas okupacji sowieckiej. Z drugiej zaś strony podczas narady inspektorów szkolnych w Rydze w 1941 r. wyrażono pogląd, że nie powinno się stosować praktyki niedopuszczania do pracy w szkołach osób będących wykwalifikowanymi pedagogami, ale w okresie okupacji sowieckiej współpracujących z Sowietami ${ }^{87}$.

Przez cały okres swojego istnienia szkolnictwo białoruskie w Łatgalii borykało się z brakiem wykwalifikowanych kadr nauczycielskich. Tempo organizacji szkół

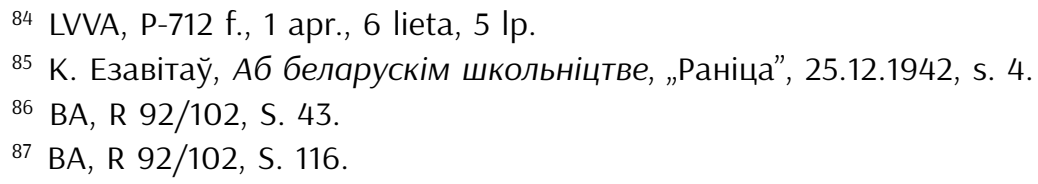


w pierwszych miesiącach okupacji niemieckiej często nie pozwolało na wnikliwą weryfikację umiejętności zawodowych. Problem ten wynikał z faktu, że szkolnictwo białoruskie nie istniało $w$ tym regionie od $1934 \mathrm{r}$. Po inkorporacji Łotwy do ZSRS w 1940 r. część pedagogów przeniesiono do innych republik związkowych, część przeszła na emeryturę lub zmarła ${ }^{88}$. W roku szkolnym 1942/43 w szkolnictwie białoruskim było zatrudnionych tylko 93 nauczycieli (nie licząc katechetów) ${ }^{89}$. Polepszeniu sytuacji miały służyć kursy doskonalenia kwalifikacji zawodowych. W marcu 1942 r. kierownik BKN zwrócił się do szefostwa tej organizacji w Dyneburgu z propozycją zorganizowania kursów dla nauczycieli. W zamyśle miały to być: 1) kursy przygotowania nowych nauczycieli, 2) kursy podniesienia poziomu kwalifikacji dla osób już posiadających pewne kwalifikacje do nauczania w szkołach i 3) kursy języka i kultury białoruskiej dla wszystkich nauczycieli ${ }^{90}$. Kierownictwo Zrzeszenia Białoruskiego wyszło również z inicjatywą utworzenia 4-letniego białoruskiego seminarium nauczycielskiego. Projekt ten nie zyskał jednak uznania władz niemieckich, które zaproponowały utworzenie grupy białoruskiej w seminarium w Rzeżycy ${ }^{91}$. Po raz kolejny uwidoczniły się rozbieżności interesów pomiędzy stronami białoruską a niemiecką. Działacze białoruscy snuli dalekosiężne plany dotyczące rozbudowy własnego szkolnictwa. Tymczasem Niemcy zamierzali tolerować szkolnictwo białoruskie do czasu zakończenia wojny i w związku z tym nie widzieli potrzeby jego dalszej rozbudowy ${ }^{92}$.

Przywódcy ruchu białoruskiego próbowali rozwiązać problem braku kadr nauczycielskich poprzez sprowadzenie pedagogów z Białorusi i Litwy. Na zaproszenie BKN przyjechało kilku nauczycieli, absolwentów Instytutu Pedagogicznego w Witebsku. Byli to ludzie, którzy pochodzili z mieszanych rodzin białorusko-łotewskich. Na początku 1942 r. na łamach prasy białoruskiej ukazującej się w Berlinie i Wilnie pojawiło się ogłoszenie, że szkolnictwo białoruskie w Łatgalii zatrudni nauczycieli ${ }^{93}$. Wbrew oczekiwaniom łotewskich Białorusinów chętnych jednak nie było ${ }^{94}$. Na przeszkodzie stanęły m.in. trudności formalne związane z koniecznością otrzymania od władz niemieckich pozwolenia na zmianę miejsca zamieszkania ${ }^{95}$.

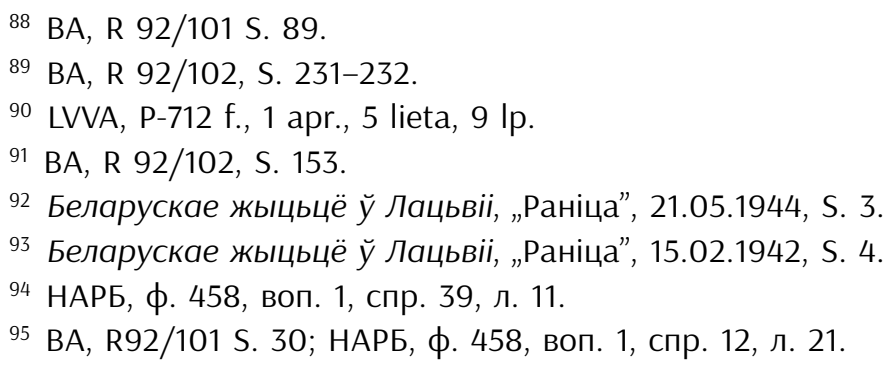


Kierownicy ruchu białoruskiego w Łatgalii wiązali z nauczycielami duże nadzieje na upowszechnienie białoruskiej tożsamości narodowej wśród nieuświadomionych narodowo chłopów. Wymownie dowodzi tego hasło, sformułowane przez prezesa BKN: każdy nauczyciel białoruski to działacz białoruski96. W praktyce jednak nie wszyscy pedagodzy byli w stanie sprostać tej roli. Morale nauczycieli były różne. W pełni wyrobiony narodowo element stanowiła jedynie nieliczna grupka nauczycieli, która rekrutowała się spośród pedagogów i absolwentów przedwojennych gimnazjów białoruskich. Ci ludzie byli pełni zapału i świadomi swoich celów. Natomiast lojalność i patriotyzm pozostałych nauczycieli często budziły uzasadnione zastrzeżenia i wątpliwości czołowych działaczy ruchu białoruskiego. Część nauczycieli wykazywała słabą znajomość języka białoruskiego. Łotewska inspekcja szkolna biła na alarm w związku z tym, że wbrew zarządzeniom władz niemieckich w niektórych szkołach białoruskich lekcje były prowadzone w języku rosyjskim, a nie białoruskim. Tymczasem zajęcia z katechezy dla uczniów-katolików w większości przypadków odbywały się po polsku. W listopadzie 1941 r. K. Jezawitau zwracał uwagę na bierność społeczną większości nauczycieli. Kierownik BKN pisał m.in.:

Nasi nauczyciele są bardzo bierni. Gawędzą, ale robią bardzo niewiele. Brakuje zapału, inicjatywy i zrozumienia sytuacji. Wszyscy czekaja, aż ktoś z góry dlań coś zrobi. Potrzebujemy codziennej pracy. Pracy na rzecz uświadamiania narodowego ${ }^{97}$.

Bardzo krytycznie oceniał wiekszość nauczycieli A. Jakubiecki, kierownik filii Zrzeszenia Białoruskiego w Dyneburgu. Twierdził, że we Iwiej części nauczyciele szkół białoruskich są przesiąknięci obcymi kulturą i wychowaniem. W związku z tym opowiadał się za relegowaniem ich ze szkolnictwa białoruskiego. Inspektor A. Machnouski w pełni podzielał pogląd o niskim stopniu utożsamiania się znacznej części nauczycieli z białoruskimi wartościami narodowymi, lecz brak patriotyzmu i słabą znajomość języka białoruskiego tłumaczył tym, że przez długi czas nie mieli oni styczności z organizacjami białoruskimi i znajdowali się pod obcymi wpływami. Inspektor nie był zwolennikiem żadnych represji wobec tych ludzi z braku możliwości zastąpienia ich bardziej odpowiednimi kandydatami. Jednocześnie postulował on potrzebę intensywnej i długiej pracy z tymi nauczycielami w celu ich uświadomienia narodowego ${ }^{98}$. Z myślą o krzewieniu wśród nauczycieli białoruskiej tożsamości narodowej kierownictwo Zrzeszenia

\footnotetext{
96 LVVA, P-712 f., 1 apr., 6 lieta, 18-19 Ip.

97 LVVA, P-712 f., 1 apr., 6 lieta, 7 lp.

98 LVVA, P-712 f., 1 apr., 5 lieta, 23 Ip.
} 
Białoruskiego kolportowało wśród nich prasę białoruską, która była wydawana w Rydze, Mińsku, Wilnie, Berlinie i Białymstoku. Nauczycielom wysyłano poszczególne numery i zachęcano do prenumerowania i czytania gazet białoruskich. Krzewieniu patriotyzmu miały służyć także przedsięwzięcia kulturalne. W murach szkolnych odbywały się liczne występy, imprezy, koncerty i wystawy. Urządzano także uroczystości z okazji obchodów białoruskich świąt narodowych, podczas których śpiewano pieśni patriotyczne i ludowe. W niektórych szkołach działały uczniowskie chóry i zespoły artystyczne ${ }^{99}$.

Poważnym utrudnieniem w procesie nauczania w szkołach białoruskich był brak podręczników i literatury. W szczególności istniało zapotrzebowanie na podręczniki z gramatyki białoruskiej, historii, geografii, arytmetyki i języka niemieckiego ${ }^{100}$. Często nauczyciele musieli kupować książki za własne pieniądze. Kierownicy szkół zwracali się do zarządu Zrzeszenia Białoruskiego z prośbami o przysłanie książek ${ }^{101}$. Działacze białoruscy musieli zadbać przynajmniej częściowo o zaopatrzenie szkół w niezbędną literaturę. Z inicjatywy kierownika Zrzeszenia Białoruskiego K. Jezawitaua ruszyła akcja zbiórki przedwojennych podręczników. Do wiosny 1942 r. udało się wyposażyć w podręczniki młodsze klasy, podczas gdy w starszych nadal dawał się we znaki ich brak ${ }^{102}$. Rozpoczęto poszukiwania książek poza granicami Łotwy - w Wilnie, Mińsku, Berlinie i Białymstoku. Za sprawą rozległych kontaktów z różnymi ośrodkami inteligencji białoruskiej, które miał K. Jezawitau, udało się pozyskać część podręczników ${ }^{103}$.

Brak podręczników zmusił miejscowych działaczy białoruskich do intensyfikacji prac nad rozpoczęciem działalności wydawniczej. Z inicjatywy K. Jezawitau w połowie 1942 r. wśród nauczycieli ruszyła zbiórka pieniędzy na fundusz wydawniczy. Każdy nauczyciel przekazywał na ten cel jedną wypłatę miesięczną rocznie ${ }^{104}$. W zbiórkę włączył się także inspektorat szkół białoruskich w Łatgalii105. Czasami udawało się zebrać pokaźne kwoty pieniężne ${ }^{106}$. Na owoce nie trzeba było długo czekać i w połowie 1943 r. w nakładzie 3 tys. egzemplarzy wydano wspomniany wcześniej podręcznik autorstwa K. Jezawitaua Szkoła Białoruska

99 НАРБ, ф. 458, воп. 1, спр. 35, л. 21.

100 НАРБ, ф. 458, воп. 1, спр. 35, л. 16.

101 НАРБ, ф. 458, воп. 1, спр. 32, л. 5.

102 Беларускае жыцьцё ў Лацьвіi, „Раніца”, 29.03-5.04.1942, s. 5.

103 НАРБ, ф. 458, воп. 1, спр. 12, л. 8.

104 Ю. Туронак, Беларуская кніга паg нямецкім кантролем, [w:] idem, Мagэрная гісторыя Беларусі, Вільня 2006, s. 342.

105 НАРБ, ф. 458, воп. 1, спр. 16, л. 5.

106 LVVA, P-712 f., 1 apr., 5 lieta, 18 lp. 
(wydanie III). Książka okazała się bardzo pomocna podczas lekcji języka białoruskiego, choć nie była ona pozbawiona wad edytorskich i technicznych. Maszynopis był przygotowywany do druku przez redaktorów łotewskich nieznających języka białoruskiego, co sprawiło, że w wydanej książce roiło się od literówek i błędów ${ }^{107}$. K. Jezawitau zamierzał kontynuować wydawanie podręczników i literatury na potrzeby szkolnictwa białoruskiego na Łotwie. Tym zamiarom nie dane było jednak się spełnić ze względu na brak środków na wydanie ${ }^{108}$.

Warto pamiętać, że nauczanie w szkołach białoruskich działających pod okupacją niemiecką nosiło piętno tamtych czasów. Świadczyły o tym choćby programy nauczania historii i geografii. Zawarto w nich treści zgodne z interesami politycznymi i ideologicznymi III Rzeszy. Podkreślano więzi Białorusinów z Niemcami i kulturą niemiecką. Dużo miejsca poświęcano średniowiecznym związkom ziem białoruskich z Germanami. W szczególności skupiano się na stosunkach handlowych Połocka z Zakonem Inflanckim oraz wpływach niemieckich na kulturę przodków Białorusinów. Jednocześnie w bardzo negatywnym świetle ukazywano inne narody sąsiadujące z Białorusinami: Polaków i Rosjan. W drugiej klasie na lekcjach z historii Białorusi omawiano takie tematy, jak: Walka Białorusinów z polonizacja, Naród białoruski pod jarzmem polskim, Opór wsi białoruskiej przeciwko kolektywizacji, Białoruski ruch narodowy pod polskim i moskiewskim panowaniem, Rozpad Polski i ZSRS, Zwycięska walka narodów Europy z plutokratycznym i komuno-internacjonalistycznym jarzmem. Tymczasem na lekcjach z geografii omawiano m.in. temat Wielkie Niemcy i ich rola w życiu Europy Środkowej ${ }^{109}$.

Większość szkół uporało się z problemami natury materialnej. Z powodu trwającej wojny zdarzało się, że część budynków szkolnych było przejętych przez Wehrmacht. Pięcioklasowa szkoła we wsi Gryve od listopada 1942 r. z powodu braku innych pomieszczeń korzystała z budynku dawnej synagogi w Dyneburgu. Podobnie sytuacja wyglądała w przypadku gimnazjów w Indrze i Zilupe, ponieważ w 1943 r. ich budynki zostały zarekwirowane przez wojsko. Gimnazjum w Indrze najpierw (od lutego 1943 r. do lutego 1944 r.) mieściło się w budynku należącym do miejscowej białoruskiej szkoły podstawowej, a potem w jednym z budynków mieszkalnych. Z kolei nauczyciele i uczniowie gimnazjum w Zulupe w 1943 r. dwukrotnie zmieniali miejsce pobytu ${ }^{110}$. Jesienią 1942 r. w szkole

\footnotetext{
107 LVVA, P-712 f., 1 apr., 4 lieta, 36 lp.

108 Ю. Туронак, Беларуская кніга паg нямецкім кантролем, s. 342-344.

109 BA, R 92/91, S. 15.

110 Э. Екабсонс, Беларусы ў Латвіi, s. 215.
} 
w Pustynie nie rozpoczęto roku szkolnego, ponieważ zabrakło odpowiedniego budynku ${ }^{111}$. Tymczasem uczniowie szkoły we wsi Demene dzielili wspólny budynek z uczniami łotewskimi. Białorusini zajmowali tylko jeden pokój, podczas gdy Łotysze korzystali z czterech. Wyjątkowo trudna sytuacja zaistniała w szkole we wsi Garavaja, gdzie z braku pomieszczeń dyrektor Ignacy Błażewicz musiał mieszkać w kancelarii, która jednocześnie służyła jako noclegownia dla uczniów z odległych wsi ${ }^{112}$. W ciężkim położeniu znalazła się szkoła w Pustynie. Świadczy o tym m.in. list dyrektora tej szkoły Antoniego Kłagisza do prezesa Zrzeszenia Białoruskiego, w którym czytamy m.in.:

gdy nie dostaniemy zgody na lekcje w budynku szkolnym albo $w$ druga zmianę razem z Łotyszami w szkole łotewskiej, to sytuacja Białorusinów będzie bardzo zła. Już teraz Łotysze kpią z nas, że szkoła białoruska może istnieć na prowincji, lecz nie w Pustynie, mówią, że niech oni odpoczną itd. [...]. pomieszczenia, które otrzymaliśmy od dowódcy kompanii nie spełniaja podstawowych warunków, zaś rodzice widząc bezradność Białorusinów powstrzymuja się od wysyłania dzieci do szkoły białoruskiej"13.

Sytuacja uczniów niektórych szkół białoruskich pozostawiała wiele do życzenia - często nie mieli oni obuwia i ubrania, co było przyczyną niskiej frekwencji na lekcjach. Inspektor A. Machnouski obarczał winą za zaistniałą sytuację administrację gminną, która dopuściła się wielu zaniedbańn ${ }^{114}$.

Stan bezpieczeństwa w większości szkół nie budził zastrzeżeń. Niemniej jednak część szkół znajdowała się w strefie zagrożonej przez partyzantkę sowiecką. W roku szkolnym 1942/43 doszło do szeregu napadów partyzantów na te szkoły. Wówczas niektóre z nich nawet przestały istnieć - należące do szkół budynki zostały zniszczone przez napastników ${ }^{115}$. W 1943 r. trzeba było się zmierzyć z nowym problemem. Część uczniów została zmobilizowana do Legionu Łotewskiego SS ${ }^{116}$. Sytuacja była niepomyślna do tego stopnia, że ze względu na niską frekwencje lekcje nie mogły się odbywać. 25 października 1943 r. referent P. Miranowicz alarmował, że mobilizacja uczniów do wojska uniemożliwiła powstanie klas starszych w gimnazjum w Indrze. Znane są przypadki, gdy niektórzy uczniowie i nauczyciele dobrowolnie zaciągali się do Legionu Łotewskiego SS. Przykładem był dyrektor szkoły w Ajzupe Wiktor

111 НАРБ, ф. 458, воп. 1, спр. 15, л. 10.

112 BA, R 92/102, s. 203.

113 НАРБ, ф. 458, воп. 1, спр. 32, л. 9.

114 BA, R 92/102, s. 241.

115 Э. Екабсонс, Беларусы ў Латвіi, S. 215.

116 НАРБ, ф. 458, воп. 1, спр. 35, л. 32 зв. 
Zawisza, który wiosną 1943 r. zgłosił się na ochotnika. Znane są nazwiska niektórych uczniów-Białorusinów, którzy służyli i zginęli na froncie jako żołnierze łotewskich formacji zbrojnych w służbie niemieckiej ${ }^{117}$.

Pomimo wymienionych problemów szkolnictwo białoruskie $w$ Łatgalii nie przestało funkcjonować. Liczba uczniów, którzy ukończyli białoruskie szkoły podstawowe, wahała się pomiędzy 150 a 180 osobami rocznie ${ }^{118}$. Rok szkolny 1943/44 był ostatnim rokiem istnienia szkolnictwa białoruskiego w tym regionie. W wyniku ofensywy wojsk sowieckich latem $1944 \mathrm{r}$. Łatgalia została zajęta przez Armię Czerwoną.

Podsumowując, należy stwierdzić, że pod okupacją niemiecką w Łatgalii nastąpiło ożywienie białoruskiego ruchu narodowego. Paradoksalnie, ale właśnie w warunkach okupacji niemieckiej Białorusini otrzymali możliwość większej działalności kulturalno-oświatowej niż przed wojną. W latach 1941-1944 w Łatgalii działały zespoły teatralne, 35 białoruskich szkół podstawowych i 3 średnie (dwa gimnazja i szkoła rolnicza), w których pracowało około 100 nauczycieli19. Współpracę działaczy białoruskich z Niemcami w zakresie kulturalno-oświatowym trudno jednoznacznie ocenić. Niewątpliwie miejscowi działacze białoruscy kierowali się zimną polityczną kalkulacją i chcieli wykorzystać bieżącą sytuację międzynarodową do osiągnięcia własnego celu, którym było budzenie świadomości narodowej białoruskojęzycznej ludności Łatgalii. Wbrew tym oczekiwaniom ich praca nie przyniosła znaczących rezultatów. W warunkach wojny i okupacji działalność kulturalno-oświatowa napotykała liczne przeszkody. Nie będzie przesadą stwierdzenie, że wówczas położono jedynie podwaliny pod życie narodowe Białorusinów w tym kraju. To, co udało się osiągnąć Białorusinom, a nie było to wiele, i tak zostało zaprzepaszczone po zajęciu tego regionu przez Armię Czerwoną.

117 Э. Екабсонс, Беларусы ў Латвіi, s. 218.

118 Беларускае жыцьцё ў Лацьвіi, „Раніца”, 28.06.1942, s. 3; К. Езавітаў, Аб беларускім школьніцтве, “Раніца”, 25.12.1942, s. 3; Беларускае жыцьцё ў Лацьвіі, „Раніца”, 22.05.1944, s. 3.

119 Беларускае жыцьцё ў Лацьвіi, „Раніца”, 28.02.1942, s. 3. 


\section{Bibliografia}

\section{Źródła archiwalne}

Archiwum Akt Nowych w Warszawie (AAN).

Mikrofilmy aleksandryjskie (sygnatura T-454).

Bundesarchiv, Berlin-Lichterfelde Ost (BA).

Reichsministerium für die besetzten Ostgebiete (sygnatura R6).

Abteilung für Bildung und Kultur des Generalbezirk Lettland (sygnatura R92).

Latvijas Nacionālā arhīva Latvijas Valsts vēstures arhīvs (LVVA).

Biedrïba „Baltkrievu apvienïba” (sygnatura P-712).

Nacyânal'ny arhiǔ Rèspublikì Belarus' (NARB) [Нацыянальны архіў Рэспрублікі Беларусь (НАРБ)].

Ezovitov Konstancin Barysavič (F. 458) [Езавітаў Канстанцін Барысавіч (Ф. 458)]

\section{Opracowania}

Albin J., Polski ruch narodowy na Łotwie w latach 1919-1940, Wrocław 1994.

Apine I., Baltkrievi Latvijā, Rīga 1995.

Eberhardt P., Problematyka narodowościowa Łotwy, „Zeszyty IGiPZ” 1998, nr 54, Warszawa.

Ekabsons È. (Jēkabsons Ė.), Belarusy ǔ Latvii ǔ časy saveckaj i nâmecka-fašysckaj akupacyì (19401945), „Belaruskì Gìstaryčny Aglâd” 2006, t. 13, sš. 2, s. 199-233 [Екабсонс Э. (Jēkabsons Е.), Беларусы ў Латвіi ў часы савецкай і нямецка-фашысцкай акупацыі (1940-1945), „Беларускі Гістарычны Агляд” 2006, т. 13, сш. 2, с. 199-233].

Ekabsons È. (Jēkabsons Ė.), Belorusy v Latvii v 1918-1940 godah, [w:] Belaruskaâ dyâspara âk pasârèdnica ǔ dyâlogu cyvilizacyj. Matèryâly III Mižnarodnaga kangrèsa belarusistaǔ, Minsk 2001, s. 76-93 [Екабсонс Э. (Jēkabsons Ё.), Белорусы в Латвии в 1918-1940 гоgax, [w]: Беларуская gыяспара як пасярэgніца ў gыялогу цывілізацый. Матэрыялы III Міжнароgнага кангрэса беларусістаў, Мінск 2001, 76-93].

Grzybowski J., Zrzeszenie Białoruskie w Okręgu Generalnym Łotwa (1941-1945), „Przegląd Historyczny" 2018, t. 109, z. 1, s. 95-117.

Jēkabsons E.., Białorusini na Łotwie w okresie okupacji hitlerowskiej (1941-1945), „Studia Interkulturowe Europy Środkowo-Wschodniej" 2014, t. 7, s. 13-26.

Jēkabsons Ė., Padomju represijas pret Latvijas poliem, lietuviešiem, un baltkrieviem 1940. 1941. gadā, [w:] Totalitārie režìmi in to represijas Latvijā 1940. - 1956. gada, Rīga 2007, s. $51-70$.

Łossowski P., Kraje bałtyckie na drodze od demokracji parlamentarnej do dyktatury 1918-1934, Wrocław 1972. 
Manteuffel G. Inflanty Polskie oraz Listy znad Bałtyku, Kraków 2009.

Turonak Û., Belaruskaâ kniga pad nâmeckìm kantrolem, [w:] idem, Madèrnaâ gìstoryâ Belarusi, Vil'nâ 2006 [туронак Ю., Беларуская кніга паg нямецкім кантролем, [w:] idem, Маgэрная гісторыя Беларусі, Вільня 2006].

\section{Źródła opublikowane, prasa}

Belaruskae žyc'cë ǔ Lac'viì, „Ranìca” 15.02.1942, s. 4 [Беларускае жыцьцё ў Лацьвіi, „Раніца”, 15.02.1942, c. 4].

Belaruskae žyc'cë ǔ Lac'vì̀, „Ranìca”, 29.03.1942, s. 5 [Беларускае жыцьцё ў Лацьвіi, „Раніца”, 29.03.1942, с. 5].

Belaruskae žyc'cë ǔ Lac'viì, „Ranìca”, 28.06.1942, s. 3 [Беларускае жыцьцё ў Лацьвіi, „Раніца”, 28.06.1942, с. 3].

Belaruskae žyc'cë ǔ Lac'vì, „Ranìca”, 21.05.1944, s. 3 [Беларускае жыцьцё ў Лацьвіi, „Раніца”, 21.05.1944, c. 3].

Belarusy ǔ Latviì, „Ranìca”, 20.11.1941, s. 3 [Беларусы ў Латвіi, „Раніца”, 20.11.1941, с. 3].

Ezavitaǔ K., Ab belaruskim škol'nictve, „Ranica”, 25.12.1942, s. 3-4 [Езавітаў K., Аб беларускім школьніцтве, „Раніца”, 25.12.1942, с. 3-4]. 
CZĘŚĆ II

KULTUROWE WYZWANIA TOŻSAMOŚCI BIAŁORUSKIEJ 


\section{Дзейнасць Беларускага інстытуту навукі і мастацтва (Нью-Ёрк) па захаванні і пашырэнні беларускай нацыянальнай ідэнтычнасці}

Activities of the Belarusian Institute of Arts and Sciences (New York) to preserve and expand the Belarusian national identity

After the Second World War, emigrants from Belarus who found themselves in the West had very different levels of national self-consciousness. United by a common origin and memory, they nevertheless faced a real threat of disappearing in the host societies without leaving a trace. However, representatives of the national intellectuals took care of preserving and expanding the Belarusian national identity among Belarusian emigrants. Founded in 1951 in New York, the Belarusian Institute of Arts and Sciences has become a flagship in this field. Over the decades, through its cultural, educational and publishing initiatives, it has been spreading information about Belarus, its history and culture to the masses of emigrants, contributing in many ways to the preservation and expansion of Belarusian identity not only among emigrants, but also in Belarus. Keyw ord s: Belarusian Institute of Arts and Sciences, national identity, Belarusian emigration

Działania Białoruskiego Instytutu Sztuki i Nauki (Nowy Jork) na rzecz zachowania i rozwoju białoruskiej tożsamości narodowej

Po II wojnie światowej na Zachodzie znaleźli się emigranci z Białorusi o bardzo różnym poziomie samoświadomości narodowej. Zjednoczeni wspólnym pochodzeniem i pamięcią, stawali niemniej przed realnym niebezpieczeństwem rozpłynięcia się bez śladu w społeczeństwach przyjmujących. Jednakże przedstawiciele intelektualistów narodowych zadbali o zachowanie i rozszerzenie białoruskiej tożsamości narodowej wśród białoruskich emigrantów. Założony w 1951 r. w Nowym Jorku Białoruski Instytut Nauki i Sztuki stał się wizytówką tej działalności. Przez dziesięciolecia, poprzez swoje inicjatywy kulturalne, edukacyjne i wydawnicze, Instytut rozpowszechniał informacje o Białorusi, jej historii i kulturze wśród rzesz emigrantów, przyczyniając się na wiele sposobów do zachowania i rozwoju białoruskiej tożsamości nie tylko wśród emigrantów, lecz także mieszkańców Białorusi.

Sło wa k l u c z o we: Białoruski Instytut Nauki i Sztuki, tożsamość narodowa, emigracja białoruska 
Пасля Другой сусветнай вайны на Захадзе апынулася больш за сто тысяч беларусаў, якія раз'ехаліся па розных краінах Еўропы, Амерыкі, Аўстраліі. Нягледзячы на тое, што была гэта менавіта палітычная эміграцыя, якая аб'ядноўвала суродзічаў у іх нежаданні жыць “пад Саветамі", нацыянальная самасвядомасць тых эмігрантаў была вельмі розная. Дзеля найперш патрэб выжывання яны запісваліся палякамі, украінцамі, літоўцамі, латышамі, дый рэальнае ўсведамленне сваёй нацыянальнай прыналежнасці ў паваенных эмігрантаў было неаднастайнае. Сярод тых уцекачоў былі дзясяткі тысяч беларусаў, у якіх рэлігійная ідэнтычнасць пераважала над нацыянальнай, і таму каталікі зусім спакойна дазвалялі сябе залічваць (або і самі лічылі) палякамі, а праваслаўныя - расейцамі. Была ў шэрагах паваенных эмігрантаў і шматлікая моладзь, што прайшла праз польскія ці савецкія школы, або яшчэ не прайшла ні праз якія, і яе лёгка было страціць.

Аднак важна, што сярод беларусаў, якія апынуліся на Захадзе пасля Другой сусветнай вайны, была і адметная колькасць інтэлігенцыі настаўнікаў, пісьменнікаў, мастакоў, музыкаў, медыкаў, інжынераў. Менавіта яны і ўзялі на сябе місію па "ўсведамленні" суродзічаў-эмігрантаў: сталі ствараць нацыянальныя арганізацыі, ладзіць імпрэзы, выдаваць перыёдыку і кнігі. Са старонак газет ішлі рэгулярныя напаміны пра неабходнасць захавання нацыянальнай самасвядомасці. Прыкладам, як у артыкуле Станіслава Станкевіча У новых краёх - новыя заgаньні:

Кажны спасярод апошніх (выгнанцаў - Н. Г.) павінен глыбака ўсьведаміць сабе, што найвялікшым ягоным абавязкам на чужыне ёсьць захаваньне таго найдаражэйшага скарбу, які ён вынес із сваёй роднай хаты на Бацькаўшчыне - сваёй беларускай нацыянальнасьці'.

3 часам высілкі ў захаванні нацыянальнай беларускай ідэнтычнасці сталі распаўсюджвацца не толькі на тых, хто выехаў з Беларусі ў часе вайны, але і на эмігрантаў міжваеннага часу, тысячы якіх жылі ў розных краінах і пераважна не вызначаліся нацыянальнай свядомасцю, а таксама на народжаных ужо на чужыне дзяцей эмігрантаў.

Задача захавання і пашырэння беларускай нацыянальнай самасвядомасці была задачай інтэлігенцыі на эміграцыі. Але для яе рэалізацыі патрэбныя былі адмысловыя структуры, адной з якіх стаў заснаваны ў 1951 годзе Беларускі інстытут навукі і мастацтва. Галоўнай мэтай ягонага стварэння

1 С. Станкевіч, У новых краёх - новыя заgаньні, “Бацькаўшчына", 1.06.1949, № 13 (57), c. 1-2. 
было "гуртаваньне працаўнікоў беларускае навукі, літаратуры й мастацтва за межамі Беларусі дзеля падтрыманьня, ажыўленьня й каардынаваньня беларускае культурна-навуковае працы на эміграцыі"2. Фактычна БІНіМ ствараў магчымасці для працы пісьменнікаў, мастакоў, навукоўцаў і г.д., праз вынікі дзейнасці якіх і ішло захаванне і пашырэнне беларускай нацыянальнай ідэнтычнасці. Ужо на працягу першага года працы ў Інстытуце было звыш 50 сябраў, у сярэдзіне 1960-х - больш за 70 з васьмі краін светуз3.

Найперш нацыянальная праца БІНіМу была скіравана на суродзічаўэмігрантаў і ажыццяўлялася ў розных формах, напрыклад, у ладжанні навукова-папулярных імпрэз - вечароў паэзіі і рэфератаў з галіны беларусаведы. Вось прыклад тых мерапрыемстваў, якія былі арганізаваны Інстытутам на працягу 1955 года:

Зборкі новага, 1955 г. сэзону пачаліся 5 лютага дакладам Вітаўта Тумаша "Найнавейшыя пагляды пра паходжаньне беларускага аканьня".

Потым былі адчытаныя такія спавешчаньні:

19.02 - дыскусія над прачытаным аўтаркаю, Аляксандрай Саковіч, новым апавяданьнем;

23.04 - Антон Адамовіч, "Саветызацыя беларускае літаратуры";

07.05 - дыскусійнае паседжаньне над зборнікамі вершаў: Міхась Кавыль, "Пад зорамі белымі"; Янка Юхнавец, "Шорах моўкнасьці"; Масей Сяднёў, “Ля ціхай брамы”. Рэфэрэнт - Антон Адамовіч;

21.05 - Вітаўт Тумаш, "Заходнія элемэнты культуры Беларусі";

04.06 - дыскусійнае паседжаньне аб некаторых цікавых, рэдка ужжываных словах беларускае народнае мовы. Рэфэрэнты - Вітаўт Тумаш і Антон Адамовіч;

17.11 - справаздача віцэ-старшыні Антона Адамовіча з падарожжа ў Эўропу на навуковую канфэрэнцыю і асамблею Інстытуту вывучэньня СССР;

15.10 - Язэп Гладкі, "Успаміны аб Усебеларускім Кангрэсе ў Менску ў 1917 г.";

03.12 - Вітаўт Тумаш, "Беларускія элемэнты ў творчасьці Адама Міцкевіча";

17.12 - Антон Адамовіч, "Некаторыя цікавыя словы із слоўнікаў Лаўрэнція Зызанія й Памвы Бярынды”.

Дзесяць мерапрыемстваў цягам года на тэмы гісторыі, мовы, літаратуры, сучасных падзей на эміграцыі. 3 рознай інтэнсіўнасцю гэткія імпрэзы, а пазней і прэзентацыі кніг ладзіліся БІНіМам у Нью-Ёрку амаль да канца XX стагоддзя. Сярод выступоўцаў былі беларусы не толькі Нью-Ёрка

2 Ag рэлакцыі й выgавецтва, “Запісы БІнІМ” 1952, № 1, с. 1.

3 Н. Гардзіенка, Л. Юрэвіч, Хронікі БІніму. Гісторыя Беларускага інстытуту навукі і мастацтва у дакументах, лістах і ўспамінах, Мінск 2017, с. 92.

4 Ibidem, c. $77-78$. 
і Нью-Джэрсі, але і іншых беларускіх асяродкаў ЗшА, Канады, Францыі, Вялікабрытаніі, Аўстраліі і іншых, а з 1990-х - і Беларусі. Пазней імпрэзы перараслі пераважна ў кніжныя прэзентацыі і сталі ладзіцца таксама у Беларусі (у апошнія гады найчасцей у супрацоўніцтве са Згуртаваннем беларусаў свету “Бацькаўшчына”).

Акрамя згаданых лакальных мерапрыемстваў БІніМ ладзіў навуковыя канферэнцыі. Адну з найбуйнейшых адбылася з нагоды 25-х угодкаў дзейнасці Інстытуту ў 1977 годзе ва ўніверсітэце Сэтан-Хол (Нью-Джэрсі). 3 дакладамі ў ёй выступалі не толькі ўласна беларускія навукоўцы: Вітаўт Тумаш, Івонка Сурвіла, Янка Запруднік, Янка Садоўскі, Антон Адамовіч, Вольга Арэхва, Станіслаў Станкевіч, Раіса Жук-Грышкевіч, Галіна Русак, Уладзімір Шыманец, Дзмітрый Верасаў, Уладзімір Брылеўскі, Васіль Мельяновіч, Вітаўт Кіпель, але і даследчыкі іншых нацыянальнасцей: Патрыцыя Кенэдзі-Грымстэд, Юры Шавялёў, Томас Бэрд.

Яшчэ адной формай пашырэння беларускай нацыянальнай самасвядомасці сталі ладжаныя БІНіМам мастацкія выставы. Першая экспазіцыя беларускіх мастакоў была арганізавана Інстытутам у снежні 1972 - лютым 1973 года, другая - у лістападзе - снежні 1976 года. 3 часам выставы сталі рэгулярнымі, для ўдзелу ў іх запрашаліся мастакі, якія жылі не толькі ў ЗшА, але і ў Канадзе, Францыі, Бельгіi і іншых краінах 5 .

БІНіМам і яго сябрамі ладзіліся выставы не толькі мастацкія, але і кніжныя. Адной з найбольш важных была выстава, прысвечаная 450-годдзю беларускага кнігадрукавання, арганізаваная ў Нью-Ёркскай публічнай бібліятэцы ў сакавіку - ліпені 1968 года.

Разьмешчаная была выстаўка ў прасторнай галярэі другога паверху бібліятэкі. Экспанавала яна больш 200 кнігаў, брашураў, часапісаў, партрэтаў, абразоў, картаў, гравюраў, фатарэпрадукцыяў беларускіх старадрукаў ды графічных іх аздобаў. Апрача трынаццаці вялікіх выставовых сталоў-вітрынаў, экспанаты, - найперш апраўленыя ў рамы пад шклом партрэты ды абразы, - займалі й сьцены галярэі. Усе вітрыны выстаўкі мелі свае паясьняльныя, у ангельскай мове, даведкі, а ўсе экспанаты - бібліяграфічныя анатацыіб.

Выставу наведалі тысячы чалавек (не толькі беларусы і іх нашчадкі), і яна мела вялікі розгалас. Заўважаная яна была і нядобразычліўцамі беларусаў. Вось, што пісаў у адным з лістоў з таго часу дырэктар БІНіМу Вітаўт Тумаш:

5 Ibidem, c. 131.

${ }^{6}$ В. Зубкоўскі, Выстаўка Публічнай Бібліятэкі ў Ню Ёрку, “Запісы БІНіМ” 1970, № 5, c. 124. 
Ад мінулага тыдня была наканец паведзеная вострая атака на выстаўку з боку старое расейскае чорнае сотні. Адным часам на рукі дырэктара было накіравана ці не паўтузіна лістоў з розных канцоў Нью Ёрку, тэма якіх адна (з чаго відаць, што акцыя арганізаваная), што выстаўка наладжаная "русафобамі", бо на інфармацыйнай картцы на 6-м стале гаворыцца пра нейкую "русыфікацыю" беларускай мовы за часоў царскіх, чаго ніколі ня было й не магло быць, бо як-жа можна русыфікаваць адзін з дыялектаў рускае якраз мовы!!!?

Аднак ці не найбольш важнай і эфектыўнай формай працы БІніМу у галіне пашырэння нацыянальнай ідэнтычнасці ад самага пачатку была выдавецкая дзейнасць. Інстытут уласна і паўстаў з жадання мець менавіта беларускі навуковы часопіс. Ад 1952 года пачалі выходзіць “Запісы БІНіМ”, на старонках якіх маглі змяшчаць свае даследаванні, зацемкі, рэцэнзіі як уласна беларускія навукоўцы, гэтак і даследчыкі іншых нацыянальнасцей. Тут публікаваліся матэрыялы па гісторыі беларускай музыкі, мастацтва, тэатра, літаратуры, мовы, водгукі на разнастайныя беларусазнаўчыя выданні навукоўцаў з розных краін, у тым ліку і БССР.

Першапачаткова альманах выходзіў некалькі разоў на год, потым былі пэўныя перапынкі ў выданні, звязаныя з праблемамі фінансаў і арганізацыі друку. Ад пачатку XXI стагоддзя “Запісы БІніМ” сталі сумесным ньюёркска-менскім праектам і выдаюцца больш-менш рэгулярна як гадавік. На працягу гісторыі гэтага альманаха змянілася яго канцэпцыя: ад агульнага беларусаведнага ён ператварыўся сёння ў выданне, прысвечанае гісторыі і культуры самой беларускай эміграцыі, папулярызуючы і аналізуючы яе даробак. Гэтым Інстытут намагаецца спрыяць працэсам усведамлення існавання агульнай беларускай нацыі з супольнай культурнай спадчынай, створанай як у Беларусі, гэтак і за яе межамі.

Акрамя "Запісаў” БІніМ выдаваў таксама літаратурны часопіс "Конадні". На старонках сямі нумароў, якія пабачылі свет у 1954-1963 гадах, друкаваліся паэтычныя, празаічныя, драматычныя творы беларускіх аўтараў, пераклады, рэпрадукцыі мастацкіх прац, літаратурна-крытычныя артыкулы. Усё гэта дазваляла пашыраць беларускую мастацкую літаратуру як у эміграцыйных колах, гэтак і ў асяроддзі даследчыкаў іншых нацыянальнасцей.

БІнім займаўся і выданнем кніг. Ад 1950-х гадоў сіламі Інстытуту ўкладаліся і выдаваліся зборнікі беларускіх класікаў - гэтых кніг асабліва бракавала ў эміграцыйным асяроддзі ад самага пачатку жыцця на чужыне. Найбольш важным БІНіМаўскім выдавецкім праектам таго часу стаў больш як

\footnotetext{
7 Цыт. паводле: Н. Гардзіенка, л. Юрэвіч, Хронікі БІніМу, с. 111.
} 
на 550 старонак збор выбраных твораў Янкі Купалы Спаgчына, які пабачыў свет у Мюнхене у 1955 годзе . Гэтае манументальнае выданне мела на мэце захаваць і паказаць суродзічам і ў замежжы, і ў Беларусі (куды асобнікі эміграцыйных выданняў хоць і ў абмежаванай колькасці, але траплялі) нецэнзураваную творчасць беларускага класіка. Акрамя Спаgчыны сябры БІніМу забяспечылі выданне твораў Максіма Багдановіча, Лукаша Калюгі, Якуба Коласа, Андрэя Мрыя і шмат якіх іншых беларускіх літаратараў. Гэтыя кнігі разыходзіліся па беларускіх асяродках, выкарыстоўваліся ў культурнаасветнай працы, у тым ліку і з моладдзю.

У адной са справаздач аб дзейнасці Інстытуту Вітаўт Тумаш адзначаў:

Выданьні Інстытуту - бясспрэчна паважны, бадай найпаважнейшы ўклад у галіне ўсяго навукова-літаратурнага друку беларускае эміграцыі, і яны застануцца трывалымі дасягненьнямі ў гісторыі беларускае культуры й навукі. Маюць яны, зразумела, куды шырэйшы, ня толькі беларускі, круг пашырэньня і ўзьдзеяньня, яны - пазыцыі міжнароднае цікавасьці й значэньня. Іх адзначаюць, іх цытуюць, рэцэнзуюць і крытыкуюць розныя іншамоўныя выданьні Амэрыкі, Эўропы, Эўразіі, значыцца СССР, а навет і Азіі. Яны знаходзяцца ў галоўных бібліятэках усіх кантынэнтаў сьвету.

Што да выданьняў Інстытуту важна яшчэ падчыркнуць, што Ўправа строга сачыла за тым, каб выдаваліся творы й працы агульна беларускае трывалае вартасьці ${ }^{9}$.

3 часам і, у пэўным сэнсе, з насычэннем эміграцыйнага спажывецкага рынку творамі беларускай класікі БІНіМ узяў на сябе клопат выдання твораў пісьменнікаў-выгнанцаў. Так пры канцы 1970-х гадоў была запачаткавана адмысловая кніжная серыя "Беларускія паэты й пісьменнікі”», у якой цягам чатырох дзесяцігоддзяў пабачылі свет зборнікі Наталлі Арсенневай, Алеся Салаўя, Аляксандры Саковіч, Міхася Кавыля, Уладзіміра Дудзіцкага, Лявона Савёнка, Юркі Віцьбіча, Янкі Юхнаўца ${ }^{10}$. Гэтымі выданнямі Інстытут зрабіў бачнай творчасць аўтараў-эмігрантаў суродзічам не толькі на Захадзе, але і ў метраполіі.

Адметнай з'явай стала і “бібліяграфічная” серыя выданняў БІНіМу. Безумоўнымі яе ініцыятарамі і рухавікамі былі супрацоўнікі Нью-Ёркскай

8 Больш пра падрыхтоўку гэтага выдання гл.: Як выgaвалі “Спаgчыну”. Да 135-гоggзя ag нараgжэння і 75-гоggзя смерці Янкі Купалы, укл. Н. Гардзіенка, Л. Юрэвіч, Мінск 2018, 290 с.

9 Цыт паводле: Н. Гардзіенка, Л. Юрэвіч, Хронікі БІніМу, с. 96-97.

10 Ibidem, c. 133-136. 
публічнай бібліятэкі Вітаўт і Зора Кіпелі, якія ў 1985 годзе выдалі яе першую кнігу - Янка Купала і Якуб Колас на Захаgзе ${ }^{11}$. Пазней выйшлі Пяць стагоgзьgзяў Скарыніяны Вітаўта Тумаша'2, Беларускі і беларусавеgны gрук на Захаgзе тых жа Кіпеляў (некалькі выданняўㄱ), Беларускія слоўнікі й энцыкляпэgы ${ }^{14}$. Кожная з гэтых бібліяграфій з'яўляецца выдатным ключом для даследчыкаў розных галін беларусаведы.

Але на некалькіх выданнях з гэтай серыі варта спыніцца асобна. Ужо у 1970-х гадах стала відавочна, што: па-першае, вырасла новае англамоўнае пакаленне беларусаў (дзяцей беларускіх эмігрантаў), якім варта падаваць беларусазнаўчую інфармацыю па-англійску, а па-другое, дзякуючы дзейнасці беларускіх навукоўцаў, і ў заходніх англамоўных колах з'явіўся запыт на беларусаведную інфармацыю на англійскай мове. У выніку БІНіМ не толькі далучыўся да падтрымкі выдання падручніка беларускай мовы для англамоўных Валянціны Пашкевіч ды падрыхтоўкі ёй англійска-беларускага слоўніка, але і ініцыяваў менавіта англамоўныя навуковыя выданні (сярод іх і англамоўныя “Запісы БІНіМ”). у 1980 годзе пабачыла свет падрыхтаванае сябрамі Інстытуту Янкам Запруднікам і Томасам Бэрдам двухмоўнае выданне тэкстаў "Мужыцкай праўды” і Лістоў з-паg шыбеніцы 15 . А Вітаўт і Зора Кіпелі да ўгодкаў БНР узяліся ўкласці своеасаблівую англамоўную хрэстаматыю і бібліяграфію да гісторыі беларускай дзяржаўнасці. У выніку ў 1988 годзе выйшла новая кніга у “Бібліяграфічнай серыі" БІНіMy Byelorussian Statehood"1 . Гэта своеасаблівая “базавая" чытанка для англамоўнай асобы, зацікаўленай у вывучэнні гісторыі Беларусі XX стагоддзя, з перакладамі тэкстаў Антона Луцкевіча, Аляксандра Цвікевіча, Васіля Захаркі, Мітрафана Доўнар-Запольскага, Пётры Крэчэўскага, Кастуся Езавітава, Язэпа Варонкі

11 Янка Купала й Якуб Колас на Захаgзе, Нью Ёрк 1985, 350 с.

12 Пяць стагоgзьязяў Скарыніяны, Нью Ёрк 1989, XXVIII+283 с.

13 Беларускі й беларусавеgны gрук на Захаgзе. Асобныя выgаньні. Бібліяграфія, Нью Ёрк - Менск 2003, XXII+582 с.; Belarusian Publishing in the West. A Bibliography - Periodicals = Беларускі й беларусавеgны gрук на Захаgзе. Бібліяграфія - Часапісы, газэты, New York 2004, XX+152 c.; V. Kipel, Z. Kipel, Belarusian Publishing in the West. A Bibliography, New York - Warsaw 2006, XVI+841 c.

14 Беларускія слоўнікі й энцыкляпэgыі, Нью Ёрк - Менск 2002, XXXIII+570 с.

15 я. Запруднік, Т.Э. Бэрд, Паўстаньне на Беларусі 1863 гоgy. "Мужыцкая Праўga" й “Лісты з-паg шыбеніцы" = The 1863 Uprising in Byelorussia: "Peasants Truth" and "Letters from beneath the Gallows" (Дакумэнты Беларускай гісторыi = Documents of Byelorussian History), Нью Ёрк 1980, 68 с.

${ }^{16}$ Byelorussian Statehood, New York 1988, 398 c. 
і іншых. Гэтае выданне рабіла беларускую дзяржаўнасць больш блізкаю і зразумелаю для замежнікаў.

У працяг тэмы беларускай дзяржаўнасці, яе гісторыі пабачыла свет і яшчэ адно выданне "Бібліяграфічнай серыі" - дзве кнігі першага тома Архівау Беларускай Нароgнай Рэспублікі, падрыхтаваных Сяргеем Шупам на замову Інстытуту ${ }^{17}$. Гэтая праца стала значнай з'явай у беларускай гістарыяграфіi і самой Беларусі, асновай для напісання сотняў публікацый па гісторыі БНР, праз якія веды пра беларускую дзяржаўнасць ішлі ў масы беларусаў, пашыраючы і паглыбляючы нацыянальную ідэнтычнасць. Праз дзесяцігоддзе працягнулі тэму тры тамы Рagы БНР Наталлі Гардзіенкі і Лявона Юрэвіча, прысвечаныя дзейнасці гэтай структуры на эміграцыі ў паваенны час ${ }^{18}$. Яны выйшлі, праўда, у трэцяй кніжнай серыі БІНіМу - "Гісторыя эміграцыі", у якой таксама выдаваліся працы па гісторыі Беларускай гімназіі імя Янкі Купалы ў Нямеччыне ${ }^{19}$ і знакамітай групы моладзі Дванаццатка ${ }^{20}$, газет "Бацькаўшчына" і “Беларус"21 і студэнцтва на чужыне22, Беларускага кангрэсавага камітэта ${ }^{23}$ і БцР24, Беларуска-Амерыканскага задзіночання ${ }^{25}$ і ўласна беларускай прысутнасці ў ЗшА 26 і яшчэ з дзясятак розных кніг, прысвечаных дзейнасці суродзічаў на Захадзе.

17 Архівы Беларускай Нароgнай Рэспублікі, Вільня - Нью Ёрк - Менск - Прага 1998, т. 1, кн. 1-2, 1721 с.

18 Н. Гардзіенка, Л. Юрэвіч, Paga БНР (1947-1970). Паgзеі. Дакументы. Асобы, Мінск 2013, 648 с.; eadem, idem, Paga БНР (1970-1982). Паgзеі і gакументы, Мінск 2014, 300 с.; eadem, idem, Paga БНР (1982-1997). Паgзеі. Дакументы. Асобы, Мінск 2015, 224 с.

19 Я. Максімюк, Беларуская гімназія імя Янкі Купалы ў Захоgняй Нямеччыне (1945-1950), Нью Ёрк - Беласток 1994, 196 с.

20 я. Запруднік, Дванаццатка. Дакумэнтальная аповесьць пра дванаццацёх беларускіх хлапцоў у Нямеччыне, Вялікабрытаніі й Бэльгіi (1946-1954 г2.), Нью Ёрк 2002, 510 с.

21 Л. Юрэвіч, Летапісны звоg сусьвету Чалавека Сьвеgамага. Гісторыя газэтаў “Бацькаўшчына" й “Беларус" (1947-2000), Менск 2006, 256 с.

22 Б. Рагуля, Беларускае студэнцтва на чужыне, 2-е выд., выпраўленае і дапоўненае, Менск 2006, 188 с.

23 А. Гардзіенка, Беларускі Кангрэсавы Камітэт Амэрыкі (БККА), Смаленск 2009, 428 с.

24 А. Гардзіенка, Беларуская Цэнтральная Paga (БЦР). Стварэнне - gзейнасць заняпаg (1943-1995), Мінск 2016, 480 с.

25 3. Саўка, Беларуская цывілізацыя ў Амэрыцы. Пяцьgзясят гаgоў БеларускаАмэрыканскага Заgзіночаньня 1949-1999. Паgзеі. Дакумэнты. Успаміны. Пэрсаналіі, Мінск 2019, 604 с.

26 В. Кіпель, Беларусы ў ЗшА, 3-е выд., Мінск 2020, 656 с. 
Цягам 70 гадоў сваёй працы Беларускі інстытут навукі і мастацтва дзейнічаў у розных кірунках: арганізаваў сотні мерапрыемстваў, выдаў дзясяткі назваў кніг, сотні беларусаведных артыкулаў на розных мовах, маркі, паштоўкі, улёткі, зладзіў дзясяткі выстаў. Агучанае ў гэтым дакладзе толькі невялікая частка БІНіМаўскіх праектаў. Дзейнасць Інстытуту, скіраваная першапачаткова на суродзічаў-эмігрантаў, з часам (асабліва ад пачатку 1990-х) стала аказваць уплыў і на беларусаў у метраполіі. I сёння яна кіруецца ў абодва бакі дзеля разумення неабходнасці і актуальнасці захавання і пашырэння нацыянальнай ідэнтычнасці як у замежжы, гэтак і ў самой Беларусі.

\section{Бібліяграфія}

Ag рэgакцыі й выgавецтва, "Запісы БІНІМ" 1952, № 1, с. 1 [Ad rèdakcyì j vydavectva, "Zapisy BìnìM" 1952, № 1, s. 1].

Архівы Беларускай Нароgнай Рэспублікі, Вільня - Нью Ёрк - Менск - Прага 1998, т. 1, KH. 1-2, 1721 c. [Arhivy Belaruskaj Narodnaj Rèspublikì, Vil'nâ - N'û Ërk - Mensk - Praga 1998, t. 1, kn. 1-2, 1721 s.].

Беларускі й беларусавеgны gрук на Захаgзе. Асобныя выgаньні. Бібліяграфія, Нью

Ёрк - Менск 2003, XXII+582 c. [Belaruskì j belarusavedny druk na Zahadze. Asobnyâ vydan'nì. Bibliâgrafiâ, N'û Ërk - Mensk 2003, XXII+582 s.].

Беларускія слоўнікі й энцыкляпэgыі, Нью Ёрк - Менск 2002, XXXIII+570 с. [Belaruskiâ sloǔniki j èncyklâpèdyì, N'û Ërk - Mensk 2002, XXXIII+570 s.].

Гардзіенка А., Беларуская Цэнтральная Paga (БЦР). Стварэнне - gзейнасць - заняпаg (1943-1995), Мінск 2016, 480 c. [Gardzienka A., Belaruskaâ Cèntral'naâ Rada (BCR). Stvarènne - dzejnasc' - zanâpad (1943-1995), Mìnsk 2016, 480 s.].

Гардзіенка А., Беларускі Кангрэсавы Камітэт Амэрыкі (БККА), Смаленск 2009, 428 с.

[Gardzìnka A., Belaruskì Kangrèsavy Kamitèt Amèrykì (BKKA), Smalensk 2009, 428 s.].

Гардзіенка Н., Юрэвіч Л., Рaga БНР (1947-1970). Паgзеі. Дакументы. Асобы, Мінск 2013, 648 c. [Gardzienka N., Ûrèvič L., Rada BNR (1947-1970). Padzeì. Dakumenty. Asoby, Mìnsk 2013, 648 s.].

Гардзіенка Н., Юрэвіч Л., Рaga БНР (1970-1982). Паgзеі і gакументы, Мінск 2014, 300 с. [Gardzienka N., Ûrèvič L., Rada BNR (1970-1982). Padzeì ì dakumenty, Mìnsk 2014, 300 s.].

Гардзіенка Н., Юрэвіч Л., Рaga БНР (1982-1997). Паgзеі. Дакументы. Асобы, Мінск 2015, 224 c. [Gardzìnka N., Ûrèvič L., Rada BNR (1982-1997). Padzeì. Dakumenty. Asoby, Mìnsk 2015, 224 s.].

Гардзіенка Н., Юрэвіч Л., Хронікі БІніму. Гісторыя Беларускага інстытуту навукі і мастацтва у дакументах, лістах і ўспамінах, Мінск 2017 [Gardzienka N., Ûrèvič L., 
Hroniki BìNiMu. Gìstoryâ Belaruskaga ìnstytutu navuki ì mastactva ǔ dakumentah, listah ì ǔspaminah, Mìnsk 2017].

Запруднік Я., Дванаццатка. Дакумэнтальная аповесьць пра gванаццацёх беларускіх хлапцоў у Нямеччыне, Вялікабрытаніі й Бэльгіi (1946-1954 г2.), Нью Ёрк 2002, 510 с. [Zaprudnìk Â., Dvanaccatka. Dakumèntal'naâ apoves'c' pra dvanaccacëh belaruskih hlapcoǔ u Nâmeččyne, Vâlikabrytaniì j Bèl'gì (1946-1954 gg.), N'û Ërk 2002, 510 s.].

Запруднік Я., Бэрд Т.Э., Паўстаньне на Беларусі 1863 гоgу. “Мужыцкая Праўgа” й “Лісты з-паg шыбеніцы" = The 1863 Uprising in Byelorussia. "Peasants Truth" and "Letters from beneath the Gallows" (Дакумэнты Беларускай гісторыі = Documents of Byelorussian History), Нью Ёрк 1980, 68 с. [Zaprudnìk Â., Bèrd T.È., Paǔstan'ne na Belarusi 1863 godu: "Mužyckaâ Praǔda" j "Listy z-pad šybenicy" = The 1863 Uprising in Byelorussia: "Peasants Truth" and "Letters from beneath the Gallows" (Dakumènty Belaruskaj gistoryì = Documents of Byelorussian History), N'û Ërk 1980, 68 s.].

Зубкоўскі В., Выстаўка Публічнай Бібліятэкі ў Ню Ёрку, “Запісы БІНіМ” 1970, № 5, с. 124 [Zubkoǔskì V., Vystaǔka Publičnaj Bibliâtèkì ǔ Nû Ërku, "Zapìsy BìNìM" 1970, № 5, s. 124]. Кіпель В., Беларусы ў ЗША, выд. 3, Мінск 2020, 656 с. [Kìpel' v., Belarusy ǔ ZŠA, vyd. 3, Mìnsk 2020, 656 s.].

Максімюк Я., Беларуская гімназія імя Янкі Купалы ў Захоgняй Нямеччыне (1945-1950), Нью Ёрк - Беласток 1994, 196 с. [Maksimûk Â., Belaruskaâ gìmnaziâ ìmâ Ânkì Kupaly ǔ Zahodnâj Nâmeččyne (1945-1950), N'û Ërk - Belastok 1994, 196 s.].

Пяць стагоgзьgзяў Скарыніяны, Нью Ёрк 1989, XXVIII+283 с. [Pâc' stagodz'dzâǔ Skaryniâny, N'û Ërk 1989, XXVIII+283 s.].

Рагуля Б., Беларускае стуgэнцтва на чужыне, выд. 2-е, выпраўленае і дапоўненае, Менск 2006, 188 с. [Ragulâ B., Belaruskae studènctva na čužyne, vyd. 2-e, vypraǔlenae ì dapoǔnenae, Mensk 2006, 188 s.].

Саўка 3., Беларуская цывілізацыя ў Амэрыцы. Пяцьgзясят гаgоў Беларуска-Амэрыканскага Заgзіночаньня 1949-1999. Паgзеі. Дакумэнты. Успаміны. Пэрсаналіі, Мінск 2019, 604 c. [Saǔka Z., Belaruskaâ cyvilizacyâ ǔ Amèrycy. Pâc'dzâsât gadoǔ BelaruskaAmèrykanskaga Zadzinočan'nâ 1949-1999. Padzeì. Dakumènty. Uspaminy. Pèrsanalìi, Mìnsk 2019, 604 s.].

Станкевіч С., У новых краёх - новыя заgаньні, “Бацькаўшчына”, 1.06.1949, № 13 (57), c. 1-2 [Stankevič S., U novyh kraëh - novyâ zadan'nì, "Bac'kaǔščyna", 1.06.1949, № 13 (57), s. 1-2].

Юрэвіч Л., Летапісны звоg сусьвету Чалавека Сьвеgамага. Гісторыя газэтаў “Бацькаўшчына" й "Беларус" (1947-2000), Менск 2006, 256 с. [Ûrèvì̌ L., Letapisny zvod sus'vetu Čalaveka S'vedamaga: Gìstoryâ gazètaǔ "Bac'kaǔščyna" j "Belarus" (19472000), Mensk 2006, 256 s.].

Як выgавалі “Спаgчыну”. Да 135-гоggзя ag нараgжэння і 75-гоggзя смерці Янкі Купалы, укл. Н. Гардзіенка, Л. Юрэвіч, Мінск 2018, 290 с. [Âk vydavali “Spadčynu”. Da 135-goddzâ ad naradžènnâ ì 75-goddzâ smerci Ânkì Kupaly, ukl. N. Gardzìnka, L. Ûrèvič, Mìnsk 2018, 290 s.]. 
Янка Купала й Якуб Колас на Захаgзе, Нью Ёрк 1985, 350 с. [Ânka Kupala j Âkub Kolas na Zahadze, N'û Ërk 1985, 350 s.].

Belarusian Publishing in the West. A Bibliography - Periodicals = Беларускі й беларусавеgны gрук на Захаgзе. Бібліяграфія - Часапісы, газэты, New York 2004, XX+152 с. [Belarusian Publishing in the West. A Bibliography - Periodicals = Belaruskì j belarusavedny druk na Zahadze. Bibliâgrafiâ Časapisy, gazèty, New York 2004, XX+152 s.].

Byelorussian Statehood, New York 1988, 398 p.

Kipel V., Kipel Z., Belarusian Publishing in the West. A Bibliography, New York - Warsaw 2006, XVI+841 p. 


\title{
Беларуская культура як элемент беларускай ідэнтыфікацыі імігрантаў у Аргенціне
}

\author{
Belarusian culture as an element of Belarusian identification among \\ immigrants in Argentina
}

This article is devoted to the Belarusian immigrants in Argentina and the study of their ethnic and national identification. Until 1991 Belarusians in Argentina were a numerically small ethnic group, which due to the absence of an independent Belarusian state was not noticeable to the Argentinians. The elements of Belarusian culture kept up by immigrants (such as language, traditions, songs, dances, cuisine and folk costumes) are highlighted and described. Special attention is paid to the analysis of the development of the Belarusian language among immigrants and their descendants. The cultural characteristics of immigrants from the Belarusian Polesie (Palesse) are also identified. The article summarizes the practical experience in the development of Belarusian culture in pro-Soviet organizations of immigrants, their use of both folklore and the work of Soviet cultural figures (writers, composers). The influence of the BSSR and its institutions on Belarusians in Argentina is discussed. The educational activities of the members of the Association of Belarusians in Argentina as well as the participation of the immigrants' descendants in ethnic festivals in the states of Buenos Aires and Misiones are noted. The factors that currently allow for the preserving of Belarusian culture in the former clubs of Soviet citizens are pointed out. The author concludes that culture is an important element of the Belarusian identification of immigrants and their descendants in Argentina.

Ke y w ords: Belarusian immigrants in Argentina, Belarusian diaspora, Belarusian identification, Belarusian culture, pro-Soviet organizations in Buenos Aires

Kultura białoruska jako element białoruskiej identyfikacji wśród imigrantów w Argentynie

Artykuł poświęcony jest imigrantom białoruskim w Argentynie oraz badaniu ich identyfikacji etnicznej i narodowej. Stwierdzono, że do 1991 r. Białorusini w Argentynie stanowili niewielką liczebnie grupę etniczną, która ze względu na brak samodzielnego państwa białoruskiego była niezauważalna dla mieszkańców Argentyny. Podkreślono i opisano elementy kultury białoruskiej (takie jak język, 
tradycje, pieśni, tańce, kuchnia, strój ludowy), których nosicielami byli imigranci. Szczególną uwagę zwrócono na analizę rozwoju języka białoruskiego wśród imigrantów i ich potomków. Sformułowano charakterystykę kulturową imigrantów z białoruskiego Polesia. Artykuł podsumowuje praktyczne doświadczenia rozwoju kultury białoruskiej w prosowieckich organizacjach imigrantów, ich wykorzystanie zarówno folkloru, jak i twórczości sowieckich postaci kultury (pisarzy, kompozytorów). Określono wpływ BSRR i jej instytucji na Białorusinów w Argentynie. Opisano działalność edukacyjną członków Stowarzyszenia Białorusinów w Argentynie oraz udział potomków imigrantów w festiwalach etnicznych w stanach Buenos Aires i Misiones. Wskazano czynniki, które obecnie pozwalają na zachowanie kultury białoruskiej w byłych klubach obywateli radzieckich. Autor konkluduje, że kultura jest ważnym elementem białoruskiej identyfikacji imigrantów i ich potomków w Argentynie. Słowa kluczowe: białoruscy imigranci w Argentynie, białoruska diaspora, identyfikacja białoruska, kultura białoruska, organizacje prosowieckie w Buenos Aires

Беларусы да 1991 года не мелі ўласнай суверэннай дзяржавы і перасяляліся за акіян з Расійскай імперыі (да 1914 года) і з ІІ Рэчы Паспалітай (19211939), а таксама ў якасці бежанцаў з СССР пасля Другой сусветнай вайны. Нешматлікія беларусы з Расійскай імперыі не адзначыліся на ніве грамадскай дзейнасці, а міжваенныя імігранты (каля 20 тысяч беларусаў) стварылі у 1939 годзе прасавецкую Федэрацыю беларускіх таварыстваў і арганізацый у Аргенціне (Беларускую федэрацыю). Пасля 1945 года ў “Рэспубліку Срэбра” прыехала некалькі сотняў бежанцаў (дыпісаў), якія канфліктавалі са "старой” іміграцыяй і якія стварылі Згуртаваньне беларусаў у Аргентыне (ЗБА). Прадстаўнікі кожнай хвалі перасялення мелі характэрныя рысы нацыянальна-дзяржаўнай ідэнтыфікацыі. Першая хваля не вылучала сябе з “агульнарускага" асяроддзя, а другая разглядала Беларусь як неад'емную частку СССР: у 1950-х гадах замест Беларускай федэрацыі беларусы разам з украінцамі стварылі клубы савецкіх грамадзян (імя Максіма Горкага, імя Мікалая Астроўскага, імя Вісарыёна Бялінскага, імя Аляксея Талстога і іншыя). Паваенныя бежанцы, наадварот, лічылі Беларусь дзяржавай, акупаванай расійскім бальшавіцкім рэжымам. Пры ўсёй розніцы палітычных перакананняў аб'яднальнай рысай прадстаўнікоў адзначаных хваль была беларуская культура, якая ў Аргенціне выяўлялася ў мове, традыцыях, народным строі, песнях, танцах і г.д.

Яскравай адметнасцю нашых суайчыннікаў з'яўляецца беларуская мова. Нават калі ў пачатку XX стагоддзя расейскія ўлады не прызнавалі

1 C. Partacz, Ukraińcy w Polskich Siłach Zbrojnych w czasie II wojny światowej, [y:] Polska - Ukraina. Trudne pytania, t. 9, Warszawa 2002, c. 89-129. 
беларусаў у якасці асобнага народа, вясковая гаворка ў заходніх губернях сведчыла аб унікальнасці жыхароў гэтай імперскай правінцыі. Тая ж акалічнасць прысутнічала і за мяжой: расейскія манархісты, распавядаючы аб беларусах, перадавалі іх моўны каларыт. Так, пасля Другой сусветнай вайны ў Буэнас-Айрэсе газета "Наша страна" паведамляла аб жаданні міжваенных імігрантаў пераехаць у ССсР і прыводзіла словы "Петруся", які казаў, што едзе "на бацькаўшчыну"2. Дарослыя імігранты-беларусы не вывучалі іспанскую мову, засвоілі яе на нізкім узроўні, які дазваляў толькі падтрымліваць элементарныя ўзаемаадносіны на працоўным месцы ці у раёне пражывання. У коле родных і блізкіх знаёмых яны размаўлялі на матчынай мове: "У сям'і размаўлялі па-беларуску. Калі мама трапіла ў шпіталь, то нават да доктара звярталася па-беларуску”з.

У Аргенціне асаблівасцю міжваенных імігрантаў з Заходняй Беларусі было тое, што сярод іх была вялікая доля (39\%4) выхадцаў з Палескага ваяводства. Палешукі размаўлялі на сваіх дыялектах, блізкіх да ўкраінскай мовы: "Белорусский иллюстрированный календарь на 1943 год" (БуэнасАйрэс 1942) адзначаў, што "шматлікія беларускія эмігранты, асабліва з Палесся, мала адрозніваліся ад украінцаў, як у мове, так і ў традыцыях. Самі не маглі вызначыць, беларусы яны ці ўкраінцы, і ахвотна далучаліся да ўкраінскіх арганізацый" і ўкраінцаў у Аргенціне дазваляла палешукам культурна пачуваць сябе даволі камфортна. Калі уураджэнец Драгічыншчыны Сцяпан Самасюк выказваў у лістах пачуцці ў дачыненні да бацькаўшчыны, то можна было заўважыць яго моўны дыялект:

Я у чужой стране страдаю

И об тибе я упоминаю

Мой вольны край Белорусс

Я человек ест русс

И тобою я горжус

Мой край свободны Белорусс
Что там нас паны терзали

И свободы ни давали,

Заграницу высылали,

Там нам жизнь обещали.

В чужой стране нет жизни в нас

И мы все думаим о вас.

2 М. Бойков, Козырь или повесть о том, как Петрусь Лукашук езgил на родину, "Наша страна", 7.04.1955, с. 5.

3 С. Шабельцев, Иммигранты-чакареро из II Речи Посполитой в Аргентине и Парагвае. Воспоминания белорусов и украинцев, Минск 2011, с. 52.

${ }^{4}$ В. Коваль, Узаемасувязі беларускай і ўкраінскай gыяспар у міжваенны перыяg, Мінск 2012, с. 305.

5 Белорусская эмиграция в Аргентине и ее Культ-Организации, "Белорусский иллюстрированный календарь на 1943 год" 1942, с. 81-82. 
Как я вспомню про тибя

Слезы льются у миня. я где родился, там умру,

Поеду на родину свою 6 .

Гутарковая беларуская мова з'явілася ў Аргенціне з прыездам першага беларуса дзесьці ў канцы XIX стагоддзя. Літаратурную беларускую мову ў Аргенціну прынеслі імігранты міжваеннага перыяду, хаця яны выкарыстоўвалі ў сваім друку (“Новая газета”, “Эхо”, “Наш голос", "Наша газета"), у асноўным, рускую мову. "Белорусский иллюстрированный календарь на 1941 год” (Буэнас-Айрэс 1940) тлумачыў гэта тым, што “ўраджэнцы Заходняй Беларусі, у большасці, лепш валодаюць рускай мовай, а не беларускай, таму што ні ў царскай Pacei, ні ў панскай Польшчы беларускіх школ зусім не было"7. Брак беларускай адукацыі прыводзіў да таго, што нават калі імігрант у Аргенціне ліставаўся з рэдакцыяй віленскай газеты "Biełaruskaja Krynica”, то выбачаўся за свае нязграбныя тэксты "біларускай пісоўні зусім не знаю"8.

Імігранты ўсведамлялі сімвалічнасць мовы для сваёй ідэнтыфікацыі, і ў тым жа "Белорусском иллюстрированном календаре на 1941 год" прадмову надрукавалі на трох мовах (іспанскай, рускай і беларускай), праваслаўны каляндар - выключна па-беларуску. Амаль усе публікацыі календара напісаны па-руску, але былі (хаця і рэдка) таксама беларускія артыкулы і вершы. Наступны "Белорусский иллюстрированный календарь на 1942 год" (Буэнас-Айрэс 1941) нават прадставіў беларускі алфавіт і кароткае тлумачэнне беларускага правапісу. Але ў прасавецкіх арганізацыях вучылі рускую мову і абгрунтоўвалі гэта тым, што яна адна з самых папулярных у свеце і з'яўлялася мовай міжнацыянальнай камунікацыі ў СССР.

Амбасада СССР, якая з'явілася ў Аргенціне ў 1946 годзе, не садзейнічала вывучэнню беларускай мовы ў прасавецкіх таварыствах. Міхал Моўчан, які з натхненнем дэкламаваў урыўкі з паэмы Якуба Коласа Новая зямля, сведчыў, што “была нейкая ўніфікацыя, русіфікацыя, каб ліквідаваць нацыянальнае пытанне"9. Гэта прывяло да таго, што мастацкая літаратура і прапаганда на беларускай мове не былі папулярны сярод імігрантаў. У студзені 1954 года

6 Таварыства “Радзіма”, [Верш С. Самасюка ад 24.12.1934].

7 Выдавецтва, Праямова, “Белорусский иллюстрированный календарь на 1943 год" 1942, с. 4.

8 Беларускі дзяржаўны архіў-музей літаратуры і мастацтва [далей: БДАМЛіМ], ф. 3, воп. 1, спр. 44: Ліст Ф. Паўлоўскага ад 22.09.1935, л. 6 об.

${ }^{9}$ С. Шабельцаў, Беларусы ў Аргенціне: грамаgская gзейнасць і рээміграцыя ў СССР (1930-1960-я г.). Зборнік дакументаў і ўспамінаў, Мінск 2009, с. 166, 177. 
амбасада СССР у Буэнас-Айрэсе звярнулася да Беларускага таварыства па культурных сувязях з замежнымі краінамі (Мінск) з рэкамендацыяй:

неабходна ўлічваць, што вельмі нязначная колькасць грамадзян-беларусаў могуць, ды і то з цяжкасцю, чытаць публікацыі на беларускай мове. Таму просім накіроўваць нам друкаваныя матэрыялы для перадачы таварыству “Беларускае вогнішча" і іншым таварыствам савецкіх грамадзян на рускай мове, якую уусе гэтыя грамадзяне ведаюць ці вывучаюць ${ }^{10}$.

Сярод імігрантаў міжваеннага перыяду ўсё ж былі беларусы, якія прагнулі друкаванага слова на роднай мове, хаця ніжэйпрыведзены ліст выглядае як выключэнне з агульнага правіла:

Б-с Айрас. 20-4-76

Пішыць старый амігрант з далёкай Аргантыны ў Редакцыю "Голас Радзімы" з просьбай.

Не знаю пісаць граматычна па-беларуску, але стараюся як магу.

Зайшоў я аднаго разу да маяго ачизника і уувідзяў, на стале ляжиць газета “Голас Радзімы”. Я папрасіў, кап газетку падарілі. Прінес да хаты, жонка загледзіла і кажіць: глядзі ня загубі, і хачу пачітаць.

Скора мне будзіць 77 гадоў і 50 гадоў як пакінуў сваю сям'ю і родную Старую Вёску Свірскай воласці (gminy). Мне і жонцы маей ужо асталося ня многа жыць. Адведаць Радзіму сышла пара, але мыслі блукаюць па межах, каторых, як ведама, іх ужо няма.

Прайшло палавіна века, мовы не забыў, помню, як маці навучыла, і гэтай самай мовай прашу Радакцыю "Голаса Радзімы” не адказаць і пріслаць газетку "Голас Радзімы”, за што згарі дзякую з паважаннем. М. Гуйский"1.

У адрозненні ад міжваенных імігрантаў антысавецкае ЗБА выкарыстоўвала ў справаводстве беларускую мову. Таксама на ёй ліставаліся паміж сабой сябры гэтай арганізацыі, а падчас гарбачоўскай перабудовы менавіта яны віталі адраджэнне беларускай культуры і цешыліся, калі да іх даходзіла роднае слова з радзімы.

Нашчадкі імігрантаў, як правіла, хутка авалодвалі іспанскай і не ведалі беларускай мовы. Ужо ў 1942 годзе “Белорусский иллюстрированнный календарь на 1943 год” пісаў, што дзеці, скончыўшы аргенцінскія школы, “ад сваёй мовы сталі

10 Нацыянальны архіў Рэспублікі Беларусь [далей: НАРБ], ф. 914, воп. 2, спр. 32 с, л. 2.

11 НАРБ, ф. 1267, воп. 3, спр. 90, л. 1. 
адвыкаць, і нават над ёй пасмейваюцца, лічачы яе ніжэйшай і непатрэбнай”12. У створаных у пачатку 1950-х гадоў клубах савецкіх грамадзян моладзь не размаўляла па-беларуску: “Збіраліся там усе: беларусы, украінцы, рускія, літоўцы. [...] Больш сталыя размаўлялі на сваёй роднай мове, а моладзь ужо на іспанскай”зз. Нават у беларускіх нязмешаных сем'ях дзеці імкнуліся гаварыць на мясцовай іспанскай мове (на "касціжы", ад "lengua castellana" - кастыльская [іспанская] мова). Тут адбывалася пастаянная барацьба паміж бацькоускай “пародай” і аргенцінскай “пашай”. Здаралася, як у сям’і Церабеяў, мовы змешваліся і перакручваліся: “«Зіна, пафундуй мне мату». «Фундуй» - гэта «падай», «матэ» - «гарбата»"14. у беларускіх сем'ях дзеці, як правіла, толькі разумелі мову бацькоў, а для ўнукаў яна была зусім невядомая. Міхал Гуйскі гаварыў з дзецьмі "руска-беларускімі словамі", але тыя адказвалі "на касціжы": “Пажаніліся з мясцовымі, а ўнукі ня ведаюць ніводнага слова, так кажуць, як іх маці вучыць” 15 .

Народныя традыцыі маглі стаць яшчэ адным культурным маркерам выхадцаў з Беларусі. Аднак, для гэтага не было спрыяльных абставін: беларусы знаходзілі працу ў аргенцінскіх гарадах, і масава сяліліся ў Буэнас-Айрэсе і яго прадмесцях. У буйным мегаполісе яны суседнічалі з іншыі імігрантамі-еўрапейцамі, вясковыя традыцыі мала падыходзілі да новага жыцця. Нават калі беларусы займаліся сельскай гаспадаркай на чакрах (фермах), то ў субтрапічным клімаце паўднёвага паўшар'я Зямлі не было месца для народных прыкмет, якія распаўсюджаны на радзіме. Традыцыі маглі праявіцца ў варунках, звязаных з рэлігіяй у праваслаўнай царкве С. Самасюк "аднойчы быў за кума, і хрысціў зямляк там дзяцей", то як хросны бацька "пакупіў ім усім белыя касцюмы"”. Кастусь Мерляк і Ганна Губерт ажаніліся у 1950 годзе ў Буэнас-Айрэсе са сватамі, дружкамі, дружбакамі"7.

Вяселле, якое арганізоўвалі імігранты на поўначы Аргенціны (правінцыя Місьёнес), апісала Зянона Забчук, народжаная тут у беларуска-ўкраінскай сям'і. Святочнае мерапрыемства цягнулася некалькі дзён, а то і два тыдні. Госці прыязджалі на вазках, упрыгожаных рознакаляровымі стужкамі; жаніх са сватамі ехалі на конях, а нявеста з падружкамі ў вянках ішлі

\footnotetext{
12 Белорусская эмиграция в Аргентине и ее Культ-Организации, с. 80.

13 С. Шабельцаў, Беларусы ў Аргенціне, с. 308.

14 Ibidem, s. 311

15 НАРБ, ф. 1267, воп. 3, спр. 90, л. 7.

16 Таварыства “Радзіма”, [Ліст С. Самасюка ад 7.04.1966].

17 К. Мерляк, Дзейнасць Кастуся Мерляка на Эміграцыі, Нью Ёрк 1992, с. 59.
} 
пешшу. Усе спявалі мажорныя вясельныя песні. Пасля вянчання ў царкве свята пачыналася ў доме нявесты: "Маладыя прымаюць бласлаўленне бацькоў і павінны адламаць адной рукой кавалак каравая, які сімвалізуе плоднасць і дабрабыт. Потым п'юць ваду, як сімвал чысціні, каштуюць соль, як неад'емную частку кахання, і водку, як знак весялосці!” Хутка пачыналася застолле, танцы, песні: "Я добра помню свайго бацьку, які спявае сваю любімую песню Сценька Разін”. Вяселле працягвалася ноччу, а пасля перамяшчалася ў дом жаніха: маладыя і госці ехалі на павозках, на адной з якіх знаходзіуся пасаг нявесты: падушкі, абрусы, бялізна з вышыўкай. У доме жаніха цырымонія паўтаралася, а напрыканцы маладая жонка дэманстравала сваё майстэрства гатовіць ежу. I гэта страва "расхідны боршч"18.

У Аргенціне дзяржаўнай рэлігіяй з'яўляецца каталіцызм, і праваслаўная царква (адзін з уплывовых інстытутаў традыцыйнага грамадства) рабіла беларусаў адметнымі сярод агульнай масы жыхароў краіны: Ніна Лабаноўская распавядала, што яе бацькі “былі рэлігійныя праваслаўныя людзі. Я амаль кожную нядзелю з мамай хадзіла ў царкву. Яна ўсё жыццё праходзіла ў хустцы, прывыкла"19. Іван Церабей ва ўзросце шасці гадоў быў ахрышчаны ў праваслаўнай царкве ў Буэнас-Айрэсе:

Былі там цэрквы капітальна пабудаваныя, а былі цэрквы хатнія, якія ладзілі, не маючы магчымасці пабудаваць капітальны сабор. Гэта звычайны пакой, але ставіцца іканастас, іконы развешваюцца, і вядуцца службы. Мае бацькі былі рэлігійныя, але ў царкву не хадзілі. Яны праваслаўныя, выконвалі царкоўныя абрады, святы, на Вялікдзень пяклі караваі, фарбавалі яйкі. Я ж адзіны раз быў у царкве, калі мяне хрысцілі².

Хрышчэнне нашчадкаў паводле праваслаўнага абраду звязвала ix са сваімі беларускімі продкамі: "Тут мы ўсё называемся артадокс, гэта значыць праваслаўныя. Калі мы сваіх дзяцей не пахрысцілі на праваслаўных, то яны застануцца каталікамі, а мы, патрыёты, злучаемся па веры і мове, па расе, але сярод нас сапраўдных вернікаў няма"21. Паколькі глыбока веруючых сярод беларусаў было няшмат, праваслаўныя святы станавіліся падставай, каб сабрацца і павесяліцца разам з суайчыннікамі. Гэта праяўлялася нават у прасавецкіх арганізацыях, дзе, па словах Алены Карчык, "адзначалі ўсе

\footnotetext{
18 Z. Arciuch, Mis raises: la tierra de mis padres, Obera 2016, с. 39-42.

19 С. Шабельцев, Иммигранты-чакареро из II Речи Посполитой, с. 52.

20 С. Шабельцаў, Беларусы ў Аргенціне, с. 312.

21 Таварыства "Радзіма”, [Ліст С. Самасюка ад 7.04.1966].
} 
святы - нават Пасху Хрыстову. Праваслаўнай царквы ў Берыса не было, але і ў грэцкую нашы не хадзілі - яны ўсе атэісты былі. А адзначалі, мабыць, па традыцыі"22.

Кіраўніцтва прасавецкіх арганізацый не ставіла мэтай падтрыманне праваслаўных традыцый (СССР з'яўляўся дзяржавай афіцыйнага атэізму), і звычайна рэлігійныя святы беларусы адзначалі ў сваіх сем'ях. Пры гэтым, па словах Эміля Цяўлоўскага, адбывалася ўзаемапранікненне беларускай і аргенцінскай культур: аргенцінцы уу свае калядныя абрады ўлучылі беларускія звычаі (напрыклад, класці сена пад абрус), а пасля гэтага ганарацца імі, як нечым сваім арыгінальным. Э. Цяўлоўскі пакінуў апісанне суайчыннікаў, якія жылі ў сталіцы прыняўшай іх краіны, і адзначыў захаванне часткі беларускіх калядных звычаяў - тое, што з адыходам старога пакалення і аргенцінізацыяй моладзі было страчана:

Ходзячы па залітых агнямі вуліцах некаторых раёнаў Буэнас-Айрэсу, ужо здалёк, па вясельным гомане беларускай мовы, мяшанае напалам зь гішпанскаю, можна даведацца, што жывуць тут Беларусы. Паказваюць на гэта - голасна сьпяваныя беларускія калядкі. Хоць аргентынскія Беларусы пераважна даўно ўжо, як пакінулі бацькаўшчыну, але звычаяў бацькоў яны трымаюцца. У кажнай беларускай сям'і абавязкава рыхтуюць Куцьцю. Аднак, тут яе не ставяць у покуце на сене, як некалі ўдома, а спажываюць яе - на дварэ, у гэтак званым “патыё”, выкладаным каменнымі плітамі або мазаікай нутранным панадворку, аплеценым часта вінаградам. Традыцыйныя посныя стравы, як квас з грыбамі, селядцы, розныя рыбы, кісель з макам ды іншае, - мяшаюцца тутака ўжо часта із стравамі аргентынскымі, пераважна мяснымі. Прысмакі каляднае аргентыскае кухні, гэта салодкая бабка, смажанае парасё, ды розная іншая смажына - індыкі, куры ці проста вялікі кавалак мяса, ялавічыны. Запіваюць усё гэта яблачным сідрам, вінаградным сокам, содаю. Беларусы, аднак, застаюцца найчасьцей верныя старой беларускай “чарачцы”. Усё мяса, патутэйшаму “асадо”, пячэцца уу Аргентыне на дварэ, над гарачым вугальлем, насаджанае на адмысловыя залезныя крыжульцы. Паводля тутэйшага звычаю, пякуць і даглядаюць мяса вылучна мужчыны. [...] Сьпячы добрае «асадо», каб яно было мякое й духмянае й надавалася, як закуска пад віно, - ня гэтак ужо й проста. Аднак, нашыя беларускія дзядзькі цалком апанавалі гэтае майстэрства й пякуць “асадо” бадай ня горш, чымся Аргентынцы ${ }^{23}$.

Да захавання рэшткаў традыцыйнай культуры можна аднесці прыхільнасць імігрантаў да беларускай кухні. Аргенцінская ежа і напоі

22 С. Шабельцаў, Беларусы ў Аргенціне, с. 300.

23 Э.Ц., Як аргентынскія беларусы сьвяткуюць каляgы, "Беларус", студзень 1965, c. 6 . 
заўсёды былі добрай якасці, але недахоп звычных страў мог прывесці імігрантаў да сітуацыі пэўнага дыскамфорту і абвастрэння настальгіi. Канстанцін Арцюх па прыездзе ў Місьёнес прасіў жонку прыгатаваць боршч, але "з чаго яго зварыць? 3 мясам праблем не было, і рыба была ў рэчках, і звяроў забівалі і пеклі мяса. Але трэба боршч. А там ёсць такая расліна пад назвай «трэболь», якая кісленькая і расце ў лесе. І з гэтага мы рабілі боршч. А потым былі ўжо і буракі"24. Пра гастранамічны беларуска-аргенцінскі сімбіёз у сваёй сям’і распавядаў І. Церабей: "Мой дзядуля першае, што зрабіў, калі прыехаў у Аргенціну - гэта пабудаваў рускую печ. I ў рускай печы бабуля пякла пірагі, бабка мне вельмі падабалася. А штодзённая ежа там - кавалак мяса з косткай у рондалі і вельмі шмат гародніны (салодкая бульба, гарбуз, зеляніна)"25.

Элементы народнай культуры былі неад'емнай часткай не толькі сямейнага жыцця беларусаў, а таксама тэатральных пастановак, канцэртаў, імпрэз у грамадскіх арганізацыях.

Першае беларускае публічнае прадстаўленьне ў Буэнас-Айрэсе і на абшары Аргентынскай Рэспублікі наагул, адбылося 25 чэрвеня 1938 г. Ладзіла яго Беларускае Т-ва "Культура". Аб гэтым сэнсацыйна-гістарычным здарэньні ў жыцці беларускай аргентынскай эміграцыі, усё Буэнас-Айрэс было паведамленае адмысловымі лятучкамі, каторыя ў мовах беларускай, расейскай і гішпанскай усюды і ўсім абвяшчалі: "Навіна, якой ня бывала! Першы раз у Аргентыне ў беларускай мове! Дня 25 чэрвеня а 9 гадзіне вечара ў выгадным салёне [неразборліва], Rincon 1141, Беларускае Таварыства «Культура» наладжывае вялікі спэктакль і фамілійную забаву. У праграме: Мікітаў лапаць... Беларускія дэклямацыі... Скокі... Хто пабачыць камэдыю Мікітаў лапаць, перанясецца мысьляй на сваю далёкую бацькаўшчыну, пабачыць жыцьцё роднай вёскі, пачуіць на сцэне родную мову і ўспомніць пра сваё далёкае прошлае"26.

Рэпертуар сцэнічных п'ес быў абмежаваны, бо іх выбар у Аргенціне быў мінімальны. Артыкул "Белорусского иллюстрированного календаря на 1941 год" сведчыць, што нашы землякі паставілі Паўлінку Янкі Купалы ${ }^{27}$, і гэта пацвярджаюць успаміны Васіля Рамановіча, маці якога выконвала ролю ў гэтай камедыі ${ }^{28}$. М. Башко, які апісваў работу драмгуртка Беларускай

${ }^{24}$ С. Шабельцаў, Беларусы ў Аргенціне, с. 346.

25 Ibidem, с. 315.

26 БДАМЛіМ, ф. 3, воп. 1, спр. 48, л. 44-45.

27 М. Бошко, Театр, “Белорусский иллюстрированный календарь на 1941 год” 1940, C. $155-159$.

${ }^{28}$ с. Шабельцаў, Беларусы ў Аргенціне, с. 205-206. 


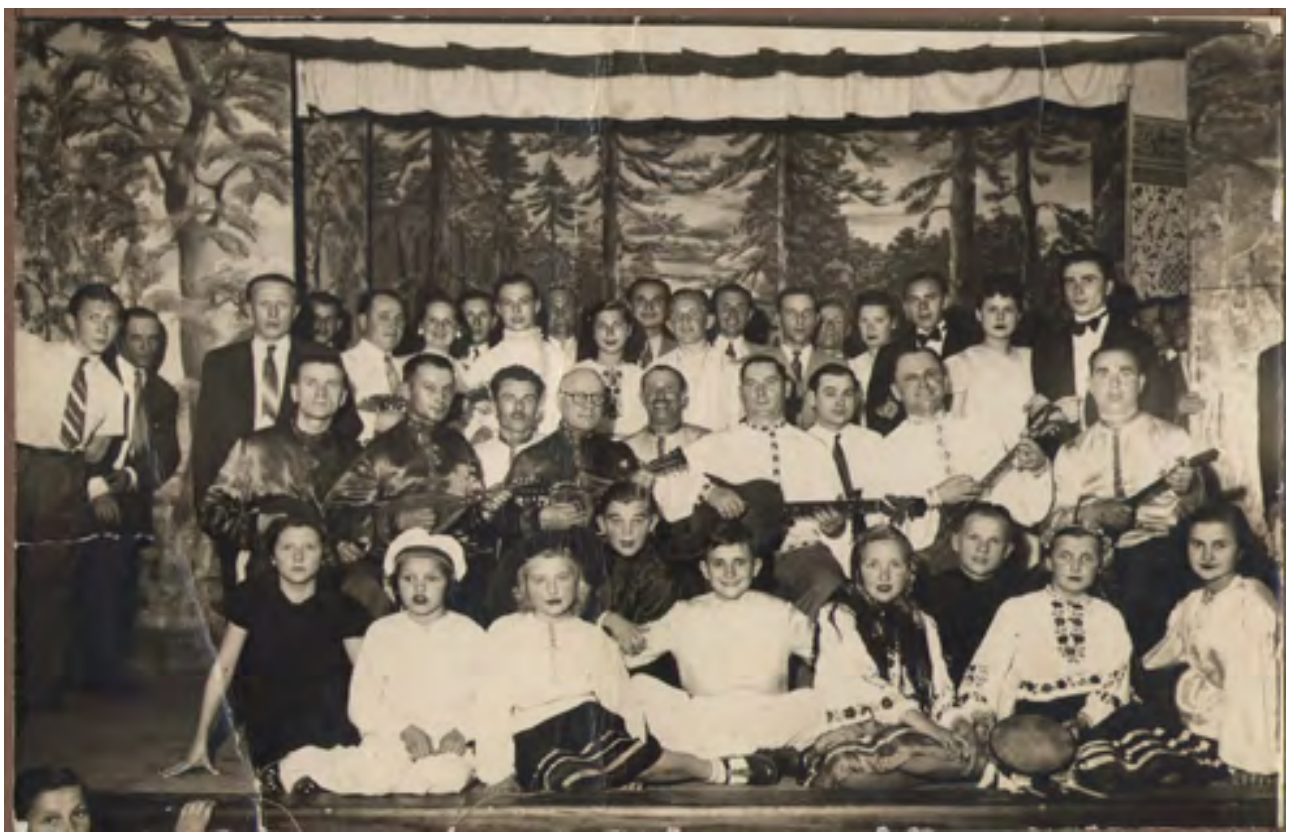

Струнны аркестр і драмгурток Беларускага таварыства "Белавеж” (“Белорусский иллюстрированный календарь на 1943 год”, Буэнос-Айрес 1942, с. 101)

федэрацыі, сярод творчых поспехаў называў драму Кандрата Крапівы Партызаны (дэманстрацыя адбылася 21 верасня 1940 года). Гледачам спадабаўся вобраз дзеда Бадыля, створаны Клімашэўскім: акцёр быў з барадой, парай лапцей у запас і поўным мяшком. Ролю Рыгора выконваў І. Драздоўскі, Данілы Дрыля - М. Антановіч, Кацярыны - Роза Васіленка, Батуры - М. Зазуля, які акрамя таго суправаджаў тэкст п'есы ігрой на гармоніку ${ }^{29}$. У наступным, калі уу Буэнас-Айрэсе з'явілася Амбасада СССР, імігрантам перадаваліся для пастаноўкі творы савецкіх пісьменнікаў, і неабавязкова беларускіх: М. Моўчан, напрыклад, выконваў ролю марака Смірнова з п'есы Аляксандра Карнейчука Калінавая рошча ${ }^{30}$. Але на сцэне былі і беларускія пастаноўкі. М. Моўчан, калі уубачыў пажоўклае сцэнічнае фота імігранта Івана Куровіча, узгадаў, як той даводзіў да істэрычнага смеху ўсіх гледачоў фразай "Саўка збіўся з панталыку" (словы са Збянтэжанага Саўкі аўтарства дзеяча беларускага нацыянальнага адраджэння Леапольда Родзевіча).

29 М. Бошко, Театр, “Белорусский иллюстрированный календарь на 1941 год” 1940, C. $157-158$.

30 с. Шабельцаў, Беларусы ў Аргенціне, с. 173. 
Неад'емнай часткай культурнай самадзейнасці ў прасавецкіх таварыствах было выкананне народных песень. М. Моўчан упадабаў украінскія (асабліва гуцульскія) песні: “Дзяучыны сядуць на лавачцы і пачынаюць спяваць. Пелі нацыянальныя, і беларускія песьні. Рускія песьні пачалі пець толькі пасля вайны: Кацюшу раней ніхто ня ведаў"31. Кіраўніцтва прасавецкіх клубаў звярталася ў Мінск з просьбамі дапамагчы ў атрыманні тэкстаў песень і нот, грампласцінак з запісамі беларускіх песень. Перыядычна Глаўліт БССР даваў на гэта згодуз32.

Падчас выканання песень і народных танцаў артысты апраналіся ў народныя строі, а дэкарацыямі былі малюнкі роднай прыроды ці інтэр'ер сялянскай хаты, дзе можна уббачыць ручнікі і посцілкі. Такія ілюстрацыі масава прадстаўлены ў нумарах “Белорусского иллюстрированного календаря". Для фота на памяць у беларускае адзенне любілі апранаць дзяцей, і маці самастойна рабілі вышыўку і арнамент па традыцыях, распаўсюджаных у іх роднай мясцовасці.

Наяўнасці шматлікіх элементаў народнай культуры было недастаткова, каб аргенцінцы "уббачылі" беларусаў і вылучылі іх у асобную групу:

[...] мясцовае насельніцтва ніколі не жадала разбірацца, хто паляк, хто літовец, хто ўкраінец, хто беларус. У іх адна характарыстыка - "паляка". Усе мы для мясцовых жыхароў "паляка"33; хто такія беларусы, яны ўяўлення ня мелі. Рускіх уявіць яшчэ маглі б. Нас называлі ці "рускімі”, ці “палякамі”. А каб гаварылі “беларусы”, "украінцы”, такога не было 34.

У такіх абставінах вялікую значнасць мела асветная дзейнасць паваенных бежанцаў са Згуртаваньня беларусаў у Аргентыне, якія апублікавалі нацыянальную некамуністычную версію беларускай гісторыі ў брашуры Bielorusia y los bielorusos en la Republica Argentina ${ }^{35}$. Для папулярызацыі ведаў аб Беларусі былыя дыпісы выкарыстоўвалі мясцовыя радыёстанцыі. у 1954 годзе на станцыі “Эксцэльёр” ЗБА правяло праграму, прысвечаную Дню Незалежнасці Беларусі (25 сакавіка) - па аргенцінскім радыё прагучаў гімн Магутны Божа, прайшла інфармацыя пра Беларускую Народную Рэспубліку і “акупацыйную палітыку расейскага бальшавізму”. Таксама

\footnotetext{
31 Ibidem, c. 175-176.

32 НАРБ, ф. 914, воп. 1, спр. 18, л. 120-121, 133.

33 С. Шабельцаў, Беларусы ў Аргенціне, с. 202.

34 Ibidem, c. 311-312.

35 Bielorusia y los bielorusos en la Republica Argentina, Buenos-Aires 1953, c. 42.
} 
перадаваліся беларускія песні “з тлумачэннем народнага фальклору”. Гэтую праграму потым паўтарылі дзве іншыя радыёстанцыіз ${ }^{36}$

Узмацненню беларускай ідэнтычнасці сярод прасавецкіх імігрантаў міжваеннай хвалі спрыяла наяўнасць БССР у складзе СССР. На святочных мерапрыемствах нават камуністычнага характару выхадцы з Беларусі выкарыстоўвалі элементы народнай культуры ў якасці пацвярджэння сваёй нацыянальнай унікальнасці. Калі ў клубе імя Мікалая Астроўскага ў 1954 годзе адзначалі гадавіну Кастрычніцкай рэвалюцыі, 16 дзяўчат у нацыянальных строях савецкіх рэспублік (безумоўна, сярод іх была і беларуска) расказвалі "аб дасягненнях эканамічнага і культурнага жыцця народаў, якія яны прадстаўлялі" ${ }^{2}$.

Актыўнасць беларусаў у Аргенціне ў 1960-я гады скарацілася з-за масавай рээміграцыі прасавецкіх імігрантаў і пераезду ў ЗША значнай колькасці сябраў ЗБА. Да таго ж аргенцінскія хунты ў канцы 1950-х гадоў па палітычных прычынах спынілі дзейнасць клубаў савецкіх грамадзян. Аднак у 1960-я гады клубы аднавілі сваю дзейнасць і ўсталявалі кантакты з культурнымі таварыствамі па сувязях з суайчыннікамі ў Маскве, Кіеве і Мінску. Мінскае Таварыства "Радзіма" высылала да беларусаў у БуэнасАйрэс літаратуру, перыёдыку і сувеніры. Беларусы з Аргенціны маглі наведаць родныя мясціны па запрашэнні "Радзімы”, а таксама запрашалі да сябе ў госці супрацоўнікаў гэтага таварыства і беларускіх артыстаў. Падчас аднаго з такіх візітаў суайчыннікі горача віталі беларускага спевака Мікалая Скорыкава, які выканаў вядомыя народныя песні У месяцы верасні, Зелянеюць лугі, а таксама Мой роgны кут на словы Якуба Коласа ${ }^{38}$.

Супрацоўніцтва імігрантаў з рэспубліканскімі таварыствамі па сувязях з суайчыннікамі, атрыманне гістарычнай, геаграфічнай, займальнай інфармацыі і навін з БССР спрыялі захаванню беларускай ідэнтыфікацыі імігрантаў і часткі іх нашчадкаў. Але Амбасада СССР па-ранейшаму не рабіла аніякіх намаганняў да развіцця беларускай мовы ў прасавецкіх клубах. У 1961 годзе загадчык консульскага аддзела Д. Гвімрадзэ звярнуўся ў Мінск з рэкамендацыяй не пасылаць у Аргенціну беларускамоўную перыёдыку (газету “Звязда" і часопісы “Полымя", “Беларусь”):

36 К. Мерляк, Дзейнасць Кастуся Мерляка, с. 82-83.

37 А. Котовський, На берегах Ла-Плати, Львів 1988, с. 147.

38 Т. Антонава, Аргенцінскія сустрэчы Мікалая Скорыкава. Душа рвецца за марай, “Голас Радзімы”, 28.04.1988, с. 7. 
Усе асобы беларускай нацыянальнасці чытаюць толькі па-руску і па-іспанску. Усе астатнія матэрыялы, якія Вы накіроўваеце, рэгулярна атрымлівае консульскі аддзел, паспяхова распаўсюджваюцца ў калоніi, а таксама выкарыстоўваюцца ў газетах, выдаваемых савецкімі грамадзянамі ${ }^{39}$.

Уваходжанне беларусаў у склад інтэрнацыянальных клубаў савецкіх грамадзян прыводзіла да страчвання ўраджэнцамі Беларусі элементаў беларускай культуры, іх паступовай “саветызацыі” на расейскім падмурку. Гэта выклікала роспач у нацыянальна-арыентаваных беларусаў з паваеннай хвалі іміграцыі. Часопіс “Божым шляхам" сцвярджаў, што на святкавані “савецкай калоніяй” у Буэнас-Айрэсе 50-годдзя Кастрычніцкай рэвалюцыі адбылася кампраметацыя, бо не была прадстаўлена беларуская культура. На сцэне выступалі толькі рускія і уукраінцы, а "калі было свята «савецкіх народаў», дык дзе ж падзеўся народ беларускі? А танец «камарынскі» ў сарафанах ніяк не заменіць ні нашай «лявоніхі», ні нашага нацыянальнага строя, ні роднага слова"40.

Сярод таварыстваў савецкіх грамадзян найбольшую працу па захаванні беларускай культуры праводзіў клуб “Усход” (“Vostok"), размешчаны у горадзе Берыса (правінцыя Буэнас-Айрэс). У 1958 годзе танцавальны ансамбль "Чайка" з гэтага таварыства прымаў удзел у фестывалі фальклору, на які з'ехаліся 60 калектываў з усяе Аргенціны. І першую ўзнагароду атрымала "Чайка" пад кіраўніцтвам Карласа Дзянісені ${ }^{41}$.

Аргенціна на працягу XX стагоддзя праводзіла палітыку па добразычлівай інтэграцыі імігрантаў: папулярнае ў краіне выказванне сцвярджае, што аргенцінцы паходзяць ад караблёў (у сэнсе, што уусе маюць сярод сваіх продкаў прышэльцаў з-за акіяна). Улады талерантна ставяцца да публічнага праяўлення культурных адметнасцей жыхароў, і з 1970-х гадоў на ўзроўні правінцый праводзяцца фестывалі імігрантаў, падчас якіх адбываецца дэманстрацыя традыцыйных народных строяў, песень, танцаў. Сталіцай імігрантаў правінцыі Буэнас-Айрэс абвешчаны горад Берыса, і сябры клуба "Усход” на фестывалі прадстаўляюць беларускую супольнасць.

Эміль Цяўлоўскі у 1979 годзе пабываў на Свяце імігранта ў Берыса і адзначыў, што пры цэнтральнай вуліцы горада знаходзіцца адмысловы блёк, на якім уложаны кафлямі сцягі нацыянальных згуртаванняў: "Ёсьць тут сьцяг савецкае Беларусі, аднак няма агульнасавецкага!" На той жа вуліцы

39 НАРБ, ф. 914, воп. 3, спр. 121, л. 26.

40 Э. Цяўлоўскі, Аргентына - Буэнос Айрэс, "Божым шляхам" 1968, №3, с. 10-11.

41 Э. Цяўлоўскі, “Пайзанас" з Бэрыса, “Беларус", травень 1979, № 265, с. 3, 5. 
наладжаны выстаўкі, і на “беларускай выстаўцы займае цэнтральнае месца вялікі, каля аднаго мэтра бакал, здабыты ансамблем «Чайка» як першая ўзнагарода у 1958 годзе"42. На танцавальным канцэрце беларускі гурток быў адным $з$ найлепшых:

Найперш выступіла восем параў дзяўчатак (школьніцаў), прыгожа аднолькава апранутых у белыя блюзкі, вышываныя гарсэцікі, пацяркі із стужкамі, зялёныя спаднічкі з каляровымі пліскамі, вясёлкі долам, і высокія чырвоныя боцікі. Наступны паказ складаўся з 6-8 параў танцораў больш дарослых. Дзяўчаты, як і ў першай групе, былі апранутыя ў нацыянальныя касьцюмы, толькі ў іншых колерах. Хлопцы мелі вішнёвыя касавароткі, паяскі, цёмнакарычневыя порткі ды чорныя боты. А да выступаў свая, хоць скромная, музыка.

Рэпэртуар быў складзены зь некалькіх песенных мэлёдыяў з рытмам да танцаў (прыкладам: Кацілася чорная галка па лясу або А чыя-ж то хата не замеценая, Лявоніха). Ня ўсе мэлёдыі былі беларускія, яны былі перамешаныя з расейскімі й аргенцінскімі. Але калі моладзь выконвае паказы з энтузіязмам і без заганы, то й публіка прыймае з энтузіязмам. Некаторыя танцы былі акрабатычныя. На працягу ночы штось каля чатырох разоў выступалі "князёўны" ад кажнай этнічнае групы ў сьвяточных вопрадках ${ }^{43}$.

Беларусы ў горадзе Берыса заўсёды бралі ўдзел у Свяце імігрантаў і на мяжы 1970-1980-х гадоў, па-словах Э. Цяўлоўскага, у нашых суайчыннікаў з кожным годам “відаць прагрэс”. у 1982 годзе на фестывалі было 13 этнічных груп, але мала хто прадставіў на сцэне такі вялікі ансамбль як беларусы. У адзін дзень з імі выступалі албанцы, японцы, славакі і армяне: "Наколькі танцы гэтых групаў былі спакойныя, асабліва японская, нагэтулькі беларускія танцаўнікі адзначаліся бадзёрысьцяй і акрабатыкай"44. На конкурсе "Каралева прыгажосці" беларусаў прадстаўляла вучаніца сярэдняй школы Разана Рубаш, а скончылася свята звыклым парадам удзельнікаў у традыцыйных народных строях. У 1982 годзе газета "Gaceta" (горад Ла-Плата) змясціла з парада фота беларусаў, якія шлі пад назвай "Colectividad Bielorusa de Berisso"45. І гэта не адзінкавы выпадак, калі беларусы трапілі на старонкі аргенцінскай перыёдыкі: у верасні 1981 года іх убачылі на першай старонцы чытачы часопіса "Berisso"46.

\footnotetext{
42 Ibidem.

43 Ibidem.

44 Э. Цяўлоўскі, На фестывалі ў Бэрыса, "Беларус", лістапад-сьнежань 1982.

45 Ibidem.

46 Э. Цяўлоўскі, Беларусы уу Бэрыса (Аргентына), “Беларус", люты 1982, с. 3.
} 
Прыклад клуба "Усход" з горада Берыса сведчыць аб выключнай значнасці народнай культуры для захавання беларускай самасвядомасці ў нашчадкаў імігрантаў:

Людзі тут маласьведамыя нацыянальна. Шмат арыентацыі на Савецкую Беларусь, асабліва ў танцах, музыцы, ды нат і сьцяг савецка-беларускі зьмясцілі на абэліску каля помніка Сан Мартыну, гэрою Аргентыны. Моладзь эмігрантаў зь Беларусі, нажаль, ня ведае ані гісторыі краю паходжання сваіх бацькоў, ані іхняе мовы. Карыстаючыся гішпанскай мовай, моладзь ахвоча, аднак, горніцца, да бацькоўскіх традыцыяў - касцюмаў, танцаў, музыкі ${ }^{47}$.

Актыўнасць беларусаў у Берыса пашырала інфармацыю аб Беларусі, але аргенцінцы на масавым узроўні не вылучалі іх з агульнага комплексу «саууетыка». Толькі з 1991 годзе сітуацыя стала мяняцца, бо распад Савецкага Саюза і падзенне камуністычнай улады прывяло да з'яўлення незалежнай Рэспублікі Беларусь. Гэта стала нечаканасцю для большасці членаў беларуска-ўкраінскіх клубаў, якія спадзяваліся на тое, што знікненне вялікай дзяржавы - гэта часовая сітуацыя, і нават працягвалі па звычцы адзначаць дату “Вялікага Кастрычніка”. Але большасць нашчадкаў імігрантаў не абцяжарана ідэалагічнымі пастулатамі мінулага. Яны цікавяцца сваім паходжаннем, проста глядзяць на мапу свету і вызначаюць краіну, адкуль родам іх продкі. І потым дзеці і ўнукі беларусаў у Аргенціне, каб атрымаць уяўленне аб гісторыі і культуры Беларусі, звяртаюцца па дапамогу ў беларускую амбасаду, дзе знаёмяцца з неабходнай літаратурай, набываюць народнае адзенне, музычныя зборнікі і запісы песень. Нярэдка, па ілюстрацыях з беларускіх кніг нашчадкі імігрантаў робяць вышыўкі для танцавальных і сцэнічных касцюмаў, якія дэманструюць на розных этнічных фестывалях.

Постсавецкае культурнае адраджэнне ў Беларусі ўплывае на беларусаў у замежжы. Кіраўнік клуба "Дніпро” (былы клуб імя Аляксея Талстога) у горадзе Лавальоль (правінцыя Буэнас-Айрэс) Эдуард Пеннісі неаднаразова наведвау Беларусь, і пасля апошняга раза (у 2009 годзе) вырашыў заснаваць Цэнтр беларускай культуры імя Кастуся Каліноўскага: "У Беларусі я шмат даведаўся пра гэтага чалавека. Мяне ўразіла яго гісторыя, яго рысы характару. Таму і вырашыў даць Цэнтру яго імя"48. Да таго ж Э. Пеннісі звярнуў увагу на беларускія традыцыі: “Самыя цікавыя для мяне беларускія святы - гэта

\footnotetext{
47 Ibidem.

48 Н. Юшкевіч, Ag сэрgца ga сэрgца, “Звязда”, 11.08.2014.
} 
купальская ноч і Дзяды, вельмі багатыя па змесце і сімволіцы"49. Пасля такога не дзіўна сустрэць інфармацыю аб правядзенні ў клубе "Дніпро" 22 верасня 2019 года свята "Гуканне вясны". Удзельнікі мерапрыемства, сярод якіх былі і беларускія дыпламаты, распалілі вогнішча, наладзілі песні і танцы ў выкананні клубнага хору “Белавеж” і танцавальнага гуртка “вушка". Карысна і тое, што ў клубе "Дніпро" спрабуюць прыцягнуць дзяцей да вывучэння беларускай мовы. Э. Пеннісі сцвярджаў, што дзейнічаюць адпаведныя моўныя курсы, якія вядуць Аляксандра Малафей і Ніна Брадко: “Іх бацькі былі з Палесся, таму па-беларуску спадарыні Малафей і Брадко размаўляюць не вельмі чыста: адчуваецца ўплыў украінскай мовы”50. На ўзгаданым мерапрыемстве 22 верасня 2014 года была ўзнагароджана лепшая вучаніца курсаў беларускай мовы - Міля Дуцік ${ }^{51}$.

На жаль, беларуская мова сярод нашчадкаў імігрантаў у Аргенціне не распаўсюджана: у 2010 годзе аўтар гэтага артыкула наведаў правінцыі БуэнасАйрэс і Місьёнес і сустрэў толькі аднаго чалавека, які размаўляў па-беларуску. Гэта Н. Лабаноўская, якая да пераезду ў Аргенціну расла на чакры (ферме) у Парагваі ў сям'і сялян з-пад Маладзечна. Лідар Руска-беларускай супольнасці ў Місьёнесе (Colectividad Rusa Belorusa de Misiones) 3. Забчук (яе бацька К. Арцюх з-пад Баранавіч) толькі разумее беларускую мову.

У правінцы Буэнас-Айрэс нашчадкі імігрантаў захоўваюць рысы беларускасці ў клубах, і гэта праяўляецца ў наступным:

- у клубе імя Максіма Горкага 22 ліпеня 2007 года уурачыста адкрыта бібліятэка імя Якуба Коласа (гэта невялікі пакой з кніжнымі шафамі, дзе можна знайсці кнігі і на беларускай мове), таксама ў цэнтральнай зале клуба знаходзіцца культурная кампазіцыя "Максім Горкі і Янка купала";

- у клубе імя Вісарыёна Бялінскага 4 кастрычніка 2009 года імем Янкі Купалы названа зала, дзе знаходзяцца кнігі беларускага класіка, ручнікі, сувеніры;

- у клубе “Дніпро” 24 сакавіка 2010 года створаны Беларускі культурны цэнтр "Кастусь Каліноўскі", у якім прадстаўлена беларуская сімволіка, ручнікі, кнігі. Задачамі цэнтра з'яўляецца вывучэнне беларускай мовы, гісторыі і культуры;

49 Ibidem.

50 Ibidem.

${ }^{51}$ El pasado domingo diplomáticos de la Embajada de Belarús en la Argentina partiparon en el evento "Llamado de la primavera", https://www.facebook.com/belembarg [дата звароту: 20.04.2021]. 
- у клубе “Дніпро” дзейнічае Беларускі фальклорны ансамбль “Белавеж” (удзельнікі - члены Цэнтра "Кастусь Каліноўскі").

Акрамя правінцыі Буэнас-Айрэс беларуская культура прадстаўлена нашчадкамі імігрантаў на поўначы Аргенціны ў Місьёнесе: у горадзе Обэра ёсць Парк нацыянальнасцей, у якім размешчаны традыцыйныя жылыя пабудовы тых імігрантаў, якія аселі ў гэтай правінцыі. У Парку дзейнічае дом-музей мясцовай Руска-беларускай супольнасці, у якім прадстаўлены беларускія ручнікі, вышыўка, сувеніры, а таксама бюст Янкі Купалы.

Беларуская культура па-за межамі клубаў перыядычна дэманструецца на штогадовых Фестывалях імігрантаў, і асабліва актыўнымі ў гэтым выглядаюць беларусы з клуба “Усход” (горад Берыса). Нярэдка ўдзельнікі танцавальнага калектыву “Чайка" з гэтага клуба запрашаюцца на этнічныя святы ў сталіцу краіны ці ў далёкі Місьёнес. 5 студзеня 2016 года ў фейсбуку на старонцы Амбасады Беларусі ў Аргенціне з'явілася відэо з аргенцінскага тэлебачання (9 канал, праграма Tu mejor sabado): беларусы з клуба "Усход" і з клуба імя Вісарыёна Бялінскага (горад Сан-Марцін, правінцыя БуэнасАйрэс) на працягу 25 хвілін дэманстравалі тэлегледачам сваю культуру. Сусана Гаравая (Susana Horowy) з клуба імя Вісарыёна Бялінскага была ў народным строі; яна разам з кіраўніком гэтага клуба (маці якога беларуска) і з жонкай беларускага амбасадара Людмілай Козінцавай паказвала ручнікі, сурвэткі, маленькія куфэркі, вырабы з саломкі і льну, народныя стравы (дранікі). Удзельнікі ансамбля “Чайка" падчас перадачы выканалі некалькі беларускіх танцаў.

Такім чынам, беларускія імігранты ў Аргенціне мелі ўласныя культурныя асаблівасці - мову, песні, народны строй, прыхільнасць да сваёй кухні, рэлігійныя (у першую чаргу, праваслаўныя) традыцыі. Да 1991 года яны складалі колькасна невялікую этнічную групу, якая з-за адсутнасці беларускай дзяржавы была мала прыкметнай для шараговага аргенцінца. Імігранты захоўвалі этнічныя асаблівасці, развівалі сваю культуру ў прасавецкіх таварыствах і ў антысавецкім ЗБА. Нашчадкі імігрантаў хутка аргенцінізаваліся, іх беларуская ідэнтыфікацыя стала нетрывалая. Значныя змены адбыліся пасля 1991 года, калі незалежнасць набыла Рэспубліка Беларусь. У цяперашні момант нашчадкі імігрантаў, з аднаго боку, застаюцца прыхільнымі ідэі ўсходнеславянскага братэрства, з іншага хутка авалодалі беларускай нацыянальнай ідэяй, з яе пантэонам герояў і інтэрпрэтацыяй мінулага. Апошняе з'яўляецца вынікам не захавання запаветаў продкаў, а наступствам дзяржаўнай самастойнасці Беларусі і працы яе прадстаўнікоў у беларускім замежжы. Пры гэтым, дзеля ілюстрацыі сваёй адметнасці ў Аргенціне нашчадкі імігрантаў выкарыстоўваюць не 
толькі дзяржаўныя сімвалы Рэспублікі Беларусь, але і элементы культуры сваіх бацькоў і дзядоў. У выніку, беларуская культура стала тым стрыжнем, які яднае ўсіх імігрантаў-беларусаў і іх нашчадкаў, жадаючых атаясамляць сябе з Беларуссю.

\section{Бібліяграфія}

Антонава Т., Аргенцінскія сустрэчы Мікалая Скорыкава. Душа рвецца за марай, "Голас Радзімы”, 28.04.1988, с. 7 [Antonava T., Argencinskiâ sustrèčy Mikalaâ Skorykava. Duša rvecca za maraj, "Golas Radzìmy", 28.04.1988, s. 7].

БДАМЛіМ, ф. 3, воп. 1, спр. 48, л. 44-45 [BDAMLì, f. 3, vop. 1, spr. 48, I. 44-45].

Беларускі дзяржаўны архіў-музей літаратуры і мастацтва [далей: БДАМЛіМ], ф. 3, воп. 1, спр. 44: Ліст Ф. Паўлоўскага ад 22.09.1935 г., л. 6 об. [Belaruskì dzâržaǔny arhì̌muzej litaratury ì mastactva [dalej: BDAMLì], f. 3, vop. 1, spr. 44: Lìst F. Paǔloǔskaga ad 22.09.1935 g., l. 6 ob.].

Белорусская эмиграция в Аргентине и ее Культ-Организации, "Белорусский иллюстрированный календарь на 1943 г." 1942, с. 80 [Belorusskaâ èmigraciâ v Argentine i ee Kul't-Organizacii, "Belorusskij illûstrirovannyj kalendar' na 1943 g." 1942, s. 80-82].

Бойков М., Козырь или повесть о том, как Петрусь Лукашук езgил на роgину, "Наша страна", 7.04.1955, с. 5 [Bojkov M., Kozyr' ili povest' o tom, kak Petrus' Lukašuk ezdil na rodinu, "Naša strana", 7.04.1955, s. 5].

Бошко М., Театр, “Белорусский иллюстрированный календарь на 1941 г.” 1940, с. 155-159 [Boško M., Teatr, "Belorusskij illûstrirovannyj kalendar' na 1941 g." 1940, s. 155-159].

Выдавецтва, Праgмова, "Белорусский иллюстрированный календарь на 1943 г." 1942, с. 4 [Vydavectva, Pradmova, "Belorusskij illûstrirovannyj kalendar' na 1943 g." 1942, s. 4].

Коваль В., Узаемасувязі беларускай і ўкраінскай gыяспар у міжваенны перыяg, Мінск 2012 [Koval' V., Uzaemasuvâzì belaruskaj ì ǔkraìnskaj dyâspar u mižvaenny peryâd, Mìnsk 2012].

Котовський А., На берегах Ла-Плати, Львів 1988 [Kotovs'kij A., Na beregah La-Plati, Lviv 1988].

Мерляк К., Дзейнасць Кастуся Мерляка на Эміграцыі, Нью Ёрк 1992 [Merlâk K., Dzejnasc' Kastusâ Merlâka na Ėmigracyì, Nû Ërk 1992].

Нацыянальны архіў Рэспублікі Беларусь [далей: НАРБ], ф. 914, воп. 1, спр. 18, л. 120121, 133; воп. 2, спр. 32 с, л. 2; воп. 3, спр. 121, л. 26 [Nacyânal'ny arhiǔ Rèspublikì Belarus' [dalej: NARB], f. 914, vop. 1, spr. 18, I. 120-121, 133; vop. 2, spr. 32 s, I. 2; vop. 3, spr. 121, I. 26].

НАРБ, ф. 1267, воп. 3, спр. 90, л. 1, 7 [NARB, f. 1267, vop. 3, spr. 90, I. 1, 7].

Таварыства "Радзіма”, [Верш С. Самасюка ад 24.12.1934] [Tavarystva "Radzìma”, [Verš S. Samasûka ad 24.12.1934]]. 
Таварыства “Радзіма", [Ліст С. Самасюка ад 7.04.1966] [Tavarystva "Radzìma”, [Lìst S. Samasûka ad 7.04.1966]].

Цяўлоўскі Э., Аргентына - Буэнос Айрэс, "Божым шляхам" 1968, № 3, c. 10-11 [Câŭloǔskì È., Argentyna - Buènos Ajrès, "Božym šlâham" 1968, nr 3, s. 10-11].

Цяўлоўскі Э., Беларусы ў Бэрыса (Аргентына), "Беларус", люты 1982, с. 3 [Câǔloǔskì È., Belarusy ǔ Bèrysa (Argentyna), "Belarus», lûty 1982, s. 3].

Цяўлоўскі Э., На фестывалі ў Бэрыса, "Беларус" 1982, лістапад-сьнежань [Câǔloǔskì È., Na festyvali ǔ Bèrysa, "Belarus", listapad-s'nežan' 1982].

Цяўлоўскі Э., “Пайзанас" з Бэрыса, “Беларус", травень 1979 [Câǔloǔskì Ѐ., "Pajzanas” z Bèrysa, "Belarus", traven' 1979].

шабельцаў С., Беларусы ў Аргенціне: грамаgская gзейнасць і рээміграцыя ў СССР (1930-1960-я г.). Зборнік gакументаў і ўспамінаў, Мінск 2009 [Šabel'caǔ S., Belarusy ǔ Argencine: gramadskaâ dzejnasc' ì rèèmigracyâ ǔ SSSR (1930-1960-â g.). Zbornik dakumentaǔ i ǔspaminaǔ, Mìnsk 2009].

Шабельцев С., Иммигранты-чакареро из II Речи Посполитой в Аргентине и Парагвае. Воспоминания белорусов и украинцев, Минск 2011 [Šabelcev S., Immigranty-čakarero iz II Reči Pospolitoj v Argentine i Paragvae. Vospominaniâ belorusov i ukraincev, Minsk 2011].

Э.Ц., Як аргентынскія беларусы сьвяткуюць каляgы, “Беларус", студзень 1965, с. 6 [Ё.С., Âk argentynskiâ belarusy s'vâtkuûc' kalâdy, "Belarus", studzen' 1965, s. 6].

Юшкевіч Н., Ag сэрgца ga сэрgца, “Звязда”, 11.08.2014 [Ûškevič N., Ad sèrdca da sèrdca, "Zvâzda", 11.08.2014].

Arciuch Z., Mis raíces. La tierra de mis padres, Obera 2016.

Bielorrusia y los bielorrusos en la República Argentina, Buenos-Aires 1953.

El pasado domingo diplomáticos de la Embajada de Belarús en la Argentina partiparon en el evento "Llamado de la primavera", https://www.facebook.com/belembarg [дата звароту [data zvarotu]: 20.04.2021].

Partacz C., Ukraińcy w Polskich Siłach Zbrojnych w czasie II wojny światowej, [y [u]:] Polska Ukraina: trudne pytania, t. 9, Warszawa 2002, c. [s.] 89-129. 


\section{Język białoruski - stan obecny i perspektywy}

\section{The Belarusian language - current state and prospects}

The article examines the current state of the Belarusian language and the non-linguistic factors influencing its current situation, e.g. linguistic prestige, linguistic shame, stereotyping of the language. Also highlighted are subjective and emotional factors that influence negative or positive attitudes towards the Belarusian language depending on current social events.

Ke y w ord s: Belarusian language, linguistic prestige, linguistic shame, stereotyping of language, language revival

Język białoruski - stan obecny i perspektywy

W artykule jest badany obecny stan języka białoruskiego i czynniki pozajęzykowe wpływające na jego obecną sytuację, np. prestiż językowy, wstyd językowy czy stereotypizacja języka. Podkreślane są czynniki subiektywne i emocjonalne, które wpływają na nastawienie negatywne lub pozytywne do języka białoruskiego w zależności od bieżących wydarzeń społecznych.

Słowa klu c z ow e: język białoruski, prestiż językowy, wstyd językowy, stereotypizacja języka, odrodzenie języka

Język białoruski można analizować albo z pozycji neutralnej (obiektywnej, naukowej), biorąc pod uwagę tylko czynniki językowe, albo z pozycji nieneutralnej, subiektywnej, czyli emocjonalnej (pozytywnej lub negatywnej wobec języka), która zakłada opieranie się na czynnikach pozajęzykowych (politycznych, psychologicznych itd.). Protesty na Białorusi mające miejsce po wyborach prezydenckich z 9 sierpnia 2020 r. bardzo zaogniły emocje także wobec języka białoruskiego, czyniąc z niego symbol (nośnik) konkretnego światopoglądu moralnego czy politycznego. W niniejszym artykule główna uwaga zostanie skupiona właśnie na czynnikach pozajęzykowych w kontekście ostatniego 
przebudzenia narodowego. Czynniki te przejawiają się nie tylko w publicystyce i w komentarzach internetowych, lecz także w tekstach opublikowanych w pismach (wydawałoby się) naukowych.

\section{Wstyd językowy}

Oprócz czynników historyczno-politycznych mających wpływ na marginalizację języka białoruskiego na rzecz języka rosyjskiego miały wpływ także inne czynniki pozajęzykowe, takie jak prestiż językowy, stereotypizacja języka również pod wpływem silnej propagandy (np. traktowanie białoruskiego jako języka kołchozów czy zwariowanych polityków opozycyjnych - upolitycznienie kwestii językowych/traktowanie ich jako przejaw światopoglądu), wstyd językowy?', kłamstwa językowe (np. dzielenie języków na lepsze i gorsze).

Pod wpływem tych i innych czynników o Białorusinach mówiło się, że „milczą po białorusku”2. My w tym kontekście używaliśmy określeń: „język białoruski jako cudzy”, „wewnętrzna emigracja językowa”", a obecnie użylibyśmy także sformułowań: „brak odwagi językowej” czy wręcz „lęk językowy”, wynikający z chęci uzyskania korzyści zawodowych, lepszego statusu społecznego lub po prostu przetrwania w sytuacji dyskryminacji językowej.

1 Wstyd językowy to proces marginalizacji, nielojalności, poniżania, postępującej zarówno indywidualnej, jak i zbiorowej rezygnacji z języka białoruskiego na rzecz rosyjskiego w warunkach dominacji języka rosyjskiego, zob. У. Іваноў, Моўны сорам беларусаў (сацыялінгвістычны аналіз), „Acta Albaruthenica” 2020, t. 20, s. 171.

2 Stwierdzenie z wiersza białoruskiego poety Uładzimira Arłoua, zob. R. Kaleta, Polsko-białoruska lapsologia glottodydaktyczna, Warszawa 2015, s. 20.

3 Zob. P. Калета, Белорусский язык как (ино)странный, чужой и роgной в начале XXI века, [w:] Беларуская мова ў XXI стагоggзі: асноўныя тэнgэнцыі развіцця (ga 80-гоggзя акаgэміка А.І. Паялужнага). Зборнік матэрыялаў Міжнароднай навуковай канферэнцыі, Мінск, 28-29 кастрычніка 2015 гoga, red. Л.А. Ліхадзіеўская і in., Мінск 2015, s. 142-149; R. Kaleta, O niektórych tendencjach w funkcjonowaniu współczesnej białoruszczyzny, [w:] Białoruś w dyskursie naukowym. Lingwistyka, socjologia, politologia = Беларусь у навуковым gыскурсе. Лінгвістыка, сацыялогія, паліталогія = Belarus in Scientific Discourse. Linguistics, Sociology, Political Science, red. R. Kaleta, Warszawa 2017, s. 395 i nast.

4 Zob. R. Kaleta, Błędologia w glottodydaktyce białorutenistycznej, Warszawa 2018, s. 62. 


\section{Upolitycznianie, ideologizowanie i dyskryminowanie języka białoruskiego}

Za używanie języka białoruskiego w różnych okresach historii można było doświadczyć szykan lub być skazanym na gorszy status społeczny. Widać to także współcześnie, szczególnie w kontekście masowych akcji protestacyjnych mających miejsce na Białorusi po wyborach prezydenckich uznanych przez opozycję i Zachód za sfałszowane. Media donosiły, że pod pretekstem zarzutu o łamanie ustawy o zgromadzeniach publicznych zatrzymano grupę emerytów na stacji kolejowej Mińsk Północny z powodu lektury w elektryczce białoruskiej literatury, w tym klasyka Janka Kupały (błrus. Янка Купала)5.

Tego typu szykany potwierdzają, że przedstawiciele władzy boją się języka białoruskiego (czyli przejawiają białorusofobię) i często jego używanie w przestrzeni publicznej jest określane mianem nacjonalizmu, podczas gdy używanie języka rosyjskiego w Rosji, polskiego w Polsce, czeskiego w Czechach itd. nie jest za takie uważane. Na Białorusi jednak nawet oficjalne środowiska naukowe (choć nielingwistyczne) z Akademii Nauk w osobach jej szefa Uładzimira Husakoua (błrus. Уладзімер Гусакоў) і sekretarza Aleksandra Kawaleni (błrus. Аляксандар Каваленя) w artykule z 2020 r. (szokującym zagraniczną opinię naukową) popularyzują ideę dwujęzyczności państwowej, w której język rosyjski ma jednak rolą wiodącą. Proces rusyfikacji nazwany jest ubogacaniem białoruskiej kultury i gwarantem rozwoju:

Процесс взаимного влияния различных культур, при котором все или часть представителей одной культуры перенимают нормы, ценности и традиции другой, получил название аккультурации. Это очень обогащает, имея одну культуру, народ дополняет ее другой. Ярким примером этому служит белорусско-русский билингвизм, где самобытный и глубоко народный белорусский ярко дополняется гармоничным русским 6 . [...] Представляется, что объективное существование в белорусском языковом пространстве русского языка, как и других европейских

5 Zob. Улаgы agказалі: чытаньне беларускіх пісьменьнікаў не забаронена, але можа парушыць закон, https://svaboda.azureedge.net/a/31162195.html [dostęp: 31.05.2021]. Przejawów dyskryminacji językowej w historii Białorusi było i jest bardzo dużo, o czym wspomina w swym artykule: У. Іваноў, Моўны сорам беларусаў.

${ }^{6}$ Zob. В.Г. Гусаков, А.А. Коваленя, Белорусско-русское двуязычие - иссторически сложившаяся gуховно-культурная ценность нароga, „Доклады Национальной академии наук Беларуси" 2020, т. 64, № 4, s. 510, https://doklady.belnauka.by/jour/ article/view/908/905\# [dostęp: 31.05.2021]. 
языков, будет благотворно способствовать расширению мировоззренческого и интеллектуального уровня белорусов. Этот непреходящий гуманистический посыл, являясь объективным следствием и закономерностью общественного развития, несомненно, будет важным фактором, способствующим социальнокультурному, экономическому и научно-техническому развитию Беларусиㄱ.

Tymczasem o ubogacaniu kultury mowa być może tylko wtedy, gdy nie ma dyskryminacji językowej języka narodowego, kiedy w praktyce (a nie tylko na papierze) zagwarantowany i realizowany jest jego rozwój. Inaczej to „ubogacanie kultury" jest czystą asymilacją.

Autorzy przytaczanego artykułu w krótkim zdaniu doceniają bliżej nieokreślone: „serdeczność” (ros. душевность), „gibkość” (ros. гибкость) i „zdolność adaptacji" (adaptowalność, ros. адаптивность) języka rosyjskiego ${ }^{8}$. Dopiero w podsumowaniu tekstu pojawia się krótki akapit na korzyść języka białoruskiego:

Разумеется, равнодушие к родному языку порождает равнодушие к прошлому и настоящему белорусского народа, а значит, и к будущему нашей страны. В связи с этим важно подчеркнуть, что белорусский язык играл и играет исключительно важную роль в отражении особенностей национально-духовной жизни, мировоззрения и менталитета народа, являясь главным средством сохранения и развития белорусской народной культуры и традиций․

7 „Proces wzajemnego oddziaływania różnych kultur, w którym całość lub część jednej kultury przyjmuje normy, wartości i tradycje drugiej, nazywamy akulturacją. To bardzo ubogaca, gdy mając jedną kulturę, naród uzupełnia ją inną. Wyrazistym tego przykładem jest dwujęzyczność białorusko-rosyjska, gdzie samodzielny i głęboko ludowy język białoruski jest żywo uzupełniany przez harmonijny język rosyjski. [...] Wydaje się, że obiektywne istnienie języka rosyjskiego w białoruskiej przestrzeni językowej, podobnie jak innych języków europejskich, będzie korzystne dla poszerzenia światopoglądu i poziomu intelektualnego Białorusinów. To trwałe humanistyczne przesłanie, będące obiektywną konsekwencją i prawidłowością rozwoju społecznego, będzie niewątpliwie ważnym czynnikiem przyczyniającym się do społeczno-kulturalnego, gospodarczego, naukowego i technologicznego rozwoju Białorusi" [tłum. na potrzeby własne - R.K.]. Zob. ibidem, s. 511.

8 Ibidem, s. 510.

9 „Oczywiście, obojętność wobec języka ojczystego rodzi obojętność wobec przeszłości i teraźniejszości narodu białoruskiego, a tym samym wobec przyszłości naszego kraju. W związku z tym należy podkreślić, że język białoruski odgrywał i nadal odgrywa niezwykle ważną rolę w odzwierciedlaniu osobliwości życia narodowego i duchowego, światopoglądu i mentalności narodu, będąc głównym środkiem zachowania i rozwoju białoruskiej kultury ludowej i tradycji" [tłum. na potrzeby własne - R.K.]. Zob. ibidem, s. 511. 
Cała uwaga w artykule koncentruje się na wychwalaniu języka rosyjskiego, który ma przecież świetne warunki do rozwoju w Rosji, gdzie nic mu nie zagraża.

Полагаем, сравнивая русский язык как часть многообразной русской культуры с языками других стран и народов по звучанию, восприятию, ощущению, отражению событий и другим качествам, следует в первую очередь признать, что нет другого такого языка в мире, который так бы точно, полно и образно передавал суть любого «предмета» как в разговорной речи, так и в письменном изложении. Наличие известного количества падежей, склонений и окончаний слов позволяет это делать почти с ювелирной точностью. Он очень удобен по произношению, красив по звучанию, насыщен по смыслу передаваемой и воспринимаемой информации. Включает достоинства всех других языков мира. [...] Наряду с достоинствами, он лишен недостатков многих известных языков других стран и народов. Так, русский язык не приемлет резкости и напористости английского, скороговорки и громкости итальянского, спешности и неполной выразительности французского, маршевости немецкого, «пшеканья» польского ${ }^{10}$.

Jest to więc popularyzowanie tezy, że są języki lepsze i gorsze. Co więcej, jest to sztuczne konfrontowanie języków na zasadzie przeciwstawiania sobie reprezentujących je państw. Autorzy artykułu utożsamiają język z danym państwem i jego polityką. Poprzez porównanie języków i ich ocenę mającą charakter poniżenia daje się niejako prztyczka w nos polityce danych krajów. Tymczasem nie ma języków lepszych czy gorszych, lecz są bardziej i mniej używane. Na to zwracał uwagę już Franciszek Bohuszewicz (o pseudonimie Maciej Buraczok) w przedmowie do tomiku swych wierszy Dudka białoruska: „mowa naszaja jość takajaż ludzkaja i panskaja jak i francuzskaja, albo niamieckaja, albo i inszaja

10 „Uważamy, że porównując język rosyjski jako część różnorodnej kultury rosyjskiej z językami innych krajów i narodów pod względem brzmienia, postrzegania, odczuwania, odzwierciedlania zdarzeń i innych cech, należy przede wszystkim przyznać, że nie ma na świecie drugiego języka, który tak dokładnie, w pełni i obrazowo oddawałby istotę dowolnego «przedmiotu» zarówno w mowie mówionej, jak i w prezentacji pisemnej. Obecność znanej liczby przypadków, deklinacji i końcówek wyrazów pozwala na to z niemalże jubilerską precyzją. Rosyjski jest bardzo łatwy w wymowie, piękny w brzmieniu, bogaty w sens przekazywanych i odbieranych informacji. Zawiera w sobie zalety wszystkich innych języków świata. [...] Oprócz swoich zalet nie ma on również wad wielu znanych języków innych krajów i narodów. Na przykład, język rosyjski nie akceptuje srogości i stanowczości języka angielskiego, szybkości i głośności języka włoskiego, pośpiechu i niepełnej ekspresji języka francuskiego, marszowości języka niemieckiego, "przekania» języka polskiego" [tłum. na potrzeby własne - R.K.]. Zob. ibidem. 
jakaja [...] Nasza mowa dla nas swiataja, bo jana nam ad Boha danaja, jak i druhim dobrym ludcam"11.

Dalsze uwagi na temat języka rosyjskiego nie noszą charakteru naukowego, ale polityczno-propagandowy i ideologizujący, a nawet otaczają kultem język rosyjski jako język prawdy i ,język dany od Boga”:

Он не зацикливается на произношении каких-то отдельных гласных и согласных и бесконечном повторении однообразных окончаний. Это язык универсального использования и вездесущей пригодности. На нем одинаково ценно отражаются как исторические и хронологические сведения, так и жизнеутверждающие народные повествования, романы и рассказы. Он хорош и для литераторов, и для ученых, и для театральных деятелей, и для инженеров, и для бытовых целей. Может об этом и не стоит, но на русском языке наиболее сочно звучит даже ненормативная лексика, так называемый слэнг, которым пользуется весь мир. А какие прекрасные выразительные на русском языке сказки и предания, стихи и песни. Мощные и раздольные, всепоглощающие и уносящие с собой. Это язык талантов и победителей, народных чаяний и устремлений. Сила и совершенство русского языка, как и русского народа, во всем -и в форме, и в содержании. Разве можно не любить русский язык? Если это язык правды и истины. Именно русскому народу начертано быть первопроходцем и провидцем мирового развития. Надо быть лишенным элементарной культуры и безумцем, чтобы отрицать русский язык. Если это язык дороги к Храму. Только сильному народу мог быть дан такой язык. Ведь каждому дается по его заслугам².

11 M. Buraczok, Dudka białoruska, Kraków 1891, s. 3-4: „język nasz jest taki sam ludzki i pański jak język francuski albo niemiecki, albo i inny jakiś [...] Nasz język jest dla nas święty, bo jest nam dany od Boga, jak i innym dobrym ludziom" [tłum. na potrzeby własne - R.K.].

12 В.Г. Гусаков, А.А. Коваленя, Белорусско-русское gвуязычие, s. 510. „Nie ma w nim nacisku na wymowę poszczególnych samogłosek i spółgłosek oraz niekończącego się powtarzania monotonnych końcówek. Jest to język o uniwersalnym zastosowaniu i wszechobecnej użyteczności. W nim tak samo wartościowo przedstawiane są zarówno informacje historyczne i chronologiczne, jak i podtrzymujące życie narracje ludowe, powieści i opowiadania. Rosyjski nadaje się zarówno dla pisarzy, naukowców, działaczy teatralnych, inżynierów, jak i dla załatwiania spraw codziennych. Może nie warto o tym wspominać, ale po rosyjsku najbardziej dosadnie brzmi nawet leksyka nienormatywna, czyli tzw. slang, używany na całym świecie. A jakie piękne i ekspresyjne są baśnie i legendy, wiersze i pieśni w języku rosyjskim. Potężne i przestronne, wszechogarniające i pochłaniające. Jest to język talentów i zwycięzców, narodowych nadziei i aspiracji. Siła i doskonałość języka rosyjskiego, jak też narodu rosyjskiego, przejawia się we wszystkim: i w formie, i w treści. Czy można nie kochać języka rosyjskiego? Jeśli jest to język prawdy. To właśnie narodowi rosyjskiemu przeznaczone jest być pionierem i wizjonerem światowego rozwoju. Trzeba być 
Przeciwko takiemu nienaukowemu poniżaniu jednych języków i wywyższaniu innych protestowali polscy białoruteniści (Instytut Slawistyki Polskiej Akademii Nauk wystosował specjalne pismo do kolegów z Narodowej Akademii Nauk Białorusi), a także niezależni białoruscy językoznawcy, jak Winczuk Wiaczorka (błrus. Вінцук Вячорка) ${ }^{13}$. Niestety trudno oprzeć się wrażeniu, że artykuł wpisuje się w akcję propagandową popularyzującą konkretny pogląd coraz częściej istniejący w ostatnich latach w rosyjskiej przestrzeni medialnej. Reprezentujący ten pogląd politolodzy i analitycy twierdzą, że naród i język białoruski to sztuczne twory wymyślone albo przez bolszewików, albo przez Polaków w celu zburzenia ogólnorosyjskiej jedności. Samodzielności istnienia języka białoruskiego dowodzą jednak białoruscy lingwiści z prof. Hienadziem Cuchunem (błrus. Генадзь Цыхун) z Akademii Nauk Białorusi na czele ${ }^{14}$.

Upolitycznienie języka białoruskiego wciąż jest bardzo silne. Już jesienią 2020 r. zatrzymanych protestujących, którzy posługiwali się językiem białoruskim, funkcjonariusze oznaczali farbą, żeby w więzieniach obchodzono się z nimi o wiele gorzej niż z pozostałymi aresztowanymi. Media donosiły o przedstawicielce inicjatywy Warunki dla języka (błrus. Умовы gля мовы) Alinie Nahornej (błrus. Аліна Нагорная) ${ }^{15}$, która zebrała środki na druk książki Мова 404 $\left(\right.$ Język 404) ${ }^{16}$. Jest w niej 100 opowieści o tym, jak na Białorusi za język białoruski można być znieważonym, a nawet pobitym, m.in. historia artysty, którego bito 8 godzin w więzieniu, historia emerytki, której nie obsłużono w banku czy śpiewaczki, którą z powodu używania języka białoruskiego uznano za Ukrainkę ${ }^{17}$.

pozbawionym podstawowej kultury i obłąkanym, żeby negować język rosyjski. Jeśli to jest też język drogi do Świątyni. Tylko silny naród mógł otrzymać taki język. W końcu każdy otrzymuje według swoich zasług" [tłum. na potrzeby własne - R.K.].

13 В. Вячорка, Нашто кіраўніцтва Акаgэміі навук Беларусі прыніжае беларускую мову?, https://svaboda.azureedge.net/a/svintus-grandiosus-immortalis-et-aeternus/30890969.html [dostęp: 31.05.2021].

14 Zob. С. Абламейка, Прафэсар Генаgзь Цыхун: Беларуская мова існуе шмат стагоgзьязяў, https://svaboda.azureedge.net/a/28189620.html [dostęp: 31.05.2021].

15 Autorka we współautorstwie z prawnikiem Igorem Słuczkiem (błrus. Ігар Случак) wydała w 2018 r. także poradnik obrony praw językowych pt. Абаронім мову, a w 2019 r. zorganizowała wydanie książki dla dzieci Кошык вожыка, którą przekazywano instytucjom, gdzie prawie nie ma literatury dziecięcej w języku białoruskim, zob. На кнігу „Мова 404” пра gыскрымінацыю за беларускую мову сабралі неабхоgную суму, https://svaboda. azureedge.net/a/31151140.html [dostęp: 31.05.2021].

16 Ibidem.

17 Podobną księgę, pokazującą rusyfikację w różnych warstwach społeczeństwa, wydało 20 lat wcześniej Towarzystwo Języka Białoruskiego - Аняменне, з хронікі знішчэння 
Opisane w książce historie pokazują dyskryminację nie tylko samego języka, lecz także osoby ze względu na język, którym ona się posługuje, oraz łamanie konstytucji Białorusi gwarantującej równy status obydwu językom państwowym. Jednak nie o sam język tu chodzi, lecz także o wartości, które on symbolizuje. Władza nie chce silnej białoruskiej świadomości narodowej prowadzącej do wolności demokratycznej. Dlatego zamykane są media białoruskojęzyczne, np. portal tut.by, a z kiosków Белсаюздруку są usuwane białoruskie lub dwujęzyczne wydania jak „Народная Воля” сzy „Наша гісторыя”. Likwidowane są także sklepy sprzedające towary z historyczną symboliką narodową. Posługiwanie się flagą biało-czerwono-białą i godłem Pogoń są zabronione, grozi za nie kara więzienia, konfiskata samochodu, wybicie szyby i inne szykany ${ }^{18}$.

\section{Powrót do języka}

Fala protestów na Białorusi trwająca po wyborach prezydenckich z 9 sierpnia 2020 r. doprowadziła do odrodzenia białoruskiej świadomości nie tylko narodowej, lecz także językowej. Zatem obok swoistej „konwersji narodowej” (określenie Antoniny Kłoskowskiej) mamy do czynienia ze swoistą konwersją językową, czyli powracaniem do języka ojczystego, który w warunkach republik postsowieckich (czyli także na Białorusi) może być różnie definiowany, np. jako język narodowości, do której się należy, jako język przodków (rodziców, dziadków), a także (choć niekoniecznie) jako język, którym dana osoba posługuje się najczęściej, w którym myśli i swobodnie rozmawia ${ }^{19}$. W przypadku Białorusi trzeba by dodać jeszcze jedno kryterium: język ojczysty to ten, który świadomie wybieram jako ojczysty i w którym zaczynam się komunikować. Chodzi tu też o powrót do języka przodków, nieużywanego na co dzień z racji wszechobecnej rusyfikacji życia codziennego (obejmującej media, urzędy, edukację itd.).

Obecnie widać tendencję odwrotną do wspomnianych wcześniej „wstydu językowego” czy „wewnętrznej emigracji językowej”. Trend ten można nazwać roboczo „odwagą językową”, „powrotem z wewnętrznej emigracji językowej”, wspomnianą „konwersją językową”, „przejściem od języka białoruskiego jako

беларускай мовы, Вільня 2000, https://knihi.com/none/Aniamiennie_Z_kroniki_zniscennia_bielaruskaj_movy.html.

18 Zob. C. Абламейка, Беларуская мова выхоgзіць на пярэgні плян супраціву, https://svabod1.azureedge.net/a/31139605.html [dostęp: 31.05.2021].

19 Por. T.A. Olszański, Problem językowy na Ukrainie. Próba nowego spojrzenia, „Prace OSW" 2012, nr 40, s. 14. 
cudzego do języka białoruskiego jako ojczystego"20 itd., wynikających zapewne z mocniejszej świadomości narodowej. W literaturze mówi się też o odzyskiwaniu języka (błrus. адноўленая мова), czyli powrocie do języka przodków²1.

Media podają informacje o takich oddolnych inicjatywach powracania do języka białoruskiego. Na początku 2021 r. białoruscy lekarze stworzyli inicjatywę MovaMed mającą na celu poszerzenie używania białoruszczyzny w medycynie przywrócenie do użytku terminologii medycznej, której środowisko będzie się uczyć i używać w kontaktach z innymi lekarzami i pacjentami. Kolejny etap to wprowadzenie białoruskiej terminologii medycznej do nauki i dyskusji lekarskich ${ }^{22}$.

\section{Język białoruski jako mowa rewolucji białoruskiej}

Rewolucja białoruska ma swój wpływ także na język białoruski. Innowacje są badane przez białoruskich naukowców, którzy musieli wyjechać z Białorusi, np. dr Julię Gurską (błrus. Юлія Гурская), która opracowuje onomastykon rewolucji białoruskiej.

W komunikatorze Telegram funkcjonuje kanał poświęcony plakatom protestacyjnym, dla których typowy jest komizm językowy - gra słów o podwójnym sensie. Plakaty są pisane po rosyjsku, po białorusku, a także celowo mieszanką rosyjsko-białoruską zwaną popularnie „trasianką”. Język plakatów protestacyjnych analizuje w swej pracy licencjackiej przygotowywanej w Katedrze Białorutenistyki Uniwersytetu Warszawskiego (UW) Ksenia Voran. Z druku wyszedł już album poświęcony białoruskim plakatom protestacyjnym ${ }^{23}$.

Prawdopodobnie coraz więcej badaczy będzie zajmować się tą tematyką, aby pokazać, jak zmiany świadomości i zmiany społeczne są odzwierciedlane w zmianach językowych, np. obok nazwy „Białoruś” funkcjonuje nazwa „nowa Białoruś" dla oznaczenia środowiska prowolnościowego. Do tego tematu nawiązywać będą nie tylko lingwiści, lecz także dziennikarze i pisarze, np. noblistka Swiatłana Aleksijewicz (błrus. Святлана Алексіевіч) zapowiedziała napisanie książki o rewolucji białoruskiej.

Wyrazem odrodzenia świadomości narodowej i dążenia do wolności jest też postulat zapisywania nazw narodowości w języku białoruskim wielką literą, jak to jest w większości języków europejskich (z wyjątkiem języków wschodnio-

\footnotetext{
20 Zob. R. Kaleta, O niektórych tendencjach, s. 400.

21 Zob. R. Kaleta, Błędologia w glottodydaktyce.

22 Zob. C. Абламейка, Беларуская мова выхоgзіць.

23 Zob. А. Пірс, Я выхожу, https://svaboda.azureedge.net/a/31195495.html.
} 
słowiańskich i bułgarskiego). Do tej pory, podobnie jak w języku rosyjskim, nazwy te pisano małą literą. Pod wpływem rewolucji godności 2020 roku powstał pomysł, żeby nazwę „Białorusin” (błrus. беларус) pisać wielką literą²4. Do tej pory takie formy można było spotkać w wydaniach emigracyjnych zwykle pod wpływem języków zachodnich, a także w języku Polaków uczących się języka białoruskiego, którzy pod wpływem polszczyzny tego typu formy pisali wielką literą ${ }^{25}$.

Przedstawiciele władzy widziani są jako sprzymierzeńcy okupacyjnego reżimu wspieranego przez Rosję. Naród nie dysponuje wojskiem i ulega nieludzkim torturom, więc jedyną formą oporu i sprzeciwu jest bardzo szybkie przejście na język białoruski ${ }^{26}$. W tym kontekście staje się on nie tylko symbolem idei narodowej, lecz także narzędziem walki o zachowanie tej idei i wyrazem partyzanckiego protestu i wyboru politycznego. Dziennikarz Radia Svaboda Siarhiej Abłamiejka (błrus. Сяргей Абламейка) bardzo wyraźnie określa białoruszczyznę jako broń polityczną:

Беларуская мова - гэта мяккая сіла і ўнівэрсальны сродак барацьбы з дыктатурай. Дэмакратыя ў Беларусі - гэта беларуская мова. Незалежнасьць Беларусі - гэта беларуская мова. [...] Будучыня Беларусі залежыць ад беларускай мовы ${ }^{27}$.

W takim politycznym kontekście i momencie - dziejowego być albo nie być - język białoruski znów stał się dla Białorusinów językiem ojczystym, czy raczej - matczynym. Jest ostatnim autorytetem, ostatnim bastionem walki o niepodległość. Z taką bronią językową władzom jest już trudniej walczyć, bo wymagałoby to całkowitego zakazu używania języka białoruskiego, czyli też rozmawiania z bliskimi w tym języku, śpiewania piosenek i czytania literatury. Chociaż zabronić się tego nie da, to jednak władze często gnębią użytkowników języka białoruskiego i literatury białoruskiej pod pozorem łamania innych przepisów, np. dotyczących zgromadzeń publicznych w myśl zasady z czasów stalinowskich, że paragraf się zawsze znajdzie.

24 Zob. C. Абламейка, Hagышоў час пісаць слова „Беларус” зь вялікай літары, https://svaboda.azureedge.net/a/30890971.html [dostęp: 31.05.2021].

${ }_{25} \mathrm{Na}$ zajęciach z języka polskiego dla Białorusinów zwracałem kiedyś uwagę, że po polsku nazwy narodowości piszemy dużą literą i wtedy jeden Białorusin spytał: „Białorusina też?".

26 Zob. C. Абламейка, Беларуская мова выхоgзіць.

27 „Język białoruski to miękka siła i uniwersalny środek walki z dyktaturą. Demokracja na Białorusi to język białoruski. Niepodległość Białorusi to język białoruski. [...] Przyszłość Białorusi zależy od języka białoruskiego" [tłum. na potrzeby własne - R.K.]. Zob. С. Абламейка, Беларуская мова выхоgзіць. 
Według wspomnianego publicysty:

За лёс беларускай мовы можна не турбавацца. Беларусы яе любяць, адчуваюць калектыўны сорам за яе бядотнае становішча і масава выказваюцца за яе адраджэньне ${ }^{28}$.

Podaje on jako dowód cytaty z wypowiedzi uczestników akcji demonstracyjnych:

1. „Выбачайце, я буду па-расейску, але беларуская мова прыгожая, я яе люблю...”29;

2. „Я пачну на роднай мове, але фармуляваць думкі мне лягчэй па-расейску. Вельмі прашу мне прабачыць..."30;

3. „Наша мова самая прыгожая, я на жаль мала на ёй размаўляю...”31;

4. „Бачыце, я не зусім упэўнена гавару на роднай мове...”32;

5. „Мы адродзім родную мову, яна клясная...”33.

Podobne zjawisko można zaobserwować wśród przedstawicieli powyborczej fali imigracji białoruskiej do Polski. W Warszawie jest coraz więcej młodych Białorusinów, którzy zaczynają świadomie wracać do języka białoruskiego. $\mathrm{Na}$ studia w Katedrze Białorutenistyki UW coraz częściej uczęszczają Białorusini chcący wspomóc swoje przejście na język białoruski. Zdarza się, że na pierwszych zajęciach dosłownie przepraszają wykładowcę, że nie mogą odpowiedzieć mu po białorusku, a tylko po rosyjsku lub polsku, ale już po kilku tygodniach uczestnictwa w zajęciach mówią już prawie wyłącznie po białorusku, dopytując o pojedyncze słowa, których im w danym momencie brakuje.

28 „O los języka białoruskiego można się nie martwić. Białorusini go kochają, czują zbiorowy wstyd z powodu jego biednego stanu i masowo opowiadają się za jego odrodzeniem" [tłum. na potrzeby własne - R.K.]. Zob. C. Абламейка, Нацыя беларусаў закончыла фармаваньне. На чарзе - перамога беларускай мовы, https://svabod1.azureedge. net/a/30681590.html [dostęp: 31.05.2021].

29 „Przepraszam, będę mówił po rosyjsku, ale język białoruski jest piękny, ja go kocham..." [tłum. na potrzeby własne - R.K.].

30 „Zacznę w języku ojczystym, ale formułować myśli jest mi łatwiej po rosyjsku. Bardzo proszę mi to wybaczyć..." [tłum. na potrzeby własne - R.K.].

31 „Nasz język jest najpiękniejszy, ja niestety mało w nim mówię...” [tłum. na potrzeby własne - R.K.].

32 „Widzi pan, ja niezbyt pewnie mówię w języku ojczystym...” [tłum. na potrzeby własne - R.K.].

33 „Odrodzimy język ojczysty, on jest świetny...” [tłum. na potrzeby własne - R.K.]. 
Jest to więc nowy rodzaj wstydu - już nie z powodu używania białoruszczyzny, ale z powodu jej nieużywania. Ten rodzaj wstydu prowadzi do postawy honorowej - bycia dumnym ze swojego języka, co rodzi też motywację do jego nauczenia się, przypomnienia sobie, czy po prostu stosowania w życiu codziennym.

\section{Podział społeczny odzwierciedlany w języku}

\section{Dziennikarz Siarhiej Dubawiec (błrus. Сяргей Дубавец) stwierdza:}

Мова - наш галоўны ўнутраны дыскамфорт. І гэта праўда, якую вам пацьвердзіць кожны беларускамоўны, які штодня перажывае гэты дыскамфорт у краме, у транспарце, у паліклініцы... Там сёньня праходзіць лінія фронту ў гэтай вайне за перамены. I калі ў цырульні беларускамоўны дэмакрат сустракае свайго калегу з апазыцыйнай кааліцыі, які пасуе перад рускамоўнасьцю асяродзьдзя, яны, гэтыя двое, апынаюцца па розныя бакі гэтай лініі фронту. І колькі б пасьля яны не дэкляравалі адзінства дэмакратычных сілаў, гэтае адзінства немагчымае - на ўзроўні гіпофіза. Бо насамрэч адзін зь іх змагаецца за незалежнасьць краіны і наступныя за ёй дэмакратычныя эўрапейскія каштоўнасьці, а другі - за ўтульнасьць быць дэмакратам у расейскай правінцыі ${ }^{34}$.

Język w tej koncepcji jest linią podziału społeczeństwa - wyznacznikiem wyznawanych wartości i poglądów politycznych:

у беларускай дэмакратыі больш няма нічога сьвятога. Апроч мовы. Гэтую каштоўнасьць згубіць проста немагчыма. Яна застаецца галоўным крытэрам адрозьненьня апазыцыі і ўлады, дэмакратыі і сатрапства, незалежнасьці і правінцыйнасьці, культуры і сэрвіроўкі царскага стала ${ }^{35}$.

34 „Język to nasz główny dyskomfort wewnętrzny. I to prawda, którą wam potwierdzi każdy białoruskojęzyczny, który co dzień odczuwa ten dyskomfort w sklepie, w komunikacji miejskiej, w przychodni... Tam dziś przebiega linia frontu w wojnie o zmiany. I kiedy u fryzjera białoruskojęzyczny demokrata spotyka swego kolegę z koalicji opozycyjnej, który pasuje przed rosyjskością środowiska, to oni, ci dwaj, znajdują się po różnych stronach tej linii frontu. I ile by oni potem nie deklarowali jedności sił demokratycznych, to ta jedność nie jest możliwa - na poziomie przysadki mózgowej. Bo w rzeczy samej jeden z nich walczy o niepodległość kraju i wynikające z niej demokratyczne wartości europejskie, a drugi o przytulność bycia demokratą w rosyjskiej prowinicji” [tłum. na potrzeby własne - R.K.]. Zob. C. Дубавец, Мова gэмакратыі і мова gыктатуры, https://www.svaboda.org/a/ dubaviec-mova-demakratyi-i-mova-dyktatury/24737826.html [dostęp: 31.05.2021].

35 „Demokracja białoruska nie ma już więcej niczego świętego. Oprócz języka. Tej wartości nie wolno stracić. Ona pozostaje głównym kryterium odróżnienia opozycji i władzy, 
Społeczeństwo białoruskie jest bardzo podzielone pod różnymi względami: prawosławni i katolicy, Białorusini i nie-Białorusini, białoruskojęzyczni i rosyjskojęzyczni, białoruskojęzyczni używający miękkiego znaku ${ }^{36}$ i białoruskojęzyczni nieużywający miękkiego znaku, zwolennicy rewolucji (tzw. „nowej Białorusi”) i zwolennicy Łukaszenki itd. To podział stereotypowy i każda grupa ma jeszcze swoje odcienie, np. wśród osób rosyjskojęzycznych mogą być osoby: 1) pozytywnie nastawione do języka białoruskiego, choć się nim nieposługujące, 2) negatywnie nastawione i 3) neutralnie lub obojętnie nastawione ${ }^{37}$. Piotr Rudkouski (błrus. Пётр Рудкоўскі) dzieli grupy społeczne ze względu na przyjętą filozofię języka. Są osoby uznające język za wartość absolutną (sacrum) i takie, które uważają go za środek komunikacji. W obu grupach mogą być zarówno osoby białoruskojęzyczne, jak i rosyjskojęzyczne ${ }^{38}$. Z kolei białoruski dziennikarz wolnościowy Siarhiej Abłamiejka twierdzi, że negatywnie nastawieni do języka białoruskiego są albo Białorusini, którzy wyrzekli się swych korzeni i mogą mieć z tego powodu wyrzuty sumienia, albo osoby innego pochodzenia niż białoruskie, np. Rosjanie. Natomiast ci, którzy uznają świadomie swoją narodowość za białoruską, nie mają negatywnego nastawienia do białoruszczyzny ${ }^{39}$, nawet jeśli z różnych powodów się nią (jeszcze) nie posługują.

Dodatkowo zwolennicy idei narodowej (nie tylko politycy, lecz także publicyści czy naukowcy) uważają białoruszczyznę za fundament niepodległego państwa:

Беларускую мову неабходна абвясьціць адзінай дзяржаўнай мовай. Яе статус павінен быць прыярытэтны. Інакш мы нічым ня будзем адрозьнівацца ад суседзяў. Наш распазнавальны знак - мова, і мы павінны яе культываваць ${ }^{40}$.

demokracji i tyranii, niepodległości i prowincjalności, kultury i zastawy stołu carskiego" [tłum. na potrzeby własne - R.K.]. Zob. С. Дубавец, Мова gэмакратыi.

${ }^{36}$ Co pokazuje, że użytkownicy białoruszczyzny też różnią się między sobą. Oficjalny język białoruski także różni się od nieoficjalnego, np. ortografią, jak w przypadku Radia Svaboda, które stale na swej stronie posługuje się wariantem klasycznej ortografii zwanej popularnie „taraszkiewicą” od nazwiska jej twórcy Bronisława Taraszkiewicza (błrus. Браніслаў Тарашкевіч).

37 Por. А.А. Сомин, Языковая рефлексия в современной Беларуси сквозь призму комментариев в интернет-СМИ, „Вестник РГГУ” Серия „Филологические науки. Языкознание"/ Московский лингвистический журнал 2015, т. 17 (1), s. 70.

38 П. Рудкоўскі, Паўстаньне Беларусі, Вільня 2007, s. 121-122.

39 С. Абламейка, Маральная сіла беларушчыны і амаральнасьць яе непрыяцеляў, https://www.svaboda.org/a/24756421.html [dostęp: 31.05.2021].

40 „Język białoruski koniecznie trzeba ogłosić jedynym językiem państwowym. Jego status powinien być priorytetowy. Inaczej my niczym nie będziemy się różnić od sąsiadów. 
Inni zaś wskazują przykłady Irlandii, Austrii czy Szwajcarii, gdzie kwestia językowa nie stanowi o poczuciu odrębności narodowej.

Nawet eksperci są podzieleni i stosuje się etykietki do określania ich różnych poglądów, np. „reżimowi językoznawcy z Akademii Nauk” i „niereżimowi językoznawcy”, jak nieżyjący już Źmicier Sauka (błrus. Зьміцер Саўка) сzy Winczuk Wiaczorka (błrus. Вінцук Вячорка). Ten ostatni ma swój kanał na Telegramie o nazwie Język z Wolnościq - Radiem Wolność (błrus. Mова ca Свабоgай), w którym analizuje osobliwości białoruszczyzny na współczesnych przykładach z białoruskiej rzeczywistości. Pokazywane są np. słowa typowo białoruskie, których można używać zamiast rusycyzmów, m.in. заробак 'pensja' (por. pol. zarobek) zamiast зарплата 'pensja' (por. ros. зарплата, заработная плата).

Jest to tendencja zwana $w$ literaturze nacjonalizacją ${ }^{41}$, czyli pozbywaniem się leksemów podobnych do tych, które występują w języku rosyjskim na rzecz typowo białoruskich, które jednak często mają polskie korzenie ${ }^{42}$, czego nie wszyscy użytkownicy są świadomi. Oto jak występowanie w białoruszczyźnie zapożyczeń z języka polskiego komentuje białoruska badaczka:

Аднак, калі на пачатку XX ст паланізмы траплялі ў літаратурную мову не толькі кніжным шляхам, але і праз мясцовыя гаворкі, то з канца стагоддзя іх выкарыстанне падтрымлівалася маўленчай практыкай 1920-х гадоў і пэўнай пісьмовай традыцыяй. У той жа час не ўсе носьбіты беларускай мовы ўсведамлялі тады і ўсведамляюць сёння польскамоўны характар такіх сродкаў; многімі яны ўспрымаюцца як некалі

Nasz znak rozpoznawczy to język i powinniśmy go kultywować" [tłum. na potrzeby własne - R.K.]. Zob. Д. Гурневіч, Як без прымусу вярнуць беларускую мову. Разьбіраемся з gасьлеgніцай моўнае палітыкі, https://svaboda.azureedge.net/a/31255378.html [dostęp: 31.05.2021].

41 Por. А.А. Лукашанец Беларуская мова у XXI стагоggзі. Развіццё сістэмы і праблемы функцыянавання, Мінск 2014, s. 25; R. Kaleta, O niektórych tendencjach, S. 390.

42 Wiele polonizmów uważanych jest przez białoruskie źródła słownikowe za archaizmy, które kiedyś odgrywały ważną rolę - na wcześniejszych etapach rozwoju języka białoruskiego, który rozwijał się pod dużym wpływem polszczyzny, por. С.М. Струкава, Слоўнік архаізмаў і гістарызмаў (па творах беларускай мастацкай літаратуры і публіцыстыкі), Мінск 2007, s. 9; Р. Калета, Лексічны аналіз паланізмаў-архаізмаў у беларускай мове (на матэрыяле беларускага Слоўніка архаізмаў і гістарызмаў), [w:] Беларуска-польскія культурна-моўныя ўзаемаgачыненні: ag гісторыі gа сучаснасці: зб. навук. арт., рэд. В.М. Курцова, Н.А. Снігірова, М. Jankowiak, M. Ostrówka, Мінск 2016, s. 123-128. 
перыферыйныя, „забытыя”, але ўласнабеларускія словы і формы. У любым выпадку iх паходжанне адыходзіць на другі план, а на першы выступае адпаведнасць моўным пурыстычным патрабаванням. Такая нацыяналізацыя мовы асабліва яскрава праявілася падчас другой хвалі беларусізацыі пачатку 1990-х гадоў і працягваецца па сёння ${ }^{43}$.

Polonizmy w kontekście nacjonalizacji są motywowane czynnikami pozajęzykowymi i nieneutralnymi, a emocjonalnymi ${ }^{44}$.

Obecnie w dyskursie internetowym raczej dominuje wzajemne obrażanie się zwolenników różnych koncepcji. Osoby posługujące się białoruszczyzną uznawane są przez swoich zwolenników za elitę, a przez przeciwników - za getto, które nie chce zaakceptować rzeczywistości istnienia rosyjskojęzycznej kultury Białorusi. Osoby rosyjskojęzyczne są z kolei stereotypowo uznawane za osoby mało wykształcone, poddane propagandzie rosyjskiej, pogodzone z istnieniem Białorusi jako rosyjskiej prowincji i wygodnicko szukające w niej miejsca na swoją karierę.

Kto zatem używa języka białoruskiego? Według dziennikarza Radia Svaboda, Siarhieja Abłamiejki, świadomi Białorusini, którzy mają odwagę myśleć niezależnie od propagandy szkolnej i medialnej, według której Białorusini i Rosjanie to jeden naród lub Białorusin to Rosjanin ze znakiem jakości ${ }^{45}$. To osoby, które nie utożsamiają się już z dziedzictwem ZSRR, nie ulegają rosyjskiej kulturze masowej. To także inteligencja oraz Kościół katolicki (w przeciwieństwie do Cerkwi prawosławnej będącej częścią rosyjskiej struktury propagującej ideę świętej Rusi), który jest jedynym bastionem, gdzie na Białorusi nie używa się

43 „Jednak, jeśli na początku XX w. polonizmy trafiały do języka literackiego nie tylko drogą książkową, lecz także poprzez gwary miejscowe, to od końca stulecia ich wykorzystywanie wspierane było przez praktykę języka mówionego lat 20. XX w. i przez pewną tradycję piśmienniczą. W tym czasie nie wszyscy nosiciele języka białoruskiego byli wówczas świadomi i nie są świadomi też dziś polskojęzycznego charakteru takich środków; wiele osób uważa je za takie słowa i formy, które kiedyś były peryferyjne, „zapomniane”, ale typowo białoruskie. W każdym razie ich pochodzenie schodzi na drugi plan, a na pierwszy wysuwa się to, czy odpowiadają one purystycznym wymaganiom językowym. Taka nacjonalizacja języka szczególnie barwnie zamanifestowała się podczas drugiej fali białorutenizacji na początku lat 90. XX w. i trwa po dziś dzień" [tłum. na potrzeby własne - R.K.]. Zob. М. Свістунова, Вывучэнне паланізмаў у беларускім мовазнаўстве (40-я гаgы XX ст. - XXI ст.), „Studia Białorutenistyczne” 2017, nr 11, s. 254.

44 Ibidem.

45 Por. С. Абламейка, Маральная сіла беларушчыны. 
właściwie języka rosyjskiego ${ }^{46}$. Dyskusje te zaogniły się w wyniku bardzo brutalnej reakcji władz na panującą w kraju sytuację powyborczą ${ }^{47}$.

\section{Perspektywy}

Publicyści Radia Svaboda często przytaczają opinie mówiące, iż stopień rusyfikacji Białorusi jest tak duży, że nie da się już odrodzić języka białoruskiego, a raczej trzeba dalej tworzyć rosyjskojęzyczną kulturę Białorusi i w ten sposób ją zachować. Wydarzenia po 9 sierpnia 2020 r. pokazały, że to nieprawda w dość krótkim czasie Białorusini sami z siebie zaczęli świadomie używać białoruszczyzny w życiu codziennym. Gdyby więc na Białorusi zmieniła się polityka językowa, choćby w stronę realnego równouprawnienia dwujęzyczności państwowej, to sytuacja języka białoruskiego na pewno by się poprawiła. Jeszcze szybciej proces ten nastąpiłby, gdyby białoruszczyzna była jedynym językiem państwowym, ale nasuwa się pytanie, czy białoruskie społeczeństwo byłoby na to gotowe od razu. Raczej nie. Należałoby zatem wprowadzić jakiś etap przejściowy, aby dać obywatelom czas na naukę białoruskiego, wzmocnić prawa języka białoruskiego oraz wyeliminować dyskryminację językową w mediach i szkolnictwie. Wtedy można by zaobserwować całkiem ciekawe tendencje samodzielnych wyborów Białorusinów, których dziś oni nie mają. Rodzice nie mają bowiem wyboru, czy posłać dziecko do przedszkola białoruskojęzycznego, czy rosyjskojęzycznego. Gdyby go mieli, efekty mogłyby być bardzo ciekawe, bo jednak spora część Białorusinów bywała w różnych częściach Europy, obserwuje też przemiany na Ukrainie, więc z powodzeniem podobne procesy mogłyby się odbywać na Białorusi. Już nawet teraz białoruscy politycy rozumieją, że muszą umieć udzielić wywiadu po białorusku, że ma to moralne i symboliczne znaczenie. Dawno zrozumieli to już białoruscy dyplomaci za granicą.

Siarhiej Abłamiejka uważa, że język białoruski jako język narodowy będzie jedynym językiem urzędowym - podobnie, jak to jest w innych krajach europejskich, które mają jeden język państwowy, choć żyją w nich przedstawiciele różnych narodowości mający prawnie zagwarantowane używanie języków

46 Por. М. Гракаў, „Беларуская мова уу сферы sacrum”. Ці буgзе нарэшце пачуты голас Касцёла?, https://catholic.by/3/news/belarus/7619-belaruskaya-mova-sfery-sacrumtsi-budze-nareshtse-pachuty-golas-kastsjola [dostęp: 31.05.2021].

47 Por. dyskusje i komentarze, np.: А. Аблажэй, Атака троечнікаў, https://www.svaboda.org/a/24742362.html [dostęp: 31.05.2021] і С. Абламейка, Гета або эліта?, https:// www.svaboda.org/a/24742277.html [dostęp: 31.05.2021]. 
mniejszościowych, co jednak nie wpływa na ustanowienie wielojęzyczności oficjalnej ${ }^{48}$. Dziennikarz stwierdza, że choć w sferze prywatnej każdy może używać takiego języka, jakiego chce, to jednak językiem państwowym będzie białoruski. Według autora jest to moralny obowiązek nowego rządu wobec ofiar tortur i rozstrzelań, którzy oddali swe życie w Kuropatach i w obozach na Syberii ${ }^{49}$. Dotyczy to także walczących w czasie rewolucji godności 2020 roku. Abłamiejka uważa, że nie można tu wymagać demokratycznego współistnienia języka rosyjskiego i białoruskiego, bo to istnienie nie było wprowadzone demokratycznie, ale przymusowo:

Думаю, што беларусы уу адказ на гвалтоўную рысыфікацыю апошніх двух стагодзьдзяў змогуць адказаць не аналягічнай беларусыфікацыяй, але нармальнай, узважанай і доўгатэрміновай беларусізацыяй ${ }^{50}$.

Procesy wyzbywania się języka białoruskiego, wstydzenia się go (dyskryminacji), a następnie powrotu do niego (rehabilitacji) mają tendencję falową uzależnioną od wydarzeń społeczno-politycznych. Perspektywy białoruszczyzny zależą zatem od koniunktury politycznej w przyszłości, a nie od czynników czysto językowych. Scenariusz polityczny będzie miał wpływ na politykę językową. Przykład dany z góry będzie oddziaływał na zwykłych ludzi. Jeśli reżim Łukaszenki przetrwa, to białoruszczyzna będzie wciąż kojarzona z demokratyczną opozycją, z której propaganda robi ekstremistów i terrorystów, zatem używanie języka białoruskiego będzie właśnie za takie uchodziło - wciąż nie będzie w dobrym tonie i będzie symbolem próby destabilizacji sytuacji w kraju. Jest to proces o tyle niebezpieczny, o ile będzie pogłębiał nie tylko wstyd językowy, o którym wspomina Uładzisłau Iwanou (błrus. Уладзіслаў Іваноў), lecz także będzie przeradzał ten wstyd w (auto)nienawiść do języka białoruskiego ${ }^{51}$. Nastąpi jeszcze większy podział społeczeństwa oraz wzmocnienie i tak już istniejących postaw dyskryminacji językowej stosowanych przez resorty siłowe

48 С. Абламейка, Маральная сіла беларушчыны...

49 Ibidem.

50 „Myślę, że Białorusini w odpowiedzi na gwałtowną rusyfikację ostatnich dwóch wieków będą w stanie odpowiedzieć nie analogiczną białorutenizacją, ale normalną, wyważoną i długoterminową" [tłum. na potrzeby własne - R.K.]. Zob. С. Абламейка, Маральная сіла беларушчыны.

51 U. Iwanou podaje przykłady takiej nienawiści na podstawie wypowiedzi nie tylko białoruskiego dyktatora, lecz także białoruskiej wioślarki, która jasno wypowiedziała się, że białoruszczyzna jest niepotrzebna. Zob. У. Іваноў, Моўны сорам беларусаў, s. 170 . 
wobec zwykłych obywateli jako zemstę za ich przejawy postaw obywatelskich wynikających ze świadomości narodowej.

Dyskryminacja ta może się trochę zmniejszyć w sytuacji całkowitego stłumienia protestów i kontroli społeczeństwa. Jedynym miejscem w miarę bezpiecznym dla białoruszczyzny pozostanie Kościół katolicki ze swoim wewnętrznym językiem (mocno jednak opartym na polonizmach) oraz humanistyczne ośrodki edukacyjne i naukowe, które tradycyjnie wykorzystują ten język w swych publikacjach i konferencjach. Prezydent Alaksandr Łukaszenka (błrus. Аляксандр Лукашэнка) publicznie rehabilitował białoruszczyznę tylko w sytuacji wybuchu konfliktu rosyjsko-ukraińskiego po zajęciu Krymu w 2014 r., żeby tym samym podkreślać suwerenność Białorusi. Obecnie sam dąży do tzw. integracji z Rosją, akceptując kolejne mapy drogowe, podkreślając jedność obu narodów, które łączy właśnie język rosyjski. W takiej atmosferze trudno spodziewać się reżimowego wsparcia białoruszczyzny na wielką skalę. Dopuszczane będą pojedyncze inicjatywy, jak np. tworzenie standardów (na wzór europejski) dotyczących języka białoruskiego jako obcego, czym można pozornie dowodzić, że państwo przecież coś dla białoruszczyzny robi. Obcokrajowcy mówiący po białorusku nie stanowią zresztą dla reżimu zagrożenia takiego jak białoruskojęzyczni (czyli świadomi) Białorusini.

W sytuacji zmiany opcji politycznej na Białorusi znaczenie białoruszczyzny na poziomie państwowym na pewno stopniowo by wzrastało. Być może najpierw funkcjonowałby model przejściowy, według którego najpierw uznano by dwujęzyczność państwową faworyzującą białoruski a nie rosyjski, a potem nastąpiłoby całkowite przejście na język białoruski jako państwowy z nadaniem językowi rosyjskiemu statusu języka pomocniczego lub regionalnego (np. na wschodzie Białorusi).

Na razie jednak rewolucja białoruska dokonała się w sercach i umysłach obywateli, którzy na swój prywatny użytek wracają do języka białoruskiego. Jest to tendencja nowa, ciekawa, nieoczekiwana, wymagająca jednak poświęceń i odwagi, na które nie wiadomo, na jak długo starczy narodowi sił.

Na zakończenie można by powtórzyć słowa Andrzeja Romanowskiego opublikowane ponad 20 lat temu: „Przyszłość języka białoruskiego jest w każdym razie nie mniejszą zagadką niż przyszłość samego narodu"52. Mimo upływu lat nie tracą one na aktualności - od tego, jak potoczy się białoruska rewolucja godności, zależą kolejne lata funkcjonowania języka białoruskiego, zaś obecna władza dokonała swego wyboru na rzecz języka rosyjskiego.

52 A. Romanowski, Dylematy językowe Białorusinów w przeszłości i dziś, [w:] Język a tożsamość narodowa, red. M. Bobrownicka, Kraków 2000, s. 132. 


\section{Bibliografia}

Ablamejka S., Belaruskaâ mova vyhodzic' na pârèdnì plân supracivu [Абламейка C., Беларуская мова выхоgзіць на пярэgні плян супраціву], https://svaboda1.azureedge.net/a/31139605.html.

Ablamejka S., Geta abo èlita? [Абламейка С., Гета або эліта?], https://www.svaboda. org/a/24742277.html.

Ablamejka S., Maral'naâ sila belaruščyny ì amaral'nas'c' âe nepryâcelâŭ [Абламейка C., Маральная сіла беларушчыны і амаральнасьць яе непрыяцеляу], https://www. svaboda.org/a/24756421.html.

Ablamejka S., Nacyâ belarusaǔ zakončyla farmavan'ne. Na čarze - peramoga belaruskaj movy [Абламейка С., Нацыя беларусаў закончыла фармаваньне. На чарзе - перамога беларускай мовы], https://svaboda1.azureedge.net/a/30681590.html.

Ablamejka S., Nadyšoǔ čas pisac'slova „Belarus”z' vâlikaj litary [Абламейка C., Нagышоўчас пісаць слова „Беларус” зь вялікай літары], https://svaboda1.azureedge.net/a/30890971.html.

Ablamejka S., Prafèsar Genadz' Cyhun: Belaruskaâ mova isnue šmat stagodz'dzâŭ [Абламейка C., Прафэсар Генаgзь Цыхун: Беларуская мова існуе шмат стагоgзьgзяу], https://svaboda1.azureedge.net/a/28189620.html.

Ablažèj A., Ataka troečnikaǔ [Аблажэй А., Атака троечнікау], https://www.svaboda. org/a/24742362.html.

Anâmenne, z hronikì zniščènnâ belaruskaj movy, Vil'nâ 2000 [Аняменне, з хронікі знішчэння беларускай мовы, Вільня 2000], https://knihi.com/none/Aniamiennie_Z_kroniki_zniscennia_bielaruskaj_movy.html.

Buraczok M., Dudka białoruska, Kraków 1891.

Dubavec S., Mova dèmakratyì i mova dyktatury [Дубавец С., Мова gэмакратыі і мова gыктатуры], https://www.svaboda.org/a/dubaviec-mova-demakratyi-i-movadyktatury/24737826.html.

Grakaǔ M., „Belaruskaâ mova ǔ sfery sacrum”. Ci budze narèšce pačuty golas Kascëla? [Гракаў М., „Беларуская мова у сферы sacrum”. ці буgзе нарэшце пачуты голас Касцёла?], https://catholic.by/3/news/belarus/7619-belaruskaya-mova-sfery-sacrumtsi-budze-nareshtse-pachuty-golas-kastsjola.

Gurnevič D., Âk bez prymusu vârnuc' belaruskuû movu. Raz'biraemsâ z das'lednicaj moǔnae palitykì [Гурневіч Д., Як без прымусу вярнуць беларускую мову. Разьбіраемся з gасьлеgніцай моўнае палітыкі], https://svaboda1.azureedge.net/a/31255378.html.

Gusakov V.G., Kovalenâ A.A., Belorussko-russkoe dvuâzyčie - istoričeski složivšaâsâ duhovno-kul'turnaâ cennost' naroda, „Doklady Nacional'noj akademii nauk Belarusi” 2020, t. 64, № 4, s. 506-512 [Гусаков В.Г., Коваленя А.А., Белорусско-русское gвуязычие - исторически сложившаяся gуховно-культурная ценность нароga, „Доклады Национальной академии наук Беларуси" 2020, т. 64, № 4, s. 506-512], https:// doklady.belnauka.by/jour/article/view/908/905\#. 
İvanoǔ U., Moǔny soram belarusaǔ (sacyâlingvistyčny analiz) [Іваноў У., Моўны сорам беларусаў (сацыялінгвістычны аналіз)], „Acta Albaruthenica” 2020, t. 20, s. 169-183. Kaleta R., Belorusskij âzyk kak (ino)strannyj, čužoj i rodnoj v načale XXI veka, [w:] Belaruskaâ mova ǔ XXI stagoddzì: asnoǔnyâ tèndèncyì razvìccâ (da 80-goddzâ akadèmika A.ì. Padlužnaga). Zbornìk matèryâlaǔ Mižnarodnaj navukovaj kanferèncyì, Mìnsk, 28-29 kastryčnika 2015 goda, red. L.A. Lìhadzìeǔskaâ i in., Mìnsk 2015, s. 142-149 [Калета Р., Белорусский язык как (ино)странный, чужой и роgной в начале XXI века, [w:] Беларуская мова ў XXI стагоggзі: асноўныя тэнgэнцыі развіцця (ga 80-гоggзя акаgэміка А.І. Паgлужнага). Зборнік матэрыялаў Міжнароgнай навуковай канферэнцыі, Мінск, 28-29 кастрычніка 2015 гoga, red. Л.А. Ліхадзіеўская i in., Мінск 2015, s. 142-149].

Kaleta R., Błędologia w glottodydaktyce białorutenistycznej, Warszawa 2018.

Kaleta R., Leksičny analìz palanìzmaǔ-arhaìzmaǔ u belaruskaj move (na matèryâle belaruskaga Sloǔnìka arhaìmaǔ ì gisstaryzmaǔ), [w:] Belaruska-pol'skiâ kul'turna-moǔnyâ ǔzaemadačynennì: ad gìstoryì da sučasnasci. Zb. navuk. art., rèd. V.M. Kurcova, N.A. Snìgìrova, M. Jankowiak, M. Ostrówka, Mìnsk 2016, s. 123-128 [Калета Р., Лексічны аналіз паланізмаў-архаізмаў у беларускай мове (на матэрыяле беларускага Слоўніка архаізмаў і гістарызмаў), [w:] Беларуска-польскія культурна-моўныя ўзаемаgачыненні: ag гісторыі gа сучаснасці. Зб. навук. арт., рэд. В.М. Курцова, H.А. Снігірова, М. Jankowiak, М. Ostrówka, Мінск 2016, s. 123-128].

Kaleta R., O niektórych tendencjach w funkcjonowaniu współczesnej białoruszczyzny, [w:] Białoruś w dyskursie naukowym. Lingwistyka, socjologia, politologia = Беларусь у навуковым gыскурсе. Лінгвістыка, сацыялогія, паліталогія [Belarus' u navukovym dyskurse. Lìngvistyka, sacyâlogiâ, palitalogîa] = Belarus in Scientific Discourse. Linguistics, Sociology, Political Science, red. R. Kaleta, Warszawa 2017, s. 389-408.

Kaleta R., Polsko-białoruska lapsologia glottodydaktyczna, Warszawa 2015.

Lukašanec A.A., Belaruskaâ mova ǔ XXI stagoddzì. Razvìccë sistèmy ì prablemy funkcyânavannâ, Mìnsk 2014 [Лукашанец А.А., Беларуская мова ў XXI стагоggзі. Развіццё сістэмы і праблемы функцыянавання, Мінск 2014].

Na knigu „Mova 404” pra dyskrymìnacyû za belaruskuû movu sabralì neabhodnuû sumu [На кнігу „Мова 404” пра gыскрымінацыю за беларускую мову сабралі неабхоgную суму], https://svaboda1.azureedge.net/a/31151140.html.

Olszański T.A., Problem językowy na Ukrainie. Próba nowego spojrzenia, „Prace OSW” 2012, nr 40, https://www.osw.waw.pl/sites/default/files/prace_40_0.pdf.

Pìrs A., Â vyhožu [Пірс А., Я выхожу], https://svaboda1.azureedge.net/a/31195495.html.

Romanowski A., Dylematy językowe Białorusinów w przeszłości i dziś, [w:] Język a tożsamość narodowa, red. M. Bobrownicka, Kraków 2000, s. 123-133.

Rudkoǔskì P., Paǔstan'ne Belarusi, Vìl'nâ 2007 [Рудкоўскі П., 2007, Паўстаньне Беларусі, Вільня 2007].

Somin A.A., Âzykovaâ refleksiâ v sovremennoj Belarusi skvoz' prizmu kommentariev v internet-SMI, „Vestnik RGGU” Seriâ „Filologičeskie nauki. Âzykoznanie” / „Moskovskij lingvističeskij žurnal", т. 17 (1), с. 62-86 [Сомин А.А., Языковая рефлексия в современной 
Беларуси сквозь призму комментариев в интернет-СМИ, „Вестник РГГУ” Серия „Филологические науки. Языкознание” / „Московский лингвистический журнал” 2015, t. 17 (1), s. 62-86].

Strukava S.M., Sloǔnik arhaìmaǔ ì gìstaryzmaǔ (pa tvorah belaruskaj mastackaj litaratury ì publicystyki), Mìnsk 2007 [Струкава С.M., Слоўнік архаізмаў і гістарызмаў (па творах беларускай мастацкай літаратуры і публіцыстыкі), Мінск 2007].

Svìstunova M., Vyvučènne palanìzmaǔ u belaruskim movaznaǔstve (40-â gady XX st. XXI st.) [Свістунова М., Вывучэнне паланізмаў у беларускім мовазнаўстве (40-я гаgы XX ст. - XXI ст.)], „Studia Białorutenistyczne” 2017, nr 11, s. 243-257.

Ulady adkazali: čytan'ne belaruskih pis'men'nikaǔ ne zabaronena, ale moža parušyc' zakon [Улаgы аgказалі: чытаньне беларускіх пісьменьнікаў не забаронена, але можа парушыць закон], https://svaboda.azureedge.net/a/31162195.html.

Vâčorka V., Našto kiraǔnictva Akadèmiì navuk Belarusì prynižae belaruskuû movu? [Вячорка B., Нашто кіраўніцтва Акаgэміі навук Беларусі прыніжае беларускую мову?], https:// svaboda1.azureedge.net/a/svintus-grandiosus-immortalis-et-aeternus/30890969.html. 


\title{
Мы выйшлі на вуліцу знянацку так... Muzyka jako narzędzie budowania białoruskiej tożsamości oporu
}

\author{
"We stepped outside so suddenly..." Music as a tool for building Belarusian \\ resistance identity
}

Mass protests after the August 2020 presidential elections in Belarus laid bare all the weaknesses of the official propaganda machine and exposed not only the deficit of truth in relations between the authorities and society: they disavowed and ridiculed both the organizational efforts undertaken by the government and the narrative threads that set the long-term strategy of official propaganda and in doing so, destroyed its foundations. The music of the protests played a significant role in this process. The article analyzes the texts as well as the visual aspect of the music videos, which, from a social perspective, contributed to the change of the political situation in Belarus. Alaksandr Lukashenka's policy and himself as a guarantor of social peace and stability are discredited, and the image of a society rebellious against the pretence of values, perpetuated by the system of power built by Lukashenka, is the major theme. The music of the protests shapes the community and modern cultural identity of Belarusians around separate Belarusian cultural codes concerning language, traditions, history and heroes. Songs of resistance, most often written in response to current events, in their verbal layer carry authentic messages, alternative to the official "ideology of truth". In this way, musical works become a tool for social controversy and fight against the system, i.e. an important part of the process of change and building a new national identity. Ke y w ord s: Belarus 2020 protests, Alaksandr Lukashenka, music, resistance society

Мы выйшлі на вуліцу знянацку так... Muzyka jako narzędzie budowania białoruskiej tożsamości oporu

Masowe protesty po sierpniowych wyborach prezydenckich w Białorusi unaoczniły wszystkie słabości oficjalnej machiny propagandowej i obnażyły nie tylko deficyt prawdy w relacjach władza - społeczeństwo: zdezawuowały i ośmieszyły również podejmowane przez ośrodek prezydencki wysiłki

1 błrus. Wyszliśmy na ulicę znienacka tak... NIZKIZ, Правілы, https://youtu.be/ SaTOst5utL8. 
organizacyjne, a także wątki narracyjne wyznaczające długoterminową strategię propagandy oficjalnej, niszcząc jej podstawy. Znaczną rolę w tym procesie odegrała muzyka protestów. W artykule analizowane są teksty, a także warstwa wizualna teledysków, które przyczyniły się do zmiany optyki społecznej dotyczącej sytuacji politycznej w Białorusi. Doszło do dyskredytacji zarówno polityki Łukaszenki, jak i jego samego jako gwaranta stabilności i pokoju społecznego. Na pierwszym miejscu widoczny jest obraz społeczeństwa zbuntowanego przeciwko pozorom wartości, utrwalanym poprzez zbudowany przez Łukaszenkę system władzy. Muzyka protestów kształtuje wspólnotę i nowoczesną tożsamość kulturową Białorusinów wokół odrębnych białoruskich kodów kulturowych dotyczących języka, tradycji, historii i bohaterów. Pieśni oporu, powstałe najczęściej w reakcji na bieżące wydarzenia, w swej warstwie słownej niosą treści autentyczne, alternatywne do oficjalnej „ideologii prawdy”. W ten sposób utwory muzyczne stają się narzędziem kontestacji społecznej, walki z systemem, tj. istotną kulturową częścią procesu zmian, budujących nową tożsamość narodową. Słow a kluczowe: protesty Białoruś 2020, Łukaszenka, muzyka, społeczeństwo oporu

\section{Wprowadzenie}

Masowe protesty po sierpniowych wyborach prezydenckich w Białorusi unaoczniły wszystkie słabości oficjalnej machiny propagandowej i obnażyły nie tylko deficyt prawdy w relacjach władza - społeczeństwo: zdezawuowały i ośmieszyły także podejmowane przez ośrodek prezydencki wysiłki organizacyjne, a także wątki narracyjne wyznaczające długoterminową strategię propagandy oficjalnej, niszcząc jej podstawy. Niezależnie od politycznego rozstrzygnięcia trwający wciąż, zapoczątkowany w 2020 r., kryzys będzie miał trwałe konsekwencje polityczne, społeczne i kulturowe. Podważył bowiem samą istotę propagandy oficjalnej, której dominującym motywem był „Baćka Łukaszenka” jako gwarant stabilności i pokoju społecznego w Białorusi. Obraz ten został zepchnięty na dalszy plan przez obraz społeczeństwa zbuntowanego przeciwko pozorom wartości, utrwalanym przez zbudowany przez Alaksandra Łukaszenkę system władzy².

Kreowany przez 26 lat obraz stabilności Białorusi, panującego tam pokoju społecznego i odnoszonych na tym polu sukcesów prezydenta, legł w gruzach. Przyczyniły się do tego nowe media i technologie komunikacyjne (internet i smartfony). Zmieniły one także w sposób zasadniczy środki komunikacji społecznej: protest wytworzył specyficzny typ propagandy zarówno wizualnej (w przestrzeni realnej: transparenty, grafitti, wlepki, plakaty, w przestrzeni wirtualnej zaś: memy, filmiki, dowcipy sieciowe), jak i dźwiękowej (utwory muzyczne)

2 Szerszą analizę poruszonego w artykule problemu zawiera monografia: J. Getka, J. Darczewska, Na drodze do wolności. Białoruska partyzantka kulturowa w przestrzeni publicznej i w Internecie, Warszawa 2021. 
oraz audiowizualnej (wideoklipy). Stanowią one rodzaj dialogu z narracją oficjalną i bezpośredniego kontaktu z odbiorcą. Muzyka i wideoklip, wykorzystujące bodźce wizualne i tekst oraz fonię, stanowią odpowiedź „ulicy” na manipulację i dezinformację upowszechniane przez polityków i media państwowe.

Warto podkreślić, że muzyka jako przedmiot badań naukowych bywa rozpatrywana na różnych płaszczyznach - jako forma: komunikacji międzyludzkiej, kulturowej ekspresji symbolicznej, kontestacji społecznej i negacji kultury dominującej, a także budowania tożsamości narodowej i więzi społecznych między jej odbiorcami. Jako forma komunikacji międzyludzkiej jest medium uniwersalnym, a przy tym masowym: muzyk przedstawia komunikat, a odbiorcy koncentrują uwagę na jego przekazie. Komunikacja ta ma specyficzne cechy: niesie ze sobą określone kody kulturowe, dzięki którym muzyka staje się nośnikiem określonych znaczeń ${ }^{3}$. Tekst wzmocniony przez rytm i udźwiękowienie oddziałuje szybciej niż poezja czytana. Jest to także przyczyna większej popularności poezji niż form prozatorskich, które wyraźnie nie nadążają za dynamiką kryzysów i przesileń w relacjach społecznych i politycznych.

Społeczeństwo, zmuszone do konfrontacji swych ocen z rzeczywistością, uwalnia ogromne pokłady innowacyjności - w tym przypadku ustami muzyków. Zastosowanie całego arsenału znaków i symboli w walce o racjonalną społeczną refleksję nad białoruską rzeczywistością oraz upodmiotowienie społeczeństwa (którego przejawem są wolne wybory) jest efektem głębokiej krytyki rzeczywistości wykreowanej - „systemu Białoruś”.

Analiza systemowa (uwypuklająca takie wyróżniki systemu władzy Łukaszenki, jak opresyjność, propaganda czy cenzura) pozwala wyjaśnić trwałość reżimu i determinację jego obrony, nawet kosztem suwerenności. Jest jednak mało przydatna do opisu zmarginalizowanego przez system społeczeństwa i anatomii jego protestu. Obserwowane dziś tendencje łamią stosowane do jego opisu paradygmaty. Od wyborów prezydenckich w 2006 r. za główny czynnik zmian społecznych w Białorusi uznano konflikt pokoleń (różnice celów i strategii). W 2020 r. zmieniły się zarówno motywacje oporu wobec reżimu, jak i geografia protestu. W efekcie runął stereotypowy wręcz wizerunek socjologiczny oponenta Łukaszenki: jako człowieka młodego, wykształconego, zorientowanego na Zachód mieszkańca Mińska. Dziś w protestach uczestniczą zarówno studenci, jak i emeryci, a także robotnicy z Mińska, Grodna, Brześcia, Witebska, Soligorska i innych miast. Z tego względu kontekst

3 B. Jabłońska, O społecznym charakterze muzyki. Szkic socjologiczny, „Pogranicze. Studia Społeczne" 2018, t. 34, s. 114.

${ }^{4}$ Metafora za: A. Poczobut, System Białoruś, Warszawa 2013. 
teoretyczny niniejszych rozważań musi zostać poszerzony o koncepcję społeczeństwa oporu Castellsa ${ }^{5}$.

Analiza powstałych w 2020 r. (w językach białoruskim i rosyjskim) utworów białoruskich twórców, będących narzędziem kontrpropagandy społecznej, „rozbrajającej” arsenał środków propagandy oficjalnej, ma na celu ustalenie, czy i w jaki sposób muzyka staje się motorem zmiany społecznej i kulturowej (narzędziem budowania białoruskiej tożsamości oporu). Inaczej mówiąc: na ile świadomość i postawy społeczeństwa biernego, monologicznego, przekształca w światopogląd aktywnego społeczeństwa dialogu. Protestujący - jako uczestnicy swoistej debaty publicznej - odrzucają forsowaną odgórnie tożsamość zbiorową i przydzieloną społeczeństwu rolę legitymizacyjną państwowych instytucji władzy (zwłaszcza dominacji władzy prezydenta), na rzecz tożsamości oporu przeciwko pozornym wartościom i systemowej opresji. Mechanizm konstruowania tego typu tożsamości polega na wykluczeniu wykluczających przez wykluczanych, odwróceniu ocen, odwróceniu kategorii operatywnego dyskursu, budowaniu poczucia wspólnotowości i szańców obronnych do obrony wspólnych wartości ${ }^{6}$. Dominującą postulowaną wartością jest podmiotowość społeczeństwa, którą symbolizuje niezmiennie towarzyszące protestom hasło wolnych wyborów.

Pieśni oporu, powstałe najczęściej w reakcji na bieżące wydarzenia, w swej warstwie słownej niosą ponadto treści autentyczne, alternatywne do oficjalnej „ideologii prawdy”. W ten sposób utwory muzyczne stają się narzędziem kontestacji społecznej, walki z systemem, tj. istotną kulturową częścią procesu zmian, budujących nową tożsamość narodową.

W tym kontekście należy zauważyć, że siłę i wiarygodność białoruskiego przekazu muzycznego potęgują dodatkowo takie jego charakterystyki, jak spontaniczność, oddolny charakter, spójność działań artystycznych, funkcjonowanie we własnym podziemnym obiegu, a także aktualna tematyka, trafiająca w oczekiwania Białorusinów. Determinuje to także jego wyjątkową funkcję w wymiarze kulturowym: przekaz ten zastępuje lekcje historii i języka ojczystego, przypomina kolejnym pokoleniom, że o kraj, jego wolność należy walczyć. W ten sposób kształtuje i utrwala tożsamość narodową. Te same narodowe kody kulturowe są przenoszone z tekstów utworów na transparenty, są powielane i wzmacniane z głośników podczas protestów. Nowe trendy informacyjno-komunikacyjne ponadto wydatnie poszerzyły zasięg ich oddziaływania, co w wymierny sposób pokazuje liczba wyświetleń poszczególnych utworów na portalu YouTube.

\footnotetext{
${ }^{5}$ M. Castells, Społeczeństwo sieci, tłum. M. Marody i in., Warszawa 2007.

${ }^{6}$ M. Castells, Siła tożsamości, tłum. S. Szymański, Warszawa 2008, s. 24-28.
} 


\section{Muzyka oporu jako nośnik wartości kulturowych}

Kulturowy i antysystemowy wymiar pieśni oporu podkreślają białoruscy artyści. W ich opinii muzyka jest jak broń. To dzięki tym utworom protest Białorusinów ma charakter nie tylko polityczny, lecz także estetyczny ${ }^{7}$. Współczesna kultura białoruska, w tym muzyczna, jest kontrolowana przez władze i podporządkowana ich polityce kulturalnej, ideologicznej, edukacyjnej, historycznej i in. W odgórnym przekazie państwowym odbiorca białoruski otrzymuje najczęściej pieśni estradowe twórców wspierających system, folklorystycznych zespołów ludowych oraz pieśni patriotyczne z lat wojny. Utrzymane w konwencji oficjalnego patosu mają one dwojaką funkcję: służąc rozrywce, realizują stosowne cele ideologiczne.

Białoruskie pieśni oporu - na odwrót - sprowadzają ideologię (patriotyzm) na poziom kultury popularnej, a kulturowe procesy tożsamościowe odklejaja od obowiq̨zującego w przeszłości patosu i oficjalności $i^{8}$. Pod względem gatunku są one bardzo urozmaicone: w czasie protestów można było usłyszeć zarówno śpiew operowy, pieśń hymniczną i bardowską, jak i różne style muzyki rozrywkowej - reggae, rock, punk, punk-rock, rock alternatywny, metal, death metal, hardcore, folk, muzykę elektroniczną, rap, hip-hop, pop itd. Wskrzeszając „ducha narodu", muzycy łączą różne gatunki, nie gardząc wspomnianymi pieśniami ludowymi, które - po wejściu w nurt pieśni zaangażowanej - stają się antysystemowymi manifestami (znakomitym tego przykładem może być np. przejmujące wykonanie Kupalinki przez trzymające się za ręce kobiety otoczone OMONowcami pod Czerwonym Kościołem 1 września 2020 r. w Mińsku).

Niebezpieczne związki muzyki z polityką i ideologią dostrzegają władze, traktując je nie bez racji jako poważne wyzwanie. Pieśni niezgody z oficjalną polityką, zorientowane na zmianę, na bieżąco interpretują wydarzenia polityczne w kraju, odzwierciedlają i dokumentują najważniejsze etapy i momenty zwrotne protestów. Teksty piosenek są przenoszone na transparenty: są czytelnymi hasłami, pod którymi idą protestujący. Jednym z najbardziej rozpoznawalnych jest hasło: Перемен! (ros. [Chcemy] zmian!), zaczerpnięte z tyłułu utworu radzieckiej grupy KINO, uznanego za nieformalny hymn opozycji radzieckiej.

7 Por. wypowiedź didżeja Alaksandra Bahdanoŭa i Kiryla Hałanoŭa dla portalu Настоящее Время: Ольга Бешлей, Музыка протестов. Какие песни звучат на улицах Беларуси, 9.09.2020, https://www.currenttime.tv/a/30829355.html [dostęp: 18.06.2021].

${ }^{8} \mathrm{~W}$ odniesieniu do polskiej muzyki pop temat ten szczegółowo omówił prof. Pęczak z UW. Zob. M. Pęczak, Subkultury w PRL. Opór, kreacja, imitacja, Warszawa 2013; idem, „Patriotyzmy” polskiej muzyki popularnej, „Kultura Współczesna” 2014, nr 1 (84). 
Wokalista zespołu i autor jego tekstów Wiktor Coj symbolizował sprzeciw wobec polityki Kremla i totalitarnego systemu. Został oceniony jako niebezpieczny przez administrację białoruską, która „Didżejów zmian”, Cyryla Hałanoǔa i Uładzisława Sakałoǔskiego, za jej wykonanie 6 sierpnia 2020 r. skazała na 10 dni aresztu9 ${ }^{9}$. Jak stwierdził Sakałoǔski, wykonanie tego powszechnie rozpoznawalnego utworu podczas wiecu poparcia dla Cichanoǔskiej, spowodowało, że na nowo stał się on pieśnią buntu i „pieśnią zakazaną"10.

W tym kontekście należy odnotować, że w dobie wszechobecności internetu radiowe i telewizyjne stacje muzyczne schodzą na dalszy plan, a najbardziej adekwatną formą przekazu muzycznego staje się wideoklip umieszczany na kanale Youtube. Stanowi on krótki film muzyczny, w którym wykonywana piosenka ma oprawę wizualną ${ }^{11}$ a poprzez syntezę słowa, muzyki, obrazu ${ }^{12}$ wzmacnia funkcję komunikacyjną tego przekazu.

Choć wideoklip zwykle ma na celu odwzorowanie fabuły utworu ${ }^{13}$, to poprzez rozszerzenie oddziaływania na zmysł wzroku wzmacnia wpływ warstwy tekstowej i muzycznej utworu, a jednocześnie niesionych przez nie kodów kulturowych budujących interakcję społeczną. Potwierdza to analiza teledysków nagranych do utworów powstałych zarówno przed rokiem $2020^{14}$, jak i w czasie protestów. Modelowym tego przykładem jest pieśń grupy Nikziz Правілы (błrus. Zasady). O ile nagrana w czerwcu 2020 r. wersja audio mogła być interpretowana jako wyabstrahowany od sytuacji sygnał potrzeby działania, to nagrany we wrześniu wideoklip do tego utworu, zawierający sceny z pokojowych protestów przeciw fałszerstwom wyborczym, wnosi jednoznacznie polityczną interpretację. Wideoklip, w którym można zobaczyć przedstawicieli białoruskiej sceny muzycznej (takich jak Naviband, Louna), sceny ukraińskiej (Serhij Tanczynec z grupy БEZ ОБМЕЖЕНЬ) i rosyjskiej (Władimir Kotlarow z grupy Порнофильмы), śpiewaczkę operową Marharytę Liaǔczuk, ludzi

${ }^{9}$ Obaj muzycy zostali następnie zmuszeni do wyjazdu na Litwę.

10 W internecie (ByNecie) pojawiło się mnóstwo coverów tego utworu w wersji rosyjskojęzycznej, często w zaskakujących aranżacjach, np. heavymetalowa wersja Dymna Lotva, Перемен!, https://youtu.be/7QSTip3lpks.

11 Słownik współczesnego języka polskiego, red. B. Dunaj, Warszawa 1996, s. 512.

12 U. Jarecka, Świat wideoklipu, Warszawa 1999, s. 122.

13 K. Duszyk, Wideoklip jako komunikat medialny. Wartość estetyczna i funkcja, [w:] Komunikacja wizualna w prasie i w mediach elektronicznych, red. K. Wolny-Zmorzyński, W. Furman, J. Snopek, K. Groń, Warszawa 2013, s. 181.

14 Por. Анжаліка Агурбаш, Наўзgагон (2020), https://youtu.be/T9UXbViuAxU; Band A, Рэвалюцыя, https://youtu.be/6T-3qCiByKk. 
kultury, np. Julię Szewczuk z Wolnego Teatru i aktorów Teatru im. Janki Kupały, a także będącą ikoną białoruskich protestów Ninę Bahińską, wolontariuszy spod aresztu przy ul. Akreścina, przedstawicieli białoruskiej diaspory w Wielkiej Brytanii i Ameryce oraz setki pięknych wolnych Białorusinów, dopełniają skandowane podczas protestów hasło Żywie Biełaruś (błrus. Niech żyje Białoruś) ${ }^{15}$, co nadaje utworowi wymiar polityczny, narodowy i patriotyczny.

Wydarzenia pokazywane w białoruskich wideoklipach to najczęściej zdjęcia z protestów, wstrząsające kadry pokazujące brutalność sił porządku i rzeczywistą skalę protestu, przez co stają się swoistą ich dokumentacją z muzycznym komentarzem. Powszechnie stosowanym zabiegiem jest sięganie do kadrów z relacji z miejsc zdarzeń. Relacje te są emitowane przez portale Onliner.by, Tut.by, Nexta, Belsat, Radio Svaboda, DW, Euroradio.fm, Current Time, a także Sputnik, Ont.by, Беларусь 1, tacc.ru. Wykorzystywane są także prywatne zdjęcia i nagrania z różnych miast Białorusi ${ }^{16}$.

Taka wizualizacja warstw muzycznej i tekstowej utworów pokazuje zarazem emocje, bunt i niezgodę środowiska muzycznego na ograniczanie praw i wolności człowieka, stając się nośnikiem ich funkcji ideologicznej. Odbiorca może się identyfikować ze sportretowanymi na teledysku postaciami czy wydarzeniami ${ }^{17}$. Wideoklipy zawierają mnóstwo zideologizowanych symbolicznych obrazów: narodu, który buduje solidarną wspólnotę, społeczeństwa pokojowo nastawionego do świata, dumnego ze swego kraju i języka, a także swej niezłomnej walki, która przykuwa oczy całego świata.

Warto przy tym zwrócić uwagę na proces tworzenia wideoklipów, który już sam w sobie jest swoistym projektem społecznym, często z udziałem ochotników. Wedle słów Źmiciera Haławacza, autora tekstów do pieśni zespołu TOR BAND Кто, если не ты?! (ros. Kto, jeśli nie ty?!) ${ }^{18}$, do nagrań klipu zgłosiły się 23 rodziny, niektóre z małymi dziećmi, niektóre przybyły z miejscowości odległych o ponad $400 \mathrm{~km}$, co świadczy o sile i jednoczącym wpływie wspólnoty idei ${ }^{19}$.

15 NIZKIZ, Правілы.

16 Sumarok, Чэрці, https://youtu.be/c6fgUy_8pbg.

17 M. Jeziński, Muzyka popularna jako wehikut ideologiczny, Toruń 2011, s. 223.

18 TOR BAND, Кто, если не ты?!, https://youtu.be/kQvKA2FAtwc.

19 «Кто, если не ты?» Tor Вand презентовал новую песню, https://nn.by/?c=ar\&i= 255097\&lang=ru. 


\section{Nie jesteśmy bydłem, stadem, tchórzami - jesteśmy żywym narodem - Białorusinami20}

Obok utworów znanych, które otrzymały nowe życie ${ }^{21}$, powstało mnóstwo nowych, oryginalnych pieśni. Dedykowane aktualnemu protestowi, były tworzone zarówno przez znane, legendarne już ugrupowania białoruskiej sceny muzycznej, jak i przez zespoły i twórców niszowych, którzy dawno temu zawiesili działalność artystyczną, a także muzyków, którzy zadebiutowali w 2020 r. Można tu wymienić m.in. utwory grup i artystów: Andrus Takindang, AP\$ENT, Botanic Project, Dzieciuki, Groove Dealer, Gonzo, Haina, lowa, J:MOPC, Maria Ermakova, Naviband, Nemiha, Nizkiz, Partyzanski Praspekt, Place To Be, Pylai, Rogal, Louna, Rooby Rich, Sciana, Sož, Sumarok, Таня Булавкина, TOR BAND, Val, Александр Баль, Александр Сериков, Алиса Титова Ft. Vic Villian Rostany, Виталий Артист, Дай Дарогу!, Долбушина И Пугач, Незабудки, Пирятин, Проект 4.0.4, Рита Дакота, Саша Захарик, Ян Кмит feat. Настя Зеленская. Lista ta, daleka od kompletności, świadczy nie tylko o potrzebie artystycznej ekspresji w reakcji na bieżące wydarzenia, ale i zaangażowaniu w sprawy kraju. Jak stwierdził Ilja Czarapko z grupy Петля пристрастия, był to dla muzyków czas próby: konsolidacja społeczeństwa była potrzebna jak nigdy dotąd $^{22}$. Tę lawinę zaangażowanych utworów uwarunkowało wiele czynników, m.in. chęć wyrażenia solidarności dla kolegów po fachu ${ }^{23}$, represjonowanych w 2020 r. za obywatelską postawę $e^{24}$, reakcja spowodowana osobistym doświadczeniem pobytu $w$ areszcie ${ }^{25}$, chęć pokazania, że ludzie kultury mówią jednym

20 TOR BAND, Мы - не „нароgец”!, https://youtu.be/Rai9tQCrRsQ.

${ }^{21}$ Np. N.R.M., Try čarapachi 2020, https://youtu.be/DIXB6YsMASE; Volski, Lohkija-lohkija, https://youtu.be/jy0_A46oz5U; Маргарыта Ляўчук, Лявон Вольскі, Паветраны шар, https://youtu.be/WoUh3872Dp8; Анжаліка Агурбаш, Наўзgагон (2020), https:// youtu.be/T9UXbViuAxU.

22 Naka feat. DZIECIUKI \& „Разбітае сэрца пацана” \& „Петля пристрастия” \& Rostany, ВАM (стихи Вл. Некляева), https://youtu.be/3IsHtovp1HA.

${ }^{23}$ Dziennikarka Katia Poliakowa z wykonanie utworu Przejrzyj straciła pracę w Telewizji Białoruskiej. Каця Пытлева, Ілля Маліноўскі, Угляgзіся, https://youtu.be/-Y4-J6u1GpY. Do aresztu trafiło wielu muzyków: Andrus Takindang, członek zespół Recha, stworzył nawet swoisty przewodnik, jak przetrwać areszt i jak się do niego przygotować.

${ }^{24}$ Sož, Malako, https://youtu.be/hn2bzjMRJ9U.

25 Jak utwór Laudans, Vysnova, https://youtu.be/6Omo0HTXGi0, napisany podczas pobytu w areszcie w Żodino. 
głosem ${ }^{26}$ w czasie próby, która zostanie zapisana w annałach historii Białorusi ${ }^{27}$. Budując solidarność społeczną, środowiska muzyczne zgodnie forsowały ideę, że tylko protestujący mogą w perspektywie stworzyć nową Białoruś, gdyż ludzie niewolni nie są w stanie wprowadzić zmian ${ }^{28}$.

Prowadzone przez muzyków działania, de facto oświatowe - tj. odsłaniające realne charaterystyki systemu, mają zadanie uświadamiające, odkłamujące rzeczywistość oficjalnych mediów, a tym samym konsolidujące społeczność oporu.

Szczególną aktywnością twórczą wykazała się grupa TOR BAND z Rohaczewa w obwodzie homelskim, która bywa porównywana do radzieckiego, później rosyjskiego zespołu ДДТ [DDT]. Utwory grupy wygrywały w nieoficjalnych konkursach na najlepszą pieśń protestów ${ }^{29}$. W czerwcu i lipcu 2020 r. TOR BAND nagrał serię utworów o mówiących tytułach: Mb - не „нароgeц”! (Nie jesteśmy „gorszym sortem narodu”!) ${ }^{30}$, Жыве (Niech żyje) ${ }^{31}$, Выборы (Wybory) ${ }^{32}$, Ухоgи!!! (Odejdź!!!) ${ }^{33}$, Кто, если не ты?! (ros. Kto, jeśli nie ty?!) ${ }^{34}$. Członkowie grupy postawili sobie za cel utwalenie przełomu w mentalności Białorusinów ${ }^{35}$. W ich opinii białoruskie społeczeństwo dojrzało do zmian, uwolniło się spod wpływu pociągającego za sznurki „szalonego lalkarza” (ros. больной кукловоg) ${ }^{36}$. Jak śpiewają, do odzyskania wolności potrzeba odwagi i aktywności (Дай же руку мне и вставай с колен / Я свобоgу поgарю тебе взамен ${ }^{37}$ ), dumy narodowej

26 Naka feat. DZIECIUKI \& „Разбітае сэрца пацана” \& „Петля пристрастия” \& Rostany, ВАМ (стихи Вл. Некляева).

27 Rogal, Жыве, https://youtu.be/g3sfwX4tVil.

28 IOWA, Мечта, https://youtu.be/hKT4I1FdK4U.

29 «Мы меняем сознание люgей» - рогачевский Tor Band, который восхищает белорусов гимнами протеста, https://vrogacheve.ru/16569-my-menyaem-soznanielyudey-rogachevskiy-tor-band-kotoryy-voshischaet-belorusov-gimnami-protesta.html.

30 TOR BAND, Мы - не „нароgец”!

31 TOR BAND, Жыве, https://youtu.be/kIWm08f6Uzl.

32 TOR BAND, Выборы, https://youtu.be/p8qAmaNpMNE.

33 TOR BAND, yxogn!!!, https://youtu.be/qHDajlCmoxA.

34 TOR BAND, Кто, если не ты?!

35 «Мы меняем сознание люgей» - рогачевский Tor Band, который восхищает белорусов гимнами протеста, https://vrogacheve.ru/16569-my-menyaem-soznanielyudey-rogachevskiy-tor-band-kotoryy-voshischaet-belorusov-gimnami-protesta.html.

36 TOR BAND, Мы - не „нароgец”!

37 ros. Podaj mnie rękę i wstań z kolan / Wolność dam ci w zamian, TOR BAND, KTO, если не ты?! 
i solidarności społecznej (С верой в серgцах, gержим мы строй. Знамя свобоgы наg головой) 38 .

Na drodze do wolności Białorusinów (Скінем кайgаны мы ${ }^{39}$ ) stoi autorytarny reżim (Выборы без выбора / Что-то нам менять пора ${ }^{40}$ ) i autorytarny przywódca, który nie ma poparcia i zaufania społeczeństwa (Ухоgи! Это воля белорусов!) ${ }^{41}$.

Od czerwca do grudnia 2020 r. poszczególne utwory TOR BAND miały w serwisie YouTube od ok. 500000 do 1700000 wyświetleń. Popularność grupy niewątpliwie wpływa na zasięg oddziaływania przekazywanych przez nią treści, co z kolei prowadzi do zmian postaw i preferencji politycznych Białorusinów.

\section{Wujku Saszo, bez obrazy $y^{42}$}

Analiza utworów powstałych w czasie kampanii i po wyborach prezydenckich (w sierpniu 2020 r.) pozwala zrekonstruować artystyczną diagnozę stanu społeczeństwa oraz swoisty plan działań muzycznych na rzecz jego mobilizacji. Niedługo przed wyborami pojawiło się sporo pieśni - manifestów politycznych, które były reakcją na bieżącą sytuację w Białorusi ${ }^{43}$. Artyści zaapelowali o „przeliczenie się", sugerując początkowo, że ludzi dążących do zmian jest mało, ale są: Нас мало, но есть! $!^{44}$, aby wkrótce skonkludować, że są to miliony wspaniałych osób: Нас миллионы... Мы все уникальны... ${ }^{45}$. Uwagę twórców zdominowały następnie pozytywne emocje związane z rosnącą aktywizacją i solidarnością społeczeństwa, a także nadzieja, którą niosły zbliżające się wybory ${ }^{46}$.

38 ros. Z wiara $w$ sercach, równamy w szeregu. Flaga zwycięstwa powiewa nad głowami. TOR BAND, Mы - не „нароgец”!

39 błrus. Zrzucimy kajdany. Tor Band, Жыве.

40 ros. Wybory bez wyboru / coś już pora zmienić. TOR BAND, Выборы.

${ }^{41}$ ros. Odejdź! Taka jest wola Białorusinów! TOR BAND, Уходи!!!

42 AP\$ENT, Песенка весёлого белоруса, https://youtu.be/ykppO49lapw.

43 Litesound, Беларускаму люgy, https://youtu.be/SE2p5iJBcTs; Каця Пытлева, Ілля Маліноўскі, Угляgзіся, https://youtu.be/-Y4-J6u1GpY; Naka feat. DZIECIUKI \& „Разбітае сэрца пацана” \& „Петля пристрастия” \& Rostany, BAM.

${ }^{44}$ ros. Jest nas mało, ale jesteśmy. Аня Шаркунова, Песня счастливых люgей, https:// youtu.be/-5X_z7dajBg.

45 ros. Są nas miliony i jesteśmy niepowtarzalni. Аня Шаркунова, Песня счастливых люgей.

46 Można tu wymienić dodatkowo: Partyzanski praspekt, Чapгa, https://youtu.be/ MhK2WoXwMPO; GoodVibe BY, Bce BMECTE Mы, https://youtu.be/_KXDrRu8BsY; 
Motywem przewodnim utworów w okresie przedwyborczym stała się krytyka „Baćki” i stworzonego przezeń autorytarnego systemu. Państwo oparte na aparacie przemocy sięgnęło dna - głosiła pieśn роДНОй край grupy AP\$ENT. Tytuł utworu to gra słów (w transliteracji „roDNOj kraj” to kraj ojczysty, ale wyróżnione wersalikami „DNO” wskazuje zarazem na jego krytyczne przesłanie ${ }^{47}$ ). Autor kolejnej pieśni, weteran walki z systemem Łukaszenki, muzyk i poeta Lawon Wolski, współtwórca głośnego w latach 90. projektu muzycznego Незалежная Рэспубліка Мроя ${ }^{48}$ (Ludowa Republika Marzeń) kultowej grupy N.R.M., obecnie nagrywający jako „Volski”, przekonuje dodatkowo, że ten system, zżarty przez rdzę, jest już nie do uratowania ${ }^{49}$. W tym ujęciu reżim Łukaszenki staje się ofiarą własnej kłamliwej propagandy, w którą nie wierzą ani propagandziści, ani obywatele ${ }^{50}$.

Nie dziwi więc prostolinijny zwrot członków zespołu AP\$ENT do prezydenta. Utrzymana w gatunku „wiejskiego rocka” Песенка весёлого белоруса (ros. Piosenka wesołego Białorusina) to prośba do Alaksandra Łukaszenki (Wujka Saszy), żeby (bez obrazy) zabrał ze sobą ciotkę Lidię (Lidię Jarmoszynę, która od 1996 r. jest przewodniczącą Państwowej Komisji Wyborczej) z powrotem do piekła:

Дяgя Саша, без обия но вам никто не раg забирайте тётю Лияу возвращайтесь в $а g^{51}$.

BarRokka, Вясновая, https://youtube/26JLI56KgW0; Place to Be, Мая Перамога, https:// youtu.be/zJpU5iS5g98.

47 AP\$ENT, роДНОй край, https://youtu.be/jNOYHie2AhY.

48 Państwo miało swoją wirtualną ambasadę, a fani zespołu mogli starać się o obywatelstwo kraju: https://web.archive.org/web/20041207192110/. Jak zauważają w komentarzach do wideoklipu fani Volskiego, N.R.M. słuchali jeszcze w szkole. Maja nawet paszport Ludowej Republiki Marzeń, który wkrótce może się przydać. Volski, Iržavaja dziaržava, https://youtu.be/7FEUZy78Tps.

49 błrus. Przerdzewiałe państwo / Pije swą truciznę / Ani żal, ani pożar / Nic jej nie uratuje. Volski, Iržavaja dziaržava.

50 Па вушы уу хлусьні. / Сабе не вераць самі, / Каго зь іх не вазьмі. // Яны чытаюць мантру: / „ніgзе няма іржы!” / Але ўсе ўсё бачаць / Кажы ці не кажы (błrus. Po uszy w kłamstwie, / Sami sobie nie wierza, / Każdy jeden / Powtarza jak mantrę: / „Nie ma żadnej rdzy!” / Ale wszyscy ją widzą - / Cokolwiek mówia). Volski, Iržavaja dziaržava.

51 ros. Wujku Saszo, bez obrazy, / Ale nikt tu cię nie lubi / Zabieraj ciotkę Lidię / Wracajcie do piekła. AP\$ENT, Песенка весёлого белоруса. 
Prześmiewcze utwory mają psychologiczną, terapeutyczną funkcję: przełamują strach, pozwalają odreagować absurdalność systemu, pozytywnie nastrajają do działania. Humor jest znakomitym środkiem do przełamywania oficjalnej narracji poprzez deformowanie i ośmieszanie propagandowych haseł. Łukaszenka, „ojciec narodu”, w cytowanej piosence reprezentuje „siły zła”, co jest nawiązaniem do zimnowojennej propagandy o walce imperiów dobra i zła.

Absurdalność rządów Łukaszenki pokazują też poruszane przez muzyków aktualne wątki pandemii (Białorusini mogą się tylko myć i modlić52) czy ciągłego straszenia społeczeństwa agresją Zachodu, co ma przesłonić bieżące problemy kraju (местный Армагеgон - ну и что, абы не было войьь5).

Śmiech, podobnie jak muzyka, wzmacnia determinację społeczeństwa. Zauważają to internauci: w komentarzach do utworów muzycznych z czerwca 2020 r. pojawiają się opinie na temat rozpoczynającej się aksamitnej rewolucji. Takie pieśni stymuluja do tego, by iść do końca. Pora zrzucić Łukasza z jego tronu, sinymi palcami już się nie utrzyma ${ }^{54}$.

Pieśni towarzyszące wydarzeniom z wiosny 2020 r. - akcjom zbierania podpisów niezbędnych do rejestracji kandydatów w wyborach oraz wielotysięcznym mityngom poparcia Swiatłany Cichanoǔskiej - niewątpliwie były przejawem chęci organizowania emocji społecznych i skłonienia Białorusinów do refleksji nad sytuacją kraju. Artyści zauważali z satysfakcją, że podejście ludzi do problemów kraju się zmieniło: z zastraszonych, bojących się wyróżnić z tłumu, niechętnych do podjęcia działania członków społeczeństwa, wraz z upływem czasu, rejestracją kandydatów i zbliżającymi się wyborami, mimo strachu stali się zaangażowanymi, świadomymi obywatelami ${ }^{55}$.

Mohylewski zespół Nizkiz uchwycił w utworze Правілы (błrus. Zasady) cel Białorusinów, którzy wyszli spontanicznie, ale drogę wytyczyła im wzniesiona przez kogoś flaga narodowa:

Мы выйшлі на вуліцу, і кожны з нас

Не веgаў, куgы ісці, напэўна, праз

52 AP\$ENT, Мылю и молюсь, https://youtu.be/U3BUZUdjRWE.

53 ros. Mamy tu lokalnie Armagedon, no i co z tego? Żeby tylko nie było wojny. AP\$ENT, Песенка весёлого белоруса.

${ }^{54}$ AP\$ENT, Песенка весёлого белоруса.

${ }^{55}$ Мы gыхаем зноў / Мы gыхаем зноў / Спалоханыя, бяскрылыя / Ці вартыя гэтай gолі мы / Дыхай свабоgна, мілая (błrus. Znów oddychamy, / Znów oddychamy, / Wystraszeni, pozbawieni skrzydet / Czy zasłużyliśmy na taki los / Oddychaj miła pełną piersiq̨). Уладзімір Пугач \& Лявон Вольскі, Дыхаем зноў, https://youtu.be/My6WZiuOWiY. 
Гаgзіну згубіліся б, але ж хтосць узgыме сцяг

Мы выйшлі на вуліцу знянацку так ${ }^{56}$.

Zgodnie z przesłaniem muzyków był to symboliczny moment, w którym została przekroczona granica mentalna Białorusinów oraz nastąpił moment ich przebudzenia się z marazmu i pojawienia się woli walki z rzeczywistością polityczną: Зрабіць штосьці важнае, а не абяцаць! / Такія вось траблы, трабль5 ${ }^{57}$. Wątek ten pojawia się w wielu pieśniach. TOR BAND uwypukla go, zaznaczając, że po latach życia w systemie autorytarnym Białorusini uwolnili się od strachu: Итак боялся столько, Что к нему иммунитет ${ }^{58}$ i teraz mogą mu się przeciwstawić z podniesionym czołem: Узgымай твар, уверх пагляgзі, хопіць трываць ${ }^{59}$.

Akcentowana jest przy tym zmiana systemu wartości społeczeństwa białoruskiego (И система коорgинат уже настроена по-gругому ${ }^{60}$ ) przy zachowaniu tradycyjnego przywiązania Białorusinów do kraju: мы хотим с новым рассветом проснуться зgесь и сейчас ${ }^{61}$.

Mobilizując do działania, artyści apelują o determinację: teraz albo nigdy (Иначе никогДА ${ }^{62}$ ). Ostrzegają przed skutkami zaniechania protestu (И ближе, и ближе, и сgелай же что / Чтобы хуgа не произошло ${ }^{63}$ ) - utratą jakiegokolwiek głosu w sprawach politycznych (Но ежели сегоgня промолчу я - / Утрачу голос навсегga! $\left.{ }^{64}\right)$.

56 błrus. Wyszliśmy na ulice, i każdy z nas / Nie widział dokąd iść, na pewno w poprzek / Godzinę błądziliśmy, ale wtedy ktoś wzniósł flage / Wyszliśmy na ulicę znienacka tak. NIZKIZ, Правілы.

57 błrus. Zrobić coś ważnego, nie tylko obiecywać / Takie właśnie problemy, problemy. NIZKIZ, Правілы.

58 ros. Tyle się już bałem, że mam już na to odporność. AP\$ENT, Я не боюсь, https:// youtu.be/rjt5Ocbjl-g.

59 błrus. Podnieś głowę, patrz w górę, starczy trwać. TOR BAND, Роgная Зямля, https://youtu.be/fMoJApvluLU.

60 ros. I system wartości ustawiony jest już inaczej. Place to Be, На нашей стороне время (H.H.C.B.), https://youtu.be/PTSkR2yzJwg.

61 ros. Chcemy następnego ranka obudzić się tu i teraz. Виталий Артист, Созвезgие, https://youtu.be/0BY2zQrIGrQ.

62 ros. Jak nie teraz, to nigdy, DRUM ECSTASY \& POMIDOROFF, Мapш, https:// youtu.be/U6Ixcq_DQPE.

63 ros. Jest coraz bliżej, bliżej, więc zróbże tak / Aby nie stało się jeszcze gorzej. Макс Корж, Тепло, https://youtu.be/-4pOLJaleSM.

64 ros. I łatwiej byłoby zamilknąć, czując zagrożenie / Lecz - jeśli dziś przemilcze ja / Utrace głos na zawsze. Александр Баль, На роgине моей беga, https://youtu.be/ UAbxtfSOl-4. 
W wielu pieśniach apeluje się o dokonanie wyboru między odwagą a tchórzostwem (Время смелым быть или вновь молчать. / Этот выбор серgца gолжен прозвучать $\left.{ }^{65}\right)$. Apel ten zyskuje udramatyzowany obraz w wideoklipie do utworu: Кто, если не ты?! (pol. Kto, jeśli nie ty?!) zespołu TOR BAND. Na początku nagrania do funkcjonariuszy sił porządku zwracają się dzieci, alegorycznie wskazując, że atak na protestujących rodziców jest w istocie napaścią na kolejne pokolenia, którym odbiera się prawo do wolności66.

\section{Starczy żyć jak w gościach, tu jest twój język, tu flaga ojczysta ${ }^{67}$}

Będący „głosem narodu” artyści wytyczają (a właściwie twórczo przetwarzają) oczekiwania protestujących i ich cele. Przedstawione żądania nie są wygórowane: społeczeństwo dąży do normalności, pragnie żyć „u siebie”, chce decydować o sprawach swojego kraju. Artyści pokazują trapiące Białorusinów problemy i bolączki (Мову знішчалі, а яна уусё жыве ${ }^{68}$ ). Uświadamiają znaczenie odrębnych wartości i symboli narodowych, bez których Białorusin czuje się gościem we własnym kraju: Хопіць жыць так, быццам у гасцях, вось твая мова, вось ролны сцяг 69 .

Kształtowanie wspólnoty i nowoczesnej tożsamości kulturowej Białorusinów odbywa się więc w ramach odrębnych białoruskich kodów kulturowych dotyczących języka, tradycji, historii i bohaterów. Zgodnie z tymi kodami sowiecki mit wielkiej wojny ojczyźnianej został zbiałorutenizowany przez tradycję partyzancką $^{70}$, korzenie tożsamości białoruskiej leżą w Wielkim Księstwie Litewskim a nie w Białoruskiej SRR, zaś punktem odniesienia w przekazie muzycznym jest honor i odwaga naszych przodków ${ }^{71}$.

Redefiniowana jest również „tutejszość", która staje się instynktem samozachowawczym, świadomym wyborem motywowanym dumą z korzeni, przodków

65 ros. Czas być odważnym albo znów milczeć / Ten wybór serca musi w końcu wybrzmieć. TOR BAND, Кто, если не ты?!

66 Ibidem.

67 TOR BAND, Роgная Зямля.

68 błrus. Język niszczyli, a on wciąż żyje. TOR BAND, Роgная Зямля.

69 błrus. Starczy żyć jak w gościach, tu jest twój język, tu flaga ojczysta, TOR BAND, Роgная Зямля.

70 Піт Паўлаў, Вараны Коню, https://youtu.be/jqRVkNdS7Kw.

71 Stary Olsa, Szturm zamku Pulen, https://youtu.be/yFlYudGmNe8. 
i tradycji. Tradycja ta: zapach siana, pot konia, gościnność ludzi (Частавалі б яны нас шчыра соллю з хлебам²) nabiera szczególnego znaczenia, gdy jako własną przedstawia ją śpiewak operowy, baryton Ilja Silczukoǔ.

Poszukiwaniu korzeni służy częste nawiązywanie do twórczości białoruskich wieszczy, m.in. Franciszka Bohdanowicza, Jakuba Kołasa czy Janki Kupały, którzy są patronami protestujących ${ }^{73}$. Odwołując się do Wszechmogącego Boga ${ }^{74}$ jak Natałła Arsieniewa, artyści proszą o ratowanie przyrodzonego języka ojczystego, znanego z dzieciństwa (Я з маленства так прывык ${ }^{75}$ ). Wspominają, że utwory Franciszka Bahdanowicza i Jakuba Kołasa czytała im babcia, a wiersz: A kto tam idzie? Janki Kupały znali na pamięćc76. Uczą, że mimo podejmowanych przez zmieniające się władze działań polonizacyjnych i rusyfikacyjnych, język przetrwał: Мову знішчалі, а яна ўсё жыве ${ }^{77}$. Podkreślają, że język jest elementem odróżniającym „swoich” od „obcych”, narzędziem budowania świadomości narodowej i wspólnoty białoruskiej:

Мова родная мая, словы-асалоgа,

Без цябе кім быў бы я, што было б з нароgам?78

Sprawa języka i tożsamości białoruskiej jest jednak bardziej skomplikowana, co unaoczniają choćby cytowane w niniejszym artykule fragmenty tekstów utworów muzycznych w języku rosyjskim. Protesty z 2020 r. potwierdzają, że również te utwory - choć napisane po rosyjsku - niosą białoruską treść kulturową. Stąd wniosek, że kulturową i obywatelską emancypację, patriotyzm i poczucie narodowej odrębności, tj. zbiorową tożsamość Białorusinów, można wzmacniać zarówno po białorusku, jak i po rosyjsku. Można to robić także w trasiance, którą młode, wykształcone autorki projektu Arystokratyczna bladość ${ }^{79}$ sytuują w połowie drogi do nabycia kompetencji w zakresie białoruskiej mowy.

72 błrus. Częstowaliby oni nas szczerze chlebem z solq̨. Ilya Silchukoŭ, Mova, https:// youtu.be/opFOeDLfQVM.

73 błrus. Kupała i Kołas idą z nami / Będą z nas dumni. Проект 4.0.4, Новая Раніца, https://youtu.be/VQUEMUGR5dE.

74 Botanic project, Ратуй, https://youtu.be/VU4Q8TzvrVw.

75 błrus. Od dzieciństwa przywykłem. Ilya Silchukoŭ, Mova.

76 Botanic project, Ратуй.

77 błrus. Język niszczyli, a on wciąż żyje. TOR BAND, Рogная Зямля.

78 błrus. Mowo moja rodzima, osłodo słów / Kim bez ciebie byłbym ja, co byłoby z narodem? Ilya Silchukoŭ, Mova.

79 Інтэрвію з gуэтам Арыстакратычная блеgнасць, https://youtu.be/Vgly1Docnao. 
Wiele pieśni wyjaśnia symbolikę protestu, którą niosą biało-czerwono-biała flaga i herb Pogoń. Taka symbolika jednoczy, ale zarazem świadczy o świadomym wyborze trudnego wolnościowego szlaku ${ }^{80}$.

Jednocześnie jednak „barwy wolnej Białorusi”, zdominowane przez biel i czerwień, nadały protestom estetyczny sznyt. Uczestnicy nosili biało-czerwono-białe ubrania, przypinali wstążeczki i mieli bukiety kwiatów w tych kolorach, manifestując na różne sposoby artystyczny wymiar protestu i chęć zaznaczenia niezgody na oficjalną symbolikę państwową. Nie trzeba dodawać, że symbolika niesiona przez barwy biało-czerwono-białej flagi jest także zawarta w większości wideoklipów.

\section{Dla wrogów narodu - wrogiem jest naród ${ }^{81}$}

Kontrast między obrazem rzeczywistości w omawianych utworach muzycznych a narracją oficjalną uwypukla zwłaszcza motyw przemocy. W niektórych nagraniach rzeczywistość udokumentowano wprost. Często pokazywany jest w nich moment śmierci Alaksandra Tarajkowskiego i inne drastyczne sceny przemocy z udziałem bohaterów protestów (np. kadr, na którym uchwycono moment odbierania flagi Ninie Bahińskiej82 czy inny, głośny - przedstawiający aresztowanie nieprzytomnego Jaŭhena Zaiczkina, nad którym stoi zdezorientowany OMON-owiec) ${ }^{83}$.

Nasuwa się wniosek, że stosowanie nieuzasadnionej przemocy, brak refleksji i bezkrytyczne wykonywanie rozkazów zbliża sposób zachowania białoruskich mundurowych do sposobu działań stalinowskiego aparatu represji ${ }^{84}$.

Jednocześnie artyści szkicują obraz prawdziwej służby na rzecz państwa, służby chwalebnej, która polega na ochronie społeczeństwa, a nie bezmyślnym wykonywaniu przestępczych rozkazów ${ }^{85}$.

80 Пирятин, Чырвоная і Белая, https://youtu.be/Ns8WJeRIMSY; Анжаліка Агурбаш, Наўзgагон (2020).

81 Volski, Ворагі нароgy, https://youtu.be/QCnT8vbRRJo.

82 Люgи решили, что мужчина с фото с силовиком из Минска умер. Но выяснилось, что на виgео был gругой человек, https://medialeaks.ru/1008tat-protesti-vbelarusii/.

83 Raspatory, Stop Terror, https://youtu.be/pbVLYdmTfig.

84 NEMIGA, Самый белый цветок, https://youtu.be/1CnUv5GCqAM.

85 ДОМ Связи, Ты gо работы еgешь только в штатском, https://youtu.be/QMyBvKdtwU. 
Bezmyślni milicjanci przypominają zombie, których celem jest zlikwidowanie jak największej liczby przeciwników ${ }^{86}$, a brak honoru mundurowych jest wprost proporcjonalny do zer na banknotach (Отсутствие чести пропорционально нулям от gенежных знаков $\left.{ }^{87}\right)$. Pozbawieni kręgosłupa moralnego „oni” są gotowi sprzedać honor i sumienie za fałszywe medale ${ }^{88}$.

Takie przykłady można mnożyć. Warto jednak wskazać wspólny projekt artystów alternatywnych (m.in. Кастян, Wally, Глеб BFI, Igor Maele, Diez, MA:RA, Alex iJi, Razor in Pussy, Потрачено.FM) pod nazwą АБЫHEMEHТ [ABYNEMENT], która zawiera grę słów („aby nie mient”): „mient” w języku białoruskim oznacza 'milicjant'. Projekt, który w zamierzeniu miał symbolizować solidarność białoruskich muzyków i głos wolnej Białorusi ${ }^{89}$, został oparty na antagonistycznych obrazach: ludzi o jasnym spojrzeniu, maszerujących pod biało-czerwono-białą flagą (чысціня у вачах, бел-чырвона-белы сцяг $2^{90}$ ) i nawołujących do budowania solidarności społecznej oraz „obcych”, „złych” - OMON-owców w kominiarkach, którzy mają krew na rękach. Muzycy stojący po stronie bezbronnego społeczeństwa przewidują, że ci źli będą ofiarami opartego na kłamstwie systemu (Рукамі пропаганgы заgушыш сам сябе ${ }^{91}$ ).

Przywołany tu obraz „wroga narodu i faszystowskiej bandy” to przekodowany, odwrócony obraz łukaszenkowskiej propagandy. Prawdziwymi wrogami narodu są ci, którzy posługują się metalowymi tarczami, mają granaty i armatki wodne, wsadzają za kraty niewinnych ludzi.

W ten sposób utarte slogany propagandowe zyskują nowe opozycyjne znaczenie: dla prawdziwych wrogów narodu, wrogiem jest naród. O tego rodzaju „wykluczeniu wykluczających” przekonująco zaśpiewał Lawon Wolski: Для ворагаў нароgу вораг - нароg ${ }^{92}$.

86 ДАЙ ДАРОГУ!, Баю-Бай, https://youtu.be/-vbnfNBMXgQ.

87 ros. Brak honoru jest wprost proporcjonalny do zer na środkach płatniczych. Place to Be, Право на Свет, https://youtu.be/yR22-XDmvcQ.

88 TOR BAND, Роgная Зямля, https://youtu.be/fMoJApvluLU.

89 АБЫНЕMЕНТ, Бел-Чырвона-Белы, https://youtu.be/BN1CXGXOWMk.

90 błrus. Czystość w oczach, biało-czerwono-biała flaga. АБЫНЕМЕНТ, Бел-ЧырвонаБелы.

91 błrus. Rękami propagandy sam się udusisz. АБЫНЕМЕНТ, Бел-Чырвона-Белы.

92 błrus. Dla wrogów narodu wrogiem jest naród. АБЫНЕМЕНТ, Бел-Чырвона-Белы. 


\section{Nieroby, prostytutki, narkomani $9^{93}$}

Ważnym celem muzyki buntu jest również demaskowanie oficjalnej manipulacji, przedstawiającej protestujących jako degeneratów, prowadzących kraj do upadku. Ich działania są jakoby koordynowane zewnętrznie przez obce państwa, które dążą do destabilizacji sytuacji w Białorusi. Wypowiedzi na ten temat można było usłyszeć z ust Łukaszenki zarówno w trakcie kampanii, jak i później - podczas marszy protestacyjnych. Kontestujący muzycy szydzą z szefa państwa, przytaczając jego opinie:

Запаgные кукловоgы поражены,

Уже месяц мы шастаем по улицам страны. [...]

Я ничего не сgелал, но мне все должны.

Не могу дождаться развала страны ${ }^{94}$.

Na podstawie wypowiedzi Łukaszenki oraz przekazów medialnych muzycy zrekonstruowali krytyczny obraz współobywatela, nieinteresującego się losami kraju, wiernopoddańczo i bezrefleksyjnie podążającego za władzą:

Копыта почищу, картохи нажрусь,

Гісторыю ня знаю, но Жыве Беларусь ${ }^{95}$.

Odwrócenie oficjalnej narracji następuje poprzez humor i wyszydzenie oraz rzekomą jej aprobatę:

Мне не досталось в сизо синяков,

Краску куплю - и к фейкам готов!96

Taka karnawalizacja prowadzi do swoistego katharsis - oczyszczenia z negatywnych emocji i dowartościowania wykluczonych przez władze protestujących oraz wszystkich obywateli, którzy byli ośmieszani przez rządzących i ich media.

93 Place to Be, За Беларусь, https://youtu.be/dODKqHWrdd4.

94 ros. Zachodni lalkarze są pod wrażeniem, / Już miesiąc zajmujemy się po ulicach łażeniem. [...] Nic nie zrobiłem ale wszystko mi się należy / Nie mogę się doczekać rozpadu macierzy. Place to Be, За Беларусь.

95 ros. Kopyta umyję, kartofli nażrę się / Historii nie znam, niech żyje Białoruś. Place to Be, За Беларусь.

96 ros. Byłem w areszcie, ale nie mam siniaków / Kupię więc farbę i zrobię fejk. Place to Ве, за Беларусь. 
Potępiani wykluczeni tworzą swoistą „rodzinę wykolejeńców”: narkomanów, alkoholików, prostytutek, przywiezionych pociągami z Polski ${ }^{97}$, wszystkich, którzy „postanowili się wspólnie przespacerować”:

Тунеяgцы, проститутки, наркоманы -

Это всё мои братаны, я вечно пьяный ${ }^{98}$.

W przekazie muzyków przynależność do „rodziny” wykluczonych nobilituje: są tu osoby kreatywne, pozytywne, kierujące się zasadami etycznymi. Kreowane przez oficjaną narrację podziały społeczne („patriota” vs. „szkodnik”) są wywrócone na opak: szkodnikami i wrogami narodu są Łukaszenka i jego ludzie, a patriotami - niezgadzający się na narzucony porządek Wojownicy Słońca, współcześni dekabryści (Декабристы новой эпохи ${ }^{99}$ ), miliony ludzi z wielkim sercem (Миллионы больших серgец ${ }^{100}$ ), przepełnionym duchem wolności (Свабоgы gyх у нашых сэрцах ${ }^{101}$ ):

Нібы сонца ваяры,

праўgай свецімся знутры.

Тое, што тваё - бяры.

I трымай гэтак моцна, як сваё сонца ${ }^{102}$.

Stale powracającym w pieśniach oporu motywem jest siła wspólnoty. Poczucie wspólnoty przybliża cel protestu: Мы нараgзіліся вольнымі быць ${ }^{103}$. Siła wspólnoty jest niepokonana: Разам мы ${ }^{104}$, Толькі уссе разам¹05, Толькі разам06:

97 AP\$ENT, Грибник, https://youtu.be/tDovMuCiD-I.

98 ros. Nieroby, prostytutki, narkomani - / To sq moi bracia - jam wciąż pijany. Place to Be, за Беларусь, ор. cit.

99 ros. Dekabryści nowej epoki. LOUNA, Станем стеной, https://youtu.be/-UhKASGMYa4.

100 ros. Miliony wielkich serc. NAVIBAND, Миллионы больших серgец, https://youtu. be/DSzOfQB-iaA.

101 błrus. Duch wolności jest w naszych sercach. Анжаліка Агурбаш, Наўзgагон (2020).

102 błrus. Jak wojownicy słońca, / prawda lśni od wewnątrz. / Co twoje - bierz. / I trzymaj się mocno jak słońce. Maria Ermakova, Сонца Ваяры, https://youtu.be/Blf4HSTdVu4.

103 błrus. Urodziliśmy się by być wolnymi. TOR BAND, Роgная Зямля.

104 błrus. Jesteśmy razem. VAL, Навечна, https://youtu.be/kBZJg-NaVIc.

105 błrus. Tylko wszyscy razem. Александр Сериков, Усе разам, https://youtu.be/ kMQI6UXA230.

106 NGe, Разам, https://youtu.be/ERmslzij4C4. 
Веgь если всех нас собрать по камням Мы станем стеной ${ }^{107}$.

Wspólnota oporu i solidarność społeczna są wartościami, których nie da się przecenić: budzą szacunek, współpracę, radość odbiorców. Prowadzi to do wniosku, że pieśń protestu buduje nowy paradygmat relacji społecznych, opartych na jedności, wspólnocie i poczuciu przynależności narodowej:

Я - беларус! / Я - не боюсь, / Не отступлю / И не отрекусь ${ }^{108}$.

Мы - беларусы, мы з мірам іgзем / У светлы і сонечны пуць ${ }^{109}$.

мы не быgло, стаgо, трусы, мы живой нароg Беларусы $1^{110}$.

We wspólnocie tej, a także w ogóle w wydarzeniach z 2020 r., wyjątkową rolę odegrały kobiety. Ikoną białoruskich protestów stała się Nina Bahińska, siedemdziesięciotrzyletnia emerytka, geolożka, nazwana przez włoską redakcję czasopisma „Vogue” matkq białoruskich protestów ${ }^{111}$. Internet obiegła scena z jej udziałem, w której funkcjonariusze OMON-u próbowali jej odebrać biało-czerwono-białą flagę. Kobieta wyrwała się im, powiedziała, że „spaceruje”112 i poszła dalej. Jej odpowiedź brzmiąca „spaceruję” stała się jednym z najpopularniejszych haseł protestu (\#ягуляю).

Hasło to podchwycili muzycy grupy PyLai, którzy w uznaniu dla kobiet zauważają przewrotnie, że kobiety wcale nie „spacerują” (ros. Женщины не гуляю). Podkreślając ich rolę, muzycy zaznaczają, że biały protest stał się najbardziej dramatycznym i zarazem inspirującym momentem zwrotnym wydarzeń z 2020 r. Jak wyjaśniają, kobiety nie tyle spacerują, co „odprowadzają” - obalają stary reżim, w zastępstwie za przebywających w aresztach mężczyzn ${ }^{113}$.

107 ros. Przecież jeśli każdy z nas będzie cegiełką / To staniemy się murem. LOUNA, Станем стеной.

108 ros. Jestem Białorusinem! / Nie boję się, / Nie wycofam się / Nie wyrzeknę się. Долбушина и Пугач, Я - БЕЛАРУC!, https://youtu.be/tV-ycKL3tol.

109 błrus. My Białorusini idziemy w pokoju / w jasna i słoneczna drogę. «Разбуры турмы муры». Спяваюць Сяргей Kosmas і Сяргей Ціханоўскі, https://youtu.be/ FQz3NazwkUc.

110 ros. Nie jesteśmy bydłem, stadem, tchórzami - jesteśmy żywym narodem - Białorusinami. TOR BAND, Мы - не „нароgец”!

111 https://www.reddit.com/r/europe/comments/j2rmlg/nina_baginskaya_mother_ of_the_belarusian/.

112 «Я гуляю» сказала Нина Багинская, https://youtu.be/be9-CkQ2zuk.

113 PyLai, Женщины не гуляют, https://youtu.be/vXuJ_DcDbmQ. 
Wyróżniające się spokojem, ale zarazem stanowczością, pokojowe akcje kobiet, będące przeciwieństwem brutalnych akcji funkcjonariuszy porządku, uwarunkowały popularność metafory o kobiecej twarzy protestów białoruskich, które nazywano także Rewolucją kobiet. Polskiej noblistce Oldze Tokarczuk nasunęło to często później przytaczane stwierdzenie, że wolna Białoruś jest kobietą ${ }^{114}$.

\section{Zakończenie}

Pieśni tworzone poza oficjalnym nurtem, przez środowiska niezależnych artystów, sprzyjają tworzeniu kultury białoruskiego buntu i opowiadają o wartościach uniwersalnych: o pragnieniu wolności i niepodległości, o białych plamach w historii i zakazanych bohaterach narodowych. Wzmacniają ponadto ducha walki i integrują wokół wspólnych celów. Wspólnym mianownikiem tej twórczości jest dziś opowieść o dążeniu Białorusinów do życia w wolności i godności. Zbuntowane przeciwko pozorom wartości społeczeństwo konsoliduje się, a sprzyja temu uświadomienie istnienia wspólnoty „wykluczonych” - przynależności, która jest powodem do dumy. Członkowie tej wspólnoty kierują się określonymi zasadami moralnymi, którymi są solidarność społeczna, postawa obywatelska i świadome uczestniczenie w życiu społeczno-politycznym kraju.

Jest to również odrzucenie oficjalnej narracji białoruskiej propagandy z jej dominującym motywem, którym jest konieczność funkcjonowania „systemu” Łukaszenki dla zachowania stabilności i pokoju społecznego w Białorusi.

\section{Bibliografia}

ABYNEMENT, Bel-Čyrvona-Bely [АБЫHEMEHT, Бел-Чырвона-Белы], https://youtu.be/ BN1CXGXOWMk.

„Â gulâû" skazala Nina Baginskaâ [,Я гуляю” сказала Нина Багинская], https://youtu. be/be9-CkQ2zuk.

Agurbaš Anžalika, Naǔzdagon (2020) [Агурбаш Анжаліка, Науузgагон (2020)], https:// youtu.be/T9UXbViuAxU.

AP\$ENT, Â ne boûs' [Я не боюсb], https://youtu.be/rjt5Ocbjl-g.

AP\$ENT, Gribnik [Грибник], https://youtu.be/tDOVMuCiD-I.

114 O. Tokarczuk, Wolna Białoruś jest kobietą, 9.09.2020, https://wyborcza.pl/7,75399, 26285548,wolna-bialorus-jest-kobieta.html. 
Мы выйшлі на вуліцу знянацку так... Muzyka jako narzędzie budowania...

AP\$ENT, Mylû i molûs' [Мылю и молюсь], https://youtu.be/U3BUZUdjRWE.

AP\$ENT, Pesenka vesëlogo belorusa [Песенка весёлого белоруса], https://youtu.be/ykppO49lapw.

AP\$ENT, RoDNOj kraj [роДНОй край], https://youtu.be/jNOYHie2AhY.

Bal' Aleksandr, Na rodine mоеј beda [Баль Александр, На pogине моей беga], https:// youtu.be/UAbxtfSOl-4.

Band A, Rèvalûcyâ [Рэвалюцыя], https://youtu.be/6T-3qCiByKk.

BarRokka, Vâsnovaâ [Вясновая], https://youtu.be/HqxKmozpJQ4.

Bešlej Ol'ga, Muzyka protestov. Kakie pesni zvučat na ulicah Belarusi, „Nastoâŝee vremâ”

[Бешлей Ольга, Музыка протестов. Какие песни звучат на улицах Беларуси, „Настоящее Время”], 9.09.2020, https://www.currenttime.tv/a/30829355.html [dostęp: 18.06.2021].

Botanic project, Ratuj [Ратуй], https://youtu.be/VU4Q8TzvrVw.

Castells M., Siła tożsamości, tłum. S. Szymański, Warszawa 2008.

Castells M., Społeczeństwo sieci, tłum. M. Marody i in., Warszawa 2007.

DAJ DAROGU!, Ваиิ-Вај [ДАЙ ДАРОГУ!, Баю-Бай], https://youtu.be/-vbnfNBMXgQ.

Dolbušina i Pugač, Â - BELARUS! [Долбушина и Пугач, Я - БЕЛАРУC!], https://youtu.be/ tV-ycKL3tol.

DOM Svâzi, Ty do raboty edeš' tol'ko v štatskom [ДОМ Связи, Ты gо работы еgешь только в штатском], https://youtu.be/QMy-BvKdtwU.

DRUM ECSTASY \& POMIDOROFF, Marš [Mapw], https://youtu.be/U6Ixcq_DQPE.

Duszyk K., Wideoklip jako komunikat medialny. Wartość estetyczna i funkcja, [w:] Komunikacja wizualna w prasie i w mediach elektronicznych, red. K. Wolny-Zmorzyński, W. Furman, J. Snopek, K. Groń, Warszawa 2013, s. 179-197.

Dymna Lotva, Peremen! [Перемен!], https://youtu.be/7QSTip3lpks.

Ermakova Maria, Sonca Vaâry [Сонца Ваяры], https://youtu.be/Blf4HSTdVu4.

Getka J., Darczewska J., Na drodze do wolności. Białoruska partyzantka kulturowa w przestrzeni publicznej i w Internecie. Warszawa 2021.

GoodVibe BY, Vse VMESTE My [Bce BMECTE Mы], https://youtu.be/_KXDrRu8BsY. Ilya Silchukoŭ, Mova, https://youtu.be/opFOeDLfQVM.

ìntèrviû z duètam Arystakratyčnaâ blednasc' [Інтэрвію з gуэтам Арыстакратычная блеgнасць], https://youtu.be/Vgly1Docnao.

IOWA, Mečta [Мечтa], https://youtu.be/hKT4I1FdK4U.

Jabłońska B., O społecznym charakterze muzyki. Szkic socjologiczny, „Pogranicze. Studia Społeczne" 2018, t. 34, s. 113-128.

Jarecka U., Świat wideoklipu, Warszawa 1999.

Jeziński M., Muzyka popularna jako wehikuł ideologiczny, Toruń 2011.

Korž Maks, Teplo [Корж Макс, Тепло], https://youtu.be/-4poLJaleSM.

„Kto, esli ne ty?” Tor Band prezentoval novuû pesnû [„Кто, если не ты?” Tor Band презентовал новую песню], https://nn.by/?c=ar\&i=255097\&lang=ru.

Lâǔčuk Margaryta, Vol'skì Lâvon, Pavetrany šar [Ляўчук Маргарыта, Вольскі Лявон, Паветраны шар], https://youtu.be/WoUh3872Dp8. 
Laudans, Vysnova, https://youtu.be/6OmoOHTXGiO.

Litesound, Belaruskamu lûdu [Беларускаму люgy], https://youtu.be/SE2p5iJBcTs.

LOUNA, Stanem stenoj [Станем стеной], https://youtu.be/-UhKASGMYa4.

Lûdi rešili, čto mužčina s foto s silovikom iz Minska umer. No vyâsnilos', čto na video byl

drugoj čelovek [Люgи решили, что мужчина с фото с силовиком из Минска умер.

Но выяснилось, что на виgео был gругой человек], https://medialeaks.ru/1008tat-

protesti-v-belarusii/.

„My menâem soznanie lûdej” - rogačevskij Tor Band, kotoryj voshiŝaet belorusov gimnami

protesta [„Мы меняем сознание люgей” - рогачевский Tor Band, который восхищает

белорусов гимнами протеста], https://vrogacheve.ru/16569-my-menyaem-soznanie-

-lyudey-rogachevskiy-tor-band-kotoryy-voshischaet-belorusov-gimnami-protesta.html.

N.R.M., Try čarapachi 2020, https://youtu.be/DIXB6YsMASE.

Naka feat. DZIECIUKI \& „Razbitae sèrca pacana” \& „Petlâ pristrastiâ” [„Разбітае сэрца пацана”

\& „Петля пристрастия”] \& Rostany, BAM (stihi VI. Neklâeva) [(стихи Вл. Некляева)],

https://youtu.be/3IsHtOVp1HA.

NAVIBAND, Milliony bol'ših serdec [Миллионы больших серgец], https://youtu.be/DSzOfQB-iaA. NEMIGA, Samyj belyj cvetok [Самый белый цветок], https://youtu.be/oE_4F9wk11w.

NGe, Razam [Разам], https://youtu.be/ERmslzij4C4.

NIZKIZ, Pravily [Правілы], https://youtu.be/SaTOst5utL8.

Partyzanski praspekt, Čarga [Чapza], https://youtu.be/MhK2WoXwMPO.

Pęczak M., „Patriotyzmy” polskiej muzyki popularnej, „Kultura Współczesna” 2014, nr 1 (84).

Pęczak M., Subkultury w PRL. Opór, kreacja, imitacja, Warszawa 2013.

Pirâtin, Čyrvonaâ i Belaâ [Пирятин, Чырвоная і Белая], https://youtu.be/Ns8WJeRIMSY.

Pìt Paǔlaǔ, Varany Konû [Піт Паўлаў, Вараны Коню], https://youtu.be/jqRVkNdS7Kw.

Place to Be, Мaâ Peramoga [Мая Перамога], https://youtu.be/zJpU5iS5g98.

Place to Be, Na našej storone vremâ (N.N.S.V.) [На нашей стороне время (Н.H.C.B.)],

https://youtu.be/PTSkR2yzJwg.

Place to Be, Pravo na Svet [Право на Свет], https://youtu.be/yR22-XDmvcQ.

Place to Be, Za Belarus' [За Беларусь], https://youtu.be/dODKqHWrdd4.

Poczobut A., System Białoruś, Warszawa 2013.

Proekt 4.0.4, Novaâ Ranica [Проект 4.0.4, Новая Раніца], https://youtu.be/VQUEMUGR5dE. Pugač Uladzìmìr, Vol'skì Lâvon, Dyhaem znoǔ [Пугач Уладзімір \& Вольскі Лявон, Дыхаем

зноу], https://youtu.be/My6WZiuOWiY.

PyLai, Ženŝiny ne gulâût [Женщины не гуляют], https://youtu.be/vXuJ_DcDbmQ.

Pytleva Kacâ, Malinoǔski Illâ, Uglâdzisâ [Пытлева Каця, Маліноўскі Ілля, Угляgзіся],

https://youtu.be/-Y4-J6u1GpY.

Raspatory, Stop Terror, https://youtu.be/pbVLYdmTfig.

«Razbury turmy mury». Spâvaûc' Sârgej Kosmas i Sârgej Cihanoǔskì [«Разбуры турмы

муры». Спяваюць Сяргей Коsтаs і Сяргей Ціханоўскі], https://youtu.be/FQz3NazwkUc. Rogal, Žyve [Жыве], https://youtu.be/g3sfwX4tVil.

Šarkunova Anâ, Pesnâ sčastlivyh lûdej [Аня Шаркунова, Песня счастливых люgей], https:// youtu.be/-5X_Z7dajBg. 
Serikov Aleksandr, Use razam [Сериков Александр, усе разам], https://youtu.be/kMQI6UXA230.

Słownik współczesnego języka polskiego, red. B. Dunaj, Warszawa 1996.

Sož, Malako, https://youtu.be/hn2bzjMRJgU.

Stary Olsa, Szturm zamku Pulen, https://youtu.be/yFlYudGmNe8.

Sumarok, Čèrcì [Чэрці], https://youtu.be/c6fgUy_8pbg.

Tokarczuk O., Wolna Białoruś jest kobieta, 9.09.2020, https://wyborcza.pl/7,75399,26285548, wolna-bialorus-jest-kobieta.html.

TOR BAND, Kto, esli ne ty?! [Кто, если не ты?!], https://youtu.be/kQvKA2FAtwc.

TOR BAND, My - ne „narodec"! [Mы - не „нароgeц”!], https://youtu.be/Rai9tQCrRsQ.

TOR BAND, Rodnaâ Zâmlâ [Роgная Зямля], https://youtu.be/fMoJApvluLU.

TOR BAND, Uhodi!!! [Уxogu!!!], https://youtu.be/qHDajlCmoxA.

TOR BAND, vybory [Выборы], https://youtu.be/p8qAmaNpMNE.

TOR BAND, Žyve [Жыве], https://youtu.be/kIWm08f6Uzl.

VAL, Navečna [Навечна], https://youtu.be/kBZJg-NaVIc.

Vitalij Artist, Sozvezdie [Виталий Артист, Созвезgие], https://youtu.be/OBY2zQrıGrQ.

Volski, Boragì narodu [Bopazi нароgy], https://youtu.be/QCnT8vbRRJO.

Volski, Iržavaja dziaržava, https://youtu.be/7FEUZy78Tps.

Volski, Lohkija-lohkija, https://youtu.be/jyo_A46oz5U. 


\section{Elementy białoruskiej kultury muzycznej jako źródło wiedzy historycznej*}

\section{Elements of Belarusian music culture as a source of historical knowledge}

For many years, historical science in Belarus has been in a difficult situation. The Belarusian authorities use it for their own purposes and manipulate historical facts. In order to maintain reliable knowledge and historical memory among Belarusian society, it is necessary to search for new, attractive means of independent historical communication. The aim of this article is to present how elements of Belarusian music culture can be used to popularize a patriotic and national historical narrative.

Ke y w ords: Belarus, historical memory, music culture

Elementy białoruskiej kultury muzycznej jako źródło wiedzy historycznej

Nauki historyczne na Białorusi od wielu lat znajdują się w trudnej sytuacji. Białoruskie władze wykorzystują je do własnych celów i manipulują faktami historycznymi. Aby utrzymać rzetelną wiedzę i pamięć historyczną wśród społeczeństwa białoruskiego, konieczne jest poszukiwanie nowych, atrakcyjnych środków niezależnej komunikacji historycznej. Celem artykułu jest przedstawienie, w jaki sposób elementy kultury muzycznej Białorusi mogą zostać wykorzystane do popularyzacji patriotycznej i narodowej narracji historycznej.

Słowa kluczowe: Białoruś, pamięć historyczna, kultura muzyczna

\section{Wprowadzenie}

W XXI w. ważnym orężem w szerzeniu narodowo-patriotycznej narracji historycznej na Białorusi stała się niezależna kultura, m.in. kultura muzyczna.

* Niniejszy artykuł stanowi skróconą wersję pracy magisterskiej autorki pt. Elementy pamięci historycznej we współczesnej kulturze muzycznej Białorusi (2019), napisanej pod kierunkiem dr. hab. Jerzego Grzybowskiego. 
Na białoruskiej scenie muzycznej można wyróżnić co najmniej kilka zespołów, które swoją twórczość w większym lub mniejszym stopniu związały z tematyką rodzimej historii. Istnieją grupy, które upodobały sobie np. konkretny okres historyczny i tylko do niego się odwołują. Przykładowo do najdawniejszych, jeszcze pogańskich czasów szczególnie chętnie nawiązują zespoły metalowe m.in.: Znich (3ніч), Solntsevort, Litvintroll, Relikt, a z kolei okres średniowiecza upodobały sobie grupy folkowe: Troitsa (Троіца) lub Stary Olsa (Стары Ольса). Są również muzycy wspominający w swoich utworach wydarzenia z dowolnego momentu w dziejach Białorusi - tutaj należy wymienić chociażby barda Siarhieja Sokolau Wojusza oraz raperów z grupy Czerwonym po Białym (Чырвоным па белым) i ich płytę $W$ poszukiwaniu straconego. Zespołem, który prezentuje historię Białorusi w bardziej całościowy sposób, są natomiast punk-folkowe Dzieciuki (Дзецюкі). Niezwykła rozmaitość gatunków muzycznych, dzięki której każdy może znaleźć coś dla siebie, jest jednym z atutów tego sposobu przekazywania treści historycznych. Równie ważna jest różnorodność środków przekazu, które oferuje kultura muzyczna. Celem niniejszego artykułu jest pokazanie, w jaki sposób poprzez kulturę muzyczną można popularyzować niezależną narrację historyczną.

\section{Album muzyczny jako podręcznik do historii}

Jednym z najprostszych sposobów popularyzowania alternatywnej wiedzy historycznej poprzez kulturę muzyczną jest napisanie piosenki przybliżającej wybraną postać lub wybrane zagadnienie z rodzimej historii w sposób polemizujący czy wręcz zrywający z państwową narracją historyczną. Taką drogę wybrały grodzieńskie Dzieciuki. „Robimy to, czego nie robi państwo, które przegrało walkę o propagowanie białoruskości. Chcieliśmy zostać budzicielami, którzy przywrócą młodym ludziom nasze prawdziwe narodowe wartości" - tłumaczył w jednym z wywiadów dla Bielsatu lider grupy Aleś Dzianisau'. Odtwarzając płyty nagrane przez grodnian (Grodzieński harmider / Гараgзенскі гарміgap (2014), Recha / Рэха (2016), Krótka historia Białorusi / Кароткая гісторыя Беларусі ${ }^{2}$ (2017), Radio Grodno / Pagыё Harodnia (2019)) słuchamy piosenek, których bohaterami są:

- waleczny rycerz, który nigdy nie przegrał żadnej bitwy - Dawid Grodzieński (piosenka: Dawid Grodzieński / Давыg Гараgзенскі),

1 J. Biernat, „Dzieciuki” białoruscy punkowcy zakochani w powstańcach styczniowych, 1.05.2013, https://belsat.eu/pl/news/13752/ [dostęp: 22.05.2021].

2 Krótka historia Białorusi jest solową płytą lidera Dzieciuków Alesia Dzienisaua. 
- najsłynniejszy z władców Wielkiego Księstwa Litewskiego, Ruskiego i Żmudzkiego, za panowania którego kraj znajdował się u szczytu potęgi Witold Wielki (piosenka: Witold Wielki / Вітаўт Вялікі),

- ostatni król Rzeczypospolitej Obojga Narodów - Stanisław August Poniatowski (piosenka: Stanisław August Poniatowski / Станіслаў Аўгуст Панятоўскі),

- brzeski szlachcic, znakomity dowódca i inżynier wojskowy a zarazem człowiek przywiązujący wielką wagę do ideałów wolności i tolerancji - Tadeusz Kościuszko (piosenka: Tadeusz Kościuszko / Tаgэвуш Касьцюшка),

- wybitny poeta epoki romantyzmu - Adam Mickiewicz (piosenka: Adam Mickiewicz / Аgaм Міцкевіч),

- klasyk białoruskiej literatury - Maksym Bahdanowicz (piosenka: Maksym Bahdanowicz / Максім Багgановіч),

- działacz polityczny, pionier białoruskiego ruchu wydawniczego - Wacław Iwanowski (piosenka: Wacław Iwanowski / Вацлаў Іваноўскі),

- odważny i waleczny - gen. Stanisław Bułak-Bałachowicz (piosenka: Stanisław Bułak-Bałachowicz / Станіслаў Булак-Балаховіч),

- twórca systemu zapisu białoruskiej ortografii oraz założyciel Białoruskiej Włościańsko-Robotniczej Hromady - Bronisław Taraszkiewicz (piosenka: Bronisław Taraszkiewicz / Браніслаў Тарашкевіч),

- legendarny dowódca, współautor operacji Ostra Brama - major Maciej Kalankiewicz (piosenka: Maciej Kalankiewicz „Kotwicz” / Мацей Каленкевіч „Котвіч').

Są to postaci zdecydowanie mniej chętnie wspominane przez białoruskie władze ${ }^{3}$. Grodzieńscy punkowcy, przywracając pamięć o nich, starają się stworzyć alternatywny kanon bohaterów narodowych. Kanon oparty na osobach, które walczyły o wolność dla ojczyzny, czy też przyczyniły się do rozwoju białoruskiej kultury albo idei narodowej. W tekstach piosenek artyści w skrócie przypominają ich największe osiągnięcia, bardzo też podkreślają, iż są to „prawdziwie białoruscy" bohaterowie: Grodno ma swojego, sławnego, naszego bohatera; nasz książę; nasz brzeski szlachcic; nasz bohater poprowadzi w bój itp. Jeśli zaś chodzi o wydarzenia historyczne, to bardzo ważne miejsce w twórczości Dzieciuków zajmuje Wielkie Księstwo Litewskie. Muzycy przypominają

${ }^{3}$ Obecnie (2021 r.) o: Dawidzie Grodzieńskim, Witoldzie Wielkim, Tadeuszu Kościuszce, Adamie Mickiewiczu, Maksymie Bahdanowiczu, Wacławie Iwanowskim mówi się więcej, lokalne władze budują też pomniki ich upamiętniające. Natomiast muzycy pisali teksty piosenek w 2012 r., kiedy postaci te dopiero ostrożnie wprowadzano do państwowego dyskursu. 
m.in., jak kształtowało się państwo, podkreślając naturalność i dobrowolność procesu łączenia się ziem litewskich i białoruskich (piosenki: Przepaść/Kручa, Unia horodelska / Гароgля наg Бугам). W piosenkach akcentowany jest także białoruski charakter WKL. Grodnianie zwracają też uwagę na burzliwe dzieje państwa litewsko-białoruskiego, pokazując ziemie białoruskie jako teatr działań wojennych, w wyniku których nasza sława przemienia się w XVIII wieku w Wielkie Księstwo Ruin (piosenka: Wojna Północna / Паўночная вайна). Punkowcy nie boją się sięgać i po trudniejsze tematy, skrzętnie pomijane przez oficjalną narrację historyczną, m.in.:

- powstanie z 1863 roku (piosenki: 1863 rok. Pożegnanie z ojczyzna / 1863 гog. Развітанне з Раgзімай, Mużyckaja prawda / Мужыцкая праўga, Czas Kosynierów / Час касінераў),

- białoruski marsz gen. Stanisława Bułaka-Bałachowicza (piosenka: Chłopcy Bałachowcy / хлопцы-балахоўцы),

- powstanie słuckie (piosenka: Słuczczanie / Случчакі),

- represje stalinowskie (piosenka: 1937, Zapomniana mogiła / Забытая магіла),

- zagłada ludności żydowskiej na Białorusi w czasie II wojny światowej (piosenka: Żydzi. Sen 1941 / Жыgы. Сон 1941),

- zbrodnia w Kuropatach oraz spalenie wsi Chatyń (piosenka: Smutne reggaе / Сумнае рэгі),

- białoruskie podziemie antykomunistyczne (piosenka: Leśni Bracia / Лясныя браты),

- wojna w Afganistanie (piosenka: Zima 1980 roku / Зіма 1980 гоga).

Wszystkie wymienione wydarzenia wykonawcy omawiają w swych piosenkach zgodnie ze znanymi faktami. Muzycy, śpiewając o ofiarach represji stalinowskich, jak również o Bałachowcach, Słucczanach czy Leśnych Braciach odważnie walczących o wolność kraju, starają się przywrócić im należną pamięć. Jednocześnie prezentują kolejne, godne wzory do naśladowania. Przegląd wydarzeń wspominanych przez grodzieński zespół może zrodzić pytanie, czy o wszystkim można i wypada śpiewać, np. o spaleniu wsi Chatyń czy Zagładzie Żydów w czasie II wojny światowej. Poruszając jednak bolesne i trudne tematy, muzycy zawsze robią to w bardzo taktowny i subtelny sposób. Piosenki: 1937 rok, Smutne reggae oraz Żydzi. Sen 1941 są chyba najbardziej lirycznymi i spokojnymi piosenkami w wykonaniu tego zespołu. Innym zarzutem, który można skierować w stronę takiej formy przekazu wiedzy historycznej, jest to, iż teksty piosenek są zazwyczaj bardzo zwięzłe. Podają informacje w sposób skrótowy, niekiedy nie do końca oczywisty. W założeniu ma to jednak zachęcić słuchacza do dalszego, samodzielnego już pogłębiania wiedzy. 


\section{Występ muzyczny jako widowisko historyczne}

Bardziej zaawansowaną formą rozpowszechniania niezależnego przekazu historycznego są koncerty muzyczne, które dzięki odpowiednim: repertuarowi, melodii, kostiumom, dekoracjom czy scenografii mogą przemienić się w widowiska historyczne. Za przykład może posłużyć legendarna rock-opera pt. Narodny Albom / Hapogны Альбом. Spektakl muzyczny opowiada historię przykładowego, wielokulturowego białoruskiego miasteczka, które po traktacie ryskim znalazło się w graniach II Rzeczypospolitej. Kanwę rock-opery stanowią wymyślone przez Michała Aniempadystaŭa losy młodych małżonków Zmiciera i Bronisławy Kostków w latach 1918-1939. Krótkie scenki, przerywane piosenkami opisują jednocześnie codzienność innych mieszkańców miasteczka, o różnych: narodowości, wierze i światopoglądzie - Białorusinów, Polaków, Rosjan i Żydów. W efekcie na scenie pojawia się szereg barwnych postaci. Sklepikarz z Wilna - Kazik Piasecki to najbardziej antysowiecki ze wszystkich bohaterów. Jako typowy nacjonalista jest zwolennikiem idei Polski od morza do morza. Z kolei drwal Józik, człowiek prosty i chamowaty", po cichu liczący na rychłe przyjście czerwonoarmistów jest jego ideowym antagonistą. Bolek i Lolek są natomiast polskimi szpiegami. Młodziutka, naiwna Nadzieńka to „Tutejsza”. Zaś profesor Rahojsza, przyjaciel Zmiciera z lat dziecinnych, jest reprezentantem miejscowej inteligencji. Pozostali mieszkańcy miejscowości to: karczmarz, myśliwy i wszechobecny listonosz. Czasami do miasteczka zaglądają także przemytnicy, omijający leśnymi ścieżkami posterunki polskich jednostek ochrony pogranicza $\left(K \mathrm{P}^{5}\right)$ i sowieckich pograniczników. Ich wspólne życie przerywa wkroczenie żołnierzy Armii Czerwonej w 1939 r. Narodny Albom stanowi więc swoistą furtkę do świata, któremu kres położyła II wojna światowa. Pomimo że każda postać i jej historia zostały wymyślone, to rock-opera (szczególnie jej odnowiona w 2016 r. wersja ${ }^{6}$ ) poprzez teksty piosenek, muzykę, kostiumy oraz scenografię niezwykle trafnie oddaje realia życia na Białorusi Zachodniej.

${ }^{4}$ M. Aniempadystau, L. Wolski, Narodny Albom, tłum. A. Wawrzeniuk, M. Wawrzeniuk, Białystok 2000, s. 15.

${ }^{5}$ KOP - Korpus Ochrony Pogranicza.

${ }^{6}$ M. Chołodowski, M. Żmijewska, Narodny Albom. Reaktywacja. I nostalgiczny powrót na pogranicze, 9.09.2016, http://bialystok.wyborcza.pl/bialystok/1,87318,20671076, naro dny-albom-reaktywacja-i-nostalgiczny-powrot-na-pogranicze.html [dostęp: 22.05.2021].

7 Poniższa analiza dotyczy pełnego scenariusza Narodnego Albumu oraz koncertu, który odbył się w Operze i Filharmonii Podlaskiej w Białymstoku 4 września 2016 r. Zapis 
Widowisko rozpoczyna pięciominutowy film wprowadzający. Na początku streszcza on historię powstania Narodnego Albomu, a następnie osadza w kontekście historycznym wydarzenia, o których za chwilę będą śpiewać muzycy. Jako pierwsze wspominane jest dojście bolszewików do władzy, które stało się możliwe dzięki rewolucji lutowej (1917) i październikowej (1918) ${ }^{8}$. Później archiwalne zdjęcia przenoszą zebranych w czasy wojny polsko-bolszewickiej (1920) oraz zwycięskiej dla polskiej strony Bitwy Warszawskiej. Dalej wzmiankowane jest podpisanie traktatu pokojowego pomiędzy obiema stronami w $1921 \mathrm{r}$. Podział ziem białoruskich obrazuje na ekranie mapa, efektowanie rozrywająca się na pół. Ostatnimi „wyświetlanymi” wydarzeniami jest wybuch II wojny światowej oraz wkroczenie 17 września 1939 r. Armii Czerwonej na terytorium II RP. Należy zaznaczyć, że rock-opera, m.in. poprzez piosenkę Pod uciskiem panów ${ }^{9}$, w ironiczny sposób polemizuje z sowieckim mitem szczęśliwego wyzwolenia białoruskich chłopów spod jarzma polskich panów. W tekście i fabule Narodnego Albomu można odszukać i inne nawiązania do ówczesnego życia na Białorusi Zachodniej, np. sytuacji społeczno-gospodarczej. Po trwających od 1914 do 1921 r. wojnach przyłączone do II RP białoruskie ziemie były bardzo zniszczone i zaniedbane. Gospodarka była w fatalnym stanie. Polski rząd nie miał jednak wystarczającej ilości środków finansowych, żeby rozpocząć szybką odbudowę i modernizację tych terenów. W rezultacie wschodnie województwa należały do najbiedniejszych ziem w granicach II Rzeczypospolitej. Tylko $1 / 3$ gospodarstw chłopskich była $w$ stanie wyżywić ich właścicieli ${ }^{10}$. Bieda panuje i w chałupie Kostków. Sam pan wie, jak mi się wiedzie, nie powiem żeby bardzo słodko ${ }^{11}$ - narzeka Bronisława, łatając domowy budżet na wszelki możliwy sposób: sprzedając rodową biżuterię czy zbierając grzyby. W związku z biedą i brakiem perspektyw wielu Białorusinów, w poszukiwaniu godnych zarobków oraz lepszego życia, decydowało się na emigrację. Taką możliwość rozważa i Zmicier, który zastanawia się nad wyjazdem do Estonii lub Hiszpanii. Trudna sytuacja ekonomiczna w połączeniu z wysokimi cenami towarów po sowieckiej stronie granicy sprzyjała rozwojowi kontrabandy. Do Związku Radzieckiego

koncertu pt. Нароgны альбом. 20 гаgоў: https://www.youtube.com/watch?v=NwYrSUOqzSU [dostęp: 22.05.2021].

${ }^{8}$ W wyniku rewolucji lutowej z 1917 roku w Rosji obalono carat. Nastały wówczas okres dwuwładzy (Rząd Tymczasowy, Piotrogrodzka Rada Delegatów Robotniczych i Żołnierskich), który zakończyła rewolucja październikowa w 1918 r.

9 М. Анемпадыстаў, Паg прыгнётам панскім.

10 Z. Szybieka, Historia Białorusi 1795-2000, tłum. H. Łaszkiewicz, Lublin 2002, s. 298.

${ }^{11}$ M. Aniempadystau, L. Wolski, Narodny Albom, s. 45. 
przerzucano wszystko: jedzenie, przedmioty codziennego użytku, walutę (dolary). Z sowieckiej Rosji sprowadzano zaś tytoń i herbatę. Za stolicę przemytników w międzywojennej Polsce uważany był przygraniczny Raków - miasteczko, w którym toczy się akcja Narodnego Albomu i po którym po kryjomu przemykają przemytnicy (Kontrabandzista ${ }^{12}$ ). Leśne, przygranicze ścieżki cieszyły się też zainteresowaniem szpiegów. Od 1918 r. w II RP powoli zaczął rozwijać się kontrwywiad. Zbierano informacje m.in. o Związku Radzieckim. Początkowo szpiedzy mieli dość małe doświadczenie. Świetnie oddają to postaci Bolka i Lolka, których tajna działalność nie stanowi jakiejkolwiek tajemnicy dla reszty lokalnej społeczności (Dwaj polscy szpiedzy³).

Teksty piosenek idealnie wspomaga ich muzyczna aranżacja. Różnojęzyczne utwory są chyba najlepszym sposobem pomagającym przekazać słuchaczom narodową i kulturową mozaikę polsko-sowieckiego pogranicza. Podczas spektaklu muzycznego można usłyszeć języki: białoruski (Adelka ${ }^{14}$ ), polski (Ja śpiewam po polsku $\left.{ }^{15}\right)$, rosyjski (Raz-dwa lewa ${ }^{16}$ ), jidysz (Loxmir zix iberbetn ${ }^{17}$ ) oraz niemiecki (Ein, zwei, $\left.d r e^{i 8}\right)$. Równie dobrze i oryginalnie wzajemne przeplatanie się kultur odwzorowuje różnorodność stylistyczna wykonywanych piosenek. Na Narodny Albom składają się: pieśni biesiadne (Młode piwo ${ }^{19}$ ), marsze wojskowe (Raz-dwa lewa), sentymentalne ballady (Grudzień, styczeń, luty20), eksperymentalny rap (Profesor Rahojsza ${ }^{21}$ ), piosenki ludowe (Nadzieńka ${ }^{22}$ ), żywe argentyńskie tango (Argentyńskie tango ${ }^{23}$ ) oraz skoczna polka (Krewska polka ${ }^{24}$ ).

W przybliżeniu klimatu międzywojennego, wielokulturowego miasteczka pomagają kostiumy wykonawców. W trakcie spektaklu muzycznego widz może zobaczyć: tradycyjny strój żydowski (złożony z czarnych zwężanych spodni, białej koszuli, czarnej kamizelki oraz jarmułki), białoruską wyszywankę (strój złożony z białej koszuli z ludowymi, wyszywanymi ornamentami, a także materiałowego

\footnotetext{
12 М. Анемпадыстаў, Кантрабандыст.

13 М. Анемпадыстаў, Два польскіх шпіёны.

14 М. Анемпадыстаў, Аgэлька.

15 М. Анемпадыстаў, Ja śpiewam po polsku.

16 М. Анемпадыстаў, Ать-gва левой.

17 Словы невядомага аўтара, Давай памірымся.

18 М. Анемпадыстаў, Айнц, цвай, gрай.

19 М. Анемпадыстаў, Малоgое піва.

20 М. Анемпадыстаў, Снежань, стуgзень, люты.

21 М. Анемпадыстаў, Настаўнік Рагойша.

22 Словы невядомага аўтара, Наgзенька.

23 М. Анемпадыстаў, Аргентынскае танга.

24 М. Анемпадыстаў, Крэўская полька.
} 
paska i Inianych spodni), polski mundur wojskowy z czasów II RP (skompletowany z szarej kurtki zapinanej na pięć guzików, bryczesów, wysokich cholew czarnego koloru i czapki) czy mundur czerwonoarmisty (składający się z zielonego, długiego płaszcza, zielonych spodni, a także słynnego filcowego okrycia głowy nazywanego bogatyrką lub budionówką). Międzywojenny styl obrazują też stroje damskie, np. kobiecy, trzyosobowy chórek prezentuje modę z lat 20. Zgodnie z ówczesnymi trendami panie mają na sobie wygodne sukienki o prostych fasonach, kończące się przed łydkami lub kolanami. Typową dla tamtego okresu jest szczególnie suknia z: krótkim nieodcinanym rękawkiem, dekoltem karo (podkreślonym białą lamówką, przechodzącą w ozdobny biały pasek), drapowaniem poniżej talii podkreślającym obniżoną talię oraz asymetrycznie umieszczoną kokardą. Całości dopełniają charakterystyczne krótkie, ciemne fryzury, schowane pod małymi kapelusikami oraz wyrazisty makijaż (mocna oprawa oczu, wyeksponowane, karminowe usta). Z kolei Kasia Kamockaja i Weronika Kruglowa przybliżają wygląd damskiego ubioru z lat 30. Ich długie wieczorowe suknie uzupełniają modne wówczas dodatki: sznury z pereł, rękawiczki oraz etole futrzane.

Ostatnim elementem osadzającym całe widowisko w latach 20. i 30. na Zachodniej Białorusi jest dokładnie przemyślana scenografia, wprowadzona w 2016 r. Podczas koncertu na scenie białostockiej opery pojawiły się: czarno-żółty słup pograniczny, szlaban oraz drewniany stół biesiadny. Za muzykami znajdował się natomiast duży telebim, na którym wyświetlano animacje pasujące do tematyki śpiewanego w danym momencie utworu. Przykładowo w czasie piosenek biesiadnych wyświetlano wnętrze karczmy (ogromnej wielkości półkę z różnymi trunkami). Ważną rolę pełnili także pomocnicy, m.in.: tancerze, którzy zaprezentowali ogniste tango, efektownie zatańczone na stole oraz statyści, którzy podczas marszy wojskowych maszerowali przebrani za czerwonoarmistów wokół sceny, skąpanej w złowieszczych, krwistoczerwonych barwach.

\section{Klip muzyczny jako krótki filmik historyczny}

Zbliżonym do koncertów muzycznych sposobem opowiadania dziejów Białorusi są wideoklipy. Dają one artystom praktycznie nieograniczone możliwości odwzorowywania rodzimej historii. O ile dość trudno sobie wyobrazić, aby zespoły w trakcie występów odtwarzały przykładowo przebieg jakiejś bitwy, o tyle teledysk już im taką możliwość daje. Grupy chętnie ten potencjał wykorzystują, albo posługując się gotowymi materiałami audiowizualnymi, np. kronikami, albo specjalnie nagrywając rekonstrukcje wydarzeń, o których śpiewają. Tworzą w ten 
sposób ze swoich klipów krótkie filmy historyczne. Za przykład może posłużyć Litwin / Літвін ${ }^{25}$ nagrany przez Starego Olsę. Specjalnie na potrzeby teledysku zrekonstruowano i sfilmowano przebieg bitwy pod Grunwaldem. W rezultacie oglądająca teledysk osoba otrzymuje rzeczywisty obraz wydarzeń. Akcja rozpoczyna się wraz z wyruszeniem w drogę małego zastępu rycerzy w celu dołączenia do reszty wojska Wielkiego Księstwa Litewskiego. Wędrujący przez lasy i polany wojownicy prezentują swój wygląd i uzbrojenie. W zależności od statusu oraz zamożności ubrani są: w koszulki kolcze, gacze ${ }^{26}$ składające się z 20-30 tysięcy metalowych kółeczek (do których przytwierdzano płytowe nagolenniki bądź nałokietniki) lub zbroję płytkową pokrywającą głowę, korpus, ręce i nogi. Na uzbrojenie ochronne niektórzy bohaterowie klipu mają nałożone dodatkowo dwuwarstwowe tuniki rycerskie koloru bordowego. Istotnym elementem ich wyposażenia są również trójkątne, czerwone tarcze z białym, dwuramiennym krzyżem. Następnie rycerze ukazani są już na placu boju. Po dwóch salwach z bombard ${ }^{27}$, ustawieni w szyku kolumnowym podzielonym na kilka szeregów, wojownicy WKL zrywają się do ataku na przeciwników - Krzyżaków. W Litwinie demonstrowane są dwa sposoby uderzenia: zwartej piechoty i ciężkiej konnicy rycerskiej. W obu przypadkach rycerze wspólnie ruszają do boju, aby po chwili brać udział w serii pojedynków. Piechota posługuje się mieczami obusiecznymi, a kawalerzyści kilkumetrowymi kopiami. Innymi wojennymi narzędziami wykorzystywanymi w czasie walki, które można zobaczyć w wideoklipie, są: sulica, czyli rodzaj włóczni służącej do zadawania uderzeń, młoty i topory rycerskie, siekiery bojowe oraz halabardy ${ }^{28}$.

Uzbrojenie Krzyżaków jest bardzo podobne, właściwie to od Rusinów i Litwinów odróżniają ich tylko charakterystyczne białe tuniki z czarnymi krzyżami. Obie strony biją się zawzięcie. Nastrój podbudowują animowane płomienie oraz błyskawice „przerywające” sceny walki. Wraz z upływem czasu przewagę zyskują wojska WKL, ścigające po leśnych zaroślach nielicznych już rycerzy teutońskich. Pod koniec teledysku zwycięzcy modlą się za poległych w walce. Na wideoklip składają się jednak nie tylko sceny z rekonstrukcji bitwy. Przeplatają je m.in. ujęcia muzyków grających w różnych miejscach: na leśnej

${ }^{25}$ Стары Ольса, Літвін, https://www.youtube.com/watch?v=FLxS2rE44Zo [dostęp: 22.05.2021].

26 Nazwa kolczugi w Wielkim Księstwie Litewskim. Spotykane są też inne określenia, np. „gace” lub „gacie”.

27 Bombarda - prototyp armaty.

28 Halabarda - dwuręczna broń drzewcowa złożona z siekiery, grota i haka używana przez piechotę. 
ścieżce, przy ognisku lub na placu walki. W rezultacie członkowie Starego Olsy, wzorem dawnych kapel wojskowych, towarzyszą rycerzom na każdym etapie życia obozowego - przypominając jednocześnie, jak ważną rolę pełnili muzycy w średniowiecznej infrastrukturze wojskowej: pomagali chociażby kierować wojskiem poprzez granie odpowiednich melodii do ataku czy odwrotu ${ }^{29}$. Również w teledysku, po sygnale z bębnów, trąb i rogów, rycerze WKL rzucają się w wir działań wojennych. Kadry walki i przygrywającego zespołu dopełniają miniatury z kronik albo powiększone fragmenty obrazów przedstawiające walczących rycerzy lub kapele wojskowe.

\section{Projekt muzyczny jako lekcja historii Białorusi}

Osobną uwagę warto zwrócić na wspólne projekty muzyczne, zrzeszające wokół idei popularyzacji mniej znanej historii Białorusi największe gwiazdy białoruskiej sceny alternatywnej. Początkowo inicjatywy łączące różnych wykonawców sprowadzały się do nagrywania zbiorowych albumów, np. Narodny Albom / Нароgны Альбом (1997) сzy Urodziłem się tutaj / я нараgзіўся тут (2000). Postęp technologiczny, rozwój środków przekazu - zwłaszcza mediów społecznościowych - jak również finansowanie społecznościowe (ang. crowdfunding) spowodowały, że przedsięwzięcia artystów zyskały nowe możliwości i nabrały całkiem innego charakteru.

Najlepszym tego przykładem jest projekt (Nie)rozstrzelana poezja / ( $\mathrm{He}$ ) расстраляная паезія z 2017 r. Jego pomysłodawcą był założyciel portalu muzycznego Tuzinfm.by, Siarhiej Budkin ${ }^{30}$. Znany i ceniony krytyk chciał przypomnieć o przypadającej 29 października 2017 r. osiemdziesiątej rocznicy tzw. Czarnej Nocy, kiedy to funkcjonariusze NKWD rozstrzelali stu trzydziestu przedstawicieli białoruskiej inteligencji31. Około trzydziestu z nich należało do środowiska literackiego ${ }^{32}$. Niestety, był to dopiero początek krwawych lat Wielkiego terroru. Ogółem szacuje się, że w latach 1930-1939 prześladowaniami objęto około 350 białoruskich literatów, z czego prawie połowie z nich odebrano

29 Zob. więcej 3. Сасноўскі, Музычная культура рыцарскага саслоўя Вялікага Княства Літоўскага і Каралеўства Польскага, Мінск 2010.

30 (Не)Расстраляная паэзія. Прэмера музычнага праекту і курсу віgэалекцыяў пра паэтаў 1930-х (аўgыё+віgэа), 27.10.2017, http://tuzinfm.by/article/3996/nierasstralanajapaezija-premjera-muzycnaha-prajektu.html [dostęp: 22.05.2021].

31 Ibidem.

32 Ibidem. 
życie ${ }^{33}$. Mordowano przede wszystkim najzdolniejszych poetów i prozaików białoruskiego odrodzenia kulturalnego lat 20. XX wieku, którzy dopiero osiągali swoje pierwsze literackie sukcesy. Komunistyczne władze zadbały o to, aby wymazać z pamięci społeczeństwa nie tylko ich nazwiska, lecz także ich twórczość. Podczas zatrzymań specjalni eksperci literaccy NKWD przeszukiwali mieszkania, zabierali i niszczyli później wszystkie książki czy rękopisy, które nie odpowiadały ideologicznym wymaganiom ${ }^{34}$. Wszystkich rozstrzelanych zrehabilitowano w czasie odwilży Chruszczowa. Niemniej współczesna białoruska władza, bardzo niechętnie odnosząca się do podejmowania tematu stalinowskich represji, dopełniła komunistycznego dzieła zapomnienia. W rezultacie Siarhiej Budkin, kiedy po raz pierwszy zobaczył nazwiska ofiar Czarnej Nocy, zorientował się, że nic mu one nie mówią. Zaczął więc szukać jakichkolwiek informacji na temat rozstrzelanych. Znalazł ich niewiele, a większość pochodziła z rodzinnych archiwów. Wtedy to białoruski krytyk muzyczny wpadł na pomysł zorganizowania szeroko zakrojonego przedsięwzięcia, wskrzeszającego zapomnianych i przywracającego im należyte miejsce w białoruskiej kulturze. Do współpracy zaprosił czołowe białoruskojęzyczne zespoły, a także historyków, literaturoznawców, kulturoznawców, reżyserów, aktorów, grafików i dziennikarzy.

Dotychczas czegoś takiego nie było. Najważniejsze jest, by przypomnieć o tych ludziach, tak by nie znikli z pamięci. W naszym kraju ofiarom nazizmu okazuje się bardzo wiele uwagi i to jest prawidłowe, jednak jeżeli chodzi o ofiary stalinizmu, to na nich zamyka się oczy. W dzisiejszym KGB siedzą ideologiczni i duchowi potomkowie tych ludzi, którzy rozstrzeliwali w latach 30. I jest to jedna z przyczyn, że dziś nie jest popularny temat Kuropat, wspominanie tych ofiar. Jednak o nich trzeba mówić, jeśli nie każdego dnia, to przy pomocy tego typu projektów ${ }^{35}$,

tłumaczył Aleś Dzianisau, jeden z pierwszych muzyków, który zgodził się wziąć udział w wydarzeniu. W (Nie)rozstrzelanej poezji wzięli również udział: Kaciaryna Wadanasawa (fantasy-rock), Lawon Wolski (rock), Paweł Arakielan (jazz), śpie-

33 W. Uładzimirauna, Faszystowski spisek poetów. Co wymyślało NKWD, by wymordować białoruskq̨ inteligencje, 1.08.2018, https://belsat.eu/pl/news/sfabrykowane-dowody-brutalne-tortury-jak-stalin-niszczyl-bialoruska-inteligencje-cz-1/ [dostęp: 22.05.2021].

34 Ibidem.

35 J. Biernat, „(Nie) rozstrzelana poezja”. Białoruscy muzycy nagrają album do tekstów poetów zabitych przez NKWD, 24.04.2017, https://belsat.eu/pl/news/nie-rozstrzelanapoezja-bialoruscy-muzycy-nagraja-album-do-tekstow-poetow-rozstrzelanych-przez-nkwd/ [dostęp: 22.05.2021]. 
waczka Swieta Bień, Vinsent (rap), bard Zmicier Wajciuszkiewicz oraz zespoły: Akute (indie-rock), Naka (dramatic-rock), Re1ikt (post-metal z domieszką folku), TonqiXod (intelektualny rock) i Vuraj (folk) ${ }^{36}$. Artyści wybrali po jednym poecie z lat 20. i 30. XX wieku, a następnie skomponowali do wybranego wiersza muzykę ${ }^{37}$. Każdy z wykonawców, w charakterystyczny dla swojej twórczości sposób, oddał radość, rozpacz, zwątpienie i wiarę w lepsze jutro, którymi przesiąknięte są dzieła białoruskich literatów.

Gdy wszyscy muzycy nagrali już swoje aranżacje piosenek i zamieszczono je w internecie, rozpoczął się drugi etap inicjatywy Budkina. Od 1 września do połowy listopada 2017 r. zorganizowano dwanaście otwartych wykładów ${ }^{38}$. Spotkania odbywały się co tydzień w mińskiej księgarni Łohwinów. Prowadzili je znawcy białoruskiej literatury: Andriej Chadanowicz, Wolf Rubinczyk, Anatol Rudak, Hanna Siewiaryniec, Aliaksiej Strelnikaŭ i Wiktar Żybul39. Każdy wykład rozpoczynał się krótkim wprowadzeniem w epokę. Zebranym pokrótce przybliżano sytuację, w jakiej znajdowała się kultura białoruska w latach 20. i 30. XX wieku w BSRR. Następnie omawiano główne tendencje ówczesnej literatury: nurty, stowarzyszenia i najważniejsze dzieła. Potem przechodzono do prezentacji życiorysu danego poety i jego twórczości. Lekcje kończyły się kameralnymi występami muzyków biorących udział w projekcie. Aby jak najbardziej rozpowszechnić informacje o spotkaniach w mediach społecznościowych, przeprowadzono kampanię, która równocześnie miała pomóc w zebraniu środków finansowych potrzebnych do dalszej realizacji projektu. W tym celu reżyser Arciom Łobacz nakręcił poruszający klip promocyjny ${ }^{40}$.

36 Розныя артысты, «(Не)расстраляная паэзия» (+аўgыё), 15.11.2017, https://www. experty.by/content/roznyya-artysty-nerasstralyanaya-paeziya-audyjo [dostęp: 22.05.2021].

37 Akute - Pokochałem Ciebie Anatola Wolnego (1902-1937), Vuraj - Nastrój Jurki Lawonnego (1908-1937), Zmicier Wajciuszkiewicz - Przeszłość Uładzisłaua Hałubka (18821937), Lawon Wolski - Ty pamiętasz Julija Taubina (1911-1937), Vinsent - Metropolian, Ziamy Piwawarawa (1910-1937), Dzieciuki - Buntownik Michasia Czarota (1896-1937), Kaciaryna Wadanasawa - Osypuje czerwień biały sad Alesia Dudara (1904-1937), Paweł Arakielan - Hultaj Majseja Kulbaka (1896-1937), Re1ikt - O czarnych oczach Michasia Zareckiego (1901-1937), Naka - Tym, którzy odeszli Waleryja Marakowa (1909-1937), TonqiXod - Mknący pociąg Todara Klasztornego (1903-1937), Swietłana Beń - W szarym zmroku Izi Charyka (1896-1937).

38 (Не) Расстраляная паэзія.

39 Ibidem.

40 А. Лобач, Прома-віgэа gа музычнага праекту „(Не) расстраляная паэзія”, 20.04.2017, https://www.youtube.com/watch?v=sXMzX2Zcq5w [dostęp: 22.05.2021]. 
W postaci poetów młodego pokolenia, przepełnionych marzeniami i planami na przyszłość, wcielili się Pawał Charłanczuk i Andriej Sauczanka. W krótkim filmiku wystąpiła też Alena Hiranok, grająca pannę młodą szykującą się do ślubu. Ubrana już na biało kobieta, w ostatniej chwili dowiaduje się o śmierci swojego narzeczonego. Klip kończy się hasłem: Musimy o nich pamiętać, żeby samemu nie zniknąć. Równocześnie w sieci pojawiło się dwanaście czarno-białych filmików - apeli uczestników projektu, wzywających do zwrócenia uwagi na ofiary Czarnej Nocy ${ }^{41}$. Można w nich usłyszeć m.in.: to nasi bohaterowie; wiersze tych poetów stały się częścia historii naszej ojczyzny czy: niestety nie możemy zmienić naszej historii, ale musimy znać jej krwawa spuściznę i modlić się za tych ludził2. Organizatorzy projektu (Nie)rozstrzelana poezja pomyśleli też o osobach, które z różnych przyczyn nie mogły przybyć na wykłady. Specjalnie dla nich nagrywano je, a następnie umieszczano na założonych wcześniej na Facebooku profilach poetów ${ }^{43}$. Na profilach tych umieszczano też informacje z życia danego twórcy, jego dzieła oraz materiały dotyczące białoruskiej kultury lat 20. i 30. XX wieku44.

Ukoronowaniem całej inicjatywy był uroczysty koncert, który odbył się w 80. rocznicę Czarnej Nocy - 29 października 2017 r. Zaprezentowano nagrane wcześniej muzyczne aranżacje rozstrzelanych poetów. Występ transmitowano on-line na kanale Tuzin.fm ${ }^{45}$. Podczas wydarzenia można było kupić „milczące księgi", czyli notatniki z podobiznami i cytatami literatów. Natomiast dzień po

41 Вigэазварот уязельнікаў музычнага праекту „(Не) расстраляная паэзія”, 27.06.2017, https://www.youtube.com/watch?v=IMV_8ZO5gNs [dostęp: 22.05.2021].

42 Ibidem, tłum własne.

43 Nagrania wszystkich, dwunastu wykładów, które odbyły się w ramach projektu (Nie)rozstrzelana роеzја: Аgкрытая лекцыя Анgрэя Хаgановіча (+новая песьня Лявона Вольскага), https://www.youtube.com/watch?v=xYR1TCOvxtw\&list=PL-W4XNs4lTJ1rpMurngB9pz75Qb19tvyl [dostęp: 22.05.2021].

44 Profile poetów na Facebooku: Michaś Czarot https://www.facebook.com/mihascharot, Anatol Wolny https://www.facebook.com/anatolvolny, Jurka Lawonny https:// www.facebook.com/jurkaliavonny/, Majsej Kulbak https://www.facebook.com/majsejkulbak, Michaś Zarecki https://www.facebook.com/mihaszarecki, Zima Piwawarau https:// www.facebook.com/ziamapivavarau/, Uladzislau Galubok https://www.facebook.com/ uladzislaugalubok, Julij Taubin https://www.facebook.com/julitaubin, Izi Charyk https:// www.facebook.com/iziharyk, Walery Marakou https://www.facebook.com/valerymarakou, Todar Klasztorny https://www.facebook.com/todarkliashtorny, Aleś Dudar https://www. facebook.com/alesdudar.

45 Zapis koncertu (Nie)rozstrzelana poezja, 29.10.2017, https://www.youtube.com/ watch?v=F1_fjqveEZk\&list=PL-W4XNs4ITJ3Rs83rCzql5HpLezwsb3jh [dostęp: 22.05.2021]. 
koncercie miała miejsce premiera albumu (Nie)rozstrzelana poezja ${ }^{46}$. Początkowo, zgodnie z założeniem Siarhieja Budkina, projekt miał się skończyć wraz z ostatnim wykładem, czyli 16 listopada 2017 r. Jednak ze względu na ogromne zainteresowanie przedsięwzięciem postanowiono je kontynuować. We wrześniu 2018 r. ruszyła kolejna internetowa zbiórka pieniędzy. Tym razem pozyskane fundusze przeznaczono na wydanie pierwszej książki poświęconej rozstrzelanym poetom. Z tej okazji opublikowano kolejny klip promocyjny ${ }^{47}$. Książka ukazała się 15 lutego 2021 r. i zawiera: 18 życiorysów poetów, 100 zdjęć, 100 utworów oraz płytę CD z aranżacją muzyczną wierszy ${ }^{48}$.

Przykład (Nie)rozstrzelanej poezji pokazuje, jak projekty muzyczne można przeobrazić w wieloaspektowe lekcje historii. Kameralnym występom muzyków mogą towarzyszyć wykłady specjalistów - w tym przypadku literaturoznawców - wprowadzające w daną epokę, o której będą za chwilę śpiewać artyści. Nowe technologie umożliwiają zaś nagrywane takich spotkań oraz późniejsze umieszczane ich w internecie, na specjalnych stronach czy ogólnodostępnych kontach w mediach społecznościowych: Facebook i YouTube. Co istotne, oprócz nagrań można na nich zamieszczać też inne dodatkowe materiały poszerzające wiedzę. Dzięki temu powstają swoiste platformy edukacyjne, do których dostęp ma każdy, w dowolnych: chwili i miejscu na ziemi.

\section{Zakończenie}

Reasumując, można stwierdzić, iż współczesna kultura muzyczna Białorusi stanowi bogate źródło alternatywnej wiedzy na temat dziejów kraju i ponad wszelką wątpliwość może być stosowana do popularyzacji rodzimej historii. Przedstawiona w niniejszej pracy problematyka nie wyczerpuje jednak zagadnienia w całości. Nieustanny rozwój techniki, środków rozpowszechniania, przy jednoczesnym stałym pojawianiu się nowych gatunków muzycznych, zespołów i pomysłów muzyków sprawiają, że kwestia wykorzystywania kultury muzycznej

46 Pojawił się długo oczekiwany album „(Nie)rozstrzelana poezja”, 27.10.2017 https:// belsat.eu/pl/news/pojawil-sie-dlugo-oczekiwany-album-nie-rozstrzelana-poezja/ [dostęp: 22.05.2021].

47 А. Лобач, (Не)расстраляная паезія. Працяг, https://www.youtube.com/watch?v= W5JV4qRoAbc [dostęp: 22.05.2021].

48 У выgавецтве «Янушкевіч» выйшла грунтоўная кніга пра расстраляных у 1937 гоgзе беларускіх літаратараў, 12.02.2021, https://nashaniva.com/?c=ar\&i=268265 [dostęp: 28.08.2021]. 
do szerzenia niezależnej wiedzy historycznej pozostaje otwarta i wymaga dalszych badań. Podobnie zresztą, jak problem posługiwania się w tym celu innymi dziedzinami kultury i sztuki, np. filmami.

\section{Bibliografia}

Adkrytaâ lekcyâ Andrèâ Hadanoviča (+novaâ pes'nâ Lâvona Vol'skaga) [Аgкрытая лекцыя Андрэя Хаgановіча (+новая песьня Лявона Вольскаг а)], https://www. youtube.com/watch?v=xYR1TCOvxtw\&list=PL-W4XNs4lTJ1rpMurngB9pz75Qb19tvyl [dostęp: 22.05.2021].

Aniempadystau M., Wolski L., Narodny Albom, tłum. A. Wawrzeniuk, M. Wawrzeniuk, Białystok 2000.

Biernat J., „Dzieciuki” - białoruscy punkowcy zakochani w powstańcach styczniowych, 1.05.2013, https://belsat.eu/pl/news/13752/ [dostęp: 22.05.2021].

Biernat J., ,(Nie)rozstrzelana poezja”: białoruscy muzycy nagrają album do tekstów poetów zabitych przez NKWD, 24.04.2017, https://belsat.eu/pl/news/nie-rozstrzelana-poezjabialoruscy-muzycy-nagraja-album-do-tekstow-poetow-rozstrzelanych-przez-nkwd/ [dostęp: 22.05.2021].

Chołodowski M., Żmijewska M., Narodny Albom. Reaktywacja. I nostalgiczny powrót na pogranicze, 9.09.2016, http://bialystok.wyborcza.pl/bialystok/1,87318,20671076, naro dny-albom-reaktywacja-i-nostalgiczny-powrot-na-pogranicze.html [dostęp: 22.05.2021].

Koźmińska M.J., Elementy pamięci historycznej we współczesnej kulturze muzycznej Białorusi, 2019 [praca magisterska].

Lobač A., Proma-vidèa da muzyčnaga praektu „(Ne) rasstralânaâ paèziầ" [Лобач A., Промавіgэа gа музычнага праекту „(Не) расстраляная паэзія”], https://www.youtube.com/ watch?v=sXMzx2Zcq5w [dostęp: 22.05.2021].

(Ne)Rasstralânaâ paèziâ. Prèm'era muzyčnaga praektu i kursu vidèalekcyâǔ pra paètaǔ 1930-h (aǔdyë+vidèa) [(Не)Расстраляная паэзія. Прэм'ера музычнага праекту і курсу віgэалекцыяў пра паэтаў 1930-х (аўgыё+віgэа)], 27.10.2017, http://tuzinfm.by/article/3996/nierasstralanaja-paezija-premjera-muzycnaha-prajektu.html [dostęp: 22.05.2021].

Pojawił się długo oczekiwany album „(Nie)rozstrzelana poezja”, 27.10.2017, https://belsat.eu/pl/ news/pojawil-sie-dlugo-oczekiwany-album-nie-rozstrzelana-poezja/ [dostęp: 22.05.2021]. Roznyâ artysty, „(Ne)rasstralânaâ paèziâ" (+aǔdyë) [Розныя артысты, „(Не)расстраляная паэзия" (+аўgыё)], 15.11.2017, https://www.experty.by/content/roznyya-artysty-nerasstralyanaya-paeziya-audyjo [dostęp: 22.05.2021].

Sasnoǔskì Z., Muzyčnaâ kul'tura rycarskaga sasloǔâ Vâlikaga Knâstva Litoǔskaga ì Karaleǔstva Pol'skaga, Mìnsk 2010 [Сасноўскі 3., Музычная культура рыцарскага саслоўя Вялікага Княства Літоўскага і Каралеўства Польскага, Мінск 2010].

Stary Olsa, Litwin [Літвін], https://www.youtube.com/watch?v=FLxS2rE44Zo [dostęp: 22.05.2021]. 
Szybieka Z., Historia Białorusi 1795-2000, tłum. H. Łaszkiewicz, Lublin 2002.

Uładzimirauna W., Faszystowski spisek poetów. Co wymyślało NKWD, by wymordować białoruską inteligencje, 1.08.2018, https://belsat.eu/pl/news/sfabrykowane-dowodybrutalne-tortury-jak-stalin-niszczyl-bialoruska-inteligencje-cz-1/ [dostęp: 22.05.2021].

U vydavectve „Ânuškevič” vyjšla gruntoŭnaja kniha pra rasstralânych u 1937 godze belaruskih litarataraŭ [У выgавецтве „Янушкевіч” выйшла грунтоўная кніга пра расстраляных у 1937 гоgзе беларускіх літаратарау], 12.02.2021, https://nashaniva.com/?c=ar\&i=268265 [dostęp: 28.08.2021].

Vidèazvarot udzel'nikaǔ muzyčnaga praektu „(Ne) rasstralânaâ paèziâ” [Вigэазварот уgзельнікаў музычнага праекту „(Не) расстраляная паэзія”, 27.06.2017, https://www. youtube.com/watch?v=IMV_8ZO5gNs [dostęp: 22.05.2021].

Zapis koncertu Narodny Albom, 20 lat, https://www.youtube.com/watch?v=NwYrSUOqzSU [dostęp: 22.05.2021].

Zapis koncertu (Nie)rozstrzelana poezja, 29.10.2017, https://www.youtube.com/watch?v=F1_ fjqveEZk\&list=PL-W4XNs4ITJ3Rs83rCzql5HpLezwsb3jh [dostęp: 22.05.2021]. 


\section{Noty o autorach}

JOANNA GETKA - profesor doktor habilitowana, językoznawca i literaturoznawca. Kierownik Katedry Studiów Interkulturowych Europy Środkowo-Wschodniej Wydziału Lingwistyki Stosowanej Uniwersytetu Warszawskiego.

JERZY GRZYBOWSKI - doktor habilitowany, historyk. Pracuje w Katedrze Studiów Interkulturowych Europy Środkowo-Wschodniej Wydziału Lingwistyki Stosowanej Uniwersytetu Warszawskiego.

NATALLIA HARDZIYENKA - doktor, historyczka. Pracuje w Białoruskim Państwowym Archiwum Muzeum Literatury i Sztuki w Mińsku. Bada dzieje emigracji białoruskiej w XX w.

ALIAKSANDR HUZHALOUSKI - profesor doktor habilitowany, pracownik Katedry Muzealnictwa, Etnologii i Historii Sztuki na Wydziale Historycznym Białoruskiego Uniwersytetu Państwowego. Autor szeregu publikacji naukowych z zakresu historii kultury i historii społecznej Białorusi w XX w.

RADOSŁAW KALETA - doktor habilitowany, językoznawca. Kierownik Katedry Białorutenistyki Uniwersytetu Warszawskiego.

MARIANNA JULIA KOŹMIŃSKA - magister studiów nad słowiańszczyzną wschodnią Wydziału Lingwistyki Stosowanej Uniwersytetu Warszawskiego, obecnie studentka studiów podyplomowych Nowe media w instytucjach dziedzictwa kulturowego Wydziału Dziennikarstwa, Informacji i Bibliologii Uniwersytetu Warszawskiego. 
VIKTAR KORBUT - doktorant na Uniwersytecie Warszawskim. Zajmuje się historią piśmiennictwa białoruskiego na początku XX w. oraz kwestią kształtowania tożsamości białoruskiej.

ANTONI MIRONOWICZ - profesor doktor habilitowany, kierownik Pracowni Historii Europy Środkowo-Wschodniej Uniwersytetu w Białymstoku. Specjalizuje się w historii Kościoła wschodniego w Europie Środkowej i Wschodniej.

VIACHASLAU SHVED - profesor doktor habilitowany, pracuje w Katedrze Studiów Interkulturowych Europy Środkowo-Wschodniej Wydziału Lingwistyki Stosowanej Uniwersytetu Warszawskiego. Zainteresowania badawcze: rozwój gospodarczy Białorusi w pierwszej połowie XIX w., życie społeczne i polityczne na ziemiach białoruskich w latach 1772-1863, historia Grodna. Autor ponad 300 prac naukowych wydanych w kraju i za granica.

SIARHEY SHABELTSAU - doktor, historyk. Pracuje na Europejskim Uniwersytecie Humanistycznym w Wilnie. Zainteresowania badawcze: dzieje diaspory białoruskiej w Ameryce Południowej w XX w. 
Pomimo bliskiego sąsiedztwa wiedza społeczeństwa polskiego o Białorusinach i Białorusi nadal jest dość powierzchowna i fragmentaryczna. Polacy utożsamiają ten kraj z ostatnią dyktaturą Europy, niewiele zaś wiedzą o jego tradycjach i aspiracjach niepodległościowych. Niniejsza monografia zbiorowa ma na celu przybliżenie czytelnikowi uwarunkowań społeczno-politycznych i cywilizacyjno-kulturowych kształtowania się białoruskiej tożsamości narodowej na przestrzeni wieków. Pokazuje również główne problemy, z którymi mierzą się Białorusini w poszukiwaniu drogi własnego rozwoju cywilizacyjnego na pograniczu kultur szeroko rozumianego Wschodu i Zachodu. Książka jest pokłosiem wieloletnich badań prowadzonych w Polsce i za granicą przez międzynarodowe grono badaczy. Jej autorami są znawcy problematyki reprezentujący różne dyscypliny naukowe (historia, politologia, kulturoznawstwo, językoznawstwo), co pozwoliło naświetlić kwestię tożsamości Białorusinów w szerokiej perspektywie.

Joanna Getka, prof. dr hab., kierownik Katedry Studiów Interkulturowych Europy Środkowo-Wschodniej Uniwersytetu Warszawskiego (KSIEŚW UW), filolożka białorutenistka i rusycystka, kulturoznawczyni. Autorka monografii i artykułów z zakresu białoruskiej i ukraińskiej kultury piśmienniczej oraz kształtowania się nowoczesnej tożsamości kulturowej Białorusinów i Ukraińców.

Jerzy Grzybowski, dr hab., pracuje w Katedrze Studiów Interkulturowych Europy Środkowo-Wschodniej Uniwersytetu Warszawskiego (KSIEŚW UW). Historyk, zajmuje się historią polityczną i religijną oraz historią wojskowości Białorusi XX wieku. Autor monografii i artykułów z zakresu historii Białorusi i stosunków polsko-białoruskich, a także Kościoła prawosławnego w Polsce. 